\title{
Gênero e atenção à saúde: explorando o IDH e a variável sexo na morbidade hospitalar no SUS
}

\section{GILIANA BETINI}

\begin{abstract}
Tese apresentada ao
Programa de Pós-Graduação

em Saúde Pública da

faculdade de Saúde Pública da Universidade de São Paulo para obtenção do título de Doutor em Saúde Pública
\end{abstract}

Área de concentração: Saúde Materno Infantil

Orientador: PROF. DR.

Rubens de Camargo Ferreira

Adorno

\section{São Paulo}




$$
45943 / 2005 \text { do }
$$

Autorizo exclusivamente para fins acadêmicos, a reprodução total ou parcial desta dissertação, por processos fotocopiadores

Assinatura:

Data: 


\section{AGRADECIMENTOS}

Ao Rubens, pelo apoio e generosidade em compartir seu conhecimento e "sua casa", o que foi fundamental para que eu completasse esse percurso, apesar dos obstáculos.

Aos membros da banca, professoras Augusta Thereza de Alvarenga, Elizabeth Meloni Vieira, Márcia Furquim de Almeida e Maria José Martins Duarte Osis, pela paciência na leitura e nas sugestōes que possibilitaram melhorar a qualidade do trabalho.

A minha família e em especial a minha irmã Marluci, que ajudou no começo

e no fim do percurso, primeiro com o levantamento bibliográfico e depois com a revisão das citaçōes e referências.

Ao Denis Murahovschi e Camilo Mussi, que pela amizade, ainda que informal, deram o apoio institucional.

Aos amigos e amigas, de perto e de longe, que suportaram minhas crises e me apoiaram para que avançasse e completasse este percurso, que por vezes foi tortuoso, mas no fim, gratificante. 


\section{RESUMO}

Betini, Giliana. Gênero e Atenção à Saúde: explorando o IDH e a variável sexo na morbidade hospitalar no SUS. Săo Paulo; 2005. [Tese de Doutorado - Faculdade de Saúde Pública da USP].

Estudo comparativo do perfil da morbidade hospitalar com enfoque de gênero em seis Regiőes Metropolitanas, que foram selecionadas usando como recorte o Indice de Desenvolvimento Humano-IDH 2000. As Regiões escolhidas foram: a RM do Norte/Nordeste de Santa Catarina-Núcleo, RM de Campinas, RM de Porto Alegre, RM de Săo Luis, RM de Maceió e Colar Metropolitano do Vale do Aço. Como fonte de dados utilizamos o Sistema de Informação Hospitalar. Analisamos o perfil da morbidade de homens e mulheres de 15 a 49 anos. Verificamos que as maiores taxas de internação, financiadas pelo SUS, ocorrem nas RMs com pior IDH. Retiramos da análise as AlHs com diagnóstico de Gravidez, Parto e Puerpério (Cap.XV CID-10) e as de tipo 5. No total de AlHs analisadas, as mulheres apresentaram diferença significativa na taxa de Internação, em relação aos homens, nas RMs de São Luis e Maceió, enquanto que na RM de Campinas as internações masculinas foram superiores. Nas demais regiōes as diferenças nas taxas de internação não foram significativas para nenhum dos sexos. Exceto pela RM do N/NE de Santa Catarina, na qual a principal causa de internação foram as Neoplasias, nas demais RMs as Doenças do aparelho geniturinário foram a principal causa de internação feminina. Para os homens a principal causa de internação foram as Lesões envenenamentos e algumas outras conseqüências de causas externas, exceto na RM de Maceió, onde foram os Transtornos mentais e comportamentais. Encontramos diferenças nos perfis de morbidade com a utilização da variável sexo, que se acentuam ou ganham contornos quando relacionadas com as condições de vida e o nivel socioeconômico.

Descritores: Informação em saúde. Morbidade Hospitalar. Gênero 
SUMMARY

Betini, Giliana. Gender and Health Services: an introductory study about Human Development Index and gender in morbidity data from hospital in Public Health System; 2004. [PhD Thesis- Faculdade de Saúde Pública da Universidade de São Paulo Brasil].

To Compare morbidity about data from Public Hospitals in six metropolitan area in Brazil. The six metropolitan studied areas were chosen using the Human Development Index (HDI). These regions are: Metropolitan Area north/northest Santa Catarina State; Campinas; Porto Alegre, São Luis, Macéio and Vale do Aço Collar's metropolitan area. Using Hospital data from the Public Health System (SUS) we analyzed the group between 15 to 49 years old, considering morbidity and gender distribution. There are Hospital internments financed by the SUS in the Metropolitan Areas (MA) with worse HDI. For the population aged 15 to 49 the taxes of feminine internments are superior the masculines ones, however when we removed those related in chapter 15 of ICD 10, which corresponds to Pregnancy and birth, the taxes almost are equaled. In Campinas, the masculine internments exceeds the feminine ones. In the MA of São Luis and Maceió the women presented significant differences compared to men regarding the total hospital internments. While in the MA of Campinas masculine hospital internments here superior to the feminine ones. In others MA the differences in the internment taxes were not significants for none of the sexes. Except for the Metropolitan Area of the N/NE of Santa Catarina, in which the main causes of internment were the Neoplasia, in the others MA, the Illnesses of the genitourinary system were the main causes of feminine internments. For the men the main cause of internment were the Injury, poisoning and certain other consequences of external causes, except in the MA of Maceió, where they were Mental and behavioral disorders.

Descritores Information in health, Gender, Morbidity 


\section{Lista de Tabelas e Gráficos}

\section{Tabelas}

Tabela 1: Principais características dos Sistemas de Informação em Saúde. ....... 26

Tabela 2: Fluxo básico de autorização da internação hospitalar ............................ 31

Tabela 3 : IDHM91 e IDHM00 para as Regiões Metropolitanas selecionadas........69

Tabela 4: Participação da RM na população brasileira, participação da população do pólo na RM, população da RM, municipios sede e total de municipios. Regiōes Metropolitanas, 2002

Tabela 5:Razão de masculinidade para população total, menores de 1 ano e população de 15 a 49 anos. Regiões Metropolitanas, 2002 ..................... 72

Tabela 6: Razão de dependência e porcentagem da população de 15 a 49 anos. Regiōes Metropolitanas- 2002.

Tabela 7: Taxa especifica de fecundidade e Taxa de fecundidade geral (por mil mulheres da faixa etária). Regiões metropolitanas - 2001.

Tabela 8: Taxa de crescimento da população para os períodos 1991-2000, 20002001 e 2001-2002 nas Regiöes metropolitanas selecionadas........................ 81

Tabela 9: Taxa Bruta de mortalidade e taxa especifica por sexo. Regióes Metropolitanas. 2002

10: Taxa específica de mortalidade por idade (mil habitantes). Regiōes Metropolitanas, 2002

Metropolitanas, 2002....................................................................... Brasil e Regiões Metropolitanas. 2000.

alfabetismo da População de 15 Anos e Mais, por Sexo.

Tabela 12: Taxa de desemprego e massa de rendimento. Regiōes Metropolitanas. 2003.

Tabela 13: ICH, Renda per capita domiciliar e Rendimento médio de todos os trabalhos

Tabela 14: Taxa de estabelecimentos de saúde por 100 mil habitantes, segundo tipos de atendimento e Regiōes Metropolitanas. 2002

Tabela 15: Estabelecimentos de saúde com internação por esfera administrativa, segundo Regiōes Metropolitanas. 2002

Tabela 16 - Número de estabelecimentos de saúde por categoria e regime de atendimento, segundo Regiőes Metropolitanas. 2002.

Tabela 17: Taxa de equipamentos existentes em estabelecimentos de saúde por tipo e Regiōes Metropolitanas - 2002 (por 100000 habitantes)

Tabela 18:Taxa de Equipamentos existentes por habitantes, disponiveis ao SUS, em estabelecimentos de saúde, por tipo, segundo Regiōes Metropolitanas 2002 (por 100000 habitantes)

Tabela 19: Taxa de leitos para internação em estabelecimentos de saúde, por esfera administrativa, segundo Regiōes Metropolitanas. 2002. (por 1000 habitantes)

Tabela 20: Taxa de leitos, disponíveis para o SUS, para internação em estabelecimentos de saúde, segundo Regiões Metropolitanas. 2002. (por 1000 habitantes)

Tabela 21: Taxa de internaçăo financiada pelo SUS segundo Região Metropolitana. 2002. (por 100 mil habitantes) ..................................................................93

Tabela 22: Média de consultas SUS por 1000 habitantes.2002 ......................... 93

Tabela 23: Porcentagem da população assistida por planos e seguros privados de saúde suplementar, segundo Regiōes Metropolitanas. 2002 
Tabela 24: AlHs do grupo etário de 15 a 49 anos, por tipo e Regiōes Metropolitanas. 2002

Tabela 25: AlHs de tipo 1, por sexo e Regiões Metropolitanas. 2002 ....................96

Tabela 26: AlHs de tipo 5, por sexo e Regiões Metropolitanas. 2002 .................. 97

Tabela 27: Taxa de internação da população de 15 a 49, por Regiões Metropolitanas. 2002 (por mil habitantes).

Tabela 28: Taxa de internação da população feminina de 15 a 49 anos, por "Gravidez, parto e puerpério" (cap 15-CID10). Região Metropolitana, 2002. (por mil mulheres)

Tabela 29: Taxa de internaçăo (AlH 1 e 5) do grupo etário de 15 a 49 (exceto capitulo $15 \mathrm{CID} 10$ ). Regiöes Metropolitanas, 2002. (por mil habitantes) ........98

Tabela 30: AlHs de tipo $1^{*}$ de pacientes do grupo etário de 15 a 49 anos por Região Metropolitana, 2002.

Tabela 31: Taxa de internação por AlHs de tipo $1^{\star}$ de pacientes do grupo etário de 15 a 49 anos. Regiăo Metropolitana, 2002 (por 1000).

Tabela 32 Taxa de internação para o grupo etário de 15 a 49 anos, segundo diagnóstico (CID10). Regiões Metropolitanas, 2002. (Por 100 mil homens ou mulheres).

Tabela 33: Taxa de internação de homens e mulheres do grupo etário de 15 a 49 anos, por Doença pelo vírus da imunodeficiência humana (HIV), Doenças Infecciosas Intestinais e Hanseniase. Regiōes Metropolitanas, 2002. (por 100.000 habitantes, homens e mulheres)

Tabela 34: Taxa de internação do grupo etário de 15 a 49 anos. por Infecções de transmissão predominantemente sexual e tuberculose, segundo sexo. Regiões Metropolitanas, 2002. (por 100.000)

Tabela 35: Taxa de internação do grupo etário de 15 a 49 anos, por Transtornos Mentais e Comportamentais devido ao uso de substancias psicoativas, Esquizofrenias, Transtornos Esquizotípicos e Delirantes, e Orgânicos inclusive sintomáticos, segundo sexo. Regiőes Metropolitanas, 2002. (por 100.000). 119

Tabela 36: Taxa de Internação por Causas Externas $(X X)^{*}$ para o grupo etário de 15 a 49 anos

Tabela 37: Diagnóstico de internação segundo Região Metropolitana. 2002 ..... 134

Tabela 38: Taxa de mortalidade por sexo. Regiōes Metropolitanas, 2002. 139

\section{Gráficos}

Gráfico1: Proporção da população de 15 a 49 anos, segundo Regiões Metropolitanas. 2002.

Gráfico 2: da proporção por sexo na população de 15 a 49 anos. Regiões

Metropolitanas, 2002.

Gráfico3: Razão de masculinidade por grupo etário. Regiōes Metropolitanas, 2002.

Gráfico 4: Proporção de internações do grupo de 15 a 49 anos do total de internações. Regiões metropolitanas, 2002.

Gráfico 5: Taxa de internação do grupo etário de 15 a 49 anos, segundo diagnóstico (CID10). RM do N/NE de Santa Catarina (100 mil habitantes) ..................... 100

Gráfico 6: Taxa de internação do grupo etário de 15 a 49 anos, segundo diagnóstico (CID10). RM de Campinas, 2002. (100 mil habitantes) 
Gráfico7: Taxa de internação do grupo etário de 15 a 49 anos, segundo diagnóstico (CID 10). RM de Porto Alegre, 2002 (100 mil habitantes)

Gráfico 8: Taxa de internação do grupo etário de 15 a 49 anos, segundo diagnóstico (CID10). RM de São Luis, 2002 (100 mil habitantes) 102

Gráfico 9: Taxa de internação do grupo etário de 15 a 49 anos), segundo diagnóstico. RM de Maceió, 2002 (100 mil habitantes). 103

Gráfico 10: Taxa de internação do grupo etário de 15 a 49 anos, segundo diagnóstico. RM do Vale do Aço- Colar, 2002. (100 mil habitantes) .............. 103

Gráfico 11: Taxas de internação do grupo etário de 15 a 49 anos, segundo diagnóstico (por 100 mil homens). Regiőes Metropolitanas, 2002.

Gráfico 12: Taxa de internação para o grupo etário de 15 a 49 anos), segundo diagnóstico (por 100 mil mulheres). Regiōes Metropolitanas, 2002.

Gráfico 13: Taxas de internação para o grupo etário de 15 a 49 anos, por Algumas Doenças Infecciosas e Parasitárias. Regiōes Metropolitanas, 2002 (100.000 habitantes)

Gráfico 14: Taxas de internação para o grupo etário de 15 a 49 anos por Neoplasias (I). Regiōes Metropolitanas, 2002 (100000 habitantes)

Gráfico 15: Taxa de internação de mulheres do grupo etário de 15 a 49 anos, por Neoplasias Malignas dor Órgão genitais Femininos e Mama. Regiões Metropolitanas, 2002.

Gráfico 16: Taxas de internação para o grupo etário de 15 a 49 anos, por Transtornos Mentais e Comportamentais (V). Regiöes Metropolitanas, 2002 (100000 habitantes)

Gráfico 17: Taxa de internação por Doenças do Aparelho Circulatório, para o grupo etário de 15 a 49 anos. Regiōes Metropolitanas, 2002 (por 100.000 habitantes)

Gráfico 18: Taxa de internação do grupo etário de 15 a 49 anos, por Doenças do Aparelho Respiratório. Regiōes Metropolitanas, 2002

Gráfico 19: Taxa de internação do grupo etário de 15 a 49 anos, por Doenças do Sistema Digestivo. Regiōes Metropolitanas, 2002. (por 100.000) ................. 123

Gráfico 20: Taxa de internação do grupo etário de 15 a 49 anos, por Doenças do Sistema Geniturinário. Regiōes Metropolitanas, 2002.

Gráfico 21: Taxas de internação para o grupo etário de 15 a 49 anos, por lesões e envenenamentos e algumas outras conseqüências de causas externas.

Regiōes Metropolitanas, 2002 (100000 habitantes) 


\section{İndice}

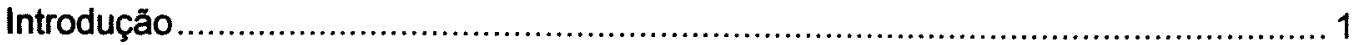

Capitulo I: Informação e Reflexividade ............................................................... 5

Informaçăo e Sociedade Contemporânea ......................................................... 5

Informação e política pública ............................................................................ 13

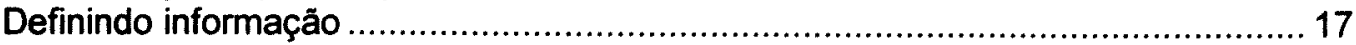

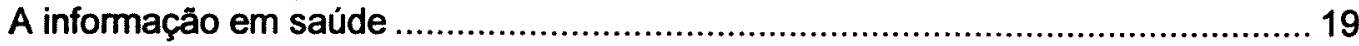

Os principais sistemas de informação em Saúde .............................................. 24

O Sistema de Informação Hospitalar- SIH/SUS ............................................... 30

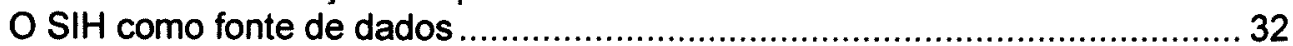

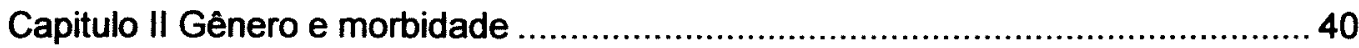

Entendendo o conceito de gênero como categoria de análise ............................. 40

Gênero e Saúde: do controle da natalidade aos direitos sexuais e reprodutivos 52

Morbi-mortalidade e gênero...................................................................... 55

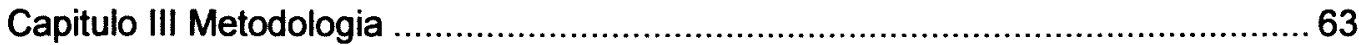

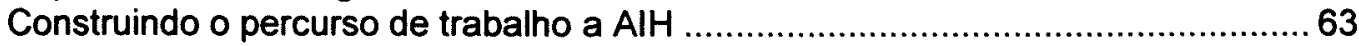

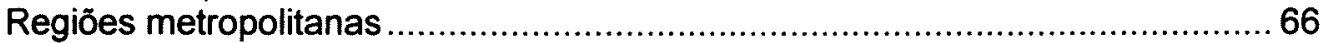

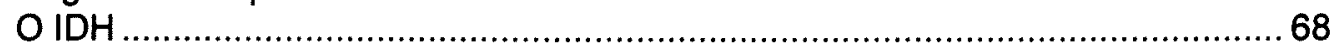

Capitulo IV Perfil das Regiões Metropolitanas ............................................... 70

Perfil Sócio-demográfico das Regiōes Metropolitanas ....................................... 70

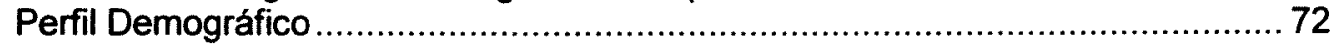

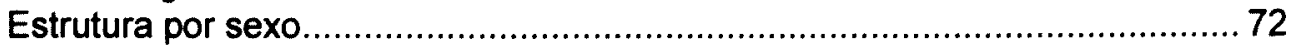

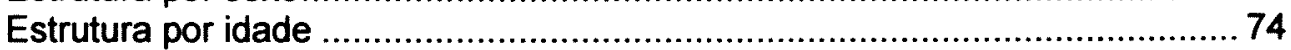

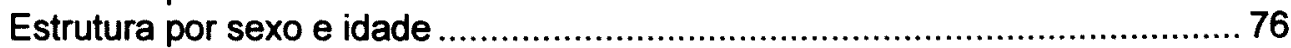

Fecundidade e crescimento populacional ................................................. 80

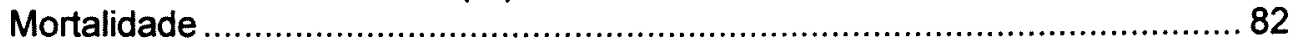

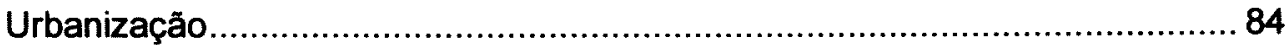

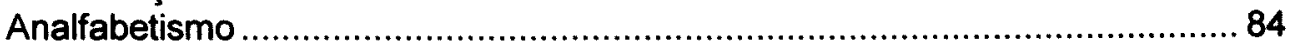

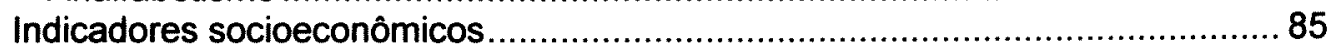

Oferta de Serviços e equipamentos de saúde ................................................... 87

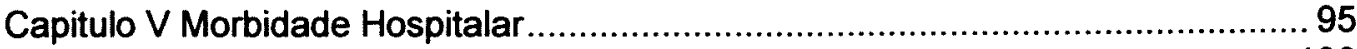

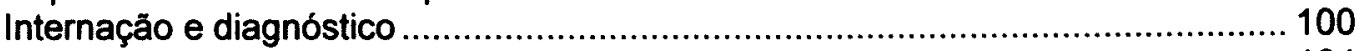

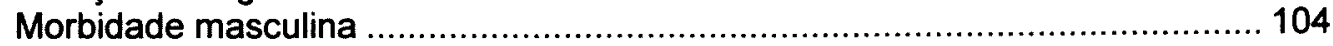

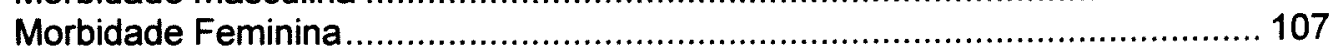

Comparando o perfil de morbidade masculina e feminina nas Regiões

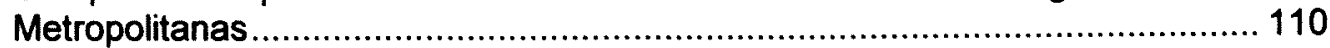

I Algumas doenças infecciosas e parasitárias ................................................ 113

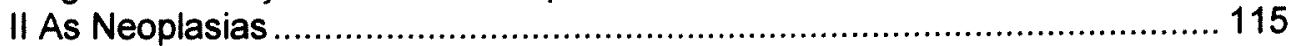

$\checkmark$ Transtornos mentais e comportamentais ................................................... 117

IX Doenças do Aparelho Circulatório ............................................................ 119

X Doenças do Aparelho Respiratório ......................................................... 121

XI Doenças do Aparelho Digestivo .......................................................... 123

XIV Doenças do Aparelho Geniturinário..................................................... 124

$\mathrm{XIX}$ Lesőes, envenenamento e algumas outras conseqüências de causas

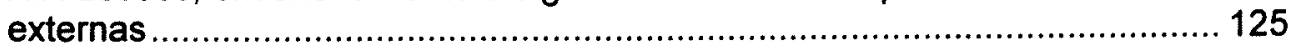




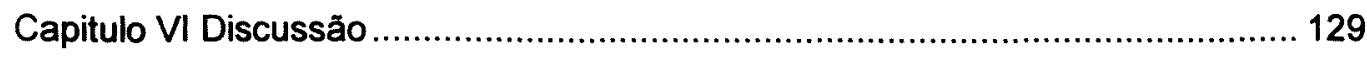

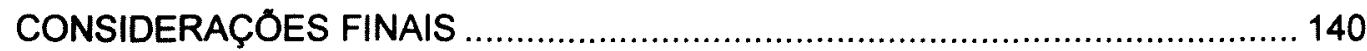

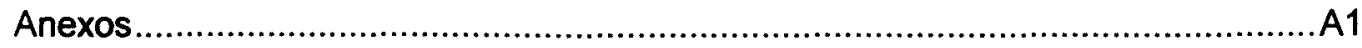

Anexo 1 Descrição dos Registros da AlH...........................................................

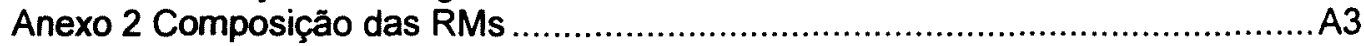

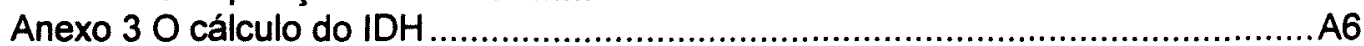

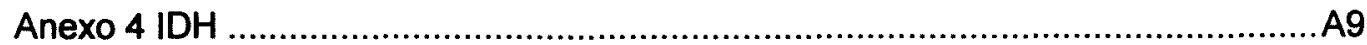

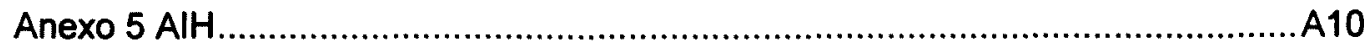

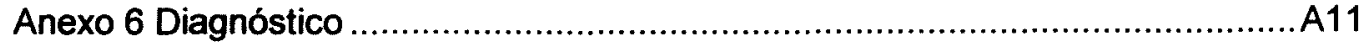

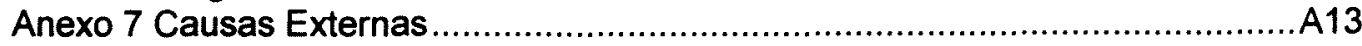




\section{Introdução}

"Olhar" a informação em saúde no País sob uma perspectiva de gênero, não é tarefa fácil, principalmente pelas limitações dos bancos de dados que, na sua grande maioria, foram idealizados com enfoques administrativos ou epidemiológicos. Mas, este motivo não foi suficiente para que desistíssemos da empreitada pois, como disse Louro (1996), a opção pelo emprego desse conceito significa "uma decisão de ordem epistemológica e (...) teórica" que , também para nós, vai além da academia, por entender a grande contribuição para melhor se compreender mais uma diferença que atravessa as relações sociais no mundo contemporâneo.

O tema desse trabalho é a morbidade hospitalar com um enfoque de gênero. Para isso, utilizamos o principal sistema existente no País: o Sistema de Informação Hospitalar-SIH. Sobre ele nos debruçamos por um longo período, buscando entender como o adoecer, enquanto fenômeno coletivo, se apresenta para homens e mulheres na rede pública hospitalar.

Para alcançarmos nosso objetivo, no capitulo I, iniciamos discutindo qual a importância da informação na sociedade em que vivemos, tendo em vista que a produção de bens materiais deixou de ser a essência da sociedade capitalista, e a informação ganhou papel de destaque, da sua produção à sua utilização.

A informaçăo traz consigo um caráter de vigilância, pois é utilizada pelo Estado como elemento de controle sobre a população, porém ela também é importante para nortear as decisões, tanto individuais quanto coletivas e ao ser apropriada por pessoas, grupos, movimentos sociais, passa a ter um caráter reflexivo e, portanto, representa um instrumento importante para as demandas e mudança social.

No plano individual ela passa a subsidiar as decisōes cotidianas, em um processo que Giddens (1996) denominou de reflexividade e, no plano coletivo a informação pode servir como elemento de luta de grupos organizados na sociedade para reivindicações frente ao Estado. 
A informação deveria subsidiar as politicas públicas voltadas para problemas e necessidades de grupos especificos na sociedade. Portanto, dentro desta lógica, as informações em saúde devem proporcionar conhecimento suficiente para o planejamento de políticas que atendam às demandas reais, uma vez que, entendemos como informação em saúde toda aquela que se relaciona ao processo saúde/doença. Assim, neste conceito se enquadra tanto a produzida como resultado direto desse processo, quanto as que se relacionam direta ou indiretamente a ele, como as condições socioeconômicas de uma população.

O Sistema Único de Saúde-SUS foi implantado após a Constituição de 1988. Porém, somente em 1995 uma Portaria ministerial cria um Grupo de Trabalho que deveria discutir a organização de um Sistema Nacional de Informação e Informática. Esse Grupo identificou problemas e definiu diretrizes, muitas das quais ainda, permanecem como problemas até hoje, apesar de todo o avanço tecnológico. Existe uma gama imensa de sistemas que são desenvolvidos no âmbito do Ministério da Saúde e poucos se intercomunicam entre eles. O SIH/SUS, que compõe o Sistema de Informação em Saúde-SIS que, pode ser considerado um dos mais antigos, pois se originou do Sistema de Assistência Médico Hospitalar-SAMHPS, implantado no inicio da década de 80 . Não é universal, porém se estima que cobre de 70 a $80 \%$ da atenção hospitalar no país.

Apesar de algumas críticas quanto às suas limitações, pois se trata de um banco de dados desenvolvido com uma lógica administrativa para fins de controle do financiamento do sistema de saúde hospitalar, todos admitem que se trata de uma importante fonte de dados relativos à morbidade.

Para podermos "olhar" para os dados desse Sistema, com um enfoque de gênero, no capítulo II, procuramos discutir sobre o significado desse conceito. Constatamos que se trata de um termo dinâmico, no sentido de que não existe uma definição única que tenha sido encontrada há tempos e jamais contestada. Pelo contrário, em nossa busca observamos que, a partir do movimento feminista na década de 60 , que trouxe à tona a 
discussão do caráter social das diferenças dos sexos, várias correntes teóricas contribuiram para entendimento do gênero como categoria de análise.

Em linhas gerais, a idéia presente é a de que, enquanto as diferenças biológicas se relacionam ao sexo, a categoria gênero pode ser entendida como uma construção social. Portanto, devemos compreendê-la dentro de um contexto sócio-cultural, sem perder a perspectiva histórica. Acrescentase a isso, por um lado, a multiplicidade de identidades de gênero; e, por outro, a transversalidade desse conceito, pois se agregam a ele as diferenças étnicas e socioeconômicas. Todos esses elementos vão contribuir para um perfil diferenciado da morbidade de homens e mulheres.

No terceiro capitulo, apresentamos o percurso percorrido para a realização do trabalho, as opções metodológicas e as variáveis utilizadas. Usando como recorte o Indice de Desenvolvimento Humano, selecionamos regiōes com melhores e piores índices, já que o banco de dados utilizado não possui uma variável socioeconômica. Esse recorte, feito a partir do Indice de Desenvolvimento Humano, buscou identificar semelhanças e diferenças no perfil da morbidade hospitalar entre homens e mulheres das distintas regiōes. Trabalhamos, então, com indices que buscassem cruzar a perspectiva sócio-econômica e as diferenças entre os sexos. As regiões escolhidas foram a RM do Norte/Nordeste de Santa Catarina-Núcleo, RM de Campinas, RM de Porto Alegre, RM de São Luis, RM de Maceió e Colar Metropolitano da RM do Vale do Aço.

Nosso pressuposto básico é o de que a partir da variável sexo, tomada como um indicador relativo, poderíamos realizar uma dada aproximação às possíveis questões de gênero. Da mesma forma, o IDH, apresenta-se como um indicador das condições socioeconômicas das regiões metropolitanas.

No capitulo IV e $V$, apresentamos os resultados, primeiro traçando um perfil sócio-demográfico e da disponibilidade de serviços para as RMs 
selecionadas, depois comparando as taxas de internação de homens e mulheres nas diferentes Regiões Metropolitanas.

No capítulo VI, discutimos sobre as dificuldades e limitações encontradas, bem como, as perspectivas dos resultados obtidos. Trabalhando com índices e com uma realidade social complexa, a ser expressa por esses indices, obtivemos resultados que apontaram para diferenças entre sexos que se aprofundaram ou que se tornaram mais evidentes a partir das diferenças sócio-econômicas; e ainda pudemos, como produto, verificar o caráter nivelador de uma política pública universalista como sistema único de saúde que atua como equalizador das desigualdades sociais e regionais. 


\section{Capitulo I: Informação e Reflexividade}

\section{Informação e Sociedade Contemporânea}

Existe, atualmente, uma diversidade de teorias que evidenciam ou colocam como tema central o papel da informação na sociedade. Apesar de não ser 0 objetivo deste trabalho tomar partido nessa discussão, na sociedade globalizada contemporânea, dominada pelo capital financeiro, a informação ocupa uma dimensão estratégica. Em relação às políticas sociais, ou às políticas voltadas para a melhoria da condição de vida das pessoas, a informação parece assumir um papel de gerenciamento dos bens que o Estado coloca em ação, sempre dependente da economia e do setor privado.

O que diferencia, em termos históricos, a sociedade industrial da sociedade da informação? Na primeira, o que movia o mundo capitalista era a produção de bens materiais, que foi substituida progressivamente pela produção de informação. Segundo Mostafa (1994), a sociedade permanece produtora de mercadoria, portanto de valor. Porém, se a Revolução Industrial significou uma "substituição da força física pela máquina", a revolução atual é a "Revolução da cabeça".

Giddens (1991) apresenta uma discussão interessante sobre o papel da informação na sociedade contemporânea. Considera que o momento de transição, que leva para além da modernidade, vem recebendo de diversas correntes, distintas denominações, que sugerem um novo tipo de "sistema social", ou o fim de uma era, tais como "sociedade da informação", "sociedade de consumo", "pós-modernidade", "pós-modernismo" ou "sociedade pós-industrial". Afirma esse autor que, dentre os debates atuais sobre este tema, sobressai a questão de que "estamos nos deslocando de um sistema baseado na manufatura de bens materiais para outro relacionado mais centralmente com a informação"(Giddens 1991, p.11). 
Segundo ele, a modernização não teria se esgotado, mas os seus principais aspectos estariam sendo radicalizados no fim do século $X X$. Acredita que vivemos um período em que as conseqüências da modernidade foram levadas ao extremo e, portanto, é necessário obter-se "uma nova caracterização tanto da natureza da modernidade, quanto da ordem pós-moderna que deve emergir do outro lado da era atual" (Giddens 1991, p.13).

Ao caracterizar a modernidade Giddens (1991), coloca em evidência seus limites contrapondo sua promessa de segurança, à exposição cada vez maior e mais complexa ao perigo e a idéia de maior confiança versus risco, visando demonstrar que a modernidade apresenta, no final do século $X X$, dois lados contraditórios: por um lado, o desenvolvimento criou meios para garantir um viver mais seguro; por outro, apresenta um lado obscuro. Ameaça nuclear, questões ecológicas e a arbitrariedade do totalitarismo, representam alguns dos riscos do viver no mundo atual.

A informação, na análise de Giddens (1991), aparece como elemento da "Vigilância" que, juntamente com o "Capitalismo", o "Poder Militar" e o "industrialismo" constituem-se em "dimensões básicas da modernidade" (Giddens 1991, p.63). O capitalismo seria um "sistema de produção de mercadorias, centrado na relação entre propriedade privada do capital e o trabalho assalariado sem posse de propriedade"; o industrialismo teria como principal característica o "uso de fontes inanimadas de energia material na produção de bens, combinado ao papel central da maquinaria no processo de produção"; a quarta dimensão é explicada pelo "controle dos meios de violência", conseguido através do poder militar, caráter especifico dos "Estados modernos" (Giddens 1991, p.63).

Na sociedade capitalista, o Estado atingiu um nível de "coordenação administrativa" que nunca os Estados pré-modernos foram capazes de atingir. Essa, por sua vez, originou uma concentração administrativa que depende do aparato da vigilância que, segundo Giddens (1991, p.63), se "refere à supervisão das atividades da população súdita na esfera política- 
embora sua importância como uma base do poder administrativo não se confine a esta esfera. A supervisão pode ser direta (como em muitas das instâncias discutidas por Foucault, tais como prisões, escolas e locais de trabalho abertos) mas, mais caracteristicamente, ela é indireta e baseada no controle da informação".

Nessa sociedade, a informação, além de representar um elemento primordial no controle feito pelo Estado, também tem papel de destaque na vida das pessoas. Para entender a importância da informação no âmbito individual, passamos a resgatar o conceito de reflexividade (Giddens 1996).

Nas sociedades contemporâneas, a ciência e o conhecimento científico não são privilégios apenas dos "peritos", na medida em que o indivíduo no mundo atual recebe uma gama de informações científicas, ou não, que passa a fazer parte de seu cotidiano e a influenciar em suas decisões. A este processo, Giddens (1996) denomina "reflexividade". Passamos a viver em um mundo de reflexividade social, colocada para o autor como pré-condição e resultado de uma sociedade pós-tradicional. As decisões passam a ser "tomadas com base em uma reflexão mais ou menos contínua sobre as condições de cada um" (p.101).

Para um melhor entendimento desta discussão, retomamos alguns temas abordados pelo autor.

Segundo Giddens (1996), nas sociedades "destradicionalizadas", as condutas dos indivíduos já não são baseadas em tradições, pois com a expansão da reflexividade social, passamos a filtrar todos os tipos de informação relevantes para as situações em nossas vidas.

Um mundo de reflexividade intensificada é um mundo de pessoas inteligentes. Os indivíduos têm, mais ou menos, que se engajar com o mundo em termos mais amplos se quiserem sobreviver nele. A informação produzida por especialistas (incluindo o conhecimento científico) não pode mais ser totalmente confinada a grupos específicos, mas passa a ser interpretada rotineiramente e a ser influenciada 
por individuos leigos no decorrer de suas ações cotidianas.

Em uma sociedade de alta reflexividade, a apropriação regular da pericia - em todas as suas muitas formas - tende a substituir a orientação da tradição (Giddens 1996, p.15).

Com o desenvolvimento da reflexividade social, as mudanças não săo apenas individuais, mas se ampliam. A própria emergência do "pósfordismo" e o "crescimento da produção flexivel" foram reflexo de uma tomada de decisões de baixo para cima, fruto de um "universo de alta reflexividade" que nos leva a uma maior autonomia.

A reflexividade social, para o indivíduo, não deve ser confundida com o individualismo pregado pelo neoliberalismo, estando muito mais próxima da idéia de que a autonomia implica reciprocidade e interdependência nas diversas esferas da vida social. Este repensar do indivíduo segundo Giddens (1996), forneceria as bases para uma restauração das "solidariedades danificadas".

A ampliação da solidariedade, em uma sociedade "destradicionalizada", está relacionada com a confiança ativa, significando uma

renovação de responsabilidade pessoal e social em relação aos outros. A confiança ativa é a confiança que tem de ser conquistada, em vez de vir da efetivação de posições sociais ou de papéis de gênero, (...) pressupõe autonomia em vez de posicionar-se contra ela. Além disso, ela é uma fonte poderosa de solidariedade social, uma vez que a transigência é livremente oferecida em vez de ser imposta pelas coerçőes tradicionais (Giddens 1996, p.22).

A confiança ativa, em união com a reflexividade social, conceberá uma "política gerativa", a qual visa propiciar aos indivíduos e grupos uma atitude de enfrentamento dos problemas, em vez destes esperarem que as coisas aconteçam. 
A política gerativa é uma defesa da política do domínio público, mas ela não se situa na velha oposição entre Estado e Mercado. Ela opera fornecendo condiçōes materiais e estruturas organizacionais para as decisões de políticas de vida por indivíduos e grupos na ordem social mais ampla. Uma política dessas depende da construção de confiança ativa, nas instituições do governo ou nas agências que a elas estão ligadas.

O autor considera que a "política gerativa é o principal meio de se abordar com eficiência os problemas da pobreza e de exclusão social nos dias de hoje" (Giddens 1996, p.24).

Esse engajamento politico, não ocorre de maneira uniforme. Vivemos, nas sociedades contemporâneas, sob uma "modernização reflexiva", significando que uma boa parte da população vive no mesmo "espaço descritivo", porém as pessoas podem ou năo se engajar reflexivamente às questões políticas.

Ao contrário de pensar que os programas políticos atingiram um alto grau de complexidade, restringindo-se a alguns especialistas, é possível vislumbrar um momento privilegiado, comparado com momentos anteriores, no qual as informações "sobre problemas e eventos atuais" são debatidos publicamente e com maior freqüência. Diante dessas novas circunstâncias um perito de uma área de conhecimento pode ser considerado um leigo em outras; por outro lado, uma pessoa leiga pode apropriar-se de conhecimentos especificos.

Nessa linha de reflexão afirma Giddens (1996) que nenhum "perito" possui verdades e conhecimentos absolutos, podendo ser contestado por um outro perito de sua própria área, pois mesmo, em um contexto de reflexividade social, existe a possibilidade de um conhecimento tornar-se obsoleto, e, assim, a perícia não se constitui em exclusividade.

Quaisquer afirmações de um especialista em relação a conhecimento relevante para as tarefas práticas da vida social 
tenderão a ser deflacionadas ao se tornarem o meio circulante comum, embora freqüentemente de maneira imperfeita. $O$ prestígio da própria ciência, tão fundamental para as fases anteriores do desenvolvimento das instituições modernas, torna-se subvertido por esse mesmo ceticismo que é o motor do empreendimento científico (Giddens 1996, p.112).

Aplicando este raciocínio a questōes ligadas à saúde, por exemplo, uma pessoa, quando está diante de um problema de saúde, poderia procurar, na maioria das vezes, uma fonte única para diagnóstico e resolução do problema, recursos da "esfera da ciência ortodoxa e da tecnologia médica". Mas acontece, às vezes, de procurar mais de um recurso e, ainda, pode encontrar uma enorme diversidade de práticas alternativas e, mesmo estas, também podem ser contestadas.

Com as noções de "modernização reflexiva", ou sociedade reflexiva, Giddens (1996) busca apontar o fato de que, no mundo contemporâneo, a informação "perita" ou "cientifica" circula e penetra pelos diversos canais de comunicação de massa e das relações interpessoais, propiciando a "reflexividade", a filtragem, ou a reelaboração desta informação.

Para Giddens, a "reflexividade" é indispensável para a democracia, pois considera que com a ordem social reflexiva e globalizadora, faz-se necessária uma radicalização da democratização, ou seja, é de crucial importância uma "democracia dialógica". Esta, segundo o autor, pressupōe apenas que o diálogo em um espaço público forneça um modo de viver com o outro em uma relação de tolerância mútua - "seja esse outro um indivíduo ou uma comunidade global de fiéis religiosos" (Giddens 1996, p.133). Implica em relações com o Estado de maior "transparência" no governo e, mesmo as relaçōes pessoais, devem se travar através do "intercâmbio de idéias, da discussão", em vez de se darem por formas "preestabelecidas de poder".

Entendemos, neste ponto, que ocorre um processo de democratização do plano individual, para o público. Segundo o autor, ocorrendo uma "democracia das emoções" haverá, conseqüentemente, um 
aumento da democracia pública e formal. "Os indivíduos que têm um bom entendimento de sua própria constituição emocional, e que são capazes de se comunicar de maneira eficiente com os outros em uma base pessoal, provavelmente estão bem preparados para as tarefas e responsabilidades mais amplas da cidadania" (Giddens 1996, p.25).

Uma outra forma de mobilizar a democracia dialógica é por meio dos grupos de auto-ajuda e movimentos sociais, que contribuem, ainda, para a reflexividade intensificada da atividade social local e global. Esta característica advém do fato de estes grupos propiciarem um diálogo de assuntos que interessam ao público. Para Giddens (1996), estes grupos podem contribuir para uma disseminação global das formas de democracia, pois muitos deles são globais, pelo menos em intenção e, ainda, por termos cada vez mais ampliada a idéia de um governo mundial.

Assim é que, para o referido autor, a democracia dialógica não se restringe ao plano político, transcendendo e interligando outras esferas de relações sociais. A primeira delas, está no plano da vida pessoal. O casamento, a sexualidade, a amizade, a relaçăo pais e filhos, foram alteradas pela destradicionalização e reflexividade, repercutindo no mundo todo; caminhamos segundo Giddens, para "relacionamentos puros", entendidos como "um tipo ideal no sentido sociológico".

Neste sentido podemos associar a discussão de gênero como mais um estatuto da destradicionalização, ao questionar as diferenças que se estabelecem a partir da relação entre os sexos, seja pela relação de poder, seja pelos papéis atribuídos, seja pela transformação mesma destas identidade tradicionais. Há, neste raciocínio, uma estreita relação entre relacionamento puro e democracia dialógica. Os indivíduos que se comunicam eficientemente uns com os outros, podem estender essa habilidade para contextos mais amplos, inclusive no exercício da cidadania.

Retomando a discussão de risco, citada anteriormente, para Giddens (1996) vivemos em um mundo de incerteza artificial, resultado do "desenvolvimento a longo prazo da ordem industrial". Apesar de todo "o 
avanço do conhecimento humano e a intervenção controlada na sociedade e na natureza", não foi conquistado um viver seguro e nem mesmo um rígido controle da natureza; ao contrário, segundo Giddens, estamos cercados de "imprevisibilidade".

O autor não considera que o risco sobre nossas vidas seja maior, trata-se de uma mudança, já que o "risco artificial é um resultado da intervençăo humana", ao contrario do "risco externo", que estava muito mais ligado à noção de acidente, ou azar. O conceito de risco traz "todo o peso da filosofia iluminista", e a incerteza artificial ou risco artificial contradizem a posição iluminista, que considerava "mais conhecimento" como equivalente a "mais poder".

A noção de risco estaria associada a uma maior responsabilidade do individuo, enquanto ser coletivo. Tal idéia relaciona-se ao que Giddens denominou de o "eu autolítico", um ser consciente de seus limites, mas que também se propõe a desafios. Definido como "aquele que apresenta uma confiança interna que vem do amor próprio e no qual um sentido de segurança ontológica, que se origina em confiança básica, permite a apreciação positiva da diferenciação social". Refere-se a uma "pessoa capaz de traduzir potenciais ameaças em desafios gratificantes, alguém que é capaz de transformar entropia em um fluxo coerente de experiências. O eu autolítico nāo procura neutralizar o risco ao supor que "uma outra pessoa vai cuidar do problema" (Giddens 1996, p.219).

Independentemente das diferentes denominaçōes encontradas para a sociedade contemporânea, a idéia básica a reter é a de que a informação é elemento central, ampliando-se da esfera individual para a coletiva. Em uma sociedade reflexiva, com incertezas artificiais, o acesso de indivíduos e grupos da sociedade à informaçăo em geral, e especificamente em saúde, torna-se elemento fundamental para a redução do risco, cabendo portanto, ao Estado cumprir o papel de viabilizar esse acesso e, assim, romper com o paternalismo que impera nas políticas públicas. 


\section{Informação e política pública}

Diante de sua importância na vida contemporânea, a informação pode ser entendida enquanto possível alvo de política pública. Portanto podemos pensar o Estado, por um lado, como provedor do acesso dos cidadãos à informação; por outro, como produtor e usuário das informações. Podemos ainda, dizer que a informação constitui-se em mecanismo de poder, visto que pode ser manipulada em benefício de certos grupos.

$\mathrm{Na}$ definição proposta por Demo, politica social consiste em uma resposta "planejada de enfrentamento das desigualdades". Trata-se de uma tentativa de conciliação entre "alguns privilegiados que controlam a ordem vigente, e a maioria marginalizada que a sustenta" (Demo 1994, p.7). Assim, entendemos a política pública como mais uma via de acesso à cidadania, a partir de uma política do Estado.

Em Rodrigues (1991) nos deparamos com uma distinção entre políticas públicas e políticas sociais, em que ele destaca 0 caráter eminentemente político do Estado, embora sofra solicitações que oscilam entre o social e o econômico. A questão social, produto da Revoluçăo Industrial, propicia subsídios para a compreensão da "natureza e dos fins" do Estado Moderno. Neste momento inicial, o povo não possuía lugar de destaque. Distintamente, na sociedade contemporânea o Estado, além de representar um "instrumento de poder(es)" traz consigo "um complexo sistema de prestação de serviços, que se desdobram em função das demandas sociais" (Rodrigues 1991, p.11). Neste novo contexto ganham destaque as questões demográficas, como a concentração da população nas cidades. Portanto, o espaço urbano torna-se lócus privilegiado no embate entre cidadãos e o poder.

A política pública apresentaria, portanto, uma característica típica de países socialistas, podendo ser utilizada em países capitalistas, isto é, "compõe as iniciativas que envolvem uma alta dose de racionalidade dos programas de atividades, sob a forma de planejamento", implicando em mudanças estruturais. Em contraposição, a política social "compõe as ações 
que constituem respostas concretas às funções sociais (do Estado) que se ampliaram consideravelmente" (Rodrigues 1991, p.14). Rodrigues apresenta, ainda, a diversidade de ações sociais do Estado Capitalista voltadas para as questões sociais, propiciando uma diversidade de Estados funcionando concomitantemente: Estado-previdência, Estado trabalhista sindical, Estado sanitário e Estado educação.

A distinção entre as "noçőes" de políticas públicas, planejamento estatal e políticas sociais, faz-se necessária, tendo em vista sua utilização indiscriminada e por não atingirem a "dimensão de conceito" (Augusto 1989, p.105).

O planejamento estatal, vinculava-se ao pensamento desenvolvimentista. Foi considerado nos anos 50 e meados dos 60 , a forma privilegiada de ações do Estado. Nesse período, era percebido como instrumento de "controle racional da História (...), capaz de conduzir ao desenvolvimento econômico e à autonomia nacional, deveria, para tanto, estar alicerçado na eficácia e na competência técnicas, o que possibilitaria a realização de mudanças planejadas. Sua utilização possibilitaria uma transformação da ordem social, dirigindo o país a mudanças estruturais" (Augusto 1989, p.106).

Diferentemente, a noção de políticas públicas, possui um caráter transformador bem menor. "Trata-se, antes, da imposição de uma racionalidade específica às varias ordens de ação do Estado, um rearranjo de coisas, setores e situações" (Augusto 1989, p.106).

Como conseqüência dessa discussão inicial, a autora nos remete para uma reflexão sobre o "âmbito do público e privado no Brasil”. Segundo ela, a intervenção estatal deveria ter como objeto o interesse geral, porém devido às características do Estado, espaço de domínio e conflito, o que se verifica são ações privilegiando a determinados sujeitos/grupos. Portanto, a contraposição entre o que é público e privado fica ocultada, na medida em que o Estado, enquanto mediador, pode privilegiar situaçōes particulares alegando-as como de interesse geral. No Estado brasileiro observamos a 
tendência em implementar políticas setoriais, onde o "único elemento aparente e explícito a unificá-las é o fato de serem públicas, isto é, ocorrem a partir do aparelho estatal" (Augusto 1989, p.108).

No que se refere a uma elucidação da noção de políticas sociais, Augusto apresenta que os diferentes estágios de constituição da sociedade capitalista levam a distintas formas de direitos: "direitos civis, direitos políticos, direitos sociais". Estes últimos dizem respeito ao bem-estar coletivo e à garantia de um nível mínimo de consumo, para todos os cidadãos. $E$ considera que a discussão sobre políticas sociais limitou-se à constatação empírica da atuação estatal, em detrimento do "significado político", embora seja possível tecer alguns comentários no sentido de uma análise das políticas sociais. Segundo ela, estas teriam como características "o caráter compensatório e redestributivo", funcionando como "importante instrumento de controle dos antagonismos sociais" (Augusto 1989, p.110).

Encontramos, em Offe (1984), uma explicaçăo das políticas sociais, utilizando como categoria básica a força de trabalho. Nesta abordagem, o Estado tem como papel fundamental regular a inserçăo e controlar o trabalho assalariado.

A politica social representa uma estratégia de integração de força de trabalho na relação de trabalho assalariado, i. é, uma relaçăo que somente poderia adquirir a difusăo e a normalidade que hoje existem graças à efetividade dessa estratégia. Neste sentido a politica social não é mera reação do Estado aos problemas da classe operária mas contribui de forma indispensável para a constituiçăo dessa classe. A função mais importante da política social consiste em regulamentar o processo de proletarização (Offe 1984, p.22).

Neste tipo de abordagem, o Estado não significa um corpo monolítico a serviço do capital, mas a expressão de uma relação de interesses e força de classe em conflito. 
A discussão anterior permite diferenciarmos política publica, política social e planejamento estatal, e esclarece também que o Estado não é um corpo monolitico, pois na verdade oculta o jogo de forças e interesses. Neste jogo a informação exerce um papel importante, pois a mesma proporciona poder a grupos na sociedade. Em um Estado democrático devem existir políticas públicas claras que garantam o acesso à informação, com equidade, para os diferentes grupos sociais.

O papel do Estado em relação à informação, não se restringe apenas à garantia do acesso, ele também produz e controla. Se por um lado, o Estado representa um dos principais produtores de informação sobre a vida dos cidadăos, por outro, também deve ser o maior usuário, utilizando as informaçóes coletadas como base para o planejamento de suas ações, Porém, nem sempre isso acontece, nem mesmo ele que produz é capaz de utilizá-la com esse fim. Quanto ao controle do acesso, o Estado deve ter uma política clara definindo quem deve ter acesso a quê, ou se todos devem ter acesso a tudo. 


\section{Definindo informação}

Com o avanço tecnológico aumentamos cada vez mais nossa capacidade de produção de dados, porém, isto năo garante o uso e a transformação deles em informação. Aqui buscamos esclarecer o significado do termo utilizado nesse trabalho.

A todo momento, recebemos uma gama de informações especializadas, ou não, que, de certa forma, passam a nortear nossas ações, ou seja, em função delas passamos a fazer opções em nossa vida. A informação tem um sentido político, não é apenas um banco de dados. Entendemos que o dado é um símbolo, portanto, um banco de dados é um conjunto de símbolos e a informação traz consigo o significado, ela garante que o dado se torne compreensível.

Para Moraes, informação é uma "descrição mais completa do real associada a um referencial explicativo sistemático. Pode-se dizer que é a representação de fatos da realidade com base em determinada visão do mundo, mediante regras de simbologia. É, portanto, a 'ponte' entre fatos da realidade, ou as idéias de algumas pessoas e as idéias ou conhecimentos de outras", enquanto que dado "é uma descrição limitada do real, desvinculada de um referencial explicativo e difícil de ser utilizada como informaçăo por ser ininteligivel" (Moraes 1994, p.19).

A necessidade de um emissor e receptor é uma outra característica da informação, ou seja, um dado somente se torna informação quando existe um emissor e um receptor, capaz de decodificar os símbolos. Para Barreto (1994, p.3), o fenômeno da informação implica processo de comunicação entre emissor e receptor.

Nessa ótica, a informação não se constitui em um fim em si mesma; esta é apresentada pelo autor enquanto "estrutura significante", capaz de produzir o conhecimento, quando assimilada corretamente pelo indivíduo, modificando seu "estoque mental de informaçōes trazendo benefício para si e para a sociedade", implicando uma alteração do individuo e da sociedade. 
Além da decodificação dos símbolos por um receptor, o processo de modificação do dado, em informação, também implica na capacidade desse receptor ter sua açăo alterada pela informação recebida. Portanto, ela tem um potencial transformador (Senra 1994).

Ainda se faz necessário diferenciar a informação do processo de comunicaçăo. Rodrigues, ao discutir a "experiência cultural na era da informaçãon", ressalta a distinção entre o domínio da comunicação e o da informação. Segundo o autor, a delimitação destas duas "esferas de experiência da vida coletiva" tornou-se mais clara com o avanço da tecnologia, que propiciou um avanço dos processos informativos, sem que ocorresse 0 mesmo com a experiência comunicacional. Podemos nos comunicar sem transmitir nenhuma informação, assim como podemos transmitir informação sem criarmos quaisquer laços sociais (Rodrigues 1994, p.75).

Na perspectiva desse autor, na comunicação "intervêm processos de interlocução e de interação que criam, alimentam e restabelecem os laços sociais e a sociabilidade entre individuos e grupos", que partilham a mesma experiência. Tal fato não ocorre necessariamente na transmissão de informaçăo, "apesar de a esfera informativa se alargar cada vez mais até aos confins do mundo, a sua percepção vai se tornando cada vez mais individualizada, intimista, despojada de quaisquer funçŏes comunicacionais" (Rodrigues 1994, p.75).

A informaçăo representa algo que vai além do dado, implica na existência de um receptor $e$, considerando que a mesma vincula-se a um "referencial explicativo sistemático", neste trabalho nossa interpretação dos dados será baseada nos aspectos socioeconômicos do processo saúde/doença e no conceito de gênero. 


\section{A informação em saúde}

Não podemos dizer que inexistam dados ou informações em saúde no Brasil. Periodicamente uma imensa gama de dados são coletados para alimentar os diferentes bancos que compõem o Sistema de Informação em Saúde Nacional: dados epidemiológicos, estatísticas vitais, assistência ambulatorial e hospitalar. Todos esses dados coletados deveriam produzir informação necessária para o planejamento e tomada de decisōes na área de saúde, mas nem sempre isso acontece.

De acordo com definição do Ministério da Saúde (MS), informação em saúde é

aquela produzida pelo próprio setor como as de interesse para a saúde, nas áreas de demografia, morbidade, produção de serviços, vigilância sanitária, recursos setoriais, ecologia humana e saúde ambiental, ciência e tecnologia, legislação, bibliografia, administraçăo de sistema e serviços, bem como aquelas relativas às áreas econômica e social (MS 1995, p.91).

Para Moraes, uma das características da informação em saúde no Brasil é a fragmentação, segundo ela, reflexo da "evolução das práticas de saúde em nosso país orientada pela racionalidade fragmentadora da realidade que caracteriza o modelo como o Estado Brasileiro responde, através de seu aparato institucional, as demandas e crises colocadas pela sociedade" (1994, p.13). Esta prática recorrente do Estado Brasileiro, dificulta os espaços para a reivindicação. $A$ autora destaca que a produçăo de informação no Brasil, sempre atendeu aos interesses do Estado, geralmente centralizador e, em outras, descentralizador, porém com a função de manter o controle da população.

A preocupaçăo com a informaçăo no País não é recente. Em 1585 o Padre José de Anchieta realizou um levantamento da população colonial e registrou um total de 57.000 habitantes. Nesse momento, o que motivou a 
coleta do dado foi uma preocupação com as "almas", enquanto mais tarde seriam os interesses militares e resultados eleitorais que norteariam as pesquisas (Moraes 1994). No período do Brasil independente, começam a aparecer trabalhos de estudo e divulgação estatísticas, com o interesse voltado à população, aos subsídios, as operações de finanças, ao Exército e a Marinha (Moraes 1994).

Somente no século XX, em 1931, começam a ser trabalhadas em nivel nacional as "informações consideradas como relativas a saúde". O órgão responsável era a então "Diretoria Geral de Informaçōes Estatísticas e Divulgaçăo do Ministério da Educação e Saúde". Posteriormente, foi transformada no Serviço de Estatística da Educação e Saúde, que veio a fazer parte de um conjunto de órgãos, que constituiria o Instituto Nacional de Estatísticas (Moraes 1994).

Em 1937 é criado o Conselho Brasileiro de Geografia que, no ano seguinte, é unificado com o Instituto Nacional de Estatística, conformando o Instituto Brasileiro de Geografia e Estatística - IBGE. Tratava-se de uma entidade de natureza federativa, da qual faziam parte órgãos federais, estaduais e municipais, partindo de um "...esquema de hierarquia centralizadora" (Baldijão 1992, p.21).

No início da década de 60 podia-se verificar uma preocupação referente à importância de estatísticas como instrumento necessário para o planejamento e para tomada de decisões. E, com a Reforma Administrativa de $1 / 1 / 67$, tendo como finalidade a modernização da máquina estatal atendendo a critérios de centralizaçăo e racionalizaçăo, a informação passa a significar um aspecto "chave", enquanto subsídio para o planejamento e tomada de decisões. Tal fato pode ser verificado em 15/2/67, quando o IBGE se transforma em Fundaçăo subordinada ao Ministério do Planejamento e passa a ter como "...encargo prioritário a execuçăo do Plano Nacional de Estatisticas Básicas, compreendendo informaçōes essenciais ao planejamento econômico social do país e à segurança nacional" (Baldijão 1992, p.22). 
Na década de 70, as informações em saúde passam a ser produzidas pelo IBGE, ficando como órgão responsável pelas Estatísticas Vitais. No ano de 1975, começam a ser divulgados anualmente os dados referentes aos serviços de saúde no país (Baldijão 1992). Além das informações em saúde produzidas pelo IBGE, tínhamos ainda em nível nacional o INAMPS e o Ministério da Saúde.

O Sistema de Informaçōes do INAMPS estruturou-se "por uma lógica contábil, quantitativa e centralizadora, elegendo como evento básico de interesse (...), o procedimento médico. Organiza a partir dai suas informações, de forma centralizada, por tipos de prestador (...) e por dados financeiros (conforme as tabelas de pagamento e indices que variam em função do tipo de prestador, ou seja, das condições de pressão deste ou daquele setor envolvido no complexo médico-previdenciário)" (Moraes 1994, p.60).

Quanto ao Ministério da Saúde, a organização de seus Sistemas de Informação era movida por uma "...racionalidade campanhista, criadora de Programas verticalizados, voltados para determinados agravos ou grupos de risco. Assim, cada área, isoladamente, define 'seu próprio' sistema de informações centralizado que, deste modo, acabou por imprimir sua 'marca' no SIS das Secretarias Estaduais e Municipais de Saúde" (Moraes 1994, p.60).

No ano de 1988 foi promulgada a nova Constituição e com ela o Sistema Único de Saúde - SUS, que implicava em um novo modelo de atenção à saúde. Entre suas principais diretrizes estava a universalização e a descentralização do sistema de saúde no país. Esse novo modelo transferia em parte, para $\circ$ âmbito do município, o debate da relação entre cidadãos, Estado, Politicas Públicas e Sociais. Questões relacionadas à Educaçăo, ao Conselho da Criança e Adolescente, Meio Ambiente e Promoção Social passam a fazer parte da realidade municipal, tendo a saúde papel de destaque neste processo. 
O município tornou-se espaço privilegiado para a discussão da democratização das políticas públicas de saúde $e$, conseqüentemente, dos serviços de saúde. Neste processo, a organização e participação da população, juntamente com a descentralização de poder, tornaram-se fundamentais.

O SUS representou uma proposta inovadora de atenção a saúde, mas também trouxe o desafio do uso da informação como elemento no planejamento das ações de saúde, tanto em nivel local quanto nacional. Visando a organização de um Sistema de Informação em Saúde para o SUS, no ano de 1995 o Ministério da Saúde, em Portaria Ministerial de $n^{\circ}$ 1311, criou um Grupo de Trabalho que tinha como propósito discutir a organização de um Sistema Nacional de Informação e Informática em saúde para subsidiar o novo modelo assistencial adotado (Ministério da Saúde 1995). Este grupo optou por usar como referência documento existente do GERAS ${ }^{1}$, que já possuía os elementos básicos para discutir o assunto. Após rediscuti-lo e atualizarem os termos, rebatizara-no com o título de "Documento Básico do Sistema de Informação de Saúde".

O documento elaborado reconhecia a necessidade de um Sistema de Informação que subsidiasse a efetivação do Sistema Único de Saúde, refletindo a descentralização e garantindo o acesso de todos à informação, diretrizes desse novo modelo de assistência. Para tal, considerava-se que não bastaria um SIS capaz de quantificar um evento, mas também de contextualizá-lo, gerando dessa forma conhecimento que desse suporte a tomada de decisões políticas e técnicas.

Naquele momento, o balanço da situaçăo revelava que, em nivel federal, existiam sistemas compartimentalizados, com articulação deficiente. Em nível estadual e municipal, a situação era ainda mais precária, pois, quando existiam, os órgãos responsáveis pela informação possuiam diferentes graus de desenvolvimento e necessidades, sendo que na maioria deles a escassez de recurso humano capacitado era o principal problema.

\footnotetext{
Grupo Executivo da Reforma Administrativa da Saúde.
} 
Partindo dessa problemática buscou-se definir os princípios e diretrizes do SIS.

Os principios propostos foram:
a) "adequação aos principios e diretrizes do SUS (...);
b) clareza dos mecanismos de produção das informações (...);
c) privilégio de competência para os niveis periféricos (...);
d) responsabilidade dos órgãos produtores e divulgadores, quanto à qualidade (...);

e) respeito ao direito do cidadão à privacidade (...);

f) direito da população às informações (...);

g) competência e dever de dar a conhecer à população do que é feito com os recursos públicos". (MS 1995, p.89)

De acordo com o documento, o SIS deveria obedecer às seguintes diretrizes:

a) "Avaliar e apoiar o planejamento, a tomada de decisōes e as açōes em todos os niveis (político-estratégico, gerencial e operacional) do arcabouço organizacional do SUS;

b) Apoiar o desenvolvimento científico e tecnológico do setor saúde;

c) Subsidiar a avaliaçăo das relaçōes e eficiência e efetividade das políticas, das estratégias e das ações de saúde;

d) Apoiar o desenvolvimento e capacitação de recursos humanos no setor saúde;

e) Subsidiar o processo de comunicação dos órgãos do setor saúde com a populaçăo, ai entendida tanto em seus estratos organizados (conselhos e entidades), quanto com a população em geral" (MS 1995, p.89). 
Interessante ressaltar que, naquele momento, foi apontado como premissa básica que um dado só deveria ser coletado, desde que sua importância e utilidade fossem justificadas.

Muito já se avançou sobre o assunto, no âmbito da Saúde Pública, no Pais, porém, vários problemas detectados nesse período permanecem até hoje sem uma solução.

Desde a implantação do SUS, a informação em saúde apresenta grandes desafios aos gestores de saúde:

$\left.1^{\circ}\right)$ Romper com o centralismo, a fragmentação e a dificuldade de acesso.

$\left.2^{\circ}\right) \bigcirc$ repasse de verbas federais, que se dá mediante informações referentes à produção de serviços. Portanto, corre-se o risco das informações epidemiológicas e administrativas serem subestimadas em favor das informações que se revertem em mais verbas e pagamentos.

$\left.3^{\circ}\right)$ Criar mecanismos de disseminação democrática da informação à população e possibilitar que ocorra uma efetiva organização e participação da população nas políticas de saúde.

\section{Os principais sistemas de informação em Saúde}

Em nivel nacional, os principais bancos de dados de saúde săo: o Sistema de Informações Sobre Mortalidade (SIM), o Sistema Nacional de Nascidos Vivos (SINASC), o Sistema de Informação sobre Agravos de Notificação (SINAN), o Sistema de Informações Ambulatoriais (SIA), o Sistema de Informaçōes Hospitalares (SIH) e o Sistema de Informação da Atenção Básica (SIAB), o mais recente deles.

Carvalho (1997) fez uma análise desses principais sistemas com o objetivo de verificar as caracteristicas e potencialidades de cada um deles. Todos possuem aspectos positivos e negativos, que somente serão superados a partir do momento que forem utilizados e avaliados, possibilitando dessa forma revelar sua capacidade e seus limites. 
Com base nas leituras (Carvalho 1997; Mendes et al. 2000; Gouvêa et al. 1997; Mathias e Soboll 1998; França 2002), consideramos que os limites em certa medida são dados pela finalidade para as quais esses sistemas foram criados. Por exemplo, se um sistema foi criado tendo como principal finalidade o repasse de recursos, a principal limitação será dada por esse objetivo, porém, acreditamos que o uso do mesmo não deve ser descartado por esse motivo. Ao contrário, ele pode ser ampliado, contemplando os dois tipos de dados. Essa característica, que pode parecer negativa, por outro lado garante a regularidade do dado e sua amplitude.

Todos esses sistemas são de responsabilidade de diferentes órgãos do Ministério da Saúde:

O SIA e AlH são gerenciados pela SAS (antiga Secretaria de Assistência a Saúde e atualmente Secretaria de Atenção à Saúde);

- O SIM, SINASC, SINAN e SIAB são administrados pelo antigo CENEPI/FNS, atualmente Secretaria de Vigilância à Saúde (SVS).

O processamento e a divulgação dos dados, com exceção do SINAN que é de responsabilidade da SVS, ficam a cargo do DATASUS, órgão ligado à Secretaria Executiva do Ministério da Saúde.

A divulgação desses sistemas é feita via site do DATASUS ou CDROM. Em geral o site apresenta dados mais recentes que $0 C D$, dependendo do sistema.

A seguir, apresentamos um quadro resumo das principais caracteristicas desses sistemas: 
Tabela 1: Principais caracteristicas dos Sistemas de Informaçăo em Saúde.

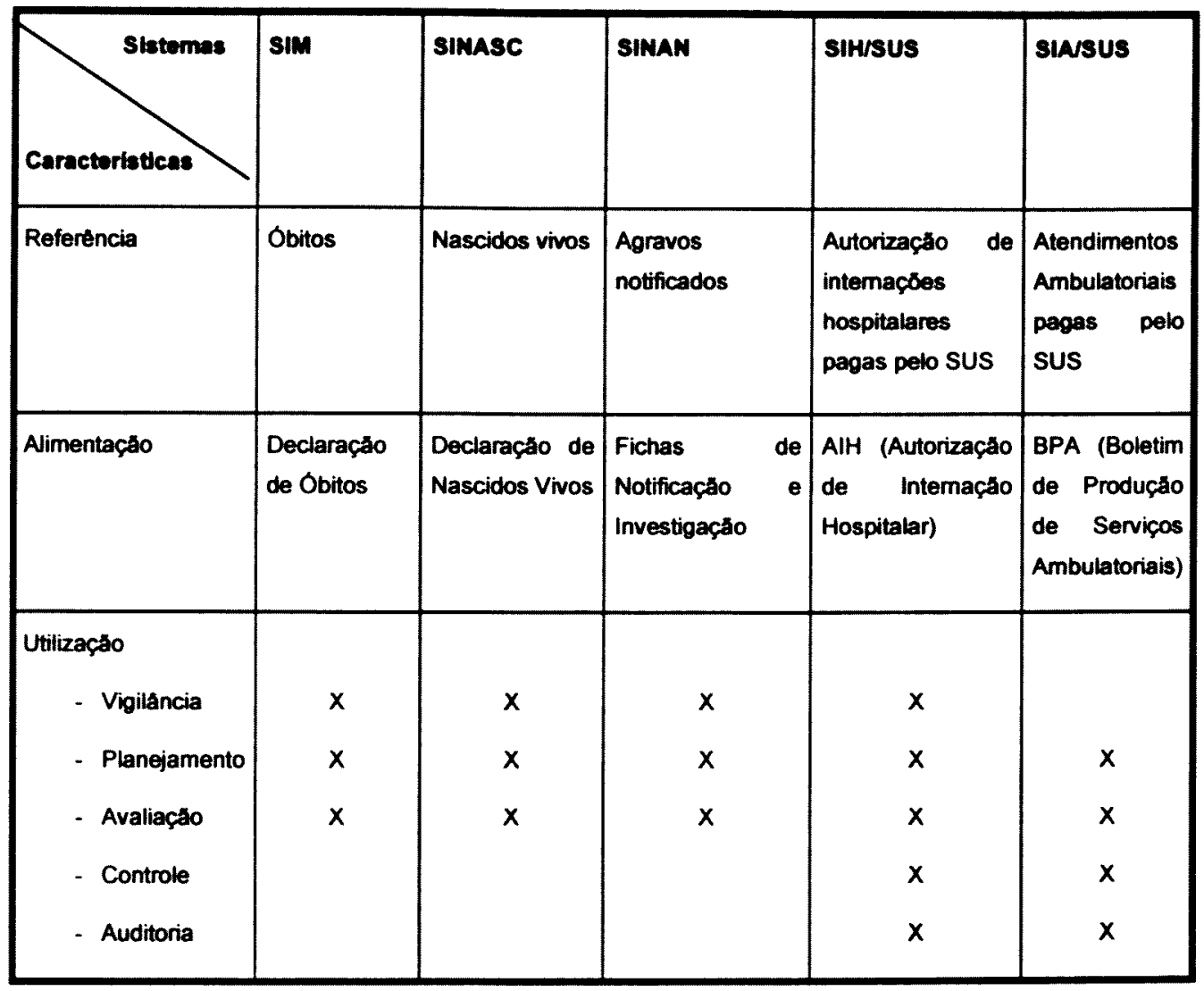

Fonte: Carvalho (1997)

Quando analisamos o histórico desses sistemas, apresentado por Carvalho (1997), observamos que cada um deles foi implantado em um momento distinto e atendendo a uma demanda específica, não havendo uma política nacional que orientasse a criação de um sistema de informaçăo em saúde no país, fato que ocorre posteriormente com a implantação do SUS. Quanto ao fluxo, os dados são coletados e processados em nivel local, geralmente municipal e depois encaminhados para o nível estadual e, por fim, federal, quando é consolidado e divulgado.

$\mathrm{Na}$ declaração de óbito, coletam-se os dados de mortalidade referentes ao local e data da ocorrência, identificaçăo do falecido e residência, tipo de óbito (se é fetal ou não), condições familiares (em caso de óbito fetal ou menores de 1 ano), causa e condiçōes de morte, 
identificação e firma do médico que assina a declaração, dados complementares, quando por causas externas, e cemitério de sepultamento.

Com os dados citados anteriormente é possível calcular, segundo Carvalho (1997, p.13), entre outros, os seguintes indicadores: Mortalidade proporcional por grandes grupos de causas determinadas e faixa etária; Coeficiente de mortalidade por causas específicas; Coeficiente de mortalidade infantil; Mortalidade proporcional por determinada causa em grupos específicos; Coeficiente de Mortalidade Materna; porcentagem de causas mal definidas no total de óbitos registrados; porcentagem de óbitos sem assistência médica por causas mal definidas no total de óbitos registrados e Coeficiente Geral de Mortalidade.

Carvalho (1997) ressalta como aspectos positivos do SIM a universalidade, padronização, comparabilidade e confiabilidade. Por outro lado, os aspectos negativos apontados foram o grande número de óbitos por sintomas Mal- Definidos, o preenchimento incorreto e a subnotificação.

No caso do SINASC, os dados obtidos via Declaração de Nascido Vivo (DN) são: o número da $\mathrm{DN}$, dados referentes ao cartório, local de ocorrência (domiciliar ou hospitalar), caracterização do recém-nascido, condições da gestação e parto, identificaçăo da mãe, nome do pai e responsável pelo preenchimento da DN .

Apesar de algumas restriçőes de acesso ao banco, com os dados coletados é possível calcular, segundo Carvalho (1997, p.21), principalmente, indicadores relacionados ao peso dos nascidos vivos, prematuridade, local de ocorrência e idade da mãe. Pode-se também calcular a taxa bruta de natalidade e fecundidade geral. Como aspectos positivos do SINASC a autora destacou a universalidade, variedade e propriedade da informação e operacionalização descentralizada. Entre os aspectos apontados como negativos, destaca-se a subnotificação como o principal deles.

O SINAN foi implantado oficialmente em 1993, fruto de um projeto piloto baseado no sistema de informaçōes para a notificação do cólera. Tem 
como objetivo a coleta de dados de doenças e agravos de notificaçăo compulsória.

A Ficha Individual de Notificação e a Ficha Individual de Investigação compõem o formulário de coleta de dados e, ao contrário do SIM e SINASC, a impressão, distribuição e numeração ficam a cargo do Estado ou município. A principal proposta desse sistema é que ele possibilite um acompanhamento local para a ocorrência de um evento de notificaçăo.

As variáveis são coletadas com as Fichas Individuais de Notificação e diferem dependendo do tipo de agravo, porém genericamente disponibilizam dados relacionados ao serviço que notificou, à identificação e caracterização do doente, à caracterização do agravo, o diagnóstico e evolução da doença. Com as variáveis coletadas é possível o cálculo dos seguintes indicadores: a taxa ou coeficiente de incidência, prevalência e letalidade.

Carvalho (1997) destaca que apesar de aspectos positivos do SINAN, como a universalidade e a possibilidade de diferenciação de riscos, não existe uma homogeneização quanto à coleta do dado, bem como a obrigatoriedade. Isto significa que podemos encontrar uma subnotificação distinta segundo a unidade da federação e o tipo de evento.

O SIA-SUS, implantado com a NOB 01/91, é baseado no Sistema de Informação e Controle Ambulatorial da Previdência Social (SICAPS). Porém, apesar das semelhanças, o novo sistema incorpora os serviços da rede pública. A partir da NOB/96, este Sistema desmembra as informações ambulatoriais de atenção básica e média complexidade, bem como as de alto custo/alta complexidade. Consta de variáveis referentes à identificação e caracterização das unidades, dados da mantenedora e dos profissionais e procedimentos.

Segundo Carvalho (1997), a partir dos dados desse Sistema é possivel calcular o "número de consultas médicas (ou de qualquer outro item de programação) por habitante, número de consultas médicas (ou de qualquer outro item de programação ou procedimento) por consultório (ou equipamento ou estabelecimento que 0 realiza) e número de 
exames/terapias realizadas pelo quantitativo de consultas médicas) ${ }^{n}$ (Carvalho 1997, p.43).

Segundo a autora, a agilidade na disponibilidade dos dados e a possibilidade de análises da oferta de serviços ambulatoriais para agrupamentos geográficos são os principais aspectos positivos do SIA. Porém, sua abrangência se restringe à rede do SUS. Como pontos negativos destaca a manipulaçăo dos procedimentos devido ao teto e a remuneração, bem como a impossibilidade de individualizar o atendimento segundo características da clientela, exceto para os procedimentos de Alto Custo/ Alta Complexidade 2 .

Consideramos, ainda, como importantes bancos de dados para a saúde, a Pesquisa por Amostragem Domiciliar (PNAD) e a Pesquisa de Assistência Médico-Sanitária (AMS), que são feitas pelo IBGE.

A PNAD, de periodicidade anual, é uma pesquisa das condições de vida e consumo, feita por amostragem, e fornece informações demográficas e socioeconômicas da população. Juntamente com a PNAD de 1998, foi realizado um levantamento sobre o acesso a serviços de saúde em suplemento especial de saúde.

A AMS, que já teve uma periodicidade anual, atualmente se realiza a cada dois anos. A ultima foi em 2002. É uma pesquisa que investiga os estabelecimentos de saúde no País tanto da rede pública quanto privada, com ou sem internaçăo, permitindo uma análise da oferta de serviços e equipamentos de Saúde.

Uma das críticas feitas atualmente ao SIS refere-se à polarização de pequenos sistemas. Basta uma visita ao site do DATASUS para verificarmos a quantidade de pequenos sistemas existentes. Além dos programas que apresentamos aqui, na página do DATASUS encontramos, entre outros: o Hiperdia (Sistema de Cadastramento e Acompanhamento de Hipertensos e

\footnotetext{
${ }^{2}$ Vale observar que quando a autora realizou sua pesquisa no banco não era possível individualizar os procedimentos de alto custo e alta complexidade, o que se tomou possivel somente a partir de 1996, com a criaçåo da Autorizaçăo de Procedimentos de Alto Custol Alta complexidade-APAC.
} 
Diabéticos), SisCam/SisColo (Sistema de Informação do Câncer da Mulher), SisPreNatal (Acompanhamento das gestantes do SUS), SI-PNI (Sistema do Programa Nacional de Imunização), Sisreg (Sistema de Informação sobre gerenciamento). Alguns desses poderiam inexistir se o Sistema de atenção básica fosse pensado para fornecer esse tipo de informação. Talvez a implantação e coleta de dados, via cartão do usuário, possa resolver esse tipo de problema.

A seguir apresentamos o Sistema de Informação de Internação Hospitalar, nossa principal fonte de dados nesse trabalho.

\section{O Sistema de Informação Hospitalar- SIH/SUS}

SIH/SUS tem sua origem no Sistema de Assistência MédicoHospitalar (SAMHPS), que foi criado no início da década de $80 \mathrm{com}$ o objetivo de pagamento dos serviços prestados pelos hospitais contratados (Mendes et al. 2000). No final dos anos 80 , outros serviços hospitalares foram incorporados, de maneira que, além dos hospitais contratados o Sistema passa a abranger os filantrópicos, os universitários e os de ensino. Com a implantaçăo do SUS, em 1991, passa a ser denominado SIH/SUS, porém permanece a lógica inicial, ou seja, os dados são coletados com o objetivo de pagamento. Este é considerado, por alguns autores, como o fator principal de limitaçăo de sua base (Carvalho 1997; Mendes et al. 2000).

O SIH/SUS caracteriza-se "por um modelo de financiamento do tipo prospectivo, fundamentado na estimativa de custos médios aplicados a uma unidade determinada (caso ou procedimento) e tendo uma base de cálculo pré definida" (Mendes et al. 2000, p.71). Não é um sistema universal, ou seja, não cobre todo o universo de internações hospitalares, mas sim as internações realizadas na rede pública que inclui hospitais ligados ao SUS. Estima-se que o SUS cubra em média de $70 \%$ a $80 \%$ das internações hospitalares no país (Gouvêa et al. 1997; Mathias e Soboll 1998; França 2002); porém, esta distribuição não é homogênea para os diferentes grupos de procedimentos, girando em torno de $90 \%$ nos casos de procedimentos de 
alto custo, năo cobertos na maioria das vezes pelos planos de medicina privada (Carvalho 1997).

O banco de Autorização das Internaçōes Hospitalares(AlH), compõem - Sistema de Informações Hospitalares do Sistema Único de SaúdeSIH/SUS. As AlHs, numeradas com uma validade de 4 meses, são distribuidas às Secretarias de Saúde estaduais pelo Ministério da Saúde. No ano de 1995 representavam $9 \%$ da população estimada pelo IBGE. O estado repassa para os municípios, baseado na Programação Pactuada e integrada (PPI). (Carvalho 1997)

As AlHs podem ser de dois tipos: AlH 1 e AlH5. As de tipo1 são utilizadas para todas as internações, enquanto que as de tipo 5 , ou continuidade, são utilizadas para o caso de pacientes crônicos ou psiquiátricos, que excedem os 107 dias permitidos na $\mathrm{AlH} 1$.

$\mathrm{Na}$ AlH encontramos informações referentes ao hospital, ao gestor, ao paciente, ao profissional médico envolvido no pedido de internaçăo, procedimentos, os exames e terapias realizados.

No fluxo da $\mathrm{AlH}$, no quadro apresentado a seguir, podemos observar que, nos 3 niveis de gestão, o sistema prevê critica dos dados a fim de evitar fraude e corrupção.

Tabela 2: Fluxo básico de autorização da internaçăo hospitalar

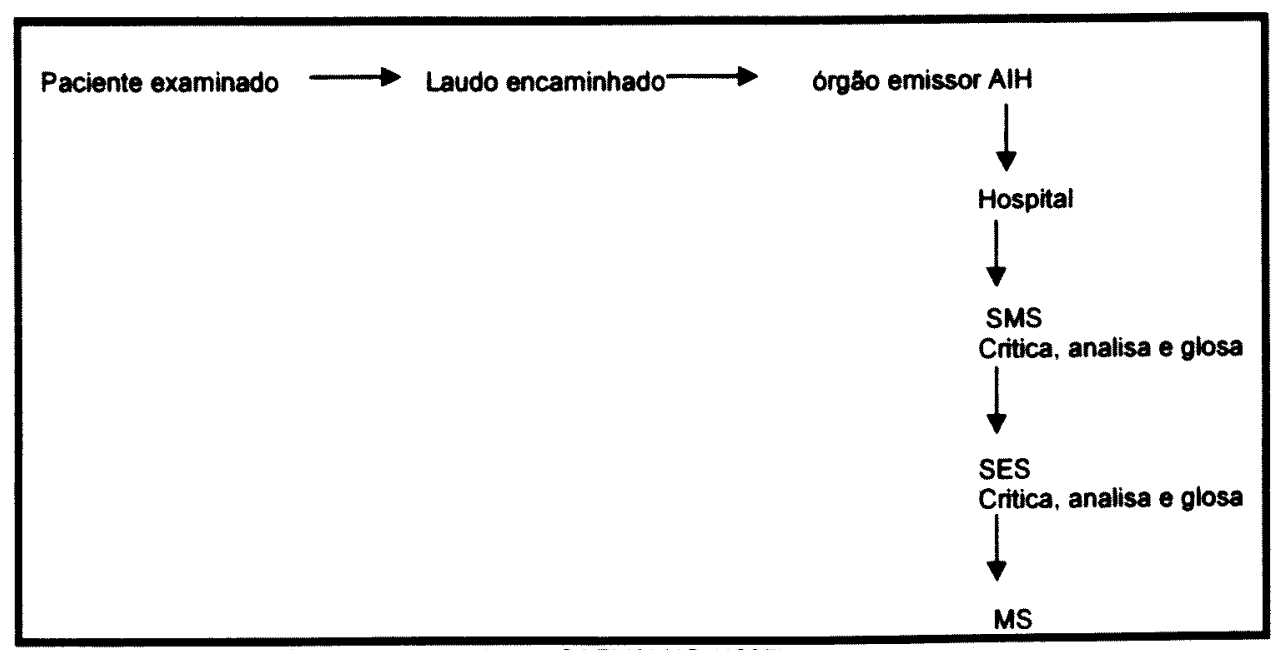

Fonte: adaptado de figura apresentada por CARVALHO (1997) 
O DATASUS, antiga Empresa de Processamento de Dados da Previdência Social (DATAPREV), é o órgão do Ministério da Saúde responsável pelo processamento e consolidaçăo de todos os dados.

\section{O SIH como fonte de dados}

O uso do $\mathrm{SIH}$, como fonte de informação, é diversificado. No levantamento realizado encontramos desde um enfoque administrativo, analisando o financiamento do SUS, bem como estudos que verificavam a confiabilidade desse banco como fonte de dados epidemiológicos, abordagens que avaliavam políticas de saúde e, ainda, investigações de morbidade especifica.

Scatena (2001) realizou um estudo do financiamento e perfil (volume e características) dos atendimentos hospitalares e ambulatoriais, de 1994 a 1998, em uma amostra de municipios do Estado do Mato Grosso, visando avaliar a política de descentralização. Em suas consideraçōes, o autor aponta para 0 aspecto positivo da descentralizaçăo na assistência ambulatorial, confirmada pelo aumento dos gastos per capita, porém ponderou que apesar disso o modelo de assistência médica curativa continua sendo privilegiado, pois, segundo ele, a assistência ambulatorial incorporou parte do atendimento que antes era hospitalar. Portanto, os recursos não privilegiaram a atençăo básica preventiva.

Entre trabalhos encontrados, que utilizam este banco como fonte de dados para estudos epidemiológicos, destaca-se a pesquisa realizada por Mendes et al. (2000), que consistiu em comparar duas fontes distintas de dados: o banco do antigo Centro Nacional de Epidemiologia (SINAN) com o SIH. Definiram, como objetivo principal, verificar a possibilidade da utilizaçăo do SIH/SUS como fonte complementar de informaçăo para doenças de notificaçăo compulsória. O período estudado foi de 1984 a 1998, buscando "descrever e interpretar aspectos relativos à magnitude e ao comportamento do problema obtido em um e outro sistema" (Mendes et al. 2000, p.68). 
No referido estudo foram incluidas as seguintes doenças: cólera, coqueluche, dengue, difteria, febre amarela, febre tifóide, hanseniase, hepatites virais, leishmaniose, menigites, poliomelite/paralisia flácida aguda, raiva humana, sarampo, AIDS, tétano (neonatal e acidental), tuberculose e, ainda, leptospirose.

Com este trabalho, apesar das críticas que são feitas ao $\mathrm{SIH}$ em relação à fidedignidade dos dados, concluíram que este sistema constitui-se em importante fonte complementar no acompanhamento das doenças citadas anteriormente, já que o sistema "mostrou-se ágil e com boa capacidade de detecção dos casos esperados tanto para as doenças que requerem muitos internamentos, como para as que pressupõem internamentos esporádicos" (Mendes et al. 2000, p.85).

O SIH também foi fonte de dados em trabalho realizado por Lebrão (1999), que pesquisou o perfil da morbidade hospitalar na região do Vale da Paraíba no Estado de São Paulo, usando duas bases de dados com informações referentes à saída hospitalar para os anos de 1975 e 1988 . A autora verificou uma mudança do perfil da morbidade hospitalar do ano de 1975 para 1988, porém considerou tarefa difícil definir as causas dessa mudança, já que, segundo ela, diferentes fatores contribuem para a determinação deste fenômeno, tais como fatores ecobiológicos, socioeconômicos, políticos, culturais, médicos e de saúde pública. Observou, também, uma mudança que estaria relacionada com as transições demográfica e epidemiológica, ou seja, uma mudança no perfil etário da população e no perfil da mortalidade, com reflexos no padrão de morbidade.

Nesse trabalho, em relação à principal causa de internação, assim como em 1975, em 1988 as complicações da gravidez, parto e puerpério foram as principais causas de internação, representando $27,1 \%$ e $26,6 \%$, respectivamente. Interessante ressaltar que em uma primeira exploração que fizemos da base de dados para o ano de 2000, o parto permanecia como a principal demanda do SUS, representando $24 \%$ das internações. A 
primeira hipótese que poderiamos levantar seria que essa diminuiçăo ocorreu devido à redução da fecundidade no país. Porém, é conclusão precipitada, para confirmá-la deveriamos antes descartar outras duas hipóteses: se esse fenômeno não é fruto do "teto" estipulado pelo Ministério ou do aumento de cobertura da saúde suplementar.

Lebrão verificou uma diminuiçăo dos registros de causas mal definidas, representando provavelmente uma melhora no diagnóstico e registro dos eventos. As doenças infecciosas e parasitárias perderam posições para as crônico-degenerativas. A autora observou ainda uma alteração da idade média dos pacientes que passou de 26,5 para 33,1.

Martins et al. (2001) utilizou o arquivo "Movimento Mensal das autorizaçōes de Internação Hospitalar", a fim de verificar o uso dos dados do SIH/SUS no ajuste de risco das taxas de mortalidade hospitalar e a utilidade do ICC (Indice de Comorbidade de Charlson) para o ajuste de risco de indicadores de desempenho. Foram selecionadas 40299 internações, ocorridas no município do Rio de Janeiro entre dezembro de 1994 e dezembro de 1996, com diagnóstico principal de pneumonia, insuficiência cardiaca congestiva, doença isquêmica do coração $e$ doença cerebrovascular. Utilizaram, como critérios de seleção, a alta freqüência e a ocorrência de óbitos. Da amostra selecionada, $52 \%$ das internaçőes foram masculina, e destas $50,5 \%$ foram óbitos.

Neste trabalho concluiram que, apesar da comorbidade ser um importante fator na prediçăo do risco de morrer, não foi conveniente, no caso das bases de dados do SIH/SUS, o uso desta variável devido à qualidade da informação diagnosticada. Vale lembrar que este campo não é de preenchimento obrigatório, para efeito de pagamento. Segundo os autores, a idade e o diagnóstico principal foram considerados os mais apropriados para este tipo de relaçăo. Em quanto à idade, constaram que $75,9 \%$ dos pacientes da amostra tinham idade superior a 50 anos.

Apesar das limitações da base de dados, que é de uso administrativo, os dados são coletados com um enfoque de faturamento, e os autores não 
descartam a sua utilizaçăo para estudo epidemiológicos e recomendando uma melhora de qualidade, na variedade de eventos coletados.

Em relação à confiabilidade de diagnóstico no formulário de Autorização de Internação Hospitalar, Mathias e Soboll (1998) realizaram estudo na cidade de Maringá, no Estado do Paraná, comparando a informação do prontuário com as da AlH. Concluíram que, apesar de alguns fatores interferirem nas razőes de discordância entre o prontuário e a $\mathrm{AlH}$ entre eles "a falta de treinamento para a codificação do diagnóstico e o sistema de pagamento das internações hospitalares" (Mathias e Soboll 1998, p.526)- para o ano de 1992, no município de Maringá, os dados poderiam ser utilizados com um certo grau de confiabilidade.

Mathias e Soboll (1998, p.530) em seu trabalho citam estudo semelhante realizado por Veras e Martins e Travassos (1998) no município do Rio de Janeiro, no qual, os autores concluíram que a qualidade dos dados foi superior ao que eles esperavam. Porém, alertam que os estudos de morbidade devem "observar os diagnósticos em categorias mais agregadas".

Ainda sobre a confiabilidade do SIH-SUS, encontramos estudo realizado por Simőes (2000) em sua dissertação de mestrado, na qual comparou as internações do banco de $\mathrm{AlH}$ com os dados dos prontuários da Santa Casa de São Paulo, a fím de qualificar o SIH como fonte de informação em saúde. As variáveis utilizadas do banco AlH foram: data de apresentação, número da $\mathrm{AlH}$, bairro, cidade, estado, data de nascimento, sexo, enfermaria, leito, procedimento solicitado, data da emissão, procedimento autorizado, procedimento realizado, especialidade, data de internação, data de saída, diagnóstico principal, diagnóstico secundário e tipo de alta. Em relaçăo ao banco de prontuários foram considerados: data de internação, registro geral, procedência, sexo, idade, código da idade, os códigos de diagnósticos, condiçð̃es e data de saída.

O autor relacionou os dois bancos utilizando as variáveis registro geral e data de entrada, visando identificar as reinternações, que resultaram 
em 628, do total de 31084 internaçōes da amostra. Quanto à análise das variáveis selecionadas considerou que:

- As variáveis de identificaçăo (sexo idade, procedência, data de entrada, data de saída e tipo de evolução) refletiam o perfil de atendimento da instituição.

- Para diagnóstico principal, de acordo com a classificação por capitulos das CID-9, a maior diferença encontrada foi de quase $2 \%$ para as causas relacionadas ao aparelho respiratório, o que o autor considerou de "pouca interferência", Porém, quanto maior a desagregação, acentuam-se as diferenças entre os dois bancos.

- Quanto ao diagnóstico secundário, observou-se que em 4\% das internações do banco de $\mathrm{AlH}$, este substituiu o diagnóstico principal, em comparaçăo com os dados do prontuário.

- O tempo de permanéncia apresentou uma maior concordância para períodos inferiores a 5 dias.

Apesar das diferenças encontradas, Simões considerou válido o uso da AlH como fonte de informação em saúde.

Uma das limitações do banco AlH é a impossibilidade de recuperar os caso de reinternação. Preocupados com esse problema, Portela et al. (1997) realizaram estudo para a criação de um algoritmo capaz de recuperar as internações, partindo do banco de $\mathrm{AlH}$, ou seja, para "construir um novo banco cuja unidade de observação fosse a internação hospitalar" (p.772), descartando assim as reinternaçőes.

Após a aplicação do algoritmo no universo de internações do município do Rio de Janeiro, constaram que, entre as diferentes especialidades, as psiquiátricas foram as que sofreram maior redução. Das 107304 AlHs dessa especialidade, que representaram $10 \%$ de $\mathrm{AlH}$ no ano de 1995, após a aplicação do algoritmo reduziu-se para 27712 (3\%) internações. Para os hospitais com predomínio de clínica, cirurgia, 
obstetrícia e pediatria o número de internações foi quase o mesmo do número de AlHs.

O banco de $\mathrm{AlH}$, como fonte para avaliação da produção e qualidade da assistência, foi usado por Gouvêa et al. (1997), com o objetivo de analisar a tendência da assistência hospitalar no Estado do Rio de Janeiro. Esses autores realizaram um estudo comparativo da assistência para hospitais públicos, universitários e privados credenciados pelo SUS, utilizando "modelos estruturais de séries temporais, baseadas na decomposição dos componentes de interesse, como tendência, sazonalidade e irregularidade" (Gouvêa et al. 1997, p.601).

Apresentaram dois tipos de problemas para utilização do banco: a insuficiência do dado e a qualidade. Quanto à primeira limitação, que consideraram a mais importante, referiram a falta de dados que possibilitasse uma classificação da gravidade dos casos. Em relação à qualidade, consideraram as informaçōes sócio-demográficas mais confiáveis do que as informações clínicas.

Já entre as informaçőes clínicas, classificaram o procedimento realizado, ocorrência de óbito e as transferências como variáveis mais confiáveis do que o diagnóstico principal. E concluíram que, no caso estudado, ocorria problemas sérios na qualidade da atenção hospitalar no Estado do Rio de Janeiro e que, apesar das limitações do banco, o mesmo é útil para estudos com esse objetivo.

O SIH também foi fonte de informação em trabalho feito por Schramm e Szwarcwald (2000) sobre a mortalidade neonatal e a natimortalidade, com o objetivo de comparar estes tipos de mortalidade nas unidades da federação e países selecionados pelas autoras.

Em sua pesquisa, as autoras observaram, em estados do Norte e Nordeste, baixos valores de mortalidade neonatal e natimortalidade em comparaçăo com outros Estados e paises. Porém, nessas regiōes são encontradas as maiores proporções de partos domiciliares, ou seja, uma 
menor cobertura dos partos e uma baixa utilização de serviços no período neonatal.

Nessas regiōes também foram encontradas as maiores discrepâncias entre o procedimento parto e o tempo de permanência, o que sugere falhas na atençăo à parturiente. Tal fato causou surpresa, pois supostamente, essa incompatibilidade deveria ser motivo para a rejeição da $\mathrm{AlH}$, portanto, do seu não pagamento. Uma das dificuldades encontradas para um aprofundamento dos estudos foi a falta de dados sobre o peso e a idade gestacional que, embora coletados, não são disponibilizados.

Quanto à qualidade, nos estados do sul e sudeste, que apresentaram maior cobertura do sistema, observou-se altas taxas de mortalidade neonatal, em comparação com as de países desenvolvidos. Diversos autores, apesar de fazerem observaçōes quanto à confiabilidade dos dados, consideram que as bases deveriam ser melhor aproveitadas tanto em estudo acadêmicos, quanto na tomada de decisões por parte dos gestores de saúde.

Segundo Almeida (1996, p.11), o Brasil possui um sistema mais sofisticado do que aquele existente na França, "com maior detalhamento de informações gerenciais e epidemiológicas, apresentando um sistema com maior agilidade quando comparado ao Francês".

Independente das críticas feitas em relação à qualidade dos dados, já que são tentadoras as fraudes do sistema, o banco AlH apresenta-se como uma importante fonte de informaçăo para o conhecimento do perfil dos atendimentos na rede hospitalar e com certa agilidade do sistema.

Quanto a fraudes, Carvalho (1997) considera que em cada ano novas críticas são incorporadas no sentido de eliminá-las, e o problema da fraude não é do sistema de informação, mas da incapacidade do sistema de saúde, ou seja, do Estado, na implementação de medidas para garantir a qualidade da informação e do cuidado prestado.

Diante das evidências apresentadas, podemos considerar que, apesar de algumas críticas que são feitas ao Sistema de Informação Hospitalar, 
devemos reconhecer que o mesmo se constitui em uma importante fonte de dados que não deve ser descartada em estudos sobre morbidade, sobretudo porque as informaçōes disponíveis são de grande importância tanto gerencial, quanto epidemiológica. Além disso, com a potencialidade de informaçס̋es, como as obtidas no SIH/SUS, é possivel definir politicas para a assistência hospitalar do País. 


\section{Capitulo II Gênero e morbidade}

\section{Entendendo o conceito de gênero como categoria de análise}

Para analisarmos a demanda hospitalar no Sistema Único de Saúde no ano de 2002, usando o conceito de gênero como a principal categoria de análise, necessitamos esclarecer a nossa opção teórica do conceito de gênero aqui utilizado. O processo saúde/doença não tem apenas uma determinação biológica, mas também social, e os papeis definidos socialmente implicam um estilo de vida próprio para os dois sexos, que reflete em maneiras diferentes de adoecer e cuidar.

Louro (1996), quando apresenta as idas e vindas do conceito de gênero, coloca que a opçăo por ele significa "uma decisão de ordem epistemológica e (...) teórica". Complementando o que diz a autora, acreditamos que essa opção vai além da academia, por entender a grande contribuição que o mesmo trouxe para melhor se compreender a condição feminina na atualidade.

A principio, pode parecer tarefa fácil estudar a morbidade usando o recorte de gênero, já que o termo é recorrente tanto nos meios acadêmicos quanto fora dele. Entretanto, se não tivermos claro o conceito para usá-lo como categoria de análise, corremos o risco de cair em uma armadilha, ou seja, aplicá-lo como sinônimo de sexo.

Consciente desse perigo e visando escapar dessa armadilha, buscamos bibliografia necessária para o entendimento do conceito, porém acabamos com a sensação de que não existe outro campo do conhecimento tão controverso quanto esse. Foi incrível verificar a variedade de interpretações e discussões sobre o tema que, em tão pouco tempo ${ }^{3}$, vai desde abordagens mais essencialistas até as que tentam descartar

\footnotetext{
${ }^{3}$ A preocupaçăo com a diferença entre homens e mulheres ganhou maiores proporçőes a partir dos anos 60 com o movimento feminista e o conceito começou a ser mais discutido nos anos 80 .
} 
totalmente a dimensão biológica em favor da cultural, passando por aquelas que buscam uma intermediação entre o biológico e social.

Porém essa característica não foi obstáculo, ao contrário, pois concordamos com Louro (1996), que considera a diversidade de enfoques dados a esse conceito um "fator de vitalidade" e, se por um lado, pode propiciar uma certa instabilidade, por outro, "incita a um constante questionamento e autocrítica" (Louro 1996, p.7). Mesmo por que, no campo cientifico, é cada vez mais difícil encontrarmos uma verdade eterna, absoluta e duradoura, tudo a todo o momento se transforma, inclusive o conceito de gênero.

Nossa primeira constataçăo parte da idéia que não se pode falar de gênero sem falar de feminismo, pois foi dentro dessa corrente que o conceito surgiu e ganhou força. Em um primeiro momento, os estudos de gênero tinham como foco central a mulher, principalmente os estudos feministas, na tentativa de "constituí-la como o sujeito-objeto dos estudos", porém mais recentemente os homens foram incorporados, ampliando-se o enfoque para "os processos de formação da feminilidade e da masculinidade, ou os sujeitos femininos e masculinos" (Louro 1996, p.7).

Em relação à categoria gênero, vamos encontrar enfoques psicanalíticos, antropológicos, sociológicos, históricos e feministas. 0 emprego do termo gênero, não é recente, tampouco se constitui em um campo único do conhecimento. Engels há mais de 150 anos já tratava do tema (Saffioti 1992), porém o mesmo ganhou espaço e distintas abordagens nas últimas décadas, como conseqüência do movimento feminista e perspectivas teóricas como o pós-estruturalismo.

Para responder nossa questão de quando e como surge o conceito de gênero utilizamos duas autoras, Barbieri (1991) e Scott (1995). Ambas concordam que o termo começou a ser utilizado pelas feministas, a partir dos anos 60 . Além da origem do uso do termo, nos trabalhos dessas autoras encontramos as definições de gênero utilizadas por elas, além de um 
balanço sobre o uso do conceito por diferentes correntes teóricas, com categoria de análise.

Scott (1995) reconhece que estudos no século XVIII até o começo do século $X X$ usavam analogias com a oposição masculino/feminino. Porém, foi somente no fim do século $X X$ que surgiu uma "preocupação teórica com gênero como categoria analítica". Tal fato talvez explique, segundo ela, a dificuldade de algumas feministas na incorporação desse conceito, contudo reconhece que o mesmo não é a-histórico e surge em um momento de grande efervescência epistemológica.

Para essa autora, a utilização mais recente do termo gênero foi iniciada pelas feministas americanas,

(...) que queriam enfatizar o caráter fundamentalmente social das distinçōes baseadas no sexo. A palavra indicava uma rejeiçăo do determinismo biológico implícito no uso de termos como sexo ou diferença sexual. O termo gênero enfatizava igualmente o aspecto relacional das definiçōes normativas da feminilidade. Aquelas que estavam preocupadas pelo fato de que a produçāo de estudos se centrava nas mulheres de maneira demasiado estreita e separada, utilizaram o termo gênero para introduzir uma nova noção relacional em nosso vocabulário analítico. Segundo esta visão, as mulheres e os homens eram definidos em termos recíprocos e năo se poderia compreender qualquer um dos sexos por meio de um estudo inteiramente separado (72).

O objetivo principal de Scott (1995) foi apresentar o uso dessa categoria na análise histórica. Para isto referencia as diferentes correntes e suas limitações, e finalmente, elabora a sua definição. Segundo ela, uma ala das pesquisadoras feministas acreditava que gênero, raça e classe social, seriam três categorias fundamentais para escrever uma nova história, porém, estas não são paritárias. Gênero e raça, possuem um fundamento distinto de classe, não havendo clareza ou causalidade econômica, presentes nessa última. Para Scott (1995), gênero “implicou uma ampla 
gama tanto de posições teóricas quanto de simples referências descritivas às relaçőes entre os sexos" (p.73).

Scott (1995) considera que, apesar

da variedade de abordagens na análise do gênero, essas podem ser resumidas a três posições teóricas. A primeira, uma tentativa inteiramente feminista, empenha-se em explicar as origens do patriarcado. A segunda se situa no interior de uma tradição marxista e busca um compromisso com as críticas feministas. A terceira, fundamentalmente dividida entre o pósestruturalismo francês e as teorias anglo-americanas de relação do objeto (object-relation theories), se inspira nessas diferentes escolas de psicanálise ${ }^{4}$ para explicar a produção e reprodução da identidade de gênero e sujeito (Scott 1995, p.77).

A definição dessa autora se subdivide em duas proposições:

1- "gênero é um elemento constitutivo de relaçōes sociais baseadas nas diferenças percebidas entre os sexos e,

2- o gênero é uma forma primária de dar significado às relações de poder" (Scott 1995, p.86)

Essa definição se inter-relaciona com quatro elementos:

1- "(...) os símbolos culturalmente disponíveis que evocam representações simbólicas e, com freqüência, contraditórias.

2- (...) os conceitos normativos que expressam interpretaçð̃es dos significados dos símbolos, que tentam limitar e conter suas possibilidades metafóricas.

3- A pesquisa histórica que (...) deve incluir uma concepção de política, bem como uma referência às instituições e à organização social.

\footnotetext{
${ }^{4}$ A autora se refere à corrente psicanalitica Anglo-americana em contraposição ao pósestruturalismo francês, enquanto a primeira se baseia nas teorias de relação de objeto, a segunda centra sua análise na linguagem (Scott 1995, p.81).
} 
A primeira parte de sua concepção de gênero inclui esses quatro aspectos citados e nenhum pode operar sem o outro, porém podem nāo ocorrer simultaneamente. A principal preocupação da autora foi teorizar o conceito de gênero que, segundo ela, "é uma forma primária de dar significado às relações de poder (...), é um campo primário no interior do qual, ou por meio do qual, o poder é articulado" (Scott 1995, p.89).

Sobre o problema da polarização gênero masculino e feminino, Joan Scott (1995) alerta sobre a necessidade de desconstrução dessa lógica binária, pois a mesma oculta a diversidade existente por trás dos dois gêneros. Somente um conceito que não seja universal possibilita a inclusão das outras diferenças.

A desconstrução ajuda-nos a entender que a oposiçăo dos gêneros masculino e feminino é, na verdade, uma interdependência, já que um pólo contém o outro (Louro 1995). Na análise de Scott (1995), a questăo do poder está explicita na sua conceituação de gênero, e nela percebemos uma forte influência de Foucalt, ou seja, o poder não está presente no Estado, mas difuso em outras relaçōes dentro da sociedade.

Em outros/as autores/as também vamos encontrar a discussão desse tema. Barbieri (1991) exemplifica esse poder difuso, quando diz que os homens controlam o corpo e o desejo da mulher porque, sem isso, não teriam como serem pais, ou ainda, como uma forma de garantirem com um pouco de certeza a paternidade de seus filhos. Enquanto no texto de Scott (1995) encontramos uma preocupaçăo com o conceito de gênero como categoria de análise histórica, no artigo de Barbieri encontramos seu emprego como categoria sociológica.

Para Barbieri (1991), nos anos 60, o movimento feminista buscou um entendimento e uma explicação para a subordinação das mulheres e constatou que năo havia, nas ciências sociais e humanas, estudos que explicassem esse fenômeno. Nesse contexto a primeira hipótese que emerge, segundo a autora, é que a subordinaçăo das mulheres era fruto de 
uma relação de poder que não se concentrava na figura do Estado, mas estava disperso na sociedade. Nesse momento, segundo a autora, surge um movimento no sentido de refutar tudo o que tinha sido feito ou discutido até então, reconhecendo apenas autores como Engels e Simone de Beauvoir, os únicos considerados por essa corrente como "objetivos" e "bem intencionados".

Na tentativa de entender as diferenças de poder, entre homens e mulheres, e buscando construir uma teoria, as feministas identificaram a subordinação como produto do patriarcado, portanto, para liberar as mulheres era necessário destruir essa ordem social. Este tipo de pensamento rapidamente se estendeu, porém sem uma reflexăo e um debate que propiciasse um aprofundamento do tema, o que gerou, segundo Barbieri (1991), um conceito vazio, útil politicamente, mas limitado como modelo explicativo.

Paralelamente, um outro grupo de feministas, visando suprir a carência de dados, realizou um caminho mais empírico buscando estudar principalmente as condiçōes de vida das mulheres, que foram denominados de "estudos sobre as mulheres". Dentro desse grupo, era possivel distinguir duas posturas: "uma centrada na mulher como objeto de estudo, que visava produzir informação e hipóteses sobre as condições de vida e de trabalho femininas; e outra, que privilegiou a sociedade como geradora da subordinaçăo das mulheres" (Barbieri 1991, p.28) (tradução nossa).

O segundo grupo passa a basear-se em duas proposiçסes:

1- " ....a subordinaçăo das mulheres é produto de determinadas formas de organizaçăo e funcionamento das sociedades. Portanto, é necessário estudar a sociedade ou as sociedades concretas.

2- ...não se avançará estudando somente as mulheres, o objeto é mais amplo. Requer analisar em todos os níveis, âmbitos e tempos as relações de mulher-homem, mulher-mulher $e$ homem-homem" (Barbieri 1991, p.29). (traduçăo nossa). 
Como fruto dessas discussőes surge o termo gênero como categoria social, contrapondo-se à concepçăo de "sexo anatômico e físiológico".

Barbiere (1991) distingue três perspectivas ou orientaçōes teóricas distintas:

1- "Autores/as que concebem o gênero como um sistema hierarquizado de status e prestígio social". Para a autora, essa corrente está ligada ao funcionalismo sociológico e à teoria psicanalítica do eu que "dão maior peso à socializaçăo como aprendizagem de papéis que se repetem ao largo da vida"

2- Corrente de influência marxista, denominada "relações sociais de sexo, que privilegiam em sua análise a divisão social do trabalho como núcleo motor da desigualdade".

3- Finalmente, "a perspectiva que considera os sistemas de gênero como sistemas de poder resultado de um conflito social" (Barbieri 1991, p.31). (tradução nossa)

Barbieri (1991) declara sua opçăo por essa última, já que considera a mais apropriada para analisar o contexto latino-americano.

Na discussão apresentada pela autora, destacamos uma idéia que consideramos fundamental para este trabalho. Existem "homens e mulheres em diferentes contextos sociais e culturais que devem ser delimitados" (Barbieri 1991, p.34). (tradução nossa). Partindo desta idéia, consideramos que apesar dos padrōes definidos, năo existe uma identidade feminina única, assim como também năo encontramos uma única identidade masculina (Adorno e Betini 2000).

Este tema também aparece em autores que trabalham a relação sexo e raça, como Azerédo (1994) e Bairros (1995), que tratam da questão da incorporação de outras diferenças aos estudos de gênero, como por exemplo a questão étnica. A primeira autora, partindo deste enfoque busca 
entender as diferenças de experiência entre o feminismo americano e o brasileiro.

Para ela, no Brasil, existe uma dificuldade em analisar gênero "considerando simultaneamente outras categorias de subordinação" (Azeredo 1994, p.207). Isto tendo em vista a idéia presente da transversalidade de gênero. Esta incorporação tem importåncia quando lutamos por uma sociedade mais igualitária. Assim, caminhamos nesse sentido, quando fazemos o exercício de resgatar outras diferenças sociais na discussão (Azeredo 1994).

Para Barbieri (1991), a idéia de uma diversidade dentro da identidade masculina e feminina, relaciona-se com o ciclo de vida, que também é uma construção social. Segundo ela, a principal etapa é aquela em que homens e mulheres estão em sua plena capacidade de reprodução, em que se pode observar os elementos-chave das relações que prevalecem no sistema de gêneros de uma dada sociedade.

Anterior a essa etapa reprodutiva, encontra-se aquela em que se moldam as crianças dentro do sistema de gênero dominante. Posterior a ela, está aquela em que poderemos observar a manutençăo ou o desmantelamento dessas normas. Outro elemento que interfere nessa construção, é a organização da vida doméstica, devendo se considerar a composiçăo, tamanho e ciclo de vida familiar que, com certeza, geram efeitos nas diferentes posiçōes e papéis que cumprem homens e mulheres, nesse contexto. Além disso, as condiçōes econômicas, as diferenças regionais e locais, o contexto étnico-cultural devem ser considerados nessa diferenciação.

Entendemos que essas diferenciações, principalmente durante o ciclo de vida, determinam a posiçăo ocupada pelo homem ou pela mulher no sistema de gênero de uma dada sociedade, que reflete acesso diferenciado a bens ou serviços. Para Barbieri (1991, p.42), ainda existem vazios que nos impedem de dizer que exista uma teoria a respeito da categoria gênero, o principal deles é em relaçăo ao objeto, já que as investigações săo muito 
mais voltadas para as mulheres e nåo geraram informações e análises, desde uma perspectiva masculina.

Para nós, a divisão social do trabalho que aparece no estudo de Barbieri (1991) e de outros/as autores/as, também reflete diferenças no estilo de vida e em práticas de risco ou năo. Entendemos que, à medida que muda essa dinâmica, a tendência é a de ocorrer uma mudança da vulnerabilidade (fatores de risco) de homens e mulheres e, portanto, da morbidade.

No sentido de desvendar os rumos da discussão e os usos do conceito gênero em estudos no Brasil, o trabalho de Heilborn e Sorj (1999) é esclarecedor, ainda que segundo as autoras não tenha sido um balanço exaustivo. Se por um lado, observamos algumas semelhanças no rumo da institucionalização das discussōes deste tema no Brasil, por outro lado, descobrimos que a experiência nacional apresentou algumas características distintas. Enquanto nos Estados Unidos e Europa as feministas assumiram uma posição mais radical na relaçăo com a academia, a realidade brasileira impôs uma outra postura para as feministas, que usaram uma estratégia de "enfrentamento" mais moderada e articulada com o movimento de esquerda, concentrando seus esforços na área da pesquisa social.

Desta forma, as feministas brasileiras em vez de criarem espaços alternativos de atuação dentro ou fora da academia, como as norteamericanas, buscaram espaço e reconhecimento dentro da própria instituição. "Os estudos sobre a mulher, Estudos de Gênero ou de Relaçőes de Gênero foram as fórmulas encontradas para institucionalizar a reflexão impulsionada pelo diálogo com o feminismo na academia brasileira." (Heilborn e Sorj 1999, p.187)

A partir da década de oitenta observa-se uma gradativa substituição do termo mulher, uma categoria empírica/descritiva, pelo termo gênero, uma categoria analítica, como identificador de uma determinada área de estudos no país. (...) Os homens passaram a ser incluidos como uma categoria de análise empírica 
a ser investigada nesses estudos e uma abordagem que focaliza a estrutura social mais do que os indivíduos e seus papéis sociais foi favorecida. (Heilborn e Sorj 1999, p.188)

A adoção desse novo conceito a partir dos anos 80 , que também não foi traumática como nos EUA, favoreceu a aceitaçăo desses estudos no meio acadêmico. As autoras destacam o apoio das agências financiadoras como elemento favorável ao prestígio de pesquisas nessa área, pois os investimentos desses órgăos contribuíram para o reconhecimento da relevância desses estudos pela comunidade cientifica.

Segundo as autoras, é tarefa difícil avaliar o "grau de institucionalizaçăo" desses estudos na área de ciências sociais, já que a incorporação desse tema foi diferenciada dentro dessa área do conhecimento, sendo muito maior no caso da antropologia do que das ciências políticas.

Uma outra característica destacada é a alteração da "composição sexual", já que se observa um aumento do nủmero de homens interessados pelo tema e, principalmente, a incorporação de temas relativos a masculinidade e à sexualidade.

Quanto ao embate teórico, as autoras destacam que, no Brasil, recebemos influência tanto da corrente anglo-saxă, quanto da investigação francesa. Mas, devido a uma "antropologizaçăo" das ciências sociais no País - "uso da categoria gênero tornou-se hegemónico". Porém, năo arriscam afirmar por quanto tempo permanecerá essa hegemonia, frente à crise dos paradigmas nas ciências sociais que podem minar a capacidade "heurística desse conceito" (Heilbom e Sorj 1999, p.196). O funcionalismo, principalmente nos Estados Unidos, e o marxismo, foram as duas correntes teóricas da sociologia que mais influenciaram os estudos de gênero.

O funcionalismo contribuiu, por seu lado, com conceitos como "papel sexual" e "status",

supriu estudos de gênero com a hipótese de que as diferenças sexuais săo mais centrais na instituiçăo familiar do que 
em qualquer outra instituiçăo social e que os arranjos de gênero funcionam primordialmente para assegurar a reprodução social; e as análises sociológicas das relaçōes de gênero, sustentadas no conceito de papéis sexuais, desafiaram as visőes essencialistas da biologia e da psicologia sobre as identidades humanas na medida em que facilitou 0 reconhecimento de que os indivíduos se constroem por intermédio da vida social. (Heilborn e Sorj 1999, p.197)

Apesar das contribuições citadas, as influências funcionalistas ao debate foram consideradas negativas, legitimando a subordinação das mulheres na esfera familiar, pois, ao se explicar às diferenças de gênero via papeis sociais, limitava-se o "foco da análise ao comportamento individual e diminuía o seu poder de explicaçăo da dinâmica social mais ampla" (Heilborn e Sorj 1999, p.198). A teoria marxista, por outro lado, contribuiu com uma análise de gênero mais ampla, fora da esfera familiar. Porém, evidenciava seus limites nas interpretaçőes das relações de gênero no interior de outras instituiçőes sociais.

Uma outra característica dos estudos da sociologia de gênero apontado pelas autoras, refere-se ao fato da grande maioria dos trabalhos tratarem da esfera "privada" ou de instituições de mulheres, fato que vem se modificando mais recentemente.

No texto de Heilborn e Sorj (1999), foi possivel resgatar a origem de uma outra corrente que utiliza a denominação sistema de gênero, que nasce dentro da antropologia, e que procurava

demarcar os dois niveis diferenciais que a condiçăo sexual comporta" (...) O ponto crucial desse momento da reflexăo era justamente o papel que a reprodução ocupa como elemento estruturador ou não de significados e de posiçס̃es sociais atribuídos diferencialmente aos dois sexos. (...) O argumento central à idéia de sistemas de sexo-gênero é a transformação da diferença sexual 
operada pela cultura numa relação de opressão (denominada por Rubin de domesticação da mulher) (p.199).

Heilborn e Sorj (1999) destacam que é dentro da própria antropologia que vem à tona uma das principais críticas ao conceito de gênero nas ciências sociais, apresentado por Strathern, que surge quanto ao questionamento no sentido de considerar que as interpretaçס̃es baseadas nesse conceito, feitas pelas diversas correntes teóricas, generalizam e não consideram as diferenças na construção social de identidades nas distintas sociedades, e acabam por utilizar modelos de análise construídos com base em sociedades ocidentais.

No final dos anos 80 ganham espaço os estudos sobre sexualidade, que contribuem com a discussão de gênero colocando em questão a relação entre "construção cultural e diferença anatômica" (Heilborn e Sorj 1999, p.202), que passa a ser desnaturalizada em contraposição à corrente essencialista.

O que parecia ser tarefa fácil no trabalho, ou seja, definir o conceito de gênero, em determinado momento de nossas leituras descobrimos que não o era, pois existe nesse campo do conhecimento um intenso debate entre as diversas correntes, năo havendo ainda consenso quanto a sua utilização. O uso do termo gênero foi questionado como "falácia", pois "sustenta-se sobre um pilar problemático:"natureza"; também ela uma idéia historicamente produzida" (Heilborn e Sorj 1999, p.201).

Em linhas gerais, a idéia presente é a de que, enquanto as diferenças biológicas se relacionam ao sexo, a categoria gênero pode ser entendida como uma construção social. Portanto, devemos compreendê-la dentro de um contexto sócio-cultural, e sem perder a perspectiva histórica. Acrescentase $a$ isso que năo existe uma identidade única de gênero masculino e feminino.

Partindo desta noçăo, na qual a cultura proporciona elementos para entender as diferenças entre os sexos, é possível concluir que ao redor das diferenças biológicas sexuais se constrói uma desigualdade social entre os 
membros de cada sexo, colocando as mulheres em uma situação desvantajosa em, praticamente qualquer, contexto social e cultural.

Louro (1996) alerta para o fato de que, se por um lado, não podemos descartar "o caráter social das diferenças entre homens e mulheres", por outro, não podemos esquecer que gênero envolve "corpos sexuados", portanto, tem também uma "dimensão e uma expressão biológica" (...) havendo "uma estreita e continua imbricação do social e do biológico" (11).

Diante disto, quando falamos em relações de gênero, assim como outros autores, consideramos importante ressaltar que não nos referimos ao sexo biológico, mas sim à construção social de cada sexo dentro de uma sociedade e suas implicações, como o acesso diferenciado à informação, saúde, educação e ao poder de negociação dentro de uma relação.

\section{Gênero e Saúde: do controle da natalidade aos direitos sexuais e reprodutivos}

No campo da saúde pública, crianças e mulheres sempre foram o foco de atenção. A preocupação com esses dois grupos vem desde a "organização das cidades e do incremento da industrialização", passando pelas "políticas higienistas, sanitárias e preventivas" (Meyer 1998, p.24), para garantir a reprodução social. Por outro lado, os homens foram objeto de preocupação enquanto força de trabalho, contemplada nas políticas de Saúde do Trabalhador. As políticas de saúde da Mulher no Brasil centravam-se na Saúde Materno-Infantil. Portanto, a preocupação com a mulher se justificava pela sua capacidade reprodutora, em determinados momentos para estimular a procriação, em outros para controlar o corpo reprodutor.

Ao longo dos anos, a discussão foi se ampliando e o conceito de saúde reprodutiva foi ganhando o espaço em relação ao de do controle de natalidade, visando alcançar toda a complexidade do tema e melhorar a proteção aos direitos humanos. 
Segundo Galvão (1999), o conceito de saúde adotado pela OMS foi se modificando desde sua primeira versão em 1948, ocorrendo o mesmo com os conceitos de saúde materna, saúde sexual, reprodutiva e saúde da mulher, porém em um espaço de tempo menor.

Foi somente em 1983 que o Ministério da saúde implementa o Programa de Assistência Integral a Saúde da mulher- PAISM com uma proposta diferenciada de atendimento integral a saúde da mulher.

Esse programa surge rompendo com a característica centralizadora de programas anteriores e incorpora conceitos de saúde reprodutiva e sexual que se contrapōem ao controle de natalidade, principal objetivo dos programas dirigidos à saúde das mulheres (Galvão 1999).

Segundo Galvão (1999), nos anos 50 e 60, por influência dos neomaltusianos, havia uma preocupação dos governos em controlar o crescimento populacional, que era visto como um impedimento ao crescimento econômico e ameaça ao meio ambiente.

A incorporação por parte dos governos dos conceitos de saúde sexual e reprodutiva foi reforçada pela Conferência Internacional sobre População e Desenvolvimento do Cairo (ICPD), em 1994, e pela IV Conferência Mundial sobre a Mulher, em 1995, em Beijing.

Quando discute a evolução dos conceitos no Brasil, Galvão (1999) considera que não seria possível fazê-lo sem falar do Programa de Atenção Integral à Saúde da Mulher (PAISM), que representou um avanço, já que antes a preocupação com a saúde da mulher estava restrita à preocupação com a gravidez e o parto. Porém, a implantação do PAISM teve problemas, não ocorrendo de forma homogênea em todo o País.

Scavone (1999) resgata o conceito de saúde reprodutiva e sua relação com o movimento feminista, ou seja, de como o lema, da década de 60 , usado pelas feministas, "nosso corpo nos pertence", foi desembocar no de saúde reprodutiva, conceito que foi difundido e passou a ser utilizado pelos programas de governo. 
Segundo Scavone (1999), quando isso ocorreu o conceito perdeu o sentido inicial contestatório, porém não podemos negar que, certamente, representou um avanço, na medida em que seria muito pior se as mudanças ocorressem com menos freqüência. Se não houvesse mudanças, ainda năo teriamos chegado aos conceitos de direitos sexuais e reprodutivos. As experiências foram distintas entre os países do norte e do sul pois, para a autora, nos primeiros, o conceito de saúde reprodutiva representou uma mudança no sentido de fazer da maternidade uma opção, em vez de uma fatalidade biológica.

Um ponto importante colocado por Scavone (1999), refere-se à questão de que os direitos reprodutivos não podem estar descolados de uma discussão dos direitos de primeira geração, ou seja, os civis e políticos. Tanto que, no caso da América Latina, a luta pela democratizaçăo dos Estados fez parte da agenda de reivindicações do movimento feminista.

Berquó (1998) em discussão que resgata o papel do Brasil na Conferência Internacional sobre Populaçăo e Desenvolvimento, que aconteceu no Cairo em 1994, observa que ali o debate foi travado entre os que defendiam o planejamento familiar como tema central e aqueles que defendiam a discussão sobre os direitos reprodutivos.

A conferência trouxe consigo uma "estratégia" mais holística, o que significa dizer que năo foi um abandono das questões populacionais, mas um entendimento da problemática mais geral, ou seja, de que a diminuição da fecundidade está além do âmbito do planejamento familiar, e também incorpora o acesso à educaçăo e saúde, entre outros.

Atualmente, o conceito de saúde reprodutiva vem sendo, por vezes, substituído por direitos sexuais e reprodutivos, num contexto que, além de incorporar a saúde das mulheres que optaram pela maternidade, também agrega a de grupos com diferentes orientaçőes sexuais, ou mesmo a maternidade como uma opção e năo uma obrigação. A mudança de saúde da mulher para direitos reprodutivos, avança no sentido de incluir a discussão de relaçóes de gênero mais igualitárias. 
Os conceitos de direitos sexuais e reprodutivos surgiram dentro do movimento feminista e de sua relação direta com a cidadania. Assim, não podemos perder de vista o importante papel do Estado para a efetivação dos direitos gerais e específicos, ainda que seja em um contexto de globalização no qual a figura do Estado se enfraquece.

Para Ávila e Gouveia (1996), a temática dos direitos reprodutivos e sexuais está articulada com vários pontos de tensão, tais como "as relaçōes público/privado; sexualidade/ reprodução; direito como ação normativa e reguladora/liberdade; universalização/fragmentação; Estado/individuo" (163). Para as autoras, tais direitos estão diretamente relacionados com as condiçōes socioeconômicas e políticas, sendo conquista da ação das mulheres. Assim, amplia-se de tal forma o debate, que pode levar a uma mudança não somente das relaçōes de gênero, as das relaçōes sociais, mudando assim não só a vida das mulheres, mas de toda a sociedade.

\section{Morbi-mortalidade e gênero}

A maioria dos trabalhos na área da saúde pública, que consideram ou utilizam o enfoque de gênero, trazem como tema central a sexualidade e a violência contra a mulher. Trabalhos que privilegiam a variável sexo e apresentam as diferenças de morbidade entre homens e mulheres são em menor número. Dentre eles, destacamos estudo feito por Laurenti et al. (1998) que juntamente com outros autores, analisa a saúde masculina na região das Américas.

Em seu trabalho Laurenti et al. (1998) refere que quando comparada a mortalidade e morbidade por sexo, constata-se que, enquanto os indicadores de mortalidade apresentam uma sobre-mortalidade masculina, independente da idade e causa, em estudos sobre a demanda de serviços ou inquéritos domiciliares, verifica-se uma freqüência superior feminina.

O autor diz ainda que, embora difícil uma explicação para as causas dessas diferenças- pois vários fatores interferem na morbi-mortalidade- se 
por um lado as diferenças biológicas explicam em parte, por outro lado, não se pode negar que algumas das desigualdades são explicadas pelas diferenças de gênero, devido às características baseadas na construção social dos sexos.

"Assim, certos fatores comportamentais, mais do que os biológicos, favorecem ou propiciam, do ponto de vista de gênero, a maior freqüência de determinados agravos ou mesmo maior letalidade, em um sexo ou no outro" (Laurenti et al. 1998, p.2.). Este pensamento exemplifica a sobre-mortalidade masculina, no caso do câncer de pulmão ou das mortes por causas violentas, que não podem ser explicadas simplesmente como uma diferença biológica. De certo, as diferenças entre os gêneros, acabam por gerar um desequilíbrio demográfico com conseqüências econômicas e sociais principalmente para a mulher que acaba tendo que assumir encargos sozinha. (Laurenti et al. 1998)

Um recorte que consideramos importante para o estudo da morbidade é a separação de homens e mulheres por ciclos de vida, já que diferentes fatores interferem na morbi-mortalidade nas diversas fases da vida de uma pessoa. E, mesmo na infância, quando os fatores biológicos são os principais motivos do adoecer e morrer, podemos encontrar componentes sociais que contribuem para explicar as diferenças por sexo. Um exemplo, foi encontrado em trabalho feito por Gómez-Gómez (1993), que discute a discriminação por sexo e a sobre-mortalidade feminina na infância, na região das Américas e demonstra que, apesar da diferença biológica, que daria maior vantagem para as mulheres, em alguns paises da América Latina existe uma provável discriminação por sexo que contribui para uma sobremortalidade feminina na infância.

A autora partiu de duas hipóteses: a primeira supunha que as diferenças por sexo, segundo causa, fossem constantes; e a segunda, que as diferenças por causas específicas variavam de acordo com o contexto geográfico e sócio-econômico. Essa segunda hipótese baseava-se no argumento de que a discriminação sexual era resultado de uma pior nutrição 
e atençăo dada às crianças do sexo feminino, propiciando conseqüentemente, que estas estariam mais susceptiveis a mortes por doenças infecciosas.

Como conseqüência das condições sócio-demográficas, apresenta quatro fases da relação entre mortalidade por sexo:

1) Na primeira fase, que se caracteriza por uma alta mortalidade geral e um baixo desenvolvimento económico, encontra-se uma alta mortalidade feminina, principalmente durante a idade reprodutiva;

2) $\mathrm{Na}$ segunda, denominada de "mortalidade intermediária", a mortalidade masculina começa a superar a feminina nos diferentes ciclos de vida;

3) $\mathrm{Na}$ terceira, caracteristica dos paises desenvolvidos, ocorre um declínio da mortalidade feminina e uma estabilização da masculina;

4) A última fase, denominada de "pós-transicional", caracteriza-se pela reduçăo da mortalidade masculina na infância (neonatal e fetal), como resultado dos avanços tecnológicos no combate às causas.

Como fontes, além dos dados de mortalidade da OPAS, Gómez Gómez utilizou as Enquetes Demográficas e de Saúde sob coordenaçăo do Institute for Resource Development (IRD) e trabalhos realizados pelo Centro Latino Americano de Demografia (CELAD) sobre mortalidades por causa. Após analisar os dados dessas diferentes fontes, considerou a sobremortalidade de crianças do sexo feminino como um alarme para a discriminação das mesmas na infância, em alguns países da América Latina.

Quanto à saúde mental, encontramos o texto de Emslie et al. (2002), no qual é feito um estudo comparativo da morbidade psiquiátrica de menor 
gravidade entre homens e mulheres "White-collar" em três tipos de organizaçōes: banco, universidade e funcionários públicos. Concluiram que, apesar de diversos estudos indicarem maior tendência das mulheres reportarem doenças psiquiátricas de menor gravidade, as diferenças entre homens e mulheres podem variar segundo o contexto de estudo. A carga horária e o tipo de trabalho, bem como a função dentro de uma empresa, são elementos que podem interferir no resultado de uma pesquisa. No caso da investigação que realizaram, não encontraram grandes diferenças entre homens e mulheres que trabalhavam em banco e universidade e ocupavam o mesmo cargo. As diferenças significativas apareceram somente no caso dos funcionários públicos.

Dunnell et al. (1999) apresentam um trabalho com o objetivo de descrever os principais bancos de dados nacionais de saúde existentes na Inglaterra, e como eles podem ser utilizados para se estudar as diferenças na saúde por gênero.

Os autores apresentam, nesse trabalho, as principais fontes de dados coletados e trabalhados rotineiramente pelo governo britânico: $O$ “Mortality Statistics", que resulta do registro nacional de mortes, criado em 1837 , dispõe de dados com os quais se calcula a expectativa de vida, taxa de mortalidade padronizada e mortalidade infantil; o "Cancer Statistics", é o registro de câncer que pode ser utilizado para o cálculo de prevalência e incidência, taxa de sobrevida e taxa de mortalidade; o "General Practice Research Database (GPRD)", que oferece dados sobre os serviços de saúde, com que se pode calcular indicadores de prevalência e incidência de diversas doenças; o "Longitudinal Study", que a partir de uma amostra de $1 \%$ da população, oferece dados utilizados para o estudo das tendências de distribuição da mortalidade por sexo e classe social.

Além das fontes citadas, os autores ainda apresentam os principais surveys: O "General Household Survey (GHS), "Health Surveys for England", - OPCS Survey of Psychiatric Morbidity, "National Survey of Morbidity" e "Dental Health Surveys. 
Para cada uma das fontes citadas, os autores fazem comentários sobre as potencialidades do uso de indicadores por sexo, que contribuem para o debate sobre a natureza das diferenças entre homens e mulheres em mortalidade, morbidade e acesso a serviços. Concluem que essas pesquisas devem ser mais utilizadas para se entender as razões das diferenças e similaridades, na área da saúde, entre homens e mulheres. Esses autores observaram nas estatísticas oficiais de mortalidade, que as mulheres tem taxas inferiores aos homens em todas as idades e na maioria das causas de morte o que reflete em uma maior expectativa de vida para as mulheres.

Para morbidade, analisaram a pesquisa domiciliar GHS de morbidade auto-referida. Nela os entrevistados respondem sobre doenças crônicas, se existia limitação em função da enfermidade referida e se tiveram suas atividades rotineiras restritas nas duas semanas anteriores à pesquisa, devido a alguma doença aguda. Os autores reconhecem que esse tipo de pesquisa tem como limitaçăo as diferenças individuais na percepção do estado de saúde.

Em relação às doenças crônicas e às limitaçőes em decorrência das mesmas, observaram que ocorre um incremento na referência para homens e mulheres com o aumento da idade, sendo que a partir dos 65 anos a porcentagem de mulheres é superior a de homens. Quanto às limitaçð̃es nas duas semanas anteriores à pesquisa, a porcentagem de mulheres foi um pouco superior aos homens, ocorrendo também um incremento com 0 aumento da idade.

Quanto aos fatores de risco para doenças do coração e infarto, os autores analisaram informações da "Health Survey for England", que coleta dados sobre o índice de massa corporal (body mass index-BMI), colesterol e pressão sangüínea. Com o aumento da idade, os três indicadores apresentaram um incremento até os 75 anos. Após esta idade o índice de massa corporal e do colesterol diminuem. As mulheres até os 55 anos apresentaram números inferiores do indice de massa corporal, colesterol e pressão sanguínea, comparado com os homens. Após essa idade a 
prevalência feminina passa a ser superior à masculina para a pressão sangüínea e colesterol.

Para a análise das doenças psiquiátricas, Dunnell et al. (1999) utilizaram a OPCS. Verificaram que, para todas as idades, as mulheres apresentaram maior prevalência de distúrbios neuróticos; porém, a proporçăo diminui quando considerados os demais transtornos mentais, sendo que aqueles provocados por dependência ao álcool e drogas foram mais comuns entre os homens para todas as faixas etárias.

A utilizaçăo dos serviços também foi analisada pelos autores, que usaram como fonte a GHS. Ambos os sexos, para os casos mais graves, apresentaram quase as mesmas taxas de consulta ambulatoriais, nos casos de menor gravidade ou intermediária, as mulheres apresentaram taxas muito maiores comparada com os homens, porém essas diferenças diminuem a partir dos 70 anos.

As taxas masculinas de utilizaçăo de serviços hospitalares foram superiores às femininas, exceto para o grupo de 16 a 44 anos, idade reprodutiva.

Quanto à prescrição de medicamentos, no ano de 1995, usando como fonte o Health Survey for England, constataram que as taxas femininas, com um pequeno diferencial, foram superiores às masculinas, porém observaram um aumento na diferença na faixa etária de 45 a 64 anos, provavelmente, segundo os autores, devido à reposição hormonal.

Para Dunnell et al. (1999), apesar dos homens morrerem mais, principalmente, na faixa de adultos jovens, isto não significa que as mulheres sejam mais saudáveis. Na verdade, elas adoecem mais, ou, pelo menos, procuram mais o médico, já que têm as maiores taxas de consulta por pequenos problemas. Essa particularidade de homens e mulheres também aparece em outros trabalhos (Aquino et al. 1992; Pinheiro et al. 2002).

Pinheiro et al. (2002) relatam que, em trabalhos internacionais, enquanto os homens padecem de enfermidades crônicas fatais, as mulheres referem doenças de curta duraçăo e agudas, de baixa letalidade. Essas 
diferenças, por um lado são fruto de aspectos genéticos ou hormonais; por outro, ocorrem porque nas sociedades modernas as estruturas de gênero determinam a divisão do trabalho, o poder, as práticas sexuais e diferenças de identidades que refletem comportamentos e riscos distintos (Connell 2000).

Nivel socioeconômico e etnia săo elementos que interferem igualmente na morbidade auto-referida de homens e mulheres. Cooper (2002), usando com fonte o Health Survey for England no periodo de 19931996, constatou que a baixa morbidade de adultos brancos contrasta com a alta, referida por mulheres de minorias étnicas, comparadas com homens do mesmo grupo.

A alta morbidade de adultos de grupos étnicos em piores condições socioeconômicas aparece na análise de regressão feita pelo autor, que também constatou que as desvantagens são maiores ainda para as mulheres desses grupos. No Brasil, estudo comparativo da morbidade autoreferida foi realizado por Pinheiro et al. (2002), que analisaram, ainda, o acesso e uso de serviços para homens e mulheres, baseado na Pesquisa de Amostra Domiciliar 1998 (PNAD-98). Com este trabalho, averiguaram que tanto na zona rural, quanto na urbana, existem diferenças desvantajosas para as mulheres na morbidade auto-referida. Os problemas crônicos afetam tanto um sexo quanto o outro, mas a prevalência é superior para as mulheres, em todas as doenças que selecionaram. Na pesquisa, $23,5 \%$ das mulheres e $18,2 \%$ dos homens, relataram estado de saúde deficiente.

Segundo os autores, a percepção de saúde é fator de interferência em pesquisas de morbidade auto-referida, pois esta "pode variar em funçăo de fatores ligados às experiências sociais dos indivíduos e à disponibilidade de serviços de saúde, o que não foi considerado no trabalho" (Pinheiros et al. 2002, p.703). Para Rea e colaboradores (2000, p.144) "a percepção da alteração da saúde como doença é um fenômeno cultural e mutante".

As mulheres relataram com mais freqüência uso regular de serviços de saúde, consultas médicas e serviços odontológicos. Enquanto procuram 
mais os serviços para exames de rotina ou cuidados preventivos, os homens buscam os serviços para cuidados curativos (Pinheiro et al. 2002).

Os serviços mais procurado por homens e mulheres foram o posto ou centros de saúde, consultório particular e hospital. Enquanto nos dois primeiros a proporção feminina é um pouco superior à masculina, no caso do hospital a ordem se inverte, com uma pequena diferença. Quanto aos tipos de serviços procurados, as mulheres procuram mais os ambulatórios especializados, e os homens o Pronto-Socorro, farmácia e ambulatório do sindicato.

Pelos trabalhos apresentados pode-se concluir que os homens morrem mais, porém as mulheres adoecem mais ou pelos menos, são elas que procuram mais os serviços, principalmente preventivos. Como à mulher cabe o cuidado dos filhos, isso faz com que ela freqüente mais os serviços preventivos. Para os homens, o acesso é dificultado pelo horário de funcionamento, porque este geralmente entra em choque com o horário de trabalho.

As diferenças no perfil de morbi-mortalidade não podem ser explicadas apenas por aspectos biológicos inerentes aos dois sexos, porém também interferem os aspectos culturais e socioeconômicos. 


\section{Capitulo III Metodologia}

\section{Construindo o percurso de trabalho a AlH}

Na sociedade contemporânea, a informação representa um elemento estratégico de controle do Estado sobre a população. Além dessa característica, ela também tem papel de destaque na vida das pessoas. Em sociedades "destradicionalizadas" a conduta dos indivíduos já não se baseia em tradições, mas na imensa gama de informações, técnicas ou não, que são recebidas a todo momento. Esse processo foi denominado por Giddens (1996) de reflexividade, e contribui para uma democratização das relações tanto no plano individual, quanto coletivo. Nesse contexto a informação proporciona uma relação mais transparente entre o Estado e a sociedade.

Em uma sociedade reflexiva, com incertezas artificiais, o acesso de indivíduos ou grupos à informaçăo em geral, e especificamente em saúde, torna-se elemento importante na redução do risco. A informação tem um sentido político. Enquanto um banco de dados é um conjunto de símbolos, a informação traz consigo o significado; e ela que garante que o dado se torne compreensível. É dentro dessa lógica que se coloca o nosso objeto de estudo.

Tomando como fonte de dados 0 arquivo $\mathrm{AlH}$, que pertence ao Sistema de Informação Hospitalar do SUS (SIH/SUS), buscamos analisar a morbidade hospitalar, usando a variável sexo como um indicativo da categoria gênero e o IDH como um indicador socioeconômico, pois ser um conceito transversal. $\mathrm{O}$ banco de $\mathrm{AlH}$ é a fonte de dados mais regular e universal de morbidade no País (Mendes et al. 2000).

Nosso universo foram as internaçōes do SUS, por local de residência no ano de 2002, de seis regiőes metropolitanas: Núcleo da RM do Norte/Nordeste de Santa Catarina, RM de Campinas, RM de Porto Alegre, a RM de São Luis, RM de Maceió e o Colar Metropolitano do Vale do Aço. 
$\mathrm{Na}$ proposta inicial pretendiamos trabalhar com todo o universo de internaçőes do SUS no Brasil no ano de 2000; porém; após uma primeira aproximaçăo com o banco de dados e influenciada pelas leituras, optamos por alterar nossa proposta inicial. Nossa primeira alteração foi em relação ao periodo, pois de acordo com alguns textos, quanto mais recente melhor a qualidade do dado no banco da AlH. Portanto optamos por utilizar o ano mais recente disponivel em CD ROM, que foi 2002.

Uma outra opção foi um recorte da população no período reprodutivo de 15 a 49 anos. Essa escolha está embasada tanto nas leituras que discutiam a morbi-mortalidade, quanto naquelas sobre o conceito de gênero. Biologicamente a vida reprodutiva masculina é mais longa que a feminina. Porém, para compararmos populaçōes com características semelhantes, optamos por fazer o mesmo recorte etário para homens e mulheres.

Para esse recorte, o texto de Barbieri (1991) foi nossa principal referência, pois segundo a autora, a idéia de uma diversidade dentro da identidade masculina e feminina relaciona-se com o ciclo de vida, que também é uma construção social. Para Barbiere, a principal etapa é aquela em que homens e mulheres estão em sua plena capacidade de reproduçăo, quando, segundo a autora, pode-se observar os elementos chaves das relações que prevalecem no sistema de gêneros de uma dada sociedade.

$\mathrm{Na}$ literatura sobre morbidade, acesso a serviços de saúde e gênero encontramos alguns trabalhos relatando que, entre homens e mulheres de uma mesma etnia e grupos econômicos, nāo foram encontradas diferenças significativas entre os gêneros. Segundo esses trabalhos, são as mulheres de minorias étnicas e grupos menos favorecidos economicamente que aparecem em condiçőes desfavoráveis.

Entre as limitações do banco de dados utilizado está a falta de dados socioeconómicos e sobre etnia do paciente. Diante da questâo colocada pela bibliografia, começamos a pensar em uma maneira de agregar aspectos socioeconômicos em nossa análise. Foi quando, após alguns 
levantamentos, identificamos o Indice de Desenvolvimento Humano-IDH como uma alternativa.

Para a seleção das Regiōes Metropolitanas, utilizamos o Indice de Desenvolvimento Humano (IDH-RM) no ano de 2000, este recorte foi pensado para tentar suprir a falta de variáveis sócio-económicas no banco do SIH. Escolhemos regiōes com os mais altos valores e baixos IDH, expurgando aquelas que estivessem nas mesmas regiozes. Foram selecionadas a RM do Norte/Nordeste de Santa Catarina-Núcleo, RM de Porto Alegre e RM de Campinas, e com baixo IDH foram escolhidas o Colar Metropolitano do Vale do Aço, região com o menor IDH, a RM de São Luis, por representar a pré-amazônia e a RM de Maceió, representante da região do nordeste oriental.

Resolvidos esses obstáculos, nos voltamo-nos para o banco de dados buscando responder a seguinte questão: Existem diferenças na morbidade hospitalar para homens e mulheres em regiões metropolitanas com diferentes IDHs?

No arquivo reduzido de $\mathrm{AlH}$ existem 62 tipos de registro diferentes (Anexo 1), que incluem dados sobre a caracterização do hospital, sexo, local de residência, atendimento e código da idade do paciente, diagnóstico, procedimentos realizados, tempo de permanência e 0 valor pago pelo atendimento. Partindo desses registros selecionamos as seguintes variáveis: idade, sexo, local de internaçăo, local de residência, diagnóstico principal, tipo de AlH, diagnóstico secundário (no caso das causas externas) e óbito.

Na seleçăo das variáveis e os cruzamentos utilizamos o Excel e o Tabwin32, programa disponibilizado pelos DATASUS juntamente com 0 CD ROM.

Para comparaçăo das taxas de internação por diagnóstico e sexo para cada uma das regióes utilizamos o Teste de proporçăo para duas amostras. Tínhamos como hipótese 0 que $p 1=p 2$ versus $H 1: p 1 \neq p 2$, onde $p$ é a proporçăo de um dado grupo. Se o valor $p$ encontrado ao nível de significância $a \leq 0,05(5 \%)$ concluímos que existe diferença. Esse teste foi 
aplicado para verificar se as diferenças observadas, entre homens e mulheres, eram estatisticamente significantes.

Apesar de reconhecemos a importância das causas relacionadas à saúde reprodutiva feminina, optamos por retirar desse trabalho o capítulo $\mathrm{XV}$ referente à gravidez e parto, pois consideramos que esse tema já foi trabalho em outros estudos sobre a saúde reprodutiva e diferenças de gênero.

\section{Regiōes metropolitanas}

Regiōes Metropolitanas (RMs) são áreas que, devido ao crescimento das cidades, formaram grandes áreas urbanas conurbadas, com comunicação econômico-social e problemas comuns. Nessas regiōes, existe um fluxo de pessoas, bens e serviços que acabam por demandar uma infraestrutura que ultrapassa as fronteiras municipais, gerando a necessidade de um novo centro administrativo.

Segundo Guimarães (2004), essas regiōes quase sempre se formam ao redor de um município com intensa atividade econômica e social, que o torna pólo de atração e desencadeia um desenvolvimento regional, já que existe um fluxo entre esse e os demais. No final de 2003, no Brasil, eram computadas 26 unidades metropolitanas, que foram implantadas em dois momentos distintos.

As primeiras RMs foram criadas na década de 70, dentro de uma política nacional de desenvolvimento e organização urbana. Nesse periodo a definição era de responsabilidade do Governo Federal e tinha como lógica agrupar municípios com características socioeconômicas semelhantes, visando a "realização de serviços comuns ${ }^{5 n}$. A gestão ficaria a cargo de dois Conselhos, um Deliberativo e um Consultivo. O primeiro, com poder

\footnotetext{
5 - Segundo a Lei Complementar 14/73: I - planejamento integrado do desenvolvimento económico e social; II saneamento basico, notadamente abastecimento de agua e rede de esgotos e serviços de limpeza pública; III uso do solo metropolitano; IV - transportes e sistema viário; V - produçáo e distribuiça do gás combustivel canalizado; VI - aproveitamento dos recursos hidricos e controle da poluiçao ambiental, na forma do que dispuser a lei federal; VII - outros servicos inciuidos na area de competencia do Conselho Deliberativo por lei federal" (Moura et al. 2004, p.2)
} 
deliberativo, composto de membros designados pelo poder executivo estadual, e o segundo composto pelos prefeitos ou seus representantes, com caráter consultivo (Moura et al. 2004; Guimarães 2004).

Com a Constituição de 1988, dentro de uma proposta de descentralização, a responsabilidade de criação passou para o governo dos estados, que deveriam obedecer à mesma lógica de organização. Além da possibilidade de implantação de novas RMs, áreas de expansão e modificação das existentes, essa nova regra permitia aos estados a criação de outras formas de organização como as aglomeraçōes urbanas $e$ as microrregiões (Moura et al. 2004; Guimarães 2004).

Essa nova forma de implantação de RMS, considerada menos autoritária que a anterior, permite a participação dos três niveis de governos, Uniăo, Estado e município, cada qual com sua responsabilidade. $\mathrm{Na}$ Constituição ficaram definidos, como objetivos da organização regional, a "integraçăo, a organizaçăo, o planejamento e a execuçăo de funçōes públicas de interesse comum" (Hotz 2000, p.93).

Para Moura et al. (2004), essa descentralização criou "unidades regionais bastante distintas e, até certo ponto, incomparáveis", devido à inexistência de projetos estaduais de regionalizaçăo e da falta de regras na Constituição Federal que defina a criação das mesmas. Essa característica, apontada como desvantagens, para nós foi o principal motivo de escolha, por oferecer possibilidades de observar regióes com características distintas.

Quanto à criaçăo das RMs selecionadas, as de Porto Alegre e Săo Luis foram implantadas em 1973 (EMPLASA 2004), dentro da política nacional de desenvolvimento do Governo Federal. Porém, após a Constituição de 1988, sofreram alterações. De criação mais recentes, em 1998, são as RMs de Maceió, Colar Metropolitano do Vale do Aço e N/NE de Santa Catarina. A RM de Campinas foi criada somente no ano de 2000. (Anexo 2) 
O Indice de Desenvolvimento Humano (IDH), atualmente sob responsabilidade do Programa das Nações Unidas para o Desenvolvimento (PNUD), foi criado pelo economista paquistanês Mahbub ul Haq em colaboraçăo com o economista indiano Amartya Sen. Com esse índice visase superar a limitaçăo do Produto Interno Bruto (PIB) per capita, indicador que considera apenas os aspectos económicos na avaliação da qualidade de vida das populações (UNESCO/ PNUD 2003).

O IDH representa uma medida sintese de diversos aspectos, educaçăo (alfabetizaçăo e taxa de matricula), longevidade (esperança de vida ao nascer) e renda (PIB per capita). Seu valor varia de 0 , em caso de nenhum desenvolvimento humano, a 1, o valor máximo (UNESCO/ PNUD 2003).

Países com valor inferior a 0,499 têm desenvolvimento humano considerado baixo, entre 0,500 e 0,799 săo considerados de médio desenvolvimento humano; e se superior a 0,800 , têm desenvolvimento humano considerado alto (UNESCO/ PNUD 2003). Este índice, idealizado inicialmente para paises, foi adaptado para municípios (IDH-M) e Regióes metropolitanas (IDH-RM). E apesar de utilizar os mesmos aspectos, difere dos indicadores utilizados para medir as condiçōes sociais (UNESCO/ PNUD 2003).

No cálculo do IDH-M e do IDH-RM, para medir a dimensão educação (IDH-E), foram utilizadas a taxa de alfabetização de pessoas acima de 15 anos de idade (com peso dois) e a taxa bruta de frequeência à escola (com peso um). Para medir $O$ aspecto longevidade (IDH-L) foi utilizada a esperança de vida ao nascer. Porém, devido à subnotificaçăo existente, emprega-se uma estimativa da mortalidade. A medida da dimensăo renda (IDH-R) foi dada pela renda per capitã, por residente da região ou município. O IDH-M ou IDH-RM é a média aritmética simples dos três sub-índices (UNESCO/ PNUD 2003). 
Os dados utilizados para o cálculo do IDH foram os questionários detalhados, aplicados em uma amostra pelo censo do IBGE e ampliados para o total da população (Anexo 3).

Tabela 3 : IDHM91 e IDHM00 para as Regiōes Metropolitanas selecionadas.

\begin{tabular}{|l|c|c|c|c|c|c|}
\hline Regiăo Metropolitana & IDHM_91 & $\begin{array}{l}\text { Rank } \\
91\end{array}$ & IDHM_00 & $\begin{array}{l}\text { Rank } \\
00\end{array}$ & $\begin{array}{l}\text { Crés. } \\
\text { Relativo }\end{array}$ & Posiçб̌es \\
\hline $\begin{array}{l}\text { Núcleo Metropolitano da } \\
\text { RM Norte/Nordeste } \\
\text { Catarinense }\end{array}$ & 0,776 & 7 & 0,853 & 2 & $9,9 \%$ & 5 \\
\hline RM de Campinas & 0,788 & 4 & 0,835 & 4 & $6,0 \%$ & 0 \\
\hline RM de Porto Alegre & 0,782 & 5 & 0,833 & 6 & $6,6 \%$ & -1 \\
\hline RM da Grande Såo Luís & 0,707 & 29 & 0,766 & 30 & $8,4 \%$ & -1 \\
\hline RM de Maceió & 0,660 & 32 & 0,724 & 32 & $9,7 \%$ & 0 \\
\hline $\begin{array}{l}\text { Colar Metropolitano da } \\
\text { RM Vale do Aço }\end{array}$ & 0,601 & 33 & 0,687 & 33 & $14,3 \%$ & 0 \\
\hline
\end{tabular}

Fonte: PNUD.2002

A RM do Colar Metropolitano do Vale do Aço tem o menor valor de IDH encontrado nas RMs (Anexo 4), 0,687, conforme quadro anterior. Reconhecemos, porém, que esse valor não representa a área de maior pobreza no País. Pelo contrário, por se caracterizar como metropolitana, algum desenvolvimento económico e recurso existem no local, e, em relação à realidade do País, com certeza existem áreas mais miseráveis. 


\section{Capitulo IV Perfil das Regiões Metropolitanas}

\section{Perfil Sócio-demográfico das Regiões Metropolitanas}

As Regióes metropolitanas selecionadas para este estudo representam realidades distintas. Neste capítulo traçamos um perfil sóciodemográfico, identificando semelhanças e diferenças, visando uma caracterização das mesmas.

Em relaçăo ao tamanho populacional das RMs e sua participaçăo na população nacional, as regiões diferem bastante. Porto Alegre é a maior delas, seguida pela RM de Campinas, sendo as RMs do N/NE de Sta Catarina e do Colar Metropolitano do Vale do Aço as de menor participação.

Na RM do N/NE de Sta Catarina foi onde encontramos a maior concentração populacional no pólo. A Região é composta por apenas dois municípios. Por outro lado, na RM do Colar Metropolitano do Vale do Aço, a população está dispersa pela região, pois além de ser a RM com menor população, se distribui por 22 municípios, enquanto que no município considerado o pólo concentram-se apenas $11 \%$ da mesma.

Tabela 4: Participação da RM na populaçăo brasileira, participação da população do pólo na RM, população da RM, municípios sede e total de municípios. Regiōes Metropolitanas, 2002.

\begin{tabular}{|c|c|c|c|c|c|}
\hline $\begin{array}{l}\text { Regiko } \\
\text { Motropolitana }\end{array}$ & $\begin{array}{l}\text { Participaçăo } \\
\text { na populaçăo } \\
\text { do Brasil }\end{array}$ & $\begin{array}{l}\text { Part. Pop. } \\
\text { Pólo/RM }\end{array}$ & Populaçăo & $\begin{array}{l}\text { Municipio } \\
\text { sede }\end{array}$ & $\begin{array}{l}\text { Total de } \\
\text { municipios }\end{array}$ \\
\hline Núcleo do $\mathrm{N} / \mathrm{Ne}$ & & & & & \\
\hline $\begin{array}{l}\text { de Santa } \\
\text { Catarina }\end{array}$ & 0,27 & 94,78 & 471689 & Joinvile & 2 \\
\hline $\begin{array}{l}\text { RM de } \\
\text { Campinas }\end{array}$ & 1,38 & 41,46 & 2437484 & Campinas & 19 \\
\hline $\begin{array}{l}\text { RM de Porto } \\
\text { Alegre }\end{array}$ & 2,19 & 36,59 & 3827272 & $\begin{array}{l}\text { Porto } \\
\text { Alegre }\end{array}$ & 31 \\
\hline $\begin{array}{l}\text { RM da Grande } \\
\text { São Luis }\end{array}$ & 0,63 & 81,26 & 1123407 & São Luis & 4 \\
\hline RM de Maceió & 0,58 & 80,65 & 1031803 & Maceio & 11 \\
\hline $\begin{array}{l}\text { CM da RM do } \\
\text { vale do Aço }\end{array}$ & 0,10 & 11,94 & 164283 & Ipatinga* & 22 \\
\hline
\end{tabular}


A proporção da população do grupo etário de 15 a 49 anos foi distinto, nas RMs selecionadas, variando de 51,1\%, - a menor proporção encontrada na RM do Vale do Aço-Colar - a 58,4\% na RM do N/NE de Sta CatarinaNúcleo. (Gráfico 1)

Gráfico1: Proporção da população de 15 a 49 anos, segundo Regiões Metropolitanas. 2002.

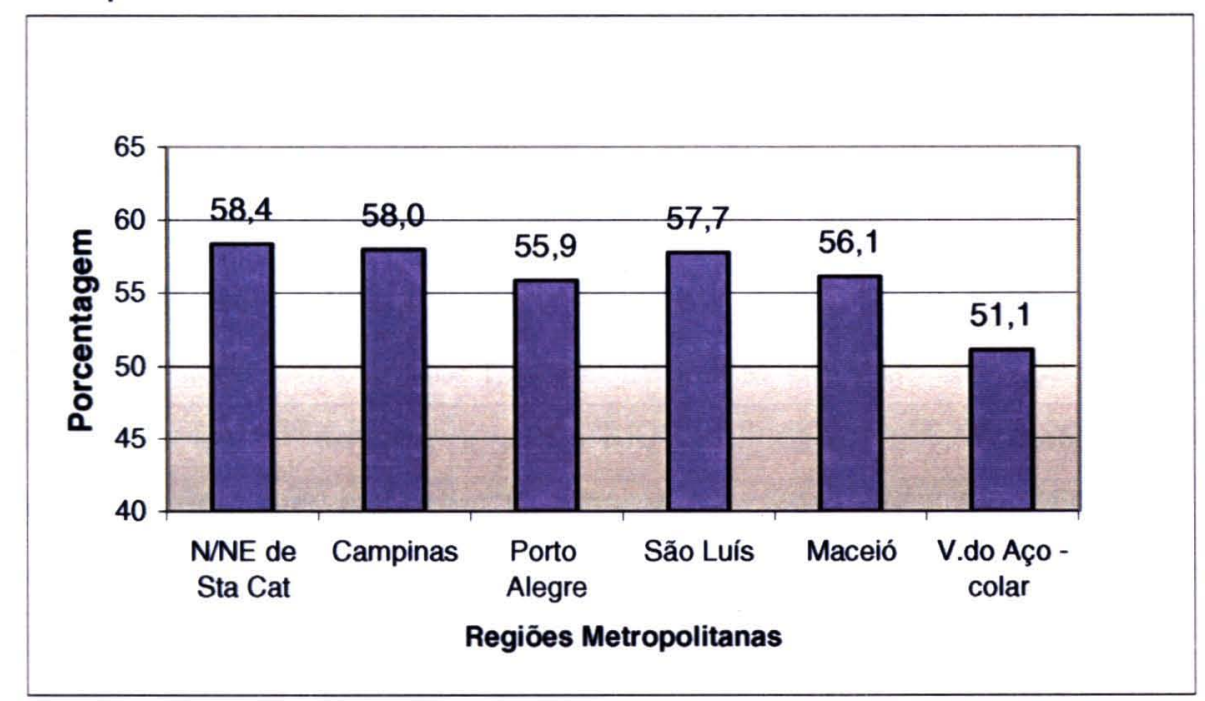

Fonte:IBGE- www.datasus.gov.br [7/2004]

Distinta também foi a distribuição por sexo: a maior diferença entre a proporção masculina e a feminina está na RM de São Luis, seguida pela RM de Maceió, conforme podemos observar no gráfico 2, apresentado a seguir:

Gráfico 2: da proporção por sexo na população de 15 a 49 anos. Regiões Metropolitanas, 2002.

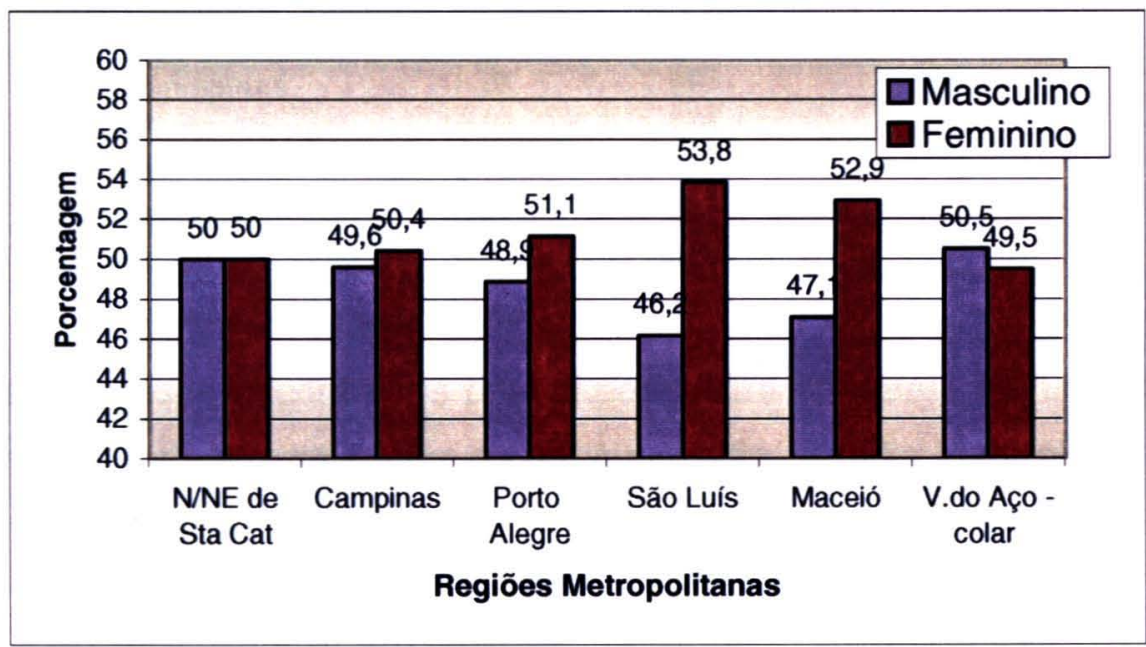

Fonte:IBGE- www.datasus.gov.br [7/2004] 
A seguir, apresentamos os indicadores demográficos para as regiōes metropolitanas.

\section{Perfil Demográfico}

A fecundidade e mortalidade são fenômenos demográficos que vão interferir no crescimento ou não de uma população. Por outro lado, sofrem influência da estrutura por sexo e idade da mesma. Esses dois fatores, juntamente com a migraçăo, são os elementos que compõem a dinâmica populacional.

\section{Estrutura por sexo}

A razão de masculinidade permite medir o equilibrio entre os sexos em uma determinada população. Exceto pela RM do Vale do Aço, na qual esse indicador foi de 1014 homens para 1000 mulheres, nas demais regióes, a população feminina é superior à masculina. Nas RMs de São Luis e Maceió, encontramos o maior desequilibrio entre os dois sexos, 892 homens para mil mulheres e 909 , respectivamente.

Apesar dessas diferenças para a população em geral, em todas as RMs os nascimentos masculinos foram superiores aos femininos, pois em todas elas podemos observar, conforme quadro 5 , razão de masculinidade superior a 1000 para o grupo etário menores de um ano.

Tabela 5:Razăo de masculinidade para populaçăo total, menores de 1 ano e populaçăo de 15 a 49 anos. Regiōes Metropolitanas, 2002.

\begin{tabular}{lccc}
\hline $\begin{array}{l}\text { Região } \\
\text { Metropolitana }\end{array}$ & Menor 1 ano & 15 a 49 & $\begin{array}{c}\text { Total da } \\
\text { populaçå }\end{array}$ \\
\hline N/NE de Sta Catarina & 1024 & 999 & 990 \\
RM de Campinas & 1039 & 984 & 978 \\
RM de Porto Alegre & 1045 & 955 & 936 \\
RM de Sáo Luiz & 1041 & 857 & 892 \\
RM de Maceió & 1018 & 889 & 909 \\
RM do V do Aço-Colar & 1066 & 1021 & 1014 \\
\hline
\end{tabular}

Fonte:IBGE- unw. datasus.gov.br [7/2004]

Os resultados encontrados para a população em geral, podem sofrer variações, dependendo do grupo etário. Na região de São Luis, na qual a 
proporção foi de 892 homens para mil mulheres, o valor desse indicador cai para 843 na faixa etária de 25 a 29 anos e 836, no grupo etário seguinte.

Gráfico3: Razão de masculinidade por grupo etário. Regiões Metropolitanas, 2002.

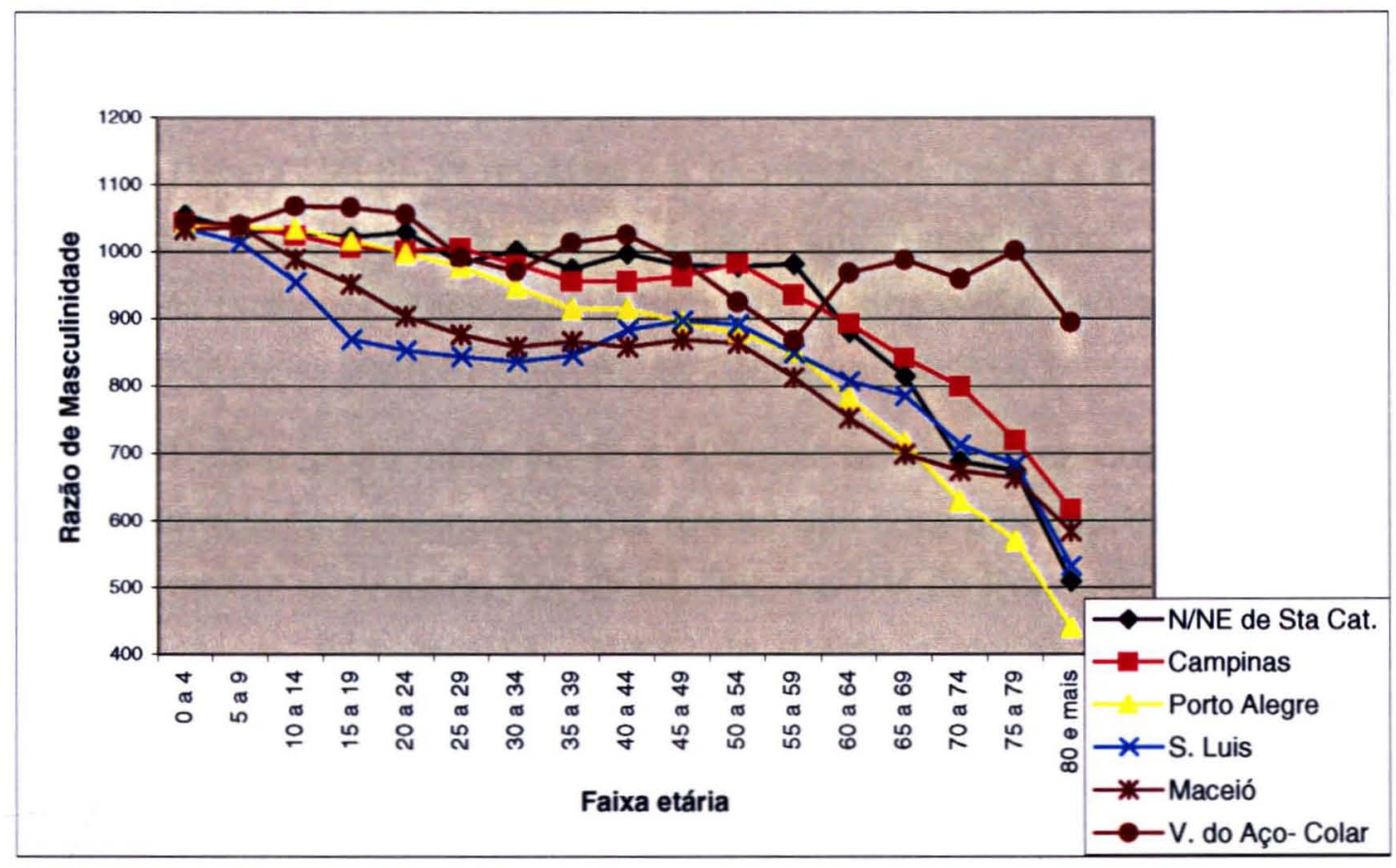

Fonte:IBGE- www.datasus.gov.br [7/2004]

$\mathrm{Na}$ RM de Maceió a partir da faixa etária de 10 a 14 anos se encontra uma maior proporção de mulheres (988 homens para mil mulheres). Essa relação permanece desigual para as demais faixas etárias.

$\mathrm{Na}$ RM do Vale do Aço a proporção se inverte: para cada mil mulheres existem 1014 homens. Porém, essa relação não se mantém quando observamos por faixa etária: até o grupo de 20 a 24 anos, o número de homens é superior; nos grupos de 25 a 29 e 30 a 34, diminui ficando em 991 e 971 , respectivamente. Subindo novamente nas faixas etárias de 35 a 39 anos (1013/ 1000 mulheres) e de 40 a 44 (1025/1000 mulheres), nos grupos seguintes o número de mulheres passa a ser superior ao de homens.

Na RM do N/NE de Santa Catarina, até a faixa etária de 20 a 24 anos o número de homens é superior ao de mulheres, variando entre 1054, para o grupo de 0 a 4, até 1021 no grupo de 15 a 19, caindo para 983 no grupo de 
20 a 24. Esse valor sobe para 1002 entre as idades de 30 a 34, caindo para 973 no grupo seguinte.

Na RM de Campinas a proporção de homens é superior à de mulheres até a faixa etária de 25 a 29 anos, quando fica em 1005. Em seguida esse valor cai para 982 homens para mil mulheres, mantendo a maior proporção de mulheres para as demais faixas etárias.

Para a RM de Porto Alegre a proporção de homens é superior a de mulheres, até a faixa etária de 15 a 19, quando encontramos 1015 homens para mil mulheres. Após essa faixa etária, a proporção se inverte, ficando em 997 homens por mil mulheres, na faixa etária de 20 a 24.

Para o grupo etário de 15 a 49 anos, os valores encontrados foram: 857 homens para mil mulheres na RM de São Luis; 889, na RM de Maceió; 1021, na RM do Vale do Aço-Colar; 955, na RM de Porto Alegre; 984, em Campinas e 999, na RM N/NE de Santa Catarina. Estes valores, complementados pelos valores encontrados por faixa etária, indicam que talvez as diferenças possam ser explicadas por algumas regiōes representarem pólos de atraçăo para a população masculina. Dessa forma, as regiōes de Maceió e São Luis estariam expulsando, enquanto que a RM do Vale do Aço- Colar, Campinas, Santa Catarina e Porto Alegre atraem homens jovens em determinadas faixas etárias. A sobre-mortalidade masculina ou feminina, em determinadas regiőes e grupos etários, também alteram essa relação.

\section{Estrutura por idade}

De acordo com dados apresentados no Anuário de Saúde de 2002, as Regiōes Metropolitanas do Vale do Aço-Colar e de Porto Alegre săo as que apresentam o maior Indice de Envelhecimento da população, sendo 24,6\% e $24,3 \%$, para cada 100 indivíduos menores de 15 anos de idade, seguidas pelas RMs de Campinas $(22,8 \%)$, do N/Ne de Santa Catarina $(15,2 \%)$, de Maceió $(14,1 \%)$ e de Săo Luis $(11,9 \%)$. O fenómeno de envelhecimento de uma populaçăo, segundo Berquó (1980) ocorre mais em virtude da redução da fecundidade do que pela queda na mortalidade, que representaria um 
aumento da população em todas as faixas etárias, mas principalmente no grupo infantil.

Tabela 6: Razăo de dependéncia e porcentagem da população de 15 a 49 anos. Regiões Metropolitanas- 2002.

\begin{tabular}{|c|c|c|c|c|}
\hline $\begin{array}{l}\text { Regiảo } \\
\text { Metropolitana }\end{array}$ & $\begin{array}{l}\text { Razảo de } \\
\text { dependéncia }\end{array}$ & $\begin{array}{l}\text { Razảo de } \\
\text { dependência } \\
\text { Jovem }\end{array}$ & $\begin{array}{l}\text { Razáo de } \\
\text { dependência } \\
\text { de idosos }\end{array}$ & $\begin{array}{l}\text { \% da } \\
\text { Populaçăo } \\
\text { de } 15 \text { a } 50 \\
\text { anos }\end{array}$ \\
\hline $\begin{array}{l}\text { RM do N/NE de } \\
\text { Sta Catarina- } \\
\text { Núcleo }\end{array}$ & 48 & 43 & 6,6 & 58 \\
\hline $\begin{array}{ll}\text { RM de } & \text { de } \\
\text { Campinas } & \end{array}$ & 45,8 & 37,3 & 8,5 & 58 \\
\hline $\begin{array}{l}\text { RM de Porto } \\
\text { Alegre }\end{array}$ & 50 & 40,7 & 9,8 & 56 \\
\hline $\begin{array}{l}\text { RM de São Luis } \\
\text { RM de Maceió }\end{array}$ & $\begin{array}{l}54 \\
55\end{array}$ & $\begin{array}{l}48,3 \\
48,2\end{array}$ & $\begin{array}{l}5,8 \\
6,8\end{array}$ & $\begin{array}{l}58 \\
56\end{array}$ \\
\hline $\begin{array}{l}\text { RM do Vale do } \\
\text { Aço-Colar }\end{array}$ & 62 & 52,5 & 12,9 & 51 \\
\hline
\end{tabular}

Fonte: Calculado com dados da populaçăo residente retirado do site do DATASUS

Conforme se observa na tabela 6, a RM do Colar Metropolitano do Vale do Aço é a que apresenta a maior desproporção entre a população economicamente ativa e a dependente, seguida pelas RMs de Maceió (55\%) e São Luis (54\%).

A razão de dependência é uma medida que possibilita verificar a relação entre a população dependente (crianças e idosos) e a populaçăo economicamente ativa. Valores altos representam desvantagens econômicas para uma determinada região, pois a populaçăo em idade produtiva sustenta uma grande proporção de dependentes. Porém, esse indicador pode ocultar a exploraçăo de trabalho infantil ou a saida tardia do mercado de trabalho da população idosa.

Os valores encontrados para Razão de dependência, Razăo de Dependência Jovem, Razão de Dependência de Idosos e Porcentagem da Populaçăo de 15 a 50 anos, indicam que a RM do Vale do Aço-Colar é a que tem a maior desproporção entre a sua população jovem, adulta e idosa. Em seguida, encontram-se as RM de Maceió e São Luiz. 


\section{Estrutura por sexo e idade}

O uso da pirâmide populacional permite a análise da distribuição de uma população por sexo e dos diferentes grupos etários (Berquó 1980). Para a sua construção, utilizamos os percentuais, que possibilitam a comparação de populações com totais distintos.

$\mathrm{Na}$ RM do Norte/Nordeste de Santa Catarina-núcleo, a pirâmide tem o formato típico de barril, que representa regiões com baixa natalidade e mortalidade da população, razão de dependência baixa e idade mediana elevada.

Pirâmide Populacional do Núcleo da RM do N/NE de Santa Catarina. 2002

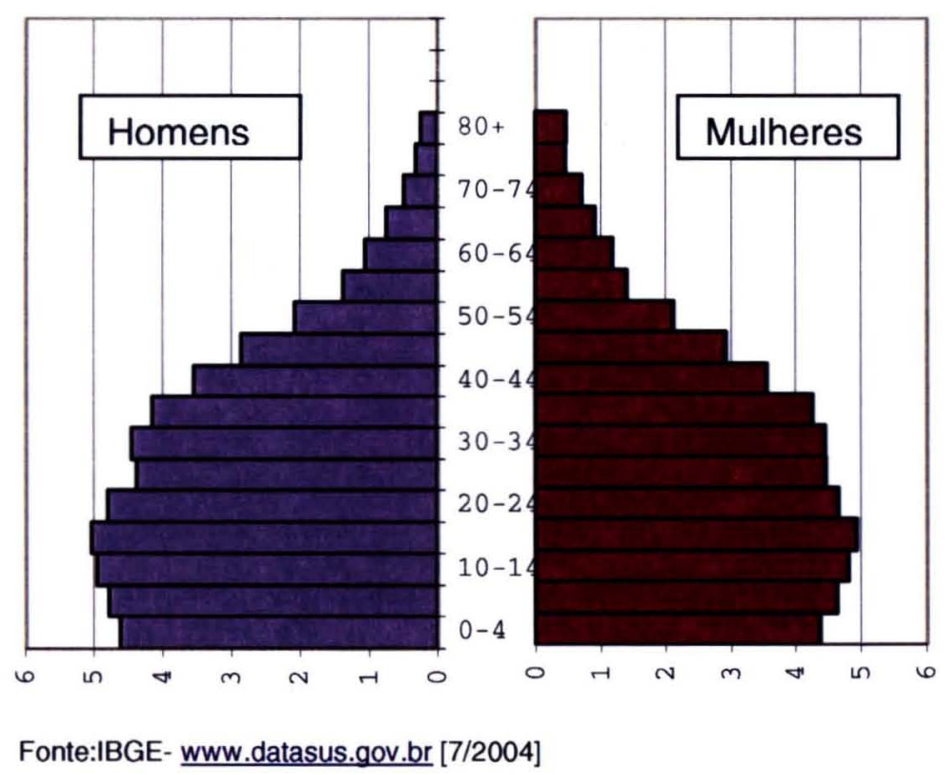

Na RM de Campinas também observamos que o formato da pirâmide segue a forma de barril, porém apresenta uma maior proporção no grupo etário de 15 a 19 e de 20 a 24, talvez fruto de uma imigração tanto feminina, quanto masculina. Nessa região também ocorre uma redução da fecundidade e da mortalidade. 
Pirâmide Populacional da RM de Campinas.2002

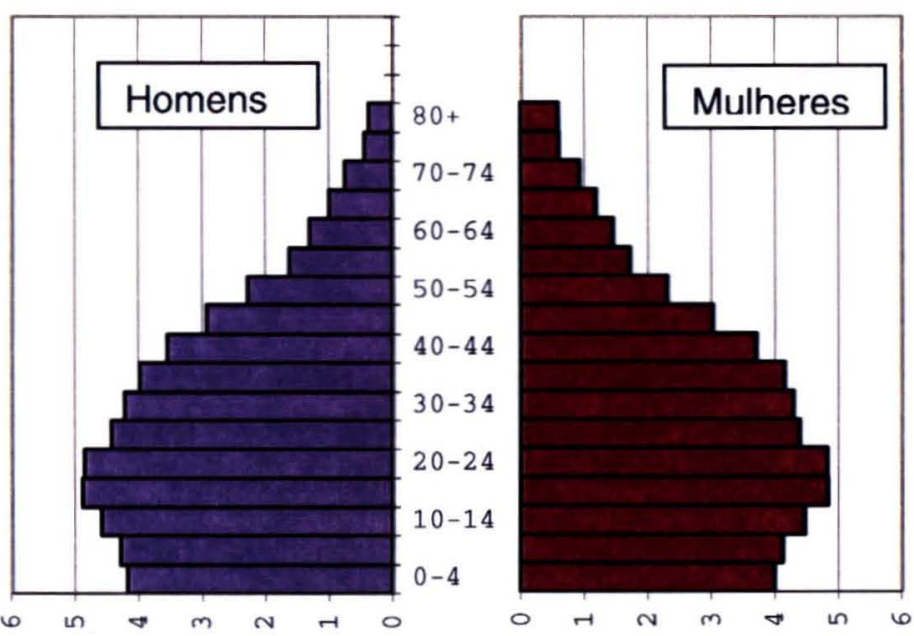

Fonte:IBGE- www.datasus.gov.br [7/2004]

$\mathrm{Na}$ pirâmide de Porto Alegre observamos uma redução da fecundidade, porém como foi verificado na RM de Campinas, as barras dos grupos etários de 15 a 19 e 20 a 24 apresentam maior proporção, que pode ocorrer devido a uma atração de população de ambos sexos para essa região. Podemos dizer, ainda, que a razão de dependência é baixa, sendo que o maior peso está na população com idades mais avançadas.

Pirâmide Populacional da RM de Porto Alegre.2002

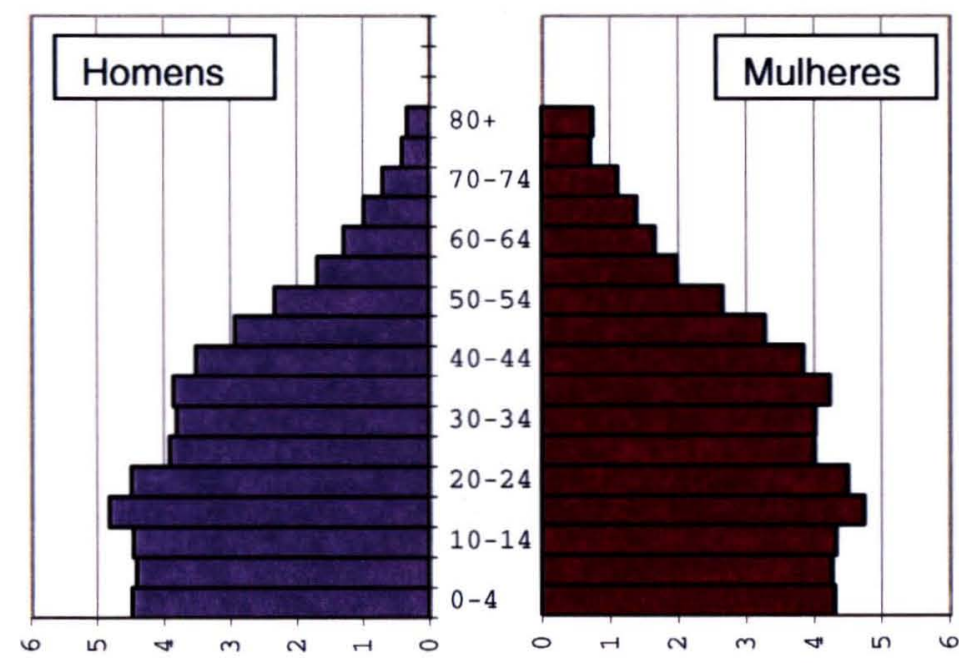

Fonte:IBGE- www.datasus.gov.br [7/2004]

$\mathrm{Na}$ RM de São Luis a redução da fecundidade foi um fenômeno mais recente do que nas RMs anteriores, porém mais irregular. Observamos 
ainda que, no grupo de 15 a 19 anos, a barra feminina é maior que a masculina. Isso pode ocorrer por uma maior mortalidade ou emigração dos homens desse grupo.

Pirâmide populacional da RM de São Luis. 2002
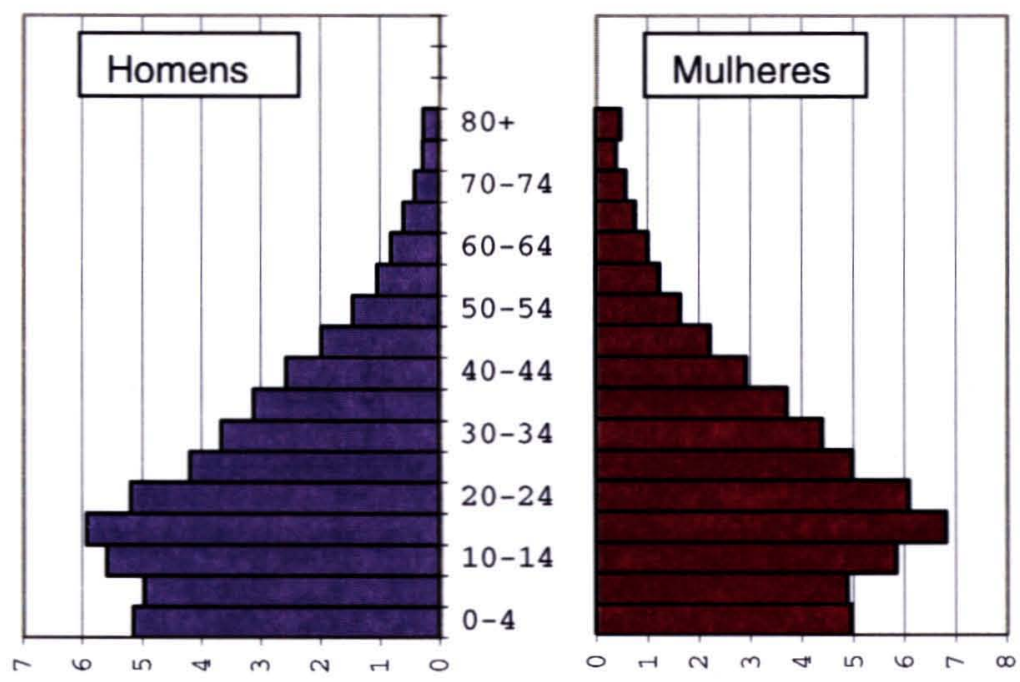

Fonte:IBGE- www.datasus.gov.br [7/2004]

$\mathrm{Na}$ RM de Maceió se observa que o grupo 0 a 4anos apresenta uma barra maior que o grupo seguinte. Isso pode ocorrer pelo aumento dos nascimentos ou por uma alta mortalidade infantil. 
Pirâmide Populacional da RM de Maceió. 2002.

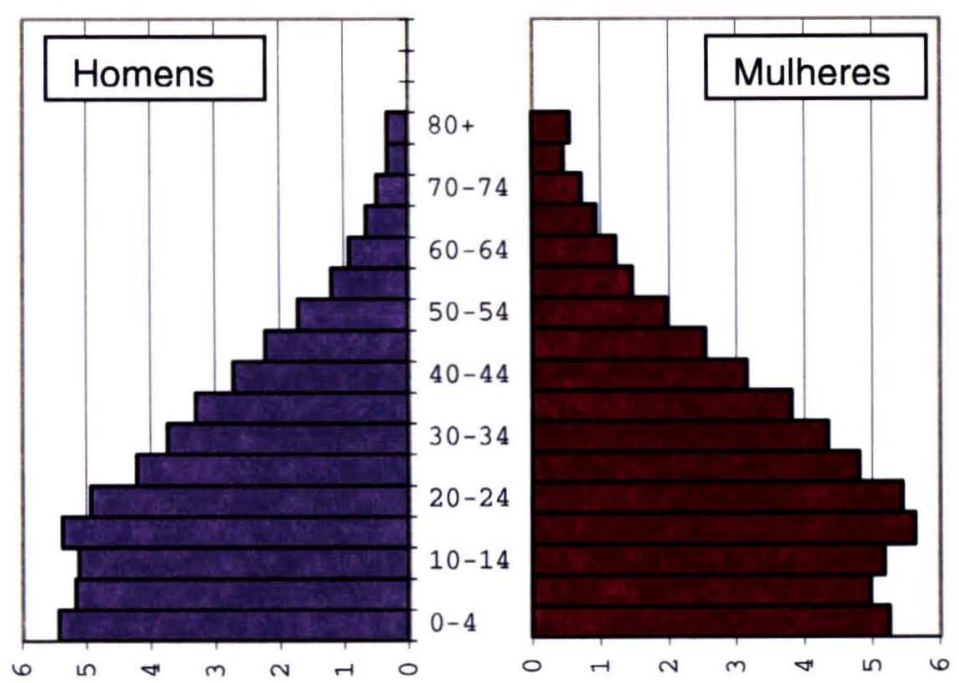

Fonte:IBGE- www.datasus.gov.br [7/2004]

$\mathrm{Na}$ RM do Vale do Aço-colar observamos uma redução da fecundidade acentuada e recente. Na faixa etária de 15 a 19 verificamos uma maior proporção da população masculina, que pode ocorrer pela emigração feminina ou imigração masculina.

Figura 7: Pirâmide Populacional do Colar Metropolitano da RM do Vale do Aço. 2002.
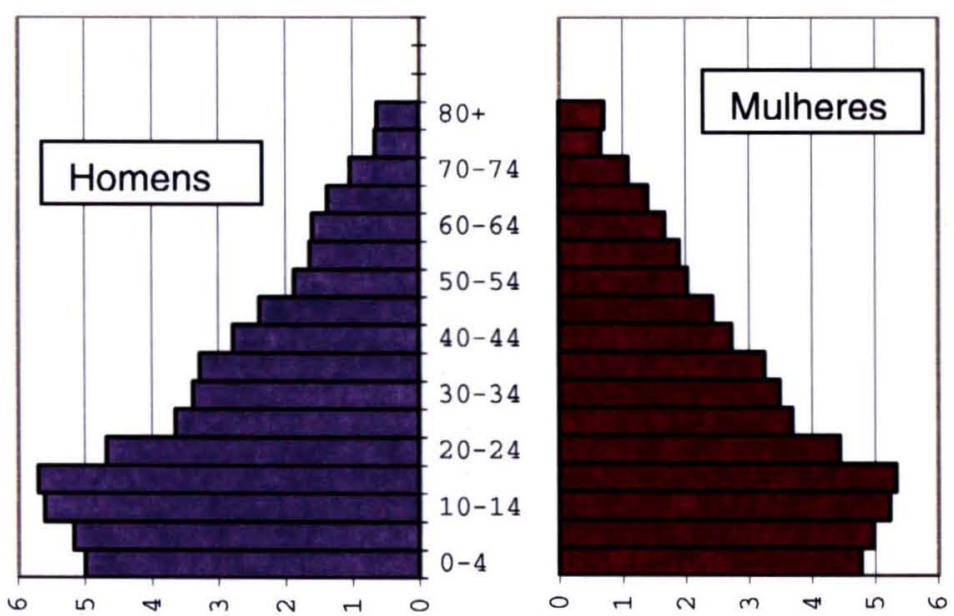

Fonte:IBGE- www.datasus.gov.br [7/2004] 
Em todas as regiōes, ao observarmos as pirâmides populacionais, verificamos uma redução da fecundidade e da mortalidade. Porém, em momentos distintos, em algumas regióes de forma mais regular $e$ homogênea, como em Santa Catarina e Campinas e, em outras, de forma mais irregular, como em Maceió e Såo Luiz.

\section{Fecundidade e crescimento populacional}

Quando comparamos a Taxa de Fecundidade Geral para as RM selecionadas, observamos que a região do Vale do Aço-Colar apresentou um valor inferior aos das RMs de Maceió e São Luis, que se assemelham mais ao perfil esperado para regiōes com um menor nivel socioeconômico.

A maior Taxa de Fecundidade Geral (por mil mulheres) encontrada, para 0 ano de 2001, foi na RM de Maceió $(69,7)$, seguida pela RM de São Luis $(66,4)$, RM do Vale do Aço-Colar $(57,8)$, RM de Porto Alegre $(57,3)$, RM do N/NE de Santa Catarina $(56,4)$ e, por fim, a RM de Campinas $(56,4)$. Vale lembrar que esse indicador, por se tratar de uma taxa geral, sofre influência da estrutura etária da população.

Ao analisarmos as taxas especificas por grupos de idades, observamos que os valores mais elevados aparecem no grupo etário de 20 a 29 anos, nas RMs de Maceió $(114,6)$, RM de São Luis $(110,2)$ e RM do Vale do Aço-Colar (101). No grupo seguinte, de 30 a 39 anos, aparecem as RMs de Porto Alegre $(56,4)$, do N/NE de Santa Catarina $(45,9)$ e de Campinas $(45,9)$, com valores superiores.

Para o grupo de 10 a 14 anos, conforme o quadro apresentado a seguir, a RM de Maceió aparece com o maior valor $(4,6)$, enquanto que a RM do Colar $(0,9)$, apresentou o menor valor, entre as RMs selecionadas. 
Tabela 7: Taxa especifica de fecundidade e Taxa de fecundidade geral (por mil mulheres da faixa etária). Regiőes metropolitanas - 2001.

\begin{tabular}{|c|c|c|c|c|c|c|}
\hline Regiōes Metropolitanas & 10 a 14 & 15 a 19 & 20 a 29 & 30 a 39 & 40 a 49 & TFG* \\
\hline $\begin{array}{l}\text { Núcleo da RM do N/NE Sta } \\
\text { Catarina }\end{array}$ & 1,5 & 61,6 & 95,7 & 50,5 & 5,0 & 56,4 \\
\hline RM de Campinas & 1,7 & 55,7 & 89,4 & 45,9 & 4,0 & 51,6 \\
\hline RM de Porto Alegre & 3,1 & 68,3 & 94,0 & 56,4 & 7,2 & 57,3 \\
\hline RM de Săo Luis & 3,3 & 80,5 & 110,2 & 34,8 & 3,0 & 66,4 \\
\hline $\begin{array}{l}\text { RM de Maceió } \\
\text { Colar Metropolitano da RM do }\end{array}$ & 4,6 & 96,1 & 114,6 & 40,7 & 4,1 & 69,7 \\
\hline 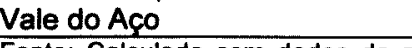 & 0,9 & 57,4 & 101,0 & 44,8 & 7,2 & 57,8 \\
\hline
\end{tabular}

Apesar de números altos de fecundidade encontrados para alguns grupos etários nas diferentes regiões, a Taxa de Fecundidade Total, que tem como hipótese que a fecundidade é constante no tempo, revela que em todas elas o valor desse indicador está abaixo de 2,1 filhos por mulher, número considerado necessário para a reposição populacional. A RM de Campinas é a que tem a menor taxa $(0,98)$, seguida pela RM do Vale do Aço-Colar (1,05), RM do N/Ne de Santa Catarina-Núcleo $(1,07)$, RM de Porto Alegre $(1,15)$, RM de São Luis $(1,16)$ e RM de Maceió $(1,30)$.

Tabela 8: Taxa de crescimento da população para os periodos 1991-2000, 2000-2001 e 2001-2002 nas Regiőes metropolitanas selecionadas.

\begin{tabular}{lccc}
\hline Região Metropolitana & $1991-2000$ & $2000-2001$ & $2001-2002$ \\
\hline RM do N/NE Catarinense & 2,52 & 2,33 & 1,82 \\
RM de Campinas & 2,56 & 2,49 & 1,96 \\
RM de Porto Alegre & 1,59 & 1,63 & 1,28 \\
RM de São Luís & 3,03 & 2,85 & 2,23 \\
RM de Maceió & 2,60 & 2,43 & 1,89 \\
Colar do Vale do Aço & 0,92 & 0,50 & 0,46 \\
\hline Fonte: IBGEJCenso, contagem populacional e projeçōes demográficas \\
preliminares
\end{tabular}

Conforme se observa na tabela apresentada, ocorre também um declínio nas taxas de crescimento das populações nas regiões estudadas, chamando a atenção o baixo valor encontrado para a RM do Vale do AçoColar: 0,46 no periodo de 2001-2002. Essa taxa reflete a dinâmica dos 
fatores demográficos, ou seja, a natalidade, mortalidade e movimentos migratórios.

\section{Mortalidade}

Os dados de mortalidade aqui apresentados são do Sistema de Informação de Mortalidade-SIM para o ano de 2002, que foram obtidos no site do DATASUS.

Taxa Bruta e Especifica de Mortalidade

A RM de Porto Alegre foi a que apresentou a maior taxa bruta de mortalidade (6,5/1000); e na seqüência, a RM de Maceió (5,8/1000), RM de Campinas (5,6/1000), Colar Metropolitano do Vale do Aço (5/1000), N/NE de Sta Catarina $(4,4 / 1000)$ e RM de São Luis (4,3/1000). Para o Brasil, segundo - IDB2000 (DATASUS 2005) a Taxa Bruta de Mortalidade foi de 6,63 por mil habitantes, exceto pela RM de Porto Alegre, todas as demais estão abaixo desse valor, como se pode observar, essa taxa não revela as diferenças existentes entre as regiões selecionadas. Tal fato ocorre, primeiro, pela má qualidade dos dados em algumas regiões do País, segundo, porque a taxa Bruta de Mortalidade é um indicador que sofre forte influência da estrutura de uma população, tanto da idade quanto do sexo.

Tabela 9: Taxa Bruta de mortalidade e taxa especifica por sexo. Regiōes Metropolitanas. 2002

\begin{tabular}{lccc}
\hline $\begin{array}{c}\text { Regiåo } \\
\text { Metropolitana }\end{array}$ & masculina feminina & Total \\
\hline N/NE de Sta Cat. & 5,3 & 3,5 & 4,4 \\
Campinas & 6,8 & 4,3 & 5,6 \\
Porto Alegre & 7,4 & 5,6 & 6,5 \\
S Luis & 5,1 & 3,6 & 4,3 \\
Maceió & 6,9 & 4,8 & 5,8 \\
Colar do Vale do Aço & 5,7 & 4,3 & 5,0 \\
\hline
\end{tabular}

Fonte: SIM/DATASUS (2004)

Na tabela 9, observa-se que a sobre-mortalidade masculina está presente também nas regiōes estudadas. Na RM de Campinas os óbitos masculinos foram $57 \%$ superiores ao feminino; na RM do N/NE de Santa 
Catarina, 50\%; na RM de Maceió, 45\%; na RM de São Luis, 40\%; e nas RMs de Porto Alegre e do Colar Metropolitano do Vale do Aço, 33\%.

Devido à influência da Taxa Bruta de Mortalidade pela estrutura etária, analisamos os diferentes grupos etários, buscando identificar quais grupos teriam maior mortalidade nas diferentes regiōes.

Tabela 10: Taxa específica de mortalidade por idade (mil habitantes). Regiões Metropolitanas, 2002.

\begin{tabular}{|l|c|c|c|c|c|c|}
\hline Falxa Etaria & $\begin{array}{c}\text { N/NE de Sta } \\
\text { Catarina }\end{array}$ & $\begin{array}{c}\text { RM de } \\
\text { Campinas }\end{array}$ & $\begin{array}{c}\text { RM de Porto } \\
\text { Alegre }\end{array}$ & $\begin{array}{c}\text { RM de S\%ols } \\
\text { Luls }\end{array}$ & $\begin{array}{c}\text { RM de } \\
\text { Maceló }\end{array}$ & $\begin{array}{c}\text { RM Vale do } \\
\text { Aços-Colar }\end{array}$ \\
\hline Menor 1 ano & 8,9 & 11,1 & 12,2 & 21,6 & 23,5 & 21,6 \\
\hline 1 a 4 anos & 0,5 & 0,6 & 0,6 & 1,1 & 0,9 & 0,2 \\
\hline 5 a 14 anos & 0,3 & 0,3 & 0,3 & 0,3 & 0,4 & 0,3 \\
\hline 15 a 24 anos & 1,0 & 1,7 & 1,4 & 1,0 & 1,8 & 0,9 \\
\hline 25 a 34 anos & 1,4 & 1,9 & 2,1 & 1,7 & 2,2 & 1,3 \\
\hline 35 a 44 anos & 2,4 & 2,7 & 3,0 & 2,7 & 3,7 & 2,5 \\
\hline 45 a 54 anos & 5,2 & 5,7 & 6,8 & 6,4 & 7,4 & 5,7 \\
\hline 55 a 64 anos & 14,9 & 12,3 & 15,1 & 13,5 & 16,7 & 10,5 \\
\hline 65 e mais & 48,3 & 49,5 & 53,4 & 49,1 & 56,7 & 35,6 \\
\hline
\end{tabular}

$\mathrm{O}$ único padrão encontrado entre as RMs com mais alto IDH e aquelas com mais baixo, foi no grupo de menores de um ano. Neste grupo ficou evidente que as RMs com melhor IDH apresentaram taxas bem menores em comparação com as de baixo IDH. Para os menores de um ano; as maiores taxas encontradas foram para as RMs de Maceio $(23,5 / \mathrm{mil})$, São Luis $(23,5 / 1000)$ e do Colar Metropolitano do Vale do Aço, por outro lado as menores taxas foram nas RMs de Porto Alegre $(12,2 / 1000)$, de Campinas $(11,1 / 1000)$ e do N/NE de Santa Catarina $(8,9 / 1000)$.

Em alguns grupos etários, as RMs com pior IDH apresentaram menores taxas, porém não se pode afirmar que seja resultado de uma melhor qualidade de vida, pois talvez ocorram devido a subnotificação, problema que está presente no banco do SIM.

As taxas masculinas são superiores nas duas regiões, porém a diferença entre os sexos não segue um padrão para as RMs com alto ou baixo IDH. 


\section{Urbanização}

Quanto ao grau de urbanização, segundo dados do Anuário de Saúde (Datasus, 2004) no ano de $2000,81,3 \%$ da população brasileira vivia na zona urbana. Para as RMs estudadas, Campinas foi onde encontramos o maior grau de Urbanização, 97,1\% da população dessa região; na RM de Maceió, 96,6\%; na RM do N/NE de Santa Catarina-núcleo, 96,4\%; na RM de Porto Alegre, 95,5\%; na RM de São Luis, $82 \%$; e finalmente na RM do Vale do Aço-colar, 64\%. Essa última, a única que difere das demais e apresenta valor abaixo ao nacional.

\section{Analfabetismo}

Em todas as regióes, observa-se uma desvantagem feminina em relação à taxa de analfabetismo, indicador que mede o percentual de pessoas acima de 15 anos que não sabem ler e escrever.

Na RM do Vale do Aço-Colar depara-se com a maior taxa de analfabetismo da populaçăo maior de 15 anos, $20,2 \%$ no ano de 2000 , número superior à taxa nacional, que nesse mesmo ano foi de $13,6 \%$. A situação é ainda mais desfavorável para as mulheres, pois o valor desse indicador foi de $22,1 \%$, enquanto que a taxa nacional feminina ficou em $13,5 \%$. Para os homens dessa regiăo, a taxa esteve em $18,2 \%$, valor também superior à média nacional, que foi de $13,8 \%$. .

Tabela 11:Taxas de Analfabetismo da População de 15 Anos e Mais, por Sexo. Brasil e Regiōes Metropolitanas.2000.

\begin{tabular}{lrcc}
\hline Regloes Metropolitanas & Homens & Mulheres & Total \\
\hline Norte/Nordeste SC - Expansáo & 4,4 & 5,4 & 4,9 \\
Campinas & 4,9 & 7,0 & 6,0 \\
Porto Alegre & 4,2 & 5,3 & 4,8 \\
Såo Luis & 8,7 & 7,8 & 8,2 \\
Maceio & 19,3 & 20,0 & 19,7 \\
Vale do Aç - Colar Metropolitano & 18,2 & 22,1 & 20,2 \\
\hline BRASIL & 13,8 & 13,5 & 13,6 \\
\hline
\end{tabular}

Fonte: DATASUS/Fundaçăo IBGE. Censo Demográfico 
Em seguida, com valor próximo, 19,7\%, está a RM de Maceió. Para as mulheres, a taxa desse indicador foi de $20 \%$; e de $19,3 \%$ para os homens dessa região.

Em São Luis encontramos uma taxa bem inferior: $8,2 \%$, sendo a taxa feminina de $7,8 \%$ e a masculina de $8,7 \%$.

Na RM de Campinas, conforme quadro anterior, a taxa foi de $6 \%$, sendo o analfabetismo entre mulheres de $7 \%$ e entre homens de $4,9 \%$.

Na RM de Porto Alegre e do N/Ne da Santa Catarina, os valores foram muito próximos, ficando em 4,8 e 4,9, respectivamente. Na primeira região, a taxa para as mulheres foi de $5,3 \%$; e na segunda, de $5,4 \%$, sendo que para os homens foi $4,2 \%$ e $4,4 \%$.

\section{Indicadores socioeconômicos}

A taxa de desemprego é um indicador que mede o percentual da população residente economicamente ativa, acima de 10 anos de idade, que encontra-se sem trabalho.

Das RMs selecionadas para esse estudo, no ano de 2003, Maceió e Săo Luis, foram as que apresentaram os maiores valores para a taxa de desemprego, $23,57 \%$ e $21,42 \%$, respectivamente. A RM do Colar Metropolitano do Vale do Aço apresentou uma taxa de $17,35 \%$, valor também superior à média nacional, que foi de $15,28 \%$, no mesmo período. Além dessas, ainda, um pouco acima da média nacional encontramos as RMs de Campinas, com $16,26 \%$, e a RM do N/NE de Santa Catarina, com 15,57. A RM de Porto Alegre foi a que apresentou a menor taxa de desemprego: 14,94\%. (Tabela 12) 
Tabela 12: Taxa de desemprego e massa de rendimento. Regiőes Metropolitanas. 2003.

\begin{tabular}{|c|c|c|c|}
\hline $\begin{array}{l}\text { Regišo } \\
\text { Metropolitana }\end{array}$ & $\begin{array}{l}\text { Taxa de } \\
\text { desemprego }{ }^{1}(\%)\end{array}$ & $\begin{array}{l}\text { Massa } \\
\text { rendimento } \\
1000 \text { ) }\end{array}$ & $\begin{array}{r}\text { de } \\
\text { (R\$ }\end{array}$ \\
\hline $\begin{array}{l}\text { N/Ne de Santa } \\
\text { Catarina } \\
\text { Campinas } \\
\text { Porto Alegre } \\
\text { Sảo Luis } \\
\text { Maceió } \\
\text { CM da RM do vale } \\
\text { do Aço } \\
\text { Brasil }\end{array}$ & $\begin{array}{l}15,57 \\
16,26 \\
14,94 \\
21,42 \\
23,57 \\
17,35 \\
15,28\end{array}$ & $\begin{array}{l}179.474 \\
1.091 .659 \\
1.699 .966 \\
215745 \\
241.372 \\
20415\end{array}$ & \\
\hline
\end{tabular}

Fonte IBGE-Censo Demografico; PNUD- Atlas do Desenvolvimento Humano, 2003;. (Moura, 2004)

(1) Proporçáo do numero de desempregados sobre o total da PEA

(2) Considera todas as formas de rendimento declaradas pelas pessoas ao

Censo Demográfico; o indicador foi construido a partir dos dados de populaçăo total e renda municipal per capita, do Atlas de Desenvolvimento Humano

O Observatório das Metrópoles-IPPUR/FASE elaborou um Indice de Carência na oferta de serviços essenciais à Habitação- $\mathrm{ICH}$. No seu cálculo foram considerados o abastecimento de água, a instalação sanitária e o destino do lixo. Os valores abaixo de 0,5 indicam situaçăo de "extrema carência"; entre 0,5 e menos de 0.8 , "alta carência"; e os valores entre 0.8 e 1,0 săo classificados como "baixa carência" (Moura 2004).

As RMs de Campinas $(0,882)$, Porto Alegre $(0.865)$ e do N/NE de Santa Catarina-núcleo $(0,813)$ foram classificadas como regiōes de baixa carência. A RM de São Luis $(0,554)$ como extrema carência. Para as RM de Maceió e do Colar metropolitano do Vale do Aço, năo foi disponibilizado o indicador. 
Tabela 13: ICH, Renda per capita domiciliar e Rendimento médio de todos os trabalhos

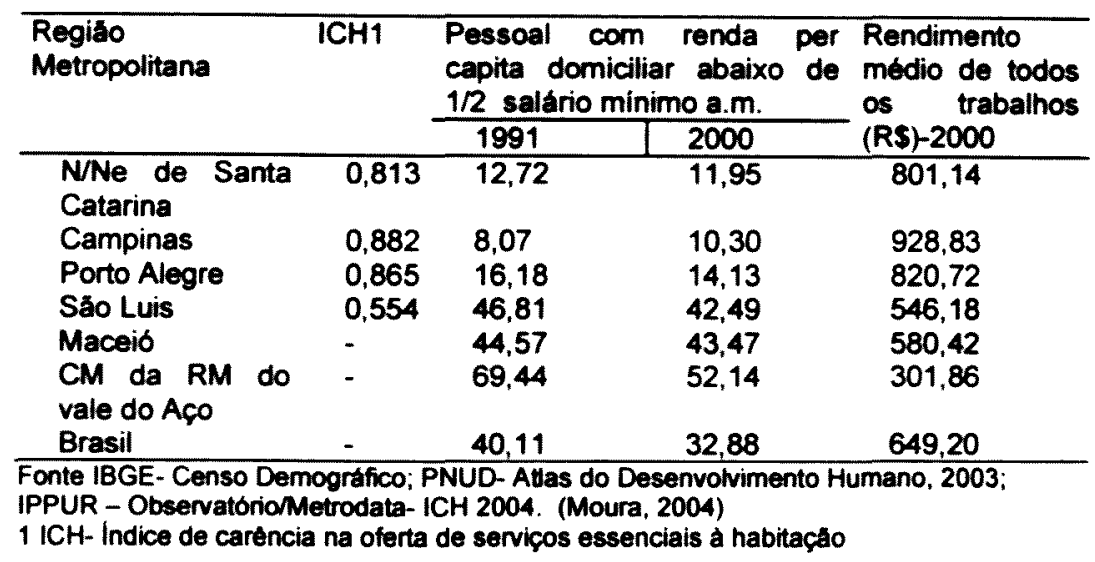

Em relação à renda domiciliar per capita, enquanto que no Brasil, nos dois períodos apresentados, ocorreu uma redução na porcentagem dos que vivem com meio salário mínimo, nas RM de Campinas e Porto Alegre elevou-se a proporçăo.

Por outro lado, as RMs de Săo Luis, Maceió, Colar Metropolitano do Vale do Aço e Núcleo da RM do N/NE de Santa Catarina, acompanharam a tendência de reduçăo nacional. Porém, nas três primeiras, ainda se observa valores altíssimos de pessoas com renda domiciliar abaixo de meio salário mínimo. (tabela 13)

\section{Oferta de Serviços e equipamentos de saúde}

Consideramos o acesso aos serviços de saúde um importante aspecto em um estudo da demanda hospitalar, porém, como alerta Pinheiro et al. (2002), esse conceito é de difícil definiçăo e relaciona-se à percepçăo que cada pessoa tem de sua necessidade em saúde, que se converte em demanda e uso. Por fim, os "fatores ligados à oferta podem facilitar ou reprimir o acesso" (p.689).

Usando como fonte de dados a pesquisa do IBGE de Assisténcia Medico Sanitária 2002 (AMS-2002) e o site do DATASUS (2004), buscamos 
traçar um perfil da oferta de serviços e equipamentos de saúde nas distintas regiōes. Devido à diferença no tamanho das populações, em vez de analisarmos os números absolutos, optamos por utilizar taxas para avaliar a disponibilidade dos serviços.

A primeira constatação foi a maior oferta de estabelecimentos com internação nas regiōes com o mais baixo IDH, exceto na RM do Colar Metropolitano do Vale do Aço, que tem como referência, provavelmente, os serviços oferecidos na RM do Vale do Aço (tabela 14).

Tabela 14: Taxa de estabelecimentos de saúde por 100 mil habitantes, segundo tipos de atendimento e Regiōes Metropolitanas. 2002

\begin{tabular}{|c|c|c|c|c|}
\hline $\begin{array}{c}\text { Regióces } \\
\text { Metropolitanas }\end{array}$ & $\begin{array}{l}\text { Estab. Com } \\
\text { internaçalo }\end{array}$ & $\begin{array}{l}\text { Estab. sem } \\
\text { internaçäo }\end{array}$ & $\begin{array}{c}\text { Estab. } \\
\text { Apolo a } \\
\text { diagnose } \\
\text { terapia }\end{array}$ & $\begin{array}{c}\text { Total de } \\
\text { estabelecimentos }\end{array}$ \\
\hline $\begin{array}{l}\text { RM Norte/Nordeste } \\
\text { Catarinense }\end{array}$ & 1,5 & 26,7 & 20,1 & 48,3 \\
\hline RM de Campinas & 2,6 & 14,9 & 6,8 & 24,3 \\
\hline RM de Porto Alegre & 1,8 & 17,3 & 8,4 & 27,5 \\
\hline $\begin{array}{l}\text { Região Metropolitana } \\
\text { de São Luis }\end{array}$ & 3,9 & 11,3 & 1,8 & 17,0 \\
\hline RM de Maceió & 4,1 & 11,4 & 3,0 & 18,5 \\
\hline $\begin{array}{l}\text { Colar da RM Vale do } \\
\text { Aço }\end{array}$ & 1,2 & 42,0 & 7,9 & 51,1 \\
\hline
\end{tabular}

Fonte: IBGE, Diretoria de Pesquisas, Departamento de Populaçáo e Indicadores Sociais.

Pesquisa de Assistencia Médica-Sanitária 2002

Por outro lado, observamos que para os estabelecimentos sem internação, bem como os de Apoio à diagnose e terapia, nas RMs do Núcleo do N/NE de Sta Catarina, Porto Alegre e Campinas, existe uma maior relaçăo de estabelecimentos por habitantes. Novamente o Vale do Aço aparece como exceção, pois é a RM com maior proporção de estabelecimentos sem serviços de internação (Tabela 14).

Quando analisamos os estabelecimentos com internação, por esfera administrativa, năo encontramos um padrăo para as RMs com mais alto ou baixo IDH. Na verdade, exceto pelo Colar da RM do Vale do Aço, com apenas 2 estabelecimentos, um de cada tipo, nas demais RMs, predominam os estabelecimentos privados (Tabela 15). 
Tabela 15: Estabelecimentos de saúde com internação por esfera administrativa, segundo Regiōes Metropolitanas. 2002

\begin{tabular}{|c|c|c|c|c|c|}
\hline $\begin{array}{l}\text { Regióes } \\
\text { Motropolitanas }\end{array}$ & Público & $\%$ & Privado & $\%$ & Total \\
\hline $\begin{array}{l}\text { RM N/Ne de Sta } \\
\text { Catarina }\end{array}$ & 3 & 42,9 & 4 & 57,1 & 7 \\
\hline RM de Campinas & 9 & 14,3 & 54 & 85,7 & 63 \\
\hline RM de Porto Alegre & 20 & 28,6 & 50 & 71,4 & 70 \\
\hline RM de São Luis & 22 & 50,0 & 22 & 50,0 & 44 \\
\hline RM de Maceió & 11 & 26,2 & 31 & 73,8 & 42 \\
\hline RM Vale do Aço-colar & 1 & 50,0 & 1 & 50,0 & 2 \\
\hline
\end{tabular}

Quanto à categoria dos estabelecimentos com internação, no Colar Metropolitano do vale do Aço, os dois estabelecimentos existentes são gerais (Tabela16).

No Núcleo da RM do N/NE de Santa Catarina, dos sete estabelecimentos com internação, quatro têm algum tipo de especialidade, e três deles são gerais (tabela16).

Nas RMs do Núcleo do N/NE de Sta Catarina e do Colar Metropolitano do Vale do Aço, não encontramos registro de estabelecimentos de saúde com internação especializados. Para as demais RMs, quanto a essa categoria, em Maceió $29 \%$ dos estabelecimentos com internação são especializados; na RM de Campinas, são 25\%; em Porto Alegre, $19 \%$; e na RM de São Luis, $14 \%$.

A proporção dos estabelecimentos com algum tipo de especialidade foi de 55\% na RM de Maceió, 37\% na RM de Porto Alegre, $32 \%$ na RM de São Luis e $29 \%$ na RM de Campinas.

Na RM de São Luis 55\% dos estabelecimentos com internação são gerais. Em Campinas esta categoria representou $46 \%$ dos estabelecimentos, em Porto Alegre $44 \%$ e na RM de Maceió $17 \%$. 
Tabela 16 - Número de estabelecimentos de saúde por categoria e regime de atendimento, segundo Regiōes Metropolitanas. 2002

\begin{tabular}{lcccccc}
\hline $\begin{array}{c}\text { Regilă } \\
\text { Metropolitana }\end{array}$ & \multicolumn{2}{c}{ Especializado } & \multicolumn{2}{c}{ Com especialidades } & \multicolumn{2}{c}{ Geral } \\
\cline { 2 - 7 } & $\begin{array}{c}\text { Com } \\
\text { internaçăo }\end{array}$ & $\begin{array}{c}\text { Sem } \\
\text { internaçăo }\end{array}$ & $\begin{array}{c}\text { Com } \\
\text { internaçăo }\end{array}$ & $\begin{array}{c}\text { Sem } \\
\text { internaçăo }\end{array}$ & $\begin{array}{c}\text { Com } \\
\text { internaçắo }\end{array}$ & $\begin{array}{c}\text { Som } \\
\text { internaçăo }\end{array}$ \\
\hline RM N/Ne de Sta & - & 132 & 4 & 64 & 3 & 25 \\
Catarina & 16 & 175 & 18 & 319 & 29 & 36 \\
RM de Campinas & 13 & 378 & 26 & 392 & 31 & 212 \\
RM de Porto Alegre & 6 & 42 & 14 & 53 & 24 & 52 \\
RM de São Luis & 12 & 27 & 23 & 59 & 7 & 63 \\
RM de Maceió & - & 32 & - & 25 & 2 & 25 \\
RM Vale do Aço-colar & - & &
\end{tabular}

Fonte: IBGE, Diretoria de Pesquisas, Departamento de Populaçåo e Indicadores Sociais, Pesquisa de Assistencia Médico-Sanitária 2002.

O Colar Metropolitano da RM do Vale do Aço é a região mais desprovida de equipamentos de saúde. De acordo com a pesquisa AMS, no ano de 2002, os únicos equipamentos existentes eram o eletrocardiógrafo e o RX

Nas demais regiōes, os principais equipamentos encontrados foram o Eletrocardiógrafo, RX e Equipamentos de Hemodiálise.

Tabela 17: Taxa de equipamentos existentes em estabelecimentos de saúde por tipo e Regiōes Metropolitanas - 2002 (por 100000 habitantes)

\begin{tabular}{|c|c|c|c|c|c|c|c|c|c|}
\hline $\mathrm{RM}$ & $\begin{array}{l}\text { Mamb } \\
\text { grafo }\end{array}$ & $\begin{array}{l}\text { Raio } X \\
\text { para } \\
\text { densito } \\
\text { metria } \\
\text { bseea }\end{array}$ & $\begin{array}{l}\text { Tomo } \\
\text { grafo }\end{array}$ & $\begin{array}{l}\text { Resson } \\
\text { Ancia } \\
\text { magnoti } \\
\text { ca }\end{array}$ & \begin{tabular}{|l|} 
Jitra- \\
som \\
dopller \\
colorido
\end{tabular} & $\begin{array}{l}\text { Eletroca } \\
\text { coliograf } \\
0\end{array}$ & $\begin{array}{l}\text { Eletroe } \\
\text { ncofalo } \\
\text { grafo }\end{array}$ & $\begin{array}{l}\text { Equipa } \\
\text { mento } \\
\text { de } \\
\text { hemodl } \\
\text { bliee }\end{array}$ & $R x$ \\
\hline $\begin{array}{l}\text { N/NE de Sta } \\
\text { Catarina }\end{array}$ & 0,64 & 0,42 & 0,85 & 0,21 & 2,97 & 8,06 & 0,64 & 8,90 & 8,27 \\
\hline $\begin{array}{l}\mathrm{RM} \text { de } \\
\text { Campinas }\end{array}$ & 09 & 0,53 & 1,39 & 0,41 & 3,08 & 15,38 & 1,64 & 9,31 & 11,28 \\
\hline $\begin{array}{l}\text { RM de Porto } \\
\text { Alegre }\end{array}$ & 38 & 0,65 & 1,59 & 0,50 & 3,27 & 10,87 & 2,17 & 11,50 & 10,48 \\
\hline $\begin{array}{l}\text { RM de Sáo } \\
\text { Luis }\end{array}$ & 1,60 & 0,45 & 1,42 & 0,89 & 2,67 & 5,96 & 2,14 & 8,37 & 9,97 \\
\hline RM de Maceió & 23 & 0,58 & 0,97 & 0,10 & 2,81 & 7,27 & 0,87 & 10,76 & 7,27 \\
\hline $\begin{array}{l}\text { Colar } \\
\text { Metropolitano } \\
\text { da RM do Vale } \\
\text { do Aço }\end{array}$ & - & - & - & - & - & 1,83 & - & - & 0,61 \\
\hline
\end{tabular}

Fonte: IBGE, Diretoria de Pesquisas, Departamento de Populaçăo e Indicadores Sociais, Pesquisa de Assisténcia Médico-Sanitária 2002

Quanto à disponibilidade de equipamentos ao SUS, no Colar Metropolitano da RM do Vale do Aço, o único é o Eletrocardiógrafo. 
Nas demais RMs, comparadas as taxas de equipamentos existentes e os disponiveis ao SUS, em cada uma delas, observamos uma grande diferença entre o que tem na região e o que o usuário do SUS tem acesso.

Quando comparamos as taxas de equipamentos existentes no SUS, entre as RMs, verificamos que diminuem as diferenças de disponibilidade entre as regiōes com pior e melhor IDH. No caso do mamógrafo e RX para densitometria óssea, nas RMs de Maceió e São Luis, a oferta é superior à encontrada nas RMs de Campinas e Porto Alegre (tabela18).

Tabela 18:Taxa de Equipamentos existentes por habitantes, disponiveis ao SUS, em estabelecimentos de saúde, por tipo, segundo Regiōes Metropolitanas - 2002 (por 100000 habitantes)

\begin{tabular}{|c|c|c|c|c|c|c|c|c|c|}
\hline $\mathbf{R M}$ & $\begin{array}{l}\text { Mamo } \\
\text { grafo }\end{array}$ & \begin{tabular}{|l|} 
Raio $X$ \\
para \\
densito \\
metria \\
besea \\
\end{tabular} & \begin{tabular}{|l|} 
Tomóg \\
rafo
\end{tabular} & $\begin{array}{l}\text { Ressonán } \\
\text { cia } \\
\text { magnótic } \\
\text { a }\end{array}$ & $\begin{array}{l}\text { Ultra- } \\
\text { som } \\
\text { dopller } \\
\text { colorido }\end{array}$ & $\begin{array}{l}\text { Eletroc } \\
\text { ardiógr } \\
\text { afo }\end{array}$ & $\begin{array}{l}\text { Eletroe } \\
\text { ncefalo } \\
\text { grafo }\end{array}$ & $\begin{array}{l}\text { Equipa } \\
\text { mento } \\
\text { de } \\
\text { hemodi } \\
\text { flise }\end{array}$ & $\overline{R X}$ \\
\hline $\begin{array}{l}\text { N/NE de Sta } \\
\text { Catarina }\end{array}$ & 0,21 & 0,21 & 0,42 & - & 1,27 & 4,88 & - & 6,78 & 4,88 \\
\hline RM de Campinas & 0,49 & 0,12 & 0,45 & 0,04 & 0,70 & 10,01 & 0,94 & 8,98 & 5,05 \\
\hline RM de Porto Alegre & 0,42 & 0,08 & 0,63 & 0,03 & 0,81 & 5,46 & 0,81 & 10,79 & 5,15 \\
\hline RM de Sảo Luis & 0,80 & 0,18 & 0,80 & 0,45 & 0,98 & 2,23 & 1,07 & 8,28 & 5,43 \\
\hline RM de Maceió & 1,26 & 0,29 & 0,58 & - & 0,39 & 4,94 & 0,48 & 7,95 & 4,75 \\
\hline $\begin{array}{l}\text { Colar Metropolitano } \\
\text { da RM do Vale do } \\
\text { Aço }\end{array}$ & - & - & - & - & - & 1,83 & - & - & - \\
\hline
\end{tabular}

A maior oferta de leitos para a população, 3,76 por mil habitantes, encontramos na RM de Maceió; em seguida, aparecem: a RM de São Luis, com uma taxa de 3,07; Porto Alegre, com 2,72; Campinas, com 2,11, N/NE de Sta Catarina, com 1,88 e Colar Metropolitano do Vale do Aço, com 0,37 (Tabela19).

Nas RMs de Campinas, Porto Alegre, São Luis e Maceió, o número de leitos privados, em relação à população, é maior que o número de leitos públicos (tabela19). 
Tabela 19: Taxa de leitos para internação em estabelecimentos de saúde, por esfera administrativa, segundo Regiōes Metropolitanas. 2002. (por 1000 habitantes)

\begin{tabular}{|c|c|c|c|}
\hline Região Metropolitana & Público & Privado & Total \\
\hline $\begin{array}{l}\text { RM do Norte/Nordeste } \\
\text { Catarinense }\end{array}$ & 1,12 & 0,76 & 1,88 \\
\hline RM de Campinas & 0,60 & 1,51 & 2,11 \\
\hline RM de Porto Alegre & 1,03 & 1,69 & 2,72 \\
\hline RM de Săo Luis & 1,39 & 1,68 & 3,07 \\
\hline RM de Maceió & 1,09 & 2,66 & 3,76 \\
\hline $\begin{array}{l}\text { RM Colar Metropolitano } \\
\text { do Vale do Aco }\end{array}$ & 0,21 & 0,15 & 0,37 \\
\hline
\end{tabular}

Quanto aos leitos disponiveis ao SUS, independentemente de serem públicos ou privados, nas RMs de São Luis e Maceió encontramos a maior oferta: na primeira, são 3,95 por 1000 habitantes; e, na segunda, 3,62 (Tabela 20).

Tabela 20: Taxa de leitos, disponíveis para o SUS, para internaçăo em estabelecimentos de saúde, segundo Regiōes Metropolitanas. 2002. (por 1000 habitantes)

\begin{tabular}{ll}
\hline Reg.Metropolitana & Taxa \\
\hline RM de São Luis & 3,95 \\
RM de Maceió & 3,62 \\
Colar do Vale do Aço & 0,37 \\
RM de Campinas & 1,87 \\
RM do N/NE Catarinense & 1,30 \\
RM de Porto Alegre & 2,46 \\
\hline Fonte: wWW. datasus.gov.br [12/09/2004]
\end{tabular}

O acesso aos estabelecimentos de internação financiados pelo SUS também é diferenciado nas regiōes estudadas. As maiores taxas de internação foram nas RMs de São Luis $(7,35)$, seguindo-se Maceió $(7,71)$ e Colar da RM do Vale do Aço $(7,15)$. A taxa de internação no SUS, na RM de Maceió, é $34 \%$ superior à menor taxa, que foi encontrada no Núcleo da RM do N/NE de Santa Catarina $(5,09)$ (Tabela21). 
Tabela 21: Taxa de internação financiada pelo SUS segundo Região Metropolitana. 2002. (por 100 mil habitantes)

\begin{tabular}{ll}
\hline Reg.Metropolitana & Taxa \\
\hline RM de São Luis & 7,35 \\
RM de Maceió & 7,71 \\
Colar do Vale do Aço & 7,15 \\
RM de Campinas & 5,33 \\
RM do N/NE Catarinense & 5,09 \\
RM de Porto Alegre & 6,97 \\
\hline Fonte:SIH/DATASUS (2004)
\end{tabular}

O único registro sobre atendimento ambulatorial foi a média de consultas no SUS. Na RM de São Luis $(3,98)$ foi onde encontramos o maior valor para esse indicador, seguida pela RM de Campinas $(3,23)$, Maceió $(2,94)$, Porto Alegre $(2,62)$, Colar do Vale do Aço $(1,95)$ e N/NE de Santa Catarina $(1,81)$. Seria interessante verificar esse dado por sexo, porém o mesmo não se encontra disponível.

Tabela 22: Média de consultas SUS por 1000 habitantes.2002

\begin{tabular}{lr}
\hline Reg.Metropolitana & Consultas/hab \\
\hline RM de São Luis & 3,98 \\
RM de Maceió & 2,94 \\
Colar do Vale do Aço & 1,95 \\
RM de Campinas & 3,23 \\
RM do N/NE Catarinense & 1,81 \\
RM de Porto Alegre & 2,62 \\
\hline Fonte: WWW.datasus.gov.br [12/09/2004] &
\end{tabular}

Enquanto as maiores taxas de internações financiadas pelo SUS aparecem nas RMs com IDH mais baixo, ao analisarmos dados de saúde suplementar, são as RMs com IDH mais alto as que apresentam as maiores porcentagens de cobertura da população dos planos e seguros privados. 
Tabela 23: Porcentagem da população assistida por planos e seguros privados de saúde suplementar, segundo Regiões Metropolitanas. 2002

\begin{tabular}{lc}
\hline Reg.Metropolitana & \% pop. assistida \\
\hline RM de São Luís & 14,7 \\
RM de Maceió & 12,3 \\
Colar do Vale do Aço & 3,02 \\
RM de Campinas & 40,2 \\
RM do N/NE Catarinense & 33,5 \\
RM de Porto Alegre & 21,9 \\
\hline
\end{tabular}

Fonte: WuW.datasus.gov.br [12/09/2004]

Na RM de Campinas $40 \%$ da população têm cobertura de saúde suplementar, no Núcleo da RM do N/NE de Santa Catarina, 33,5\%; e na RM de Porto Alegre, $21,9 \%$ (Tabela 23).

No próximo capítulo, comparamos os resultados das taxas de internação masculina e femininas, nas Regiōes metropolitanas selecionadas. 


\section{Capitulo V Morbidade Hospitalar}

Conforme foi dito anteriormente, selecionamos as AlHS de tipo1, correspondentes às internações de homens e mulheres na faixa etária de 15 a 49 anos das Regiões Metropolitanas de Porto Alegre, Campinas, São Luis, Maceió, Núcleo da RM do N/NE de Santa Catarina e Colar Metropolitano do Vale do Aço (Anexo 5).

As proporções deste grupo etário no total de internações, incluindo os dois tipos de $\mathrm{AlH}$, nas regiões escolhidas foram distintas. Na RM de São Luis as internações do grupo de 15 a 49 anos representou $63 \%$ do total de internações; no N/NE de Sta Catarina, 56,7\%; em Campinas, 54,8\%; em Maceió, 53\%; nas RMs de Porto Alegre e Colar Metropolitano do Vale do Aço, $49,6 \%$ e 49,3\%, respectivamente (Gráfico 4).

Gráfico 4: Proporção de internações do grupo de 15 a 49 anos do total de internações. Regiões metropolitanas, 2002.

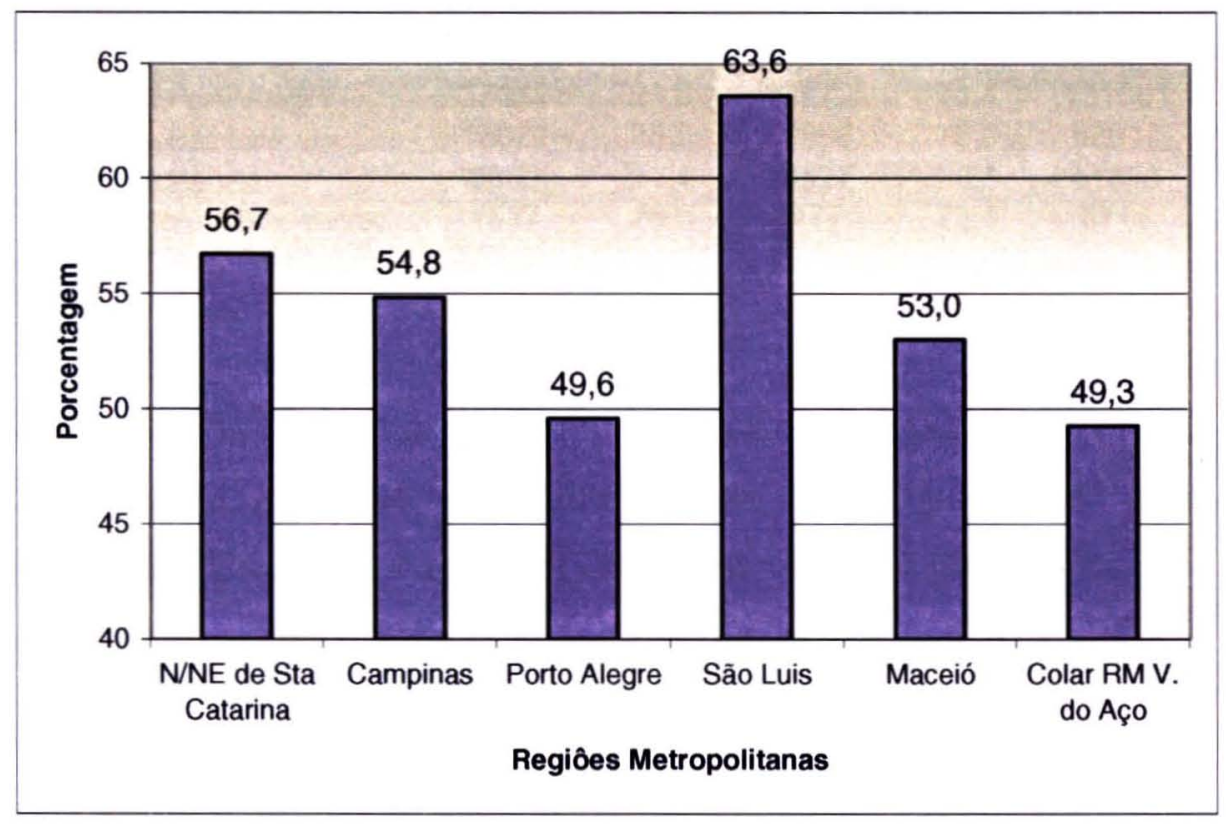

Fonte: MS/SAS/DATASUS, 2002.

Em todas as RMs, a proporção de AlHs de tipo 1 foi superior a de tipo 5. O Núcleo da RM do N/NE de Sta Catarina e a RM de Porto Alegre foram as regiōes que apresentaram as maiores proporções de internações com 
AlH de tipo 1. Por outro lado, a RMs de Maceió e Campinas, foram as que apresentaram as maiores porcentagens de AlHs de tipo 5 (Tabela 24).

Tabela 24: AlHs do grupo etário de 15 a 49 anos, por tipo e Regióes Metropolitanas. 2002

\begin{tabular}{lccccc}
\hline Regiăo Metropolitana & AlH I & $\%$ & AlH 5 & $\%$ & total \\
\hline Núcleo da RM do N/NE de & 13601 & 98,8 & 160 & 1,2 & 13761 \\
Sta Catarina & 70805 & 94,0 & 4510 & 6,0 & 75315 \\
RM de Campinas & 131601 & 98,6 & 1814 & 1,4 & 133415 \\
RM de Porto Alegre & 52017 & 95,5 & 2450 & 4,5 & 54467 \\
RM de São Luís & 41396 & 93,5 & 2860 & 6,5 & 44256 \\
RM de Maceió & 5714 & $\mathbf{9 6 , 8}$ & 190 & 3,2 & 5904 \\
\hline
\end{tabular}

Fonte: MS/SASIDATASUS, 2002.

Do total de AlHs de tipo 1, as RMs de Maceió, São Luis e Colar Metropolitano do Vale do Aço foram as que apresentaram as maiores proporções de internações femininas (Tabela 25).

Tabela 25: AlHs de tipo 1, por sexo e Regiōes Metropolitanas. 2002

\begin{tabular}{lccccc}
\hline Regiảo Motropolitana & Masculino & $\%$ & Feminino & $\%$ & Total \\
\hline Núcleo da RM do N/NE & 3787 & 27,8 & 9814 & 72,2 & 13601 \\
de Sta Catarina & 22393 & 31,6 & 48412 & 68,4 & 70805 \\
RM de Campinas & 37629 & 28,6 & 93972 & 71,4 & 131601 \\
RM de Porto Alegre & 13021 & 25,0 & 38996 & 75,0 & 52017 \\
RM de São Luís & 8869 & 21,4 & 32527 & 78,6 & 41396 \\
RM de Maceió & 1537 & 26,9 & 4177 & 73,1 & 5714 \\
V.do Aço-colar metrop & 150 & & & &
\end{tabular}

Fonte: MSISAS/DATASUS, 2002.

Nas RMs do Colar Metropolitano do Vale do Aço, Núcleo do N/NE de Sta Catarina e Campinas, conforme tabela, registrara-se as maiores proporções de internações masculina com AlHs de tipo 5 (tabela 26). 
Tabela 26: AlHs de tipo 5, por sexo e Regiões Metropolitanas. 2002

\begin{tabular}{lccccc}
\hline Regiăo Metropolitana & Masculina & $\%$ & Feminina & $\%$ & Total \\
\hline Núcleo da RM do N/NE de Sta & 108 & 67,5 & 52 & 32,5 & 160 \\
Catarina & 2987 & 66,2 & 1523 & 33,8 & 4510 \\
RM de Campinas & 1139 & 62,8 & 675 & 37,2 & 1814 \\
RM de Porto Alegre & 1405 & 57,3 & 1045 & 42,7 & 2450 \\
RM de Säo Luis & 1849 & 64,7 & 1011 & 35,3 & 2860 \\
RM de Maceió & 165 & 86,8 & 25 & 13,2 & 190 \\
V.do Aço-colar metrop & & & & & \\
\hline Fonte: MS/SAS/DATASUS, 2002. & & &
\end{tabular}

Para compararmos as internações, devido às diferenças no tamanho das populações estudadas, calculamos as taxas de internação para as RMs, usando a população de 15 a 49 anos e o total de AlHs para esse grupo etário. Neste primeiro momento, ainda, estão incluídas as AlHs de tipo 1 e 5, bem como as AlHs femininas com diagnóstico de Gravidez, parto e puerpério (000-099).

As maiores taxas de internação, foram registradas nas RMs de São Luis, RM de Maceió e Colar Metropolitano do Vale do Aço, regiões com IDH mais baixo (Tabela 27).

Tabela 27: Taxa de internação da população de 15 a 49, por Regiōes Metropolitanas. 2002 (por mil habitantes).

\begin{tabular}{lccc}
\hline Regióes Metropolitanas & Masculino Feminino & Total \\
\hline Núcleo da RM do N/NE de Sta Catarina & 28 & 72 & 50 \\
RM de Campinas & 36 & 70 & 53 \\
RM de Porto Alegre & 37 & 87 & 62 \\
RM de São Luís & 48 & 115 & 84 \\
RM de Maceió & 39 & 109 & 76 \\
V.do Aço - colar metropolitano & 40 & 101 & 70 \\
\hline Fonte: MS/SAS/DATASUS, 2002.
\end{tabular}

A alta taxa de internação feminina na faixa etária de 15 a 49 anos está relacionada à questão reprodutiva, pois a principal demanda das mulheres frente ao serviço hospitalar ocorre devido ao parto. As RMs de Maceió, São Luis e Colar Metropolitano do Vale do Aço apresentaram as maiores taxas devido a "Gravidez, parto e puerpério" (CapXV-CID10). Estas também são as regiões com as maiores taxas de fecundidade (Tabela 28 ). 
Tabela 28: Taxa de internação da população feminina de 15 a 49 anos, por "Gravidez, parto e puerpério" (cap 15-CID10). Região Metropolitana, 2002. (por mil mulheres)

\begin{tabular}{lc}
\hline Região Metropolitana & Taxa \\
\hline Núcleo da RM do N/NE de Sta Catarina & 44 \\
RM de Campinas & 38 \\
RM de Porto Alegre & 50 \\
RM de São Luís & 66 \\
RM de Maceió & 71 \\
V.do Aço - colar metrop & 63 \\
\hline Fonte: MS/SASIDATASUS, 2002.
\end{tabular}

Quando retiramos as internações femininas pelo diagnóstico de "Gravidez, parto e puerpério" (CapXV-CID10), verificamos que as taxas de internação se aproximam em algumas regiōes. Nas RMs de Campinas, Colar Metropolitano do Vale do Aço e Maceió, as taxas masculinas de internação superam a feminina. Nas RMs de Porto Alegre e do Núcleo do N/NE de Santa Catarina as taxas se aproximam, e na RM de Săo Luis a taxa feminina apresentou uma pequena diferença em relação à masculina (Tabela 29).

Tabela 29: Taxa de internação (AlH 1 e 5) do grupo etário de 15 a 49 (exceto capitulo 15 CID 10). Regiões Metropolitanas, 2002. (por mil habitantes)

\begin{tabular}{lcc}
\hline Regiőes Metropolitanas & \multicolumn{2}{c}{ MasculinoFeminino } \\
\hline Núcleo da RM do N/NE de Sta Catarina & 28 & 28 \\
RM de Campinas & 36 & 32 \\
RM de Porto Alegre & 37 & 37 \\
RM de Săo Luis & 48 & 49 \\
RM de Maceió & 39 & 38 \\
V.do Aço- colar metropolitano & 40 & 38 \\
\hline Fonte: MS/SAS/DATASUS, 2002. & &
\end{tabular}

Neste trabalho, além das AlHs com diagnóstico de "Gravidez, parto e puerpério" (CapXV-CID 10), também retiramos as AlHs de tipo 5.

Após esse filtro, na RM de Campinas e Porto Alegre restaram 58\% das internaçōes de 15 a 49 anos; na RM do N/NE de Santa Catarina, 55\%; 
em São Luis 53\%, no Colar Metropolitano do Vale do Aço, 52\%; e em Maceiớ, 44\% (tabela 30).

Tabela 30: AlHs de tipo $1^{*}$ de pacientes do grupo etário de 15 a 49 anos por Região Metropolitana, 2002.

\begin{tabular}{lcc}
\hline Regióes Metropolitanas & AlH & $\%$ \\
\hline Núcleo da RM do N/NE de Sta & 7589 & 55 \\
Catarina & 43632 & 58 \\
RM de Campinas & 76949 & 58 \\
RM de Porto Alegre & 29112 & 53 \\
RM de São Luís & 19591 & 44 \\
RM de Maceió & 3095 & 52 \\
V.do Aço-colar metropolitano & &
\end{tabular}

Fonte: MSISAS/DATASUS, 2002.

* Foram retiradas as AlHs com diagnóstico de Gravidez, parto e puerpério (CapXV-CID 10a Revisão)

Para esse grupo de AlHs nas RMs do N/NE de Santa Catarina e Porto Alegre as taxas de internação para homens e mulheres foram iguais; na RM de Campinas, a internação masculina foi um pouco superior à feminina e nas RMs de São Luis, Maceió e Colar Metropolitano do Vale do Aço, as taxas de internação femininas foram superiores (Tabela 31).

Tabela 31: Taxa de intemação por AlHs de tipo 1* de pacientes do grupo etário de 15 a 49 anos. Região Metropolitana, 2002 (por 1000)

\begin{tabular}{lccc}
\hline Regióes Metropolitanas & Masculino & Feminino & Total \\
\hline RM do N/NE de Sta Catarina- Núcleo & 28 & 28 & 28 \\
RM de Campinas & 32 & 30 & 31 \\
RM de Porto Alegre & 36 & 36 & 36 \\
RM de São Luís & 43 & 46 & 45 \\
RM de Maceió & 33 & 35 & 34 \\
V.do Aço-colar metropolitano & 36 & 38 & 37 \\
\hline Fonte: MS/SAS/DATASUS, 2002. & \multicolumn{4}{l}{} \\
* Foram retiradas as AlHs com diagnóstico de "Gravidez, parto e puerpério * \\
(CapXV-CID 10" Revisåo) e de tipo 5
\end{tabular}

A partir dos filtros realizados, passamos a apresentar os principais diagnóstico encontrados para o grupo de internações selecionadas. 


\section{Internação e diagnóstico}

Para a análise da morbidade hospitalar do grupo de 15 a 49 anos, usamos as taxas de internação por 100 mil habitantes, segundo o diagnóstico principal codificado de acordo com a Classificação Internacional das Doenças, 10ª revisão (CID-10).

Na RM do N/NE de Santa Catarina, conforme gráfico 5 , as principais causas de internação foram as Neoplasias (II), as Lesões e Envenenamentos (XIX), as Doenças do Aparelho Digestivo (XI), as Doenças do Aparelho Circulatório (IX) e os Transtornos Mentais e Comportamentais (V).

Gráfico 5: Taxa de internação do grupo etário de 15 a 49 anos, segundo diagnóstico (CID10). RM do N/NE de Santa Catarina (100 mil habitantes)

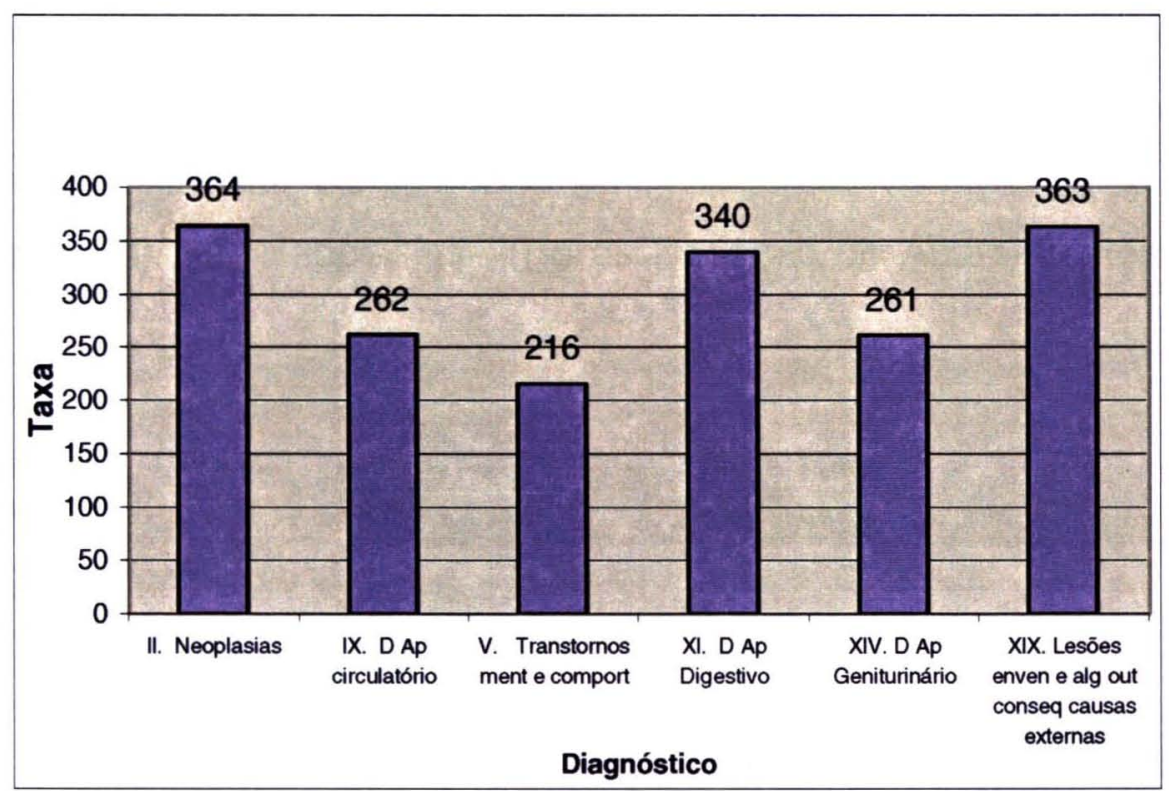

Fonte: MS/SAS/DATASUS, 2002.

Os principais diagnósticos na RM de Campinas foram as Lesões e Envenenamentos (XIX), seguido pelas Doenças do Aparelho Digestivo (XI), as Doenças do Aparelho Geniturinário (XIV), os Transtornos Mentais e Comportamentais (V), Algumas Doenças Infecciosas e Parasitárias (I) e as Neoplasias (II). 
Gráfico 6: Taxa de internação do grupo etário de 15 a 49 anos, segundo diagnóstico (CID10). RM de Campinas, 2002. (100 mil habitantes)

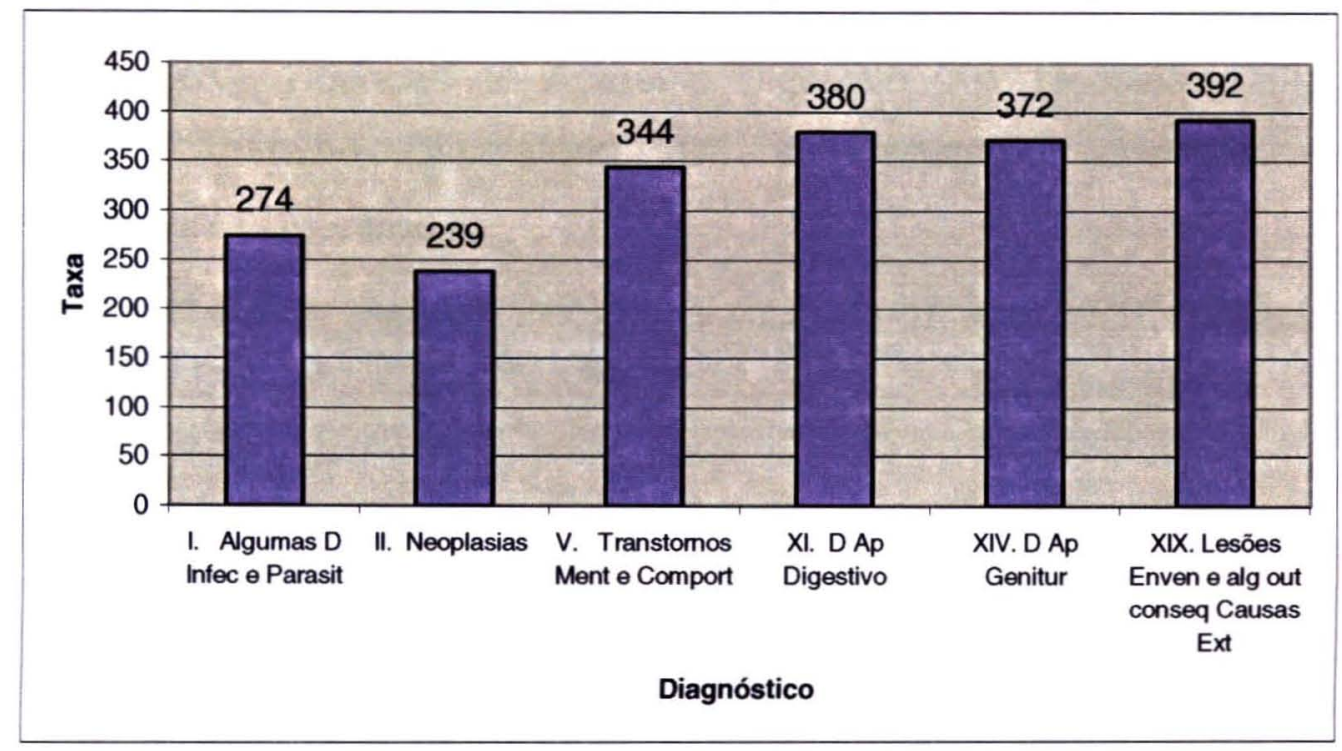

Fonte: MS/SAS/DATASUS, 2002.

$\mathrm{Na} \mathrm{RM}$ de Porto Alegre, as principais causas de internação foram as Doenças do Aparelho Digestivo (XI), as Lesões e Envenenamentos (XIX), Doenças do Aparelho Geniturinário (XIV), Algumas doenças Infecciosas e Parasitárias (I), as Neoplasias (II) e as Doenças do Aparelho Respiratório (X).

Gráfico7: Taxa de internação do grupo etário de 15 a 49 anos, segundo diagnóstico (CID 10). RM de Porto Alegre, 2002 (100 mil habitantes)

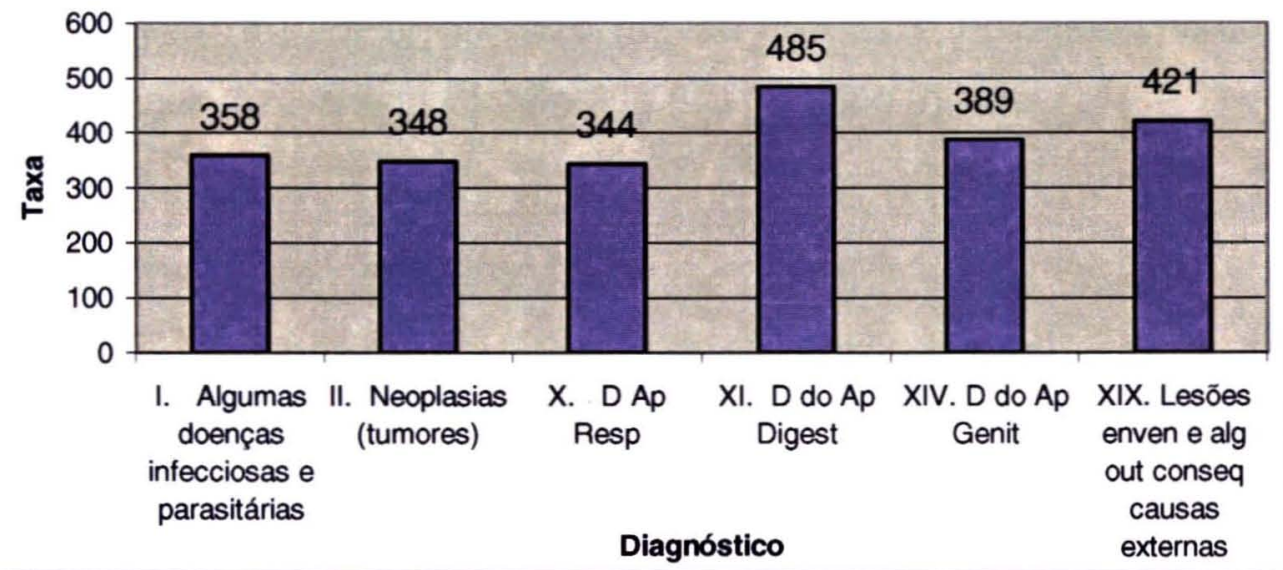

Fonte: MS/SAS/DATASUS, 2002. 
$\mathrm{Na}$ RM de São Luis, as Lesões e Envenenamentos (XIX) foram a principal causa de internação, seguida das Doenças do Aparelho Geniturinário (XIV), Doenças do Aparelho Digestivo (XI), Neoplasias (II), Doenças do Aparelho Circulatório (IX) e Transtornos Mentais e Comportamentais (V) (Gráfico 8).

Gráfico 8: Taxa de internação do grupo etário de 15 a 49 anos, segundo diagnóstico (CID10). RM de São Luis, 2002 (100 mil habitantes)

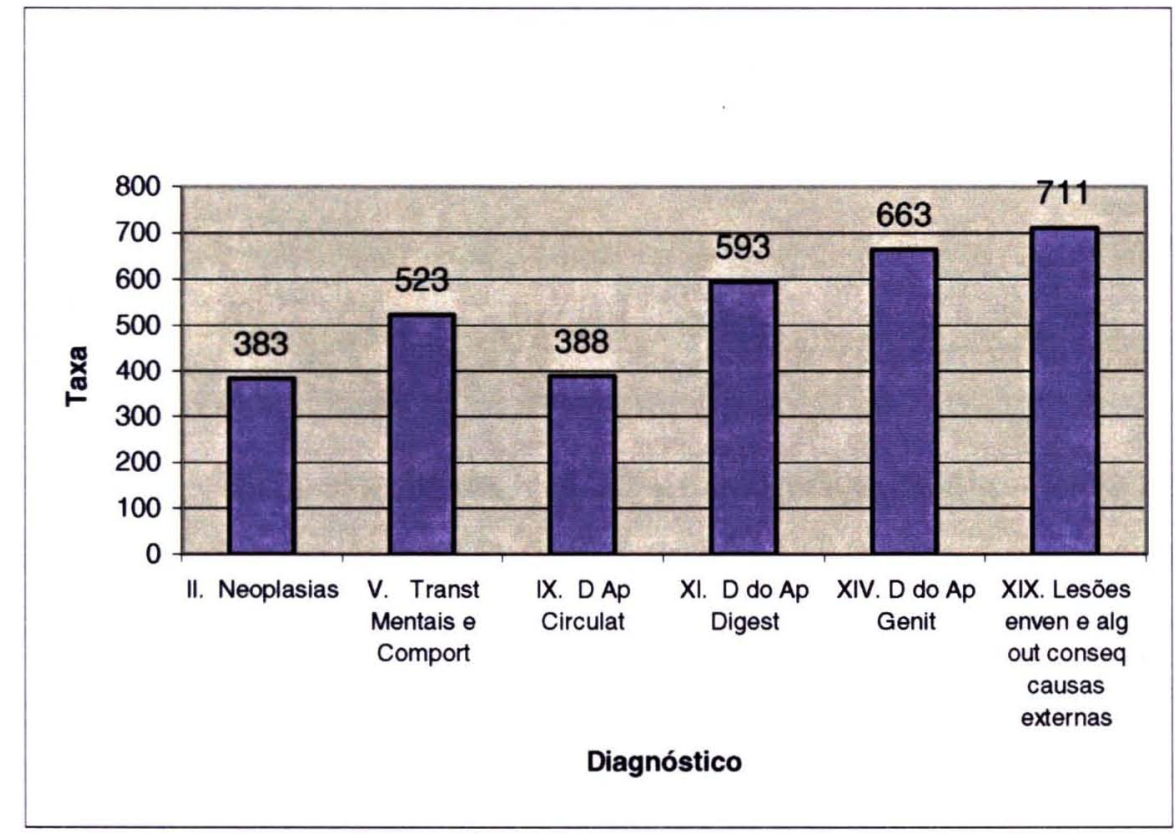

Fonte: MS/SAS/DATASUS, 2002.

$\mathrm{Na}$ RM de Maceió foram as Doenças do Aparelho Geniturinário (XIV) a principal causa de internação. Como segunda causa, verificamos os Transtornos Mentais e Comportamentais (V), seguido pelas Doenças do Aparelho Digestivo (XI), as Neoplasias (II), as Lesões e Envenenamentos (XIX) e as Doenças do Sistema Circulatório (IX) (Gráfico 9). 
Gráfico 9: Taxa de internação do grupo etário de 15 a 49 anos), segundo diagnóstico. RM de Maceió, 2002 (100 mil habitantes).

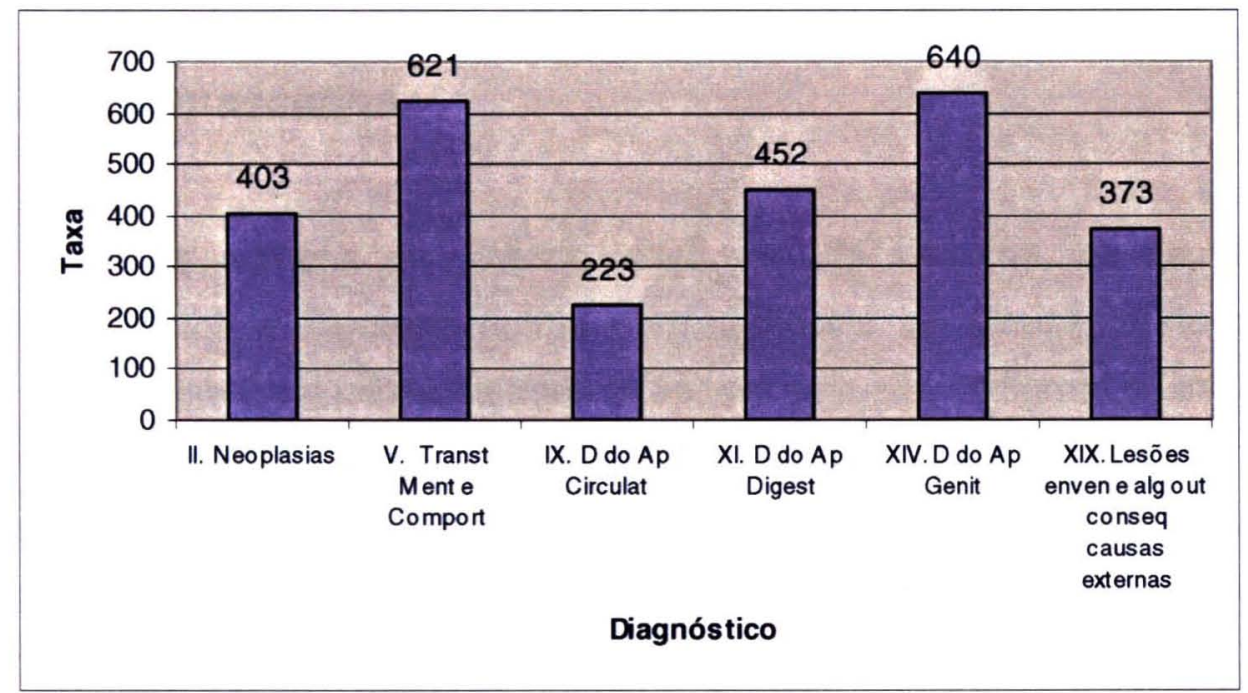

Fonte: MS/SAS/DATASUS, 2002.

No Colar Metropolitano da RM do Vale do Aço, assim como na RM de Maceió, as Doenças do Aparelho Geniturinário (XIV) foram a principal causa de internação, seguindo, conforme Gráfico 10, as Doenças do Aparelho Digestivo (XI), as Lesões e Envenenamentos (XIX), as Doenças do Aparelho Circulatório (IX), as Doenças do Aparelho Respiratório (X) e Algumas Infecciosas e Parasitárias (I).

Gráfico 10: Taxa de internação do grupo etário de 15 a 49 anos, segundo diagnóstico. RM do Vale do Aço- Colar, 2002. (100 mil habitantes)

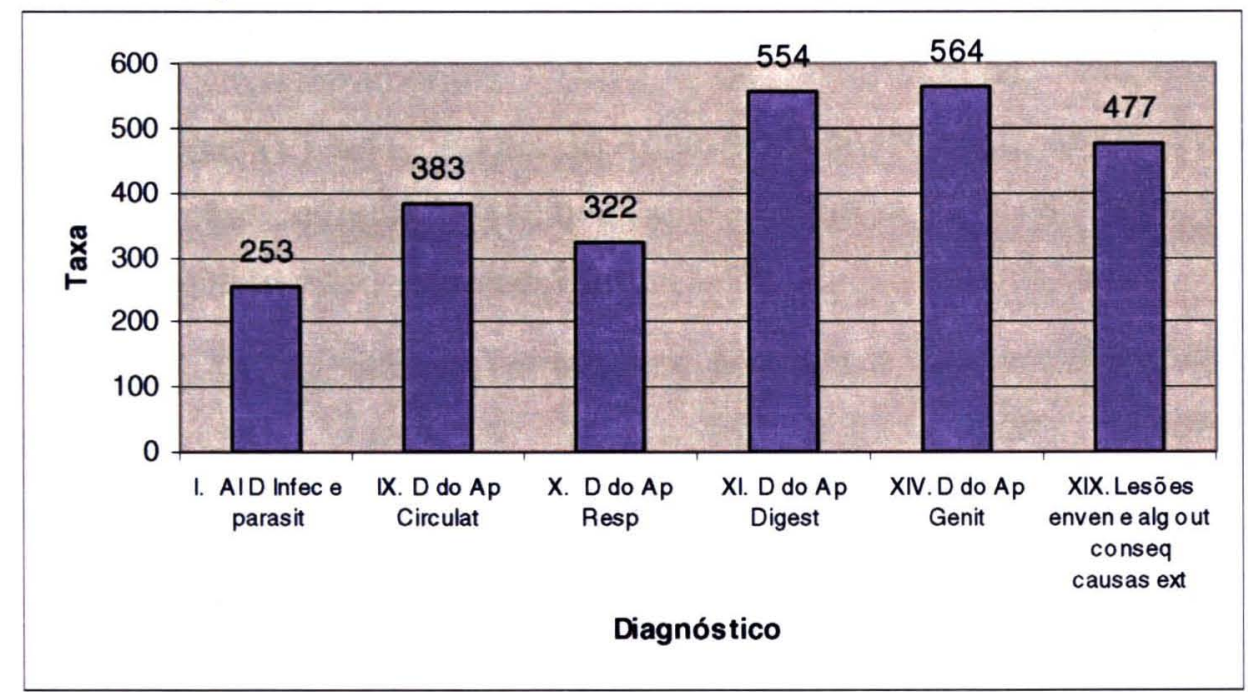

Fonte: MS/SAS/DATASUS, 2002. 
As Lesões e Envenenamentos (XIX), juntamente com as Doenças do Aparelho Digestivo (XI) e as Doenças do Aparelho Geniturinário (XIV), foram os diagnósticos presentes em todas as RMs.

\section{Morbidade masculina}

Para os homens da RM do N/NE de Sta Catarina, as Lesões, Envenenamentos e algumas outras conseqüências de Causas Externas (XIX) foram a principal causa de internação, em seguida, conforme o Gráfico 11, estão as Doenças do Aparelho Digestivo (XI), os Transtornos Mentais e Comportamentais (V), as Neoplasias (II), Algumas Doenças Infecciosas e Parasitárias (I) e Doenças do Aparelho Respiratório (X).

Na RM de Campinas, além das Lesões e Envenenamentos (XIX), observamos, ainda, os Transtornos Mentais e Comportamentais ( $V$ ), as Doenças do Aparelho Digestivo (XI), Algumas Doenças Infecciosas e Parasitárias (I), Doenças do Aparelho Circulatório e Respiratório (X) (gráfico 11).

Para a RM de Porto Alegre destacam-se como principal causa de internação as Lesões e Envenenamentos (XIX), seguida pelas Doenças do Aparelho Digestivo $(\mathrm{XI})$, as Doenças do Aparelho Respiratório $(\mathrm{X})$, as Infecciosas (I), as Doenças do Aparelho Circulatório (IX) e os Transtornos Mentais e Comportamentais (V) (Gráfico 11).

Em São Luis, as principais causas de internação masculina foram as Lesões e Envenenamentos (XIX), os Transtornos Mentais e Comportamentais $(\mathrm{V})$, as Doenças do Aparelho Digestivo (XI), as Neoplasias (II), as Algumas Doenças Infecciosas e Parasitárias (I) e as Doenças do Aparelho Circulatório (IX) (Gráfico 11).

Na RM de Maceió os Transtornos Mentais e Comportamentais (V) foram a principal causa de internação, seguida pelas Lesões e Envenenamentos $(X \mid X)$, Doenças do Aparelho Digestivo $(X I)$, Doenças do 
Aparelho Circulatório, Algumas Doenças Infecciosas e Parasitárias (I) e Doenças do Aparelho Respiratório (X) (Gráfico 11).

Por fim, no Colar da RM do Vale do Aço, as principais causas de internação masculina foram as Lesões e Envenenamentos (XIX), as Doenças do Aparelho Digestivo (XI), Circulatório (IX), Respiratório (X), Geniturinário (XIV) e Algumas Doenças Infecciosas e Parasitárias (I) (Gráfico 11).

Para a populaçăo masculina, não encontramos um padrão de morbidade único para todas as RMs. A única semelhança observada foram as Lesões, Envenenamentos e algumas outras conseqüências de causas externas, que aparecem como o principal diagnóstico de internação em quase todas as RMs, exceto em Maceió, onde foram os Transtornos Mentais e Comportamentais, diagnóstico que também aparece como motivo de internação para os homens de N/NE de Sta Catarina, Campinas, Porto Alegre e Săo Luis. Além desses dois diagnósticos, conforme Gráfico 11, ocorreram internaçōes por Neoplasias, Doenças do Aparelho Digestivo, Circulatório, Respiratório e Algumas Infecciosas e Parasitárias. 
Gráfico 11: Taxas de internação do grupo etário de 15 a 49 anos, segundo diagnóstico (por 100 mil homens). Regiões Metropolitanas, 2002.

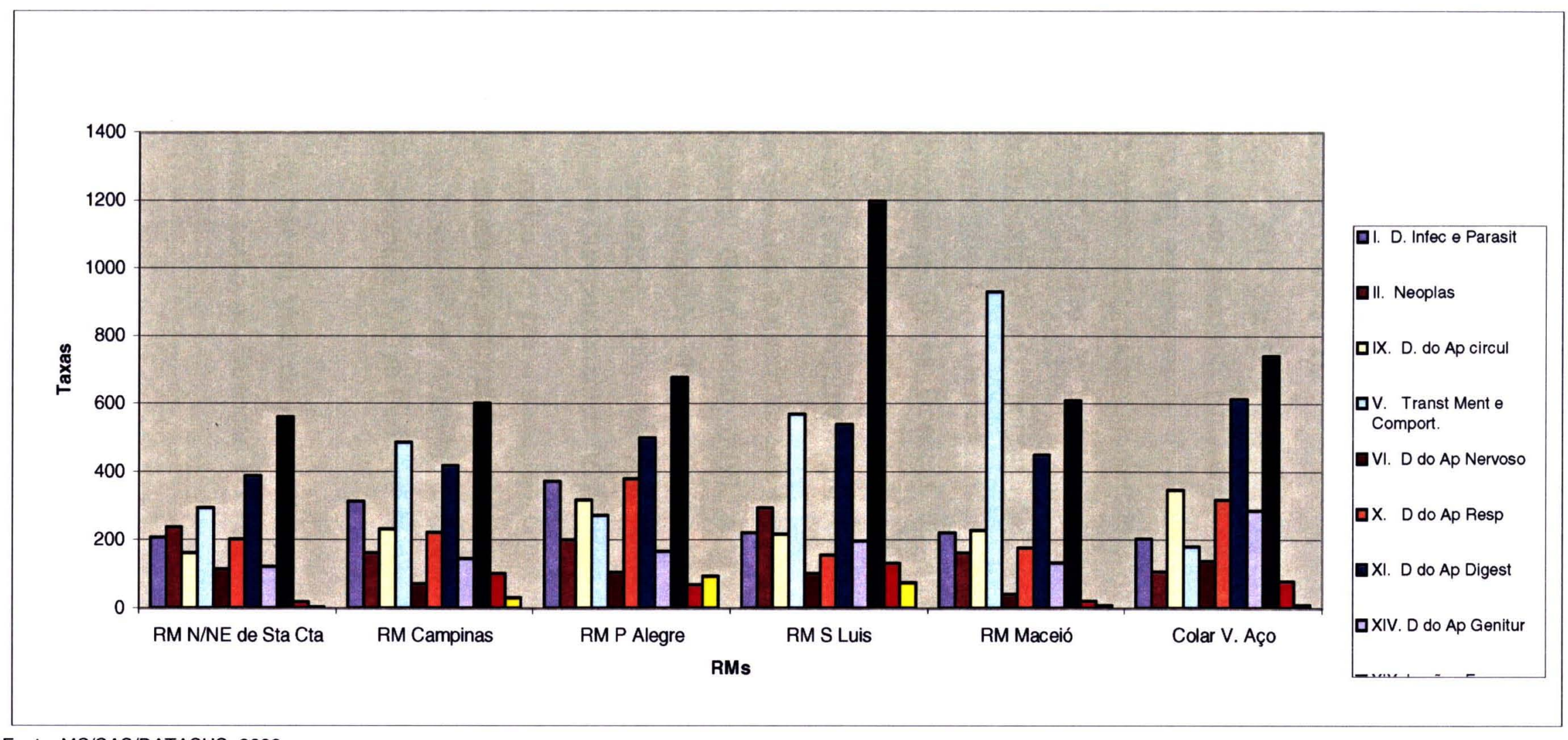

Fonte: MS/SAS/DATASUS, 2002. 


\section{Morbidade Feminina}

No N/Ne de Sta Catarina além das Neoplasias (I), as principais taxas de internação encontrada para o grupo de mulheres de 15 a 49 anos dessa região, foram as Doenças do Aparelho Geniturinário (XIV), Circulatório (IX), Digestivo (XI), Algumas Infecciosas e Parasitárias (I) e, por fim, Lesões e Envenenamentos (XIX) (Gráfico 12).

Em Campinas, além das Doenças do Aparelho Geniturinário (XIV), encontramos ainda como principais causas de internação, as Doenças do Aparelho Digestivo (XI), as Neoplasias (II), Algumas Doenças Infecciosas e Parasitárias (I), Doenças do Aparelho Circulatório (IX) e Transtornos Mentais e Comportamentais $(N)$ (Gráfico 12).

Para a RM de Porto Alegre, o principal diagnóstico foram as Doenças do Aparelho Geniturinário (XIV).Destacaram-se também como causa de internação, as Neoplasias (I), as Doenças do Aparelho Digestivo (XI), Algumas Doenças Infecciosas e Parasitárias (I), Doenças do Aparelho Circulatório (IX) e do Aparelho Respiratório (X) (Gráfico 12).

Nas RM de Săo Luis, a maior taxa de internação foi observada pelas Doenças do Sistema Geniturinário (XIV). Como segunda causa de internação, estão as Neoplasias (II), seguidas pelas Doenças do Aparelho Digestivo (XI), Circulatório (IX), Lesões, Envenenamentos (XIX) e Transtornos Mentais e Comportamentais (V) (Gráfico 12).

Conforme Gráfico 12, em Maceió, as Geniturinárias (XIV) também foram a principal causa de internação feminina. Em seguida, estão as Neoplasias (II), as Doenças do Aparelho Digestivo (XI), os Transtornos Mentais e Comportamentais (V), as Doenças do Aparelho Circulatório (IX) e as Lesões (XIX).

No Colar da RM do Vale do Aço, entre as 6 principais causas de internação femininas estão as Doenças do Aparelho Geniturinário (XIV), 
Aparelho Digestivo (XI), Circulatório (IX), as Neoplasias (II), as Doenças do Aparelho Respiratório (X) e Algumas Doenças Infecciosas e Parasitárias (I).

Enquanto para a populaçăo masculina as Lesões e Envenenamentos foram a principal causa de internação, para as mulheres -com exceção do N/NE de Sta Catarina, onde foram as neoplasias- nas demais regiőes, foram as Doenças do Aparelho Geniturinário o principal motivo de internaçăo feminina. Nas RMs com menor IDH, chama a atenção as altíssimas taxas de internaçăo por essa causa, ainda que essa se destaque entre as principais causas também nas regiōes com IDH mais alto.

Nas com menor IDH a diferença entre essa causa e as demais é bem maior (Gráfico 12). Entre os 6 principais diagnóstico para mulheres, além das Doenças do Aparelho Geniturinário, estão ainda as Neoplasias, as Doenças do Aparelho Digestivo e do Aparelho Respiratório, que são os mais freqüentes em todas as Regiões Metropolitanas. 
Gráfico 12: Taxa de internação para o grupo etário de 15 a 49 anos), segundo diagnóstico (por 100 mil mulheres). Regiões Metropolitanas, 2002

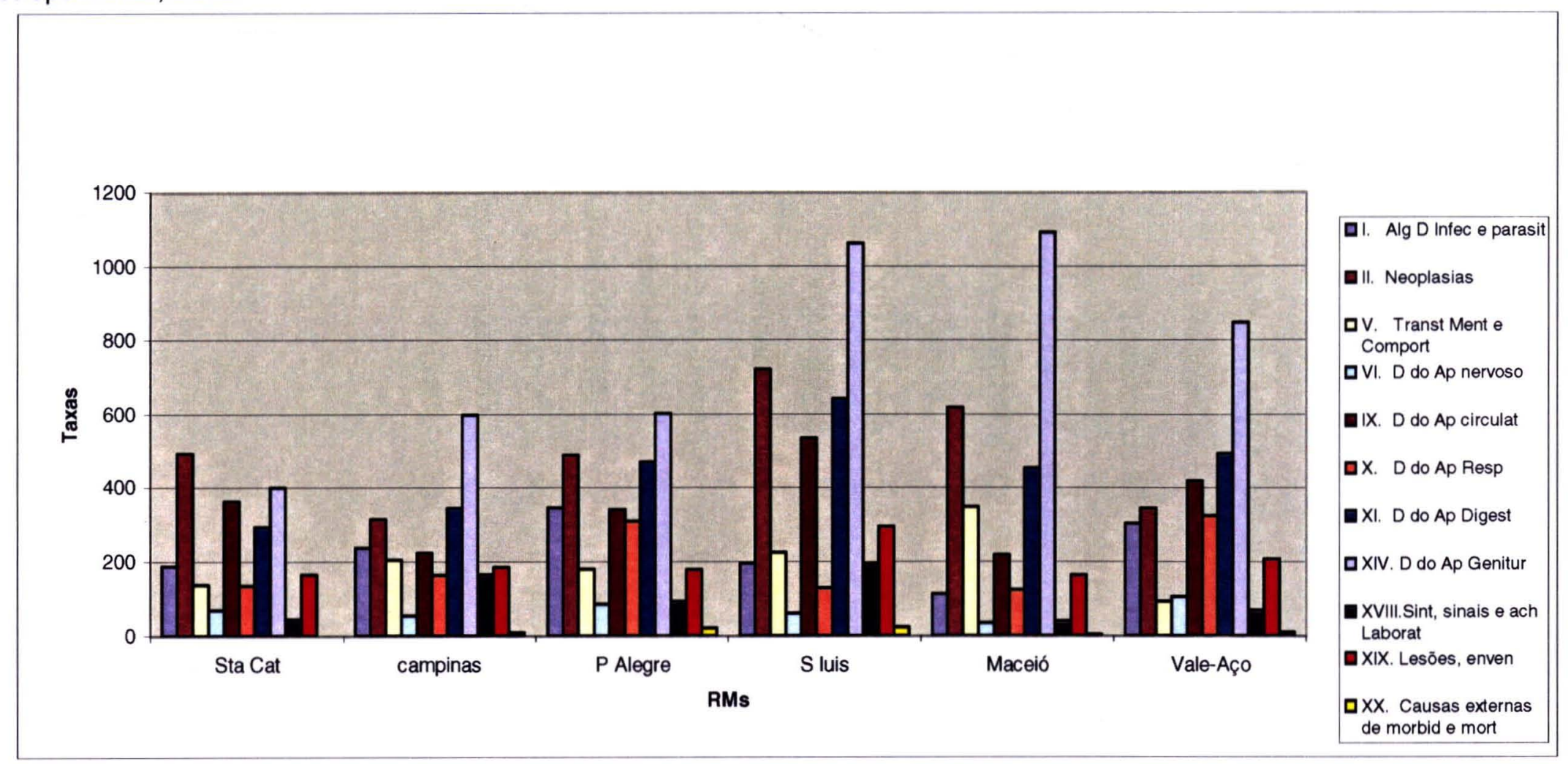

Fonte: MS/SAS/DATASUS, 2002. 
Comparando o perfil de morbidade masculina e feminina nas Regiōes Metropolitanas

Com base na apresentaçăo anterior, identificamos as principais causas de diagnóstico para os homens e mulheres, fizemos um recorte para comparar o perfil da morbidade masculina e feminina nas seis RMs. As causas selecionadas são:

I. Algumas Doenças Infecciosas e Parasitárias;

II. Neoplasias;

V. Transtornos Mentais e Comportamentais;

IX. Doenças do Sistema Circulatório;

X. Doenças do Aparelho Respiratório;

XI. Doenças do Sistema Digestivo;

XIV. Doenças do Sistema Geniturinário;

XIX. Lesões, Envenenamentos e algumas outras conseqüências de Causas Externas.

Para verificar se as diferenças nas taxas de morbidade de homens e mulheres eram estatisticamente significantes, utilizamos 0 Teste de Proporçăo para duas amostras.

A seguir apresentamos a comparaçăo das taxas masculinas e femininas para os diagnósticos selecionados. 
Tabela 32 Taxa de internação para o grupo etário de 15 a 49 anos, segundo diagnóstico (CID10). Regiões Metropolitanas, 2002. (Por 100 mil homens ou mulheres)

\begin{tabular}{|c|c|c|c|c|c|c|c|c|c|}
\hline \multirow{2}{*}{ Diagnóstico CID10 } & \multicolumn{3}{|c|}{ N/NE de Sta Cat } & \multicolumn{3}{|c|}{ Campinas } & \multicolumn{3}{|c|}{ P Alegre } \\
\hline & Masc. & Fem. & Valor-p & Masc. & Fem. & Valor-p & Masc. & Fem. & Valor-p \\
\hline I. Algumas doenças infecciosas $\theta$ parasitárias & 207 & 187 & 0,243 & 313 & 236 & 0,000 & 371 & 346 & 0,002 \\
\hline II. Neoplasias (tumores) & 237 & 491 & 0,000 & 162 & 314 & 0,000 & 200 & 489 & 0 \\
\hline V. Transtornos mentais e comportamentais & 294 & 137 & 0,000 & 485 & 206 & 0,000 & 272 & 181 & 0 \\
\hline IX. Doenças do Aparelho Circulatório & 162 & 362 & 0,000 & 232 & 223 & 0,233 & 317 & 341 & 0,002 \\
\hline X. Doenças do Aparelho Respiratório & 202 & 136 & 0,000 & 222 & 164 & 0,000 & 380 & 310 & 0 \\
\hline XI. Doenças do Aparelho Digestivo & 386 & 293 & 0,000 & 416 & 345 & 0,000 & 500 & 470 & 0,002 \\
\hline XIV. Doenças do Aparelho Geniturinário & 121 & 401 & 0,000 & 144 & 597 & 0,000 & 166 & 601 & 0 \\
\hline XIX. Lesões enven e alg out conseq causas externas & 560 & 166 & 0,000 & 602 & 186 & 0,000 & 677 & 178 & 0 \\
\hline Total & 2751 & 2760 & 0,884 & 3196 & 2982 & 0,000 & 3603 & 3596 & 0,783 \\
\hline
\end{tabular}

Fonte: MS/SAS/DATASUS, 2002. 
Tabela 32 Taxa de internação para o grupo etário de 15 a 49 anos, segundo diagnóstico (CID10). Regiões Metropolitanas, 2002. (Por 100 mil homens ou mulheres)

\begin{tabular}{l|ccc|ccc|cc|cc}
\hline & \multicolumn{3}{c|}{ S Luis } & \multicolumn{3}{c|}{ Maceió } & \multicolumn{3}{c}{ Vale do Aço-Colar } \\
\cline { 2 - 10 } \multicolumn{1}{c}{ Diagnóstico CID10 } & Masc. & Fem. & Valor-p & Masc. & Fem. Valor-p & Masc. & Fem. Valor-p \\
\hline I. Algumas doenças infecciosas e parasitárias & 221 & 196 & 0,026 & 221 & 112 & 0,000 & 203 & 303 & 0,004 \\
II. Neoplasias (tumores) & 294 & 720 & 0,000 & 161 & 618 & 0,000 & 106 & 344 & 0 \\
V. Transtornos mentais e comportamentais & 568 & 225 & 0,000 & 930 & 347 & 0,000 & 179 & 92 & 0,001 \\
IX. Doenças do Aparelho Circulatório & 216 & 534 & 0,000 & 228 & 218 & 0,422 & 347 & 419 & 0,09 \\
X. Doenças do aparelho Respiratório & 155 & 129 & 0,004 & 177 & 124 & 0,000 & 318 & 325 & 0,863 \\
XI. Doenças do Aparelho Digestivo & 538 & 641 & 0,000 & 449 & 454 & 0,811 & 613 & 494 & 0,02 \\
XIV. Doenças do Aparelho Geniturinário & 196 & 1063 & 0,000 & 133 & 1092 & 0,000 & 285 & 848 & 0 \\
XIX. Lesões enven e alg out conseq causas externas & 1196 & 295 & 0,000 & 608 & 164 & 0,000 & 741 & 207 & 0 \\
\hline Total & 4350 & 4607 & 0,000 & 3254 & 3497 & 0,000 & 3625 & 3752 & 0,328 \\
\hline
\end{tabular}

Fonte: MS/SAS/DATASUS, 2002. 


\section{Algumas doenças infecciosas e parasitárias}

Para as taxas de internação por doenças infecciosas e parasitárias por 100 mil habitantes, no grupo de 15 a 49 anos, observamos que a RM de Porto Alegre foi a que apresentou a maior taxa de internação, seguida pela RM de Campinas, Colar Metropolitano do Vale do Aço, São Luis, o N/NE de Sta Catarina e Maceió (Gráfico 13).

Gráfico 13: Taxas de internação para o grupo etário de 15 a 49 anos, por Algumas Doenças Infecciosas e Parasitárias. Regiões Metropolitanas, 2002 (100.000 habitantes)

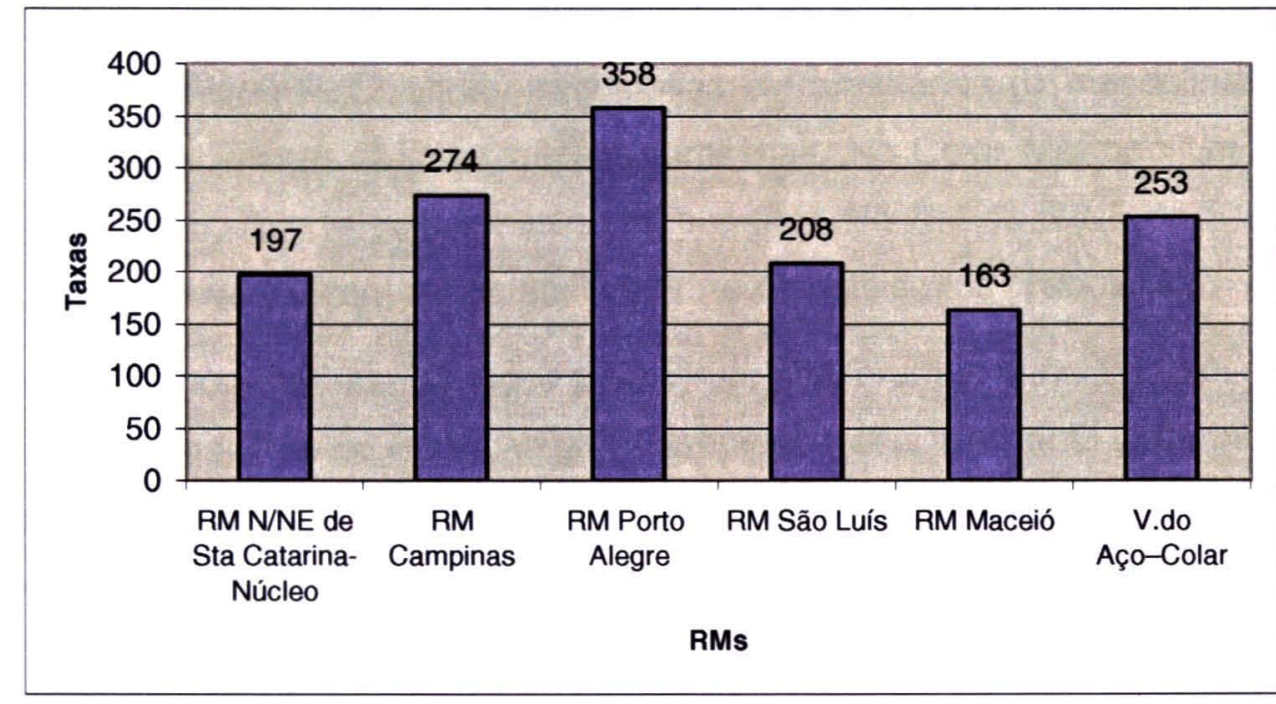

Fonte: MS/SAS/DATASUS, 2002.

$\mathrm{Na}$ análise da taxa geral não observamos um padrão no qual pudéssemos afirmar que as regiões com melhor IDH representassem um perfil e aquelas com pior IDH outro. Porém, quando desagregamos a categoria de Infecciosas e Parasitarias, observamos dois perfis distintos para o grupo de 15 a 49 anos. As doenças pelo HIV aparecem como principal causa de internação nas RMs do N/NE de Santa Catarina, Campinas e Porto Alegre, enquanto as Doenças Infecciosas Intestinais são o principal motivo nas RMs de São Luis, Maceió e o Colar Metropolitano do Vale do Aço (Tabela 33). 
Tabela 33: Taxa de intemação de homens e mulheres do grupo etário de 15 a 49 anos, por Doença pelo vírus da imunodeficiência humana (HIV), Doenças Infecciosas Intestinais e Hanseniase. Regiões Metropolitanas, 2002. (por 100.000 habitantes, homens e mulheres)

\begin{tabular}{l|ccc|ccc|ccc}
\hline \multirow{2}{*}{ Regióes Metropolitanas } & \multicolumn{4}{c}{ D pelo HIV } & \multicolumn{4}{c}{ D infec intest } & Hanseniase \\
\cline { 2 - 10 } & M & F & T & M & F & T & M & F & T \\
\hline RM N/NE de Sta Catarina- Núcleo & 104 & 34 & 69 & 29 & 36 & 32 & 0,7 & 0 & 0,4 \\
RM Campinas & 146 & 82 & 114 & 15 & 11 & 13 & 0,6 & 0,4 & 0,5 \\
RM Porto Alegre & 175 & 93 & 133 & 52 & 45 & 48 & 0,1 & 0,2 & 0,1 \\
RM Såo Luis & 38 & 14 & 25 & 59 & 54 & 57 & 43 & 12 & 26 \\
RM Maceió & 46 & 18 & 31 & 43 & 28 & 35 & 3 & 0 & 1 \\
V.do Aço-Colar & 5 & 7 & 6 & 64 & 58 & 61 & 5 & 0 & 2 \\
\hline
\end{tabular}

Fonte: MS/SAS/DATASUS, 2002.

Nas RM de Porto Alegre, Campinas, Maceió e São Luis, as taxas de internação por Algumas Doenças Infecciosas e Parasitárias (I) masculinas foram significativamente maiores que as femininas. No Colar Metropolitano da RM do Vale do Aço, a taxa feminina foi superior. Na RM do N/NE de Sta Catarina não houve diferença significativa entre os dois sexos (Tabela 32).

Para os homens, as Doenças pelo vírus HIV foram a principal causa de internação nas RMs de Porto Alegre, Campinas, N/NE de Santa Catarina e Maceió. No Colar Metropolitano do Vale do Aço foram as Doenças Infecciosas Intestinais. Na RM de São Luis foram as doenças bacterianas (63/100.000 habitantes). Interessante ressaltar que neste grupo está a hanseniase, enfermidade que apresentou uma taxa de internação de 43/100 mil para os homens e 12/100 mil para as mulheres (Tabela 33).

A RM de São Luis foi a que apresentou a maior taxa de internação por hanseníase, enquanto que na RM de Porto Alegre, encontramos a menor taxa. Exceto por essa última região, nas demais RMs, a taxa de internação masculina por hanseniase foi superior à feminina (Tabela 33). 
Tabela 34: Taxa de internação do grupo etário de 15 a 49 anos. por Infecções de transmissão predominantemente sexual e tuberculose, segundo sexo. Regiōes Metropolitanas, 2002. (por 100.000)

\begin{tabular}{l|ccc|ccc}
\hline Regióes Metropolitanas & \multicolumn{3}{|c|}{ Infec de trans pred } & \multicolumn{3}{|c}{ Tuberculose } \\
\cline { 2 - 7 } & $\mathbf{M}$ & $\mathbf{F}$ & $\mathbf{T}$ & $\mathbf{M}$ & $\mathbf{F}$ & $\mathbf{T}$ \\
\cline { 2 - 7 } RM N/NE de Sta Catarina- Núcleo & $\mathbf{0}$ & 76 & 38 & 12 & 4 & 8 \\
RM Campinas & 3 & 76 & 40 & 50 & 10 & 30 \\
RM Porto Alegre & 1 & 126 & 65 & 30 & 12 & 21 \\
RM Săo Luis & 0 & 64 & 35 & 19 & 11 & 15 \\
RM Maceión & 1 & 2 & 2 & 24 & 8 & 15 \\
V.do Aço-Colar & 2 & 82 & 42 & 17 & 7 & 12 \\
\hline
\end{tabular}

Fonte: MS/SAS/DATASUS, 2002.

Nas RMs de Porto Alegre, N/NE de Sta Catarina, no Colar Metropolitano do Vale do Aço e São Luis, para as mulheres, a principal causa de internação entre as Doenças Infecciosas e Parasitarias (I) foram as Infecções de Transmissão predominantemente Sexual. Na RM de Campinas foram as Doenças pelo HIV e na RM de Maceió as Doenças Infecciosas Intestinais. (tabelas 33 e 34 )

A Tuberculose também aparece como uma das principais taxas de internação nas RMs estudadas, principalmente para os homens que apresentam as maiores taxas (Tabela 34).

\section{As Neoplasias}

A maior taxa de internação por Neoplasias (I) foi encontrada na RM de São Luis, seguida da RM de Porto Alegre, N/NE de Sta Catarina, Maceió, Campinas e Colar Metropolitano do Vale do Aço (Gráfico14). 
Gráfico 14: Taxas de internação para o grupo etário de 15 a 49 anos por Neoplasias (I). Regiões Metropolitanas, 2002 (100000 habitantes)

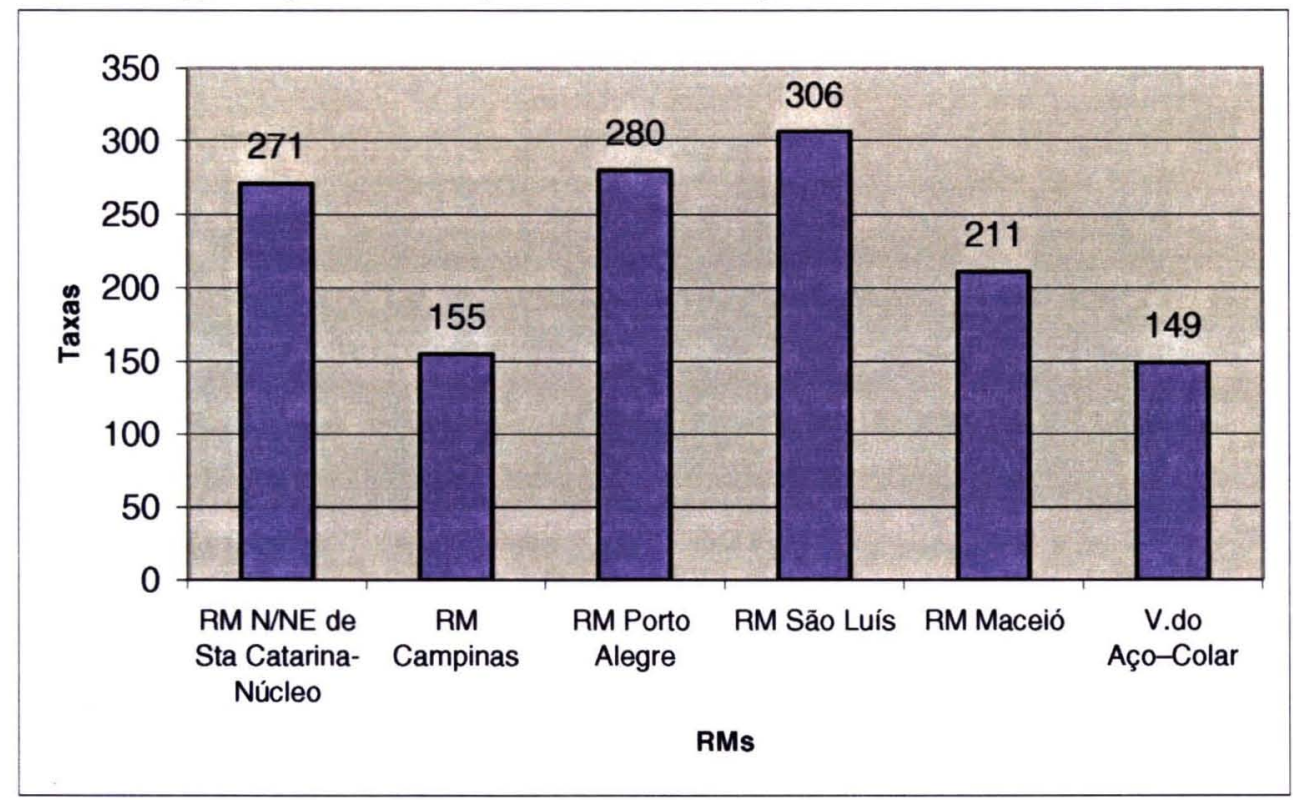

Fonte: MS/SAS/DATASUS, 2002.

Em todas as RMs, as mulheres apresentaram taxas significativamente maiores que os homens para o total de Neoplasias (I). A RM de São Luis, é a região com maior taxa, seguida por Maceió, N/NE de Sta Catarina, Porto Alegre, Colar Metropolitano do Vale do Aço e Campinas (Tabela 32).

No grupo de Neoplasias, as malignas são as que apresentam as principais taxas de internação. Nesta categoria para as mulheres, as Neoplasias Malignas dos Órgãos Genitais femininos foram a principal causa de internação. A RM de São Luis aparece novamente com a maior taxa: 277 por 100 mil mulheres. A seguir encontramos as RMs do N/NE de Sta Catarina, Porto Alegre, Colar Metropolitano do Vale do Aço, Maceió e Campinas, conforme se pode observar no Gráfico 15 , no qual comparamos as taxas de internação por neoplasias dos órgãos genitais e mama. 
Gráfico 15: Taxa de internação de mulheres do grupo etário de 15 a 49 anos, por Neoplasias Malignas dor Órgão genitais Femininos e Mama. Regiões Metropolitanas, 2002.

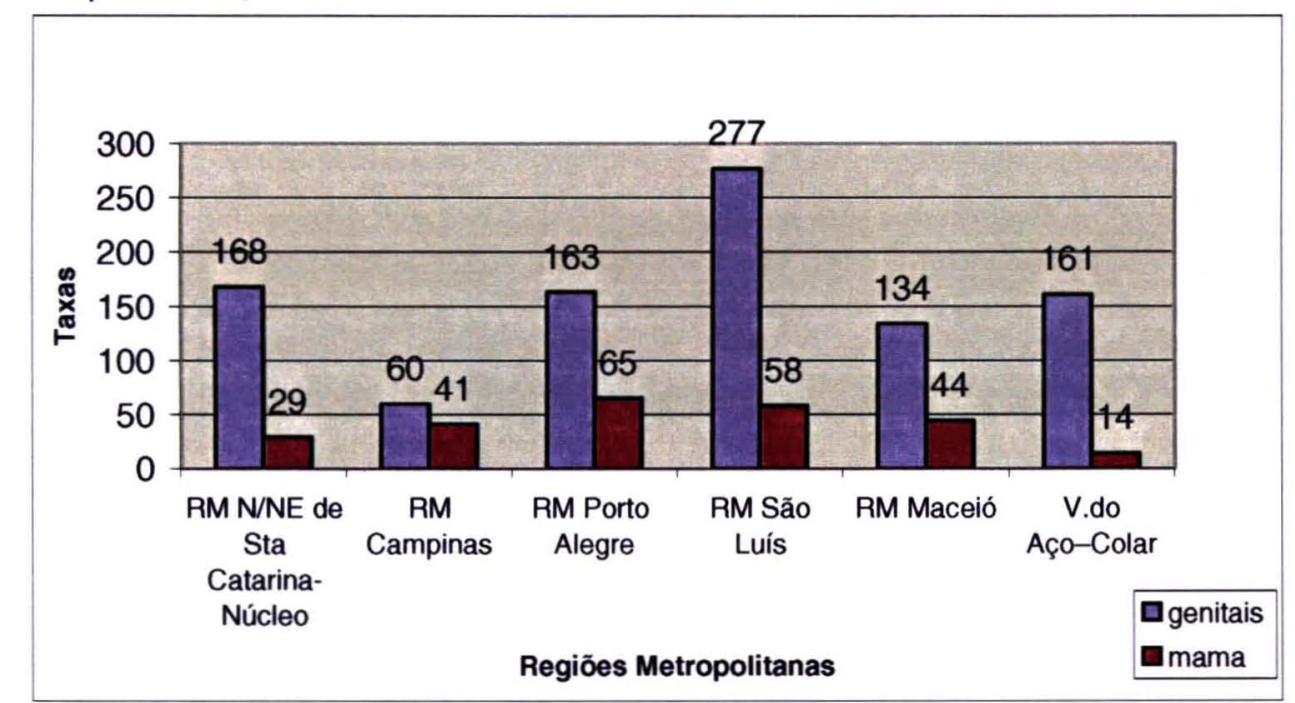

Fonte: MS/SAS/DATASUS, 2002.

As Neoplasias Malignas dos Órgãos Digestivos aparecem como a principal causa de internação para os homens. Entre as RMs estudadas, Campinas aparece com a maior taxa (45/100.000 homens), seguida por Porto Alegre (44/100.000 homens), N/NE de Sta Catarina (40/100.000 homens), São Luis (31/100.000 homens) e o Colar (26/100.000 homens). Na RM de Maceió a principal causa de internação foram os Melanomas e outras Neoplasias Malignas de Pele, com uma taxa de 23 por 100.000 homens de 15 a 49 anos.

\section{Transtornos mentais e comportamentais}

Para o total de internações do grupo etário de 15 a 49 anos, a RM de Maceió foi onde encontramos a maior taxa de internação pelos transtornos mentais, 621 por 100 mil habitantes, seguida pelas RMs de São Luis, Campinas, Porto Alegre, N/NE de Sta Catarina e o Colar Metropolitano do Vale do Aço (Gráfico 16). 
Gráfico 16: Taxas de internação para o grupo etário de 15 a 49 anos, por Transtornos Mentais e Comportamentais (V). Regiões Metropolitanas, 2002 (100000 habitantes)

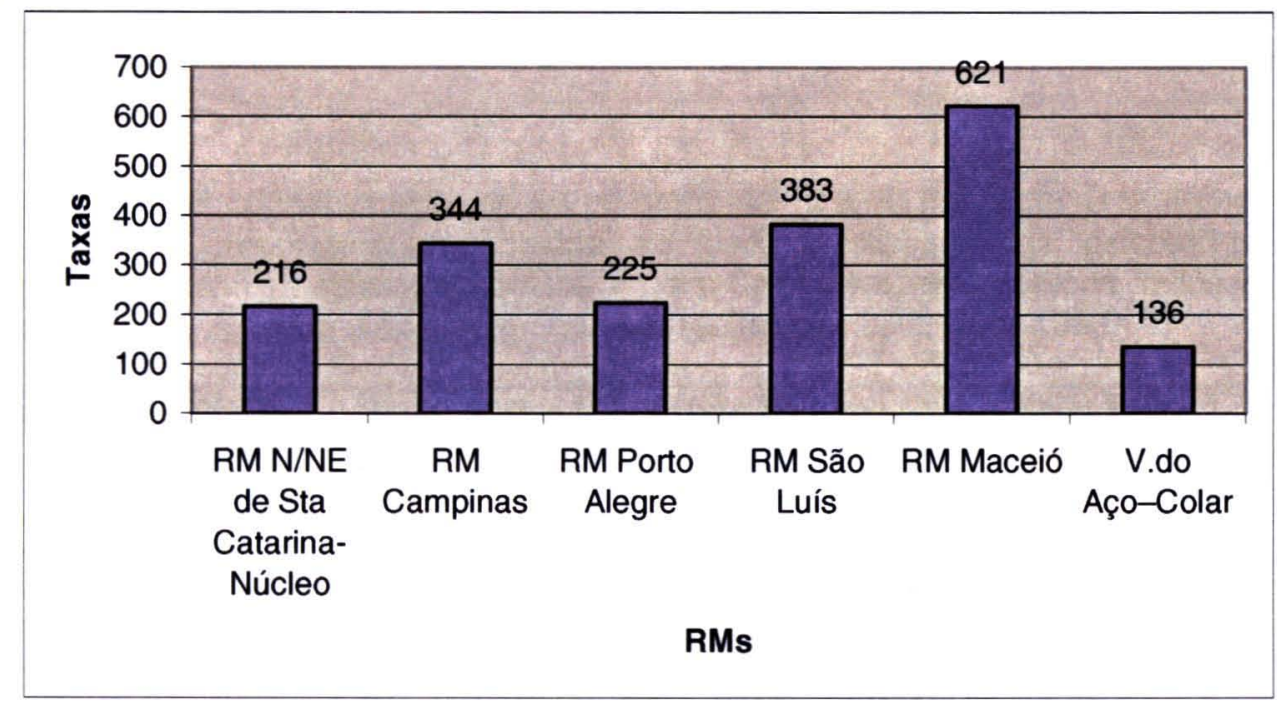

Fonte: MS/SAS/DATASUS, 2002.

Enquanto as taxas de internação por Neoplasias em todas as regiões foram significativamente superiores para as mulheres, no caso dos Transtornos Mentais e Comportamentais ${ }^{6}$ a situação se inverte: as taxas de internação masculina são superiores em todas as RMs (Tabela 32).

Para os homens, a RM de Maceió apresentou a maior taxa de internação; em seguida estão as RMs de São Luis, Campinas, N/NE de Sta Catarina, Porto Alegre e Colar Metropolitano do Vale do Aço. A taxa de internação de Maceió, de 930 por 100 mil homens, foi $242 \%$ superior a taxa de Porto Alegre, com 272/ 100.000 homens (Tabela 32).

Para as mulheres, a maior taxa encontrada também foi na RM de Maceió, porém com valor bem inferior à masculina, enquanto que no Colar Metropolitano do Vale do Aço, RM que apresentou a menor taxa, foi também onde encontramos a menor diferença entre os sexos (Tabela 32).

Tentando identificar, qual o principal motivo de internação por essa categoria, verificamos que nas RMs de Campinas, N/NE de Sta Catarina e

\footnotetext{
${ }^{6}$ Para o cálculo das taxas de internação por Transtornos Mentais, utilizamos somente as AlHs 1. Toda internação inicia-se com uma AlH desse tipo, somente após o prazo de 107 dias, nos casos de internações de longa permanência, é aberta uma AlH de tipo 5.
} 
Porto Alegre as maiores taxas foram pelos transtornos provocados por substâncias psicoativas, que inclui o álcool, porém, apesar de aparecerem como segunda principal causa de internação nas RMs de Maceió e São Luis, as taxas nestas duas RMs são superiores às das RMs anteriores (Tabela 35).

Tabela 35: Taxa de internaçăo do grupo etário de 15 a 49 anos, por Transtornos Mentais e Comportamentais devido ao uso de substancias psicoativas, Esquizofrenias, Transtomos Esquizotipicos e Delirantes, e Orgânicos inclusive sintomáticos, segundo sexo. Regiő́es Metropolitanas, 2002. (por 100.000)

\begin{tabular}{|c|c|c|c|c|c|c|c|c|c|}
\hline \multirow[t]{2}{*}{ Rogloes Motropolitanes } & \multicolumn{3}{|c|}{$\begin{array}{l}\text { Weo de Subet } \\
\text { polcontiva }\end{array}$} & \multicolumn{3}{|c|}{$\begin{array}{c}\text { Esquizotronins, transt } \\
\text { equizotipicos } \\
\text { dellrantes }\end{array}$} & \multicolumn{3}{|c|}{$\begin{array}{l}\text { Organicos Inclustve } \\
\text { sintomiticos }\end{array}$} \\
\hline & $\mathbf{M}$ & $F$ & $\mathbf{T}$ & $\mathbf{M}$ & $\mathbf{F}$ & $\mathbf{T}$ & $\mathbf{M}$ & $F$ & $\mathbf{T}$ \\
\hline $\begin{array}{l}\text { RM N/NE de Sta Catarina- } \\
\text { Núcleo }\end{array}$ & 146 & 23 & 84 & 15 & 6 & 10 & 74 & 58 & 66 \\
\hline RM Campinas & 254 & 25 & 139 & 147 & 69 & 108 & 24 & 16 & 20 \\
\hline RM Porto Alegre & 121 & 22 & 70 & 75 & 42 & 58 & 17 & 13 & 15 \\
\hline RM Săo Luis & 235 & 19 & 119 & 125 & 116 & 175 & 11 & 3 & 7 \\
\hline RM Maceio & 350 & 17 & 174 & 420 & 233 & 321 & 79 & 24 & 50 \\
\hline V.do Aço-Colar & 40 & 7 & 24 & 97 & 51 & 74 & 21 & 0 & 11 \\
\hline
\end{tabular}

Fonte: MSISAS/DATASUS, 2002.

Nas RMs de Maceió, São Luis e Colar Metropolitano do Vale do Aço, aparecem como principal causa de internaçăo masculina o grupo das Esquizofrenias, Transtornos Esquizotípicos e Delirantes. Esta causa também foi o principal motivo de internação feminina nas RMs de Maceió, Săo Luis e Colar, enquanto que os Transtornos Mentais Orgânicos, foram a principal causa de internaçăo na RM do N/NE de Sta Catarina, e os Transtornos do Humor aparecem nas RMs de Porto Alegre e Campinas. (Tabela 35)

\section{Doenças do Aparelho Circulatório}

No caso das Doenças do Aparelho Circulatório (IX), esperávamos encontrar nas RMs com melhor IDH as maiores taxas de internaçăo, porém, foram as regiōes de São Luis e Colar Metropolitano do Vale do Aço as que apresentaram as maiores taxas por essa causa (Gráfico17). 
Gráfico 17: Taxa de internação por Doenças do Aparelho Circulatório, para o grupo etário de 15 a 49 anos. Regiões Metropolitanas, 2002 (por 100.000 habitantes)

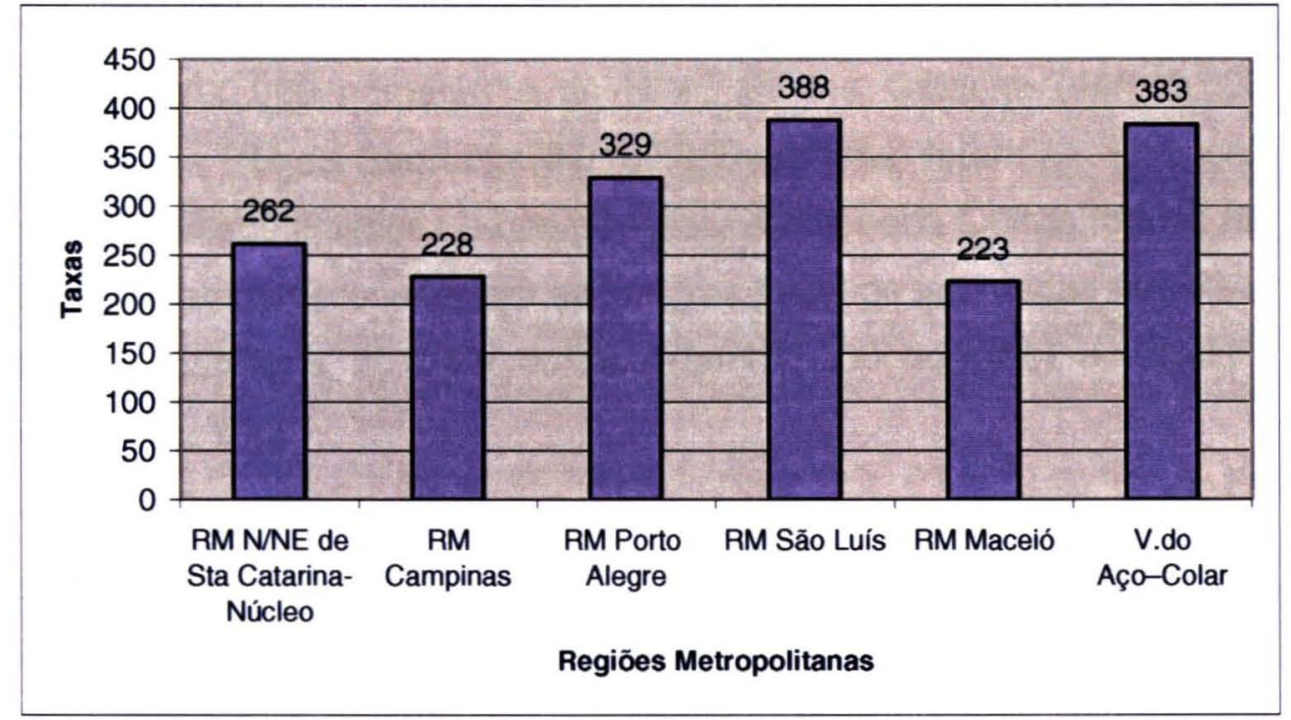

Fonte: MS/SAS/DATASUS, 2002.

Para o total da população do grupo de 15 a 49 anos, dentro do capítulo das Doenças do Sistema Circulatório (IX), as Doenças das veias, dos vasos linfáticos e dos gânglios foram a principal causa de internação nas RMs de São Luis (253/100.000 habitantes) e Campinas (76/100.000 habitantes). As Doenças isquêmicas do coração foram o principal motivo de internação na RM de Porto Alegre (75/100.000 habitantes). Outras formas de doenças do coração apareceram nas RMs do N/NE de Sta Catarina (106/100.000 habitantes), Colar Metropolitano do Vale do Aço (102/100.000 habitantes) e Maceió (78/100.000 habitantes).

Nas RMs de Campinas, Colar Metropolitano do Vale do Aço e Maceió não existem diferenças significativas nas taxas de internação masculina e feminina por Doenças do Sistema Circulatório. Nas RMs de Porto Alegre, São Luis e N/NE de Sta Catarina; as taxas femininas são significativamente superiores às masculinas (Tabela 32 ).

Entre os homens a maior taxa foi na RM do Colar Metropolitano do Vale do Aço, seguida pela RM de Porto Alegre, Campinas. Para as mulheres, a maior taxa de internação por Doenças do Aparelho Circulatório 
foi encontrada na RM de São Luis, seguida pelas RMs do Colar Metropolitano do Vale do Aço, N/NE de Santa Catarina (tabela 32).

As Doenças isquêmicas do coração foram a principal categoria de internação para os homens das RMs de Porto Alegre (91/100.000 homens), Campinas (61/100.000 homens) e do N/NE de Sta Catarina (44/100.000 homens). Para a RM de São Luis (87/100.000 homens) foram as Doenças das veias, dos vasos linfáticos e dos gânglios. A categoria Outras formas de doenças do coração representaram as maiores taxas de internação nas RMs do Colar Metropolitano do Vale do Aço (94/100.000 homens) e Maceió (83/100.000 homens).

As Doenças das veias, dos vasos linfáticos e dos gânglios foram a principal causa de internação para as mulheres nas RMs de São Luis (395/100.000 mulheres), Colar Metropolitano do Vale do Aço (128/100.000 mulheres), Campinas (99/100.000 mulheres) e Porto Alegre $(82 / 100.000$ mulheres).

\section{Doenças do Aparelho Respiratório}

A maior taxa de internação por esta causa encontramos na RM de Porto Alegre, seguida pela RM do Colar Metropolitano do Vale do Aço (Gráfico 18). 
Gráfico 18: Taxa de internação do grupo etário de 15 a 49 anos, por Doenças do Aparelho Respiratório. Regiões Metropolitanas, 2002.

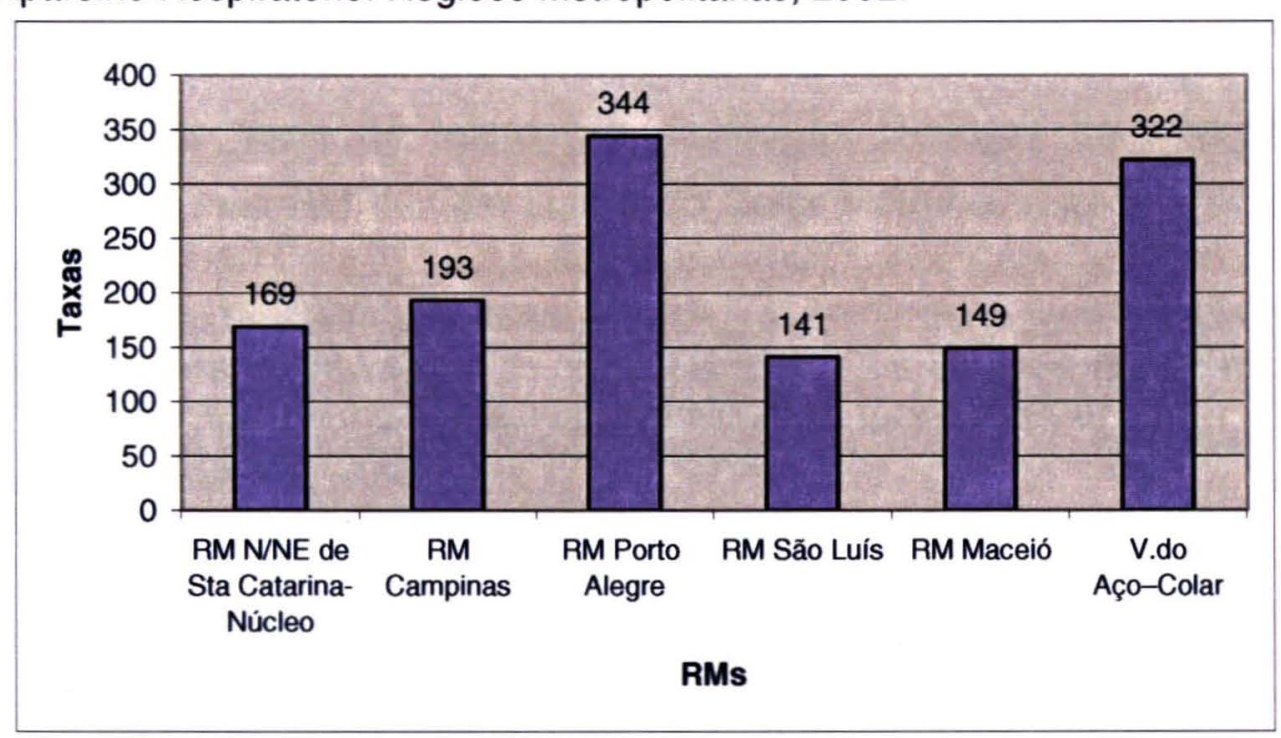

Fonte: MS/SAS/DATASUS, 2002.

Exceto na RM do Colar do Vale do Aço, onde a diferença entre as taxas de homens e mulheres não foi significativa, nas demais, as taxas masculinas foram significativamente maiores que as femininas.

A maior taxa de internação masculina por Doenças do Aparelho Respiratório foi na RM de Porto Alegre, seguida pelo Colar Metropolitano do Vale do Aço, Campinas, N/NE de Sta Catarina, Maceió e São Luis. Para as mulheres, a maior taxa foi no Colar Metropolitano do Vale do Aço, seguida pela RM de Porto Alegre, Campinas, N/NE de Sta Catarina, São Luis e Maceió (Tabela 32).

As principais categorias de internação, dentro das doenças do aparelho respiratório, tanto para homens, quanto para as mulheres, foram gripe (Influenza) e pneumonia, porém sendo inferiores as taxas femininas, em relação às masculinas. 


\section{Doenças do Aparelho Digestivo}

A maiores taxas de internação devido às Doenças do Aparelho Digestivo, foram nas RM de São Luis e do Colar Metropolitano do vale do Aço (Gráfico 19).

Gráfico 19: Taxa de internação do grupo etário de 15 a 49 anos, por Doenças do Sistema Digestivo. Regiōes Metropolitanas, 2002. (por 100.000)

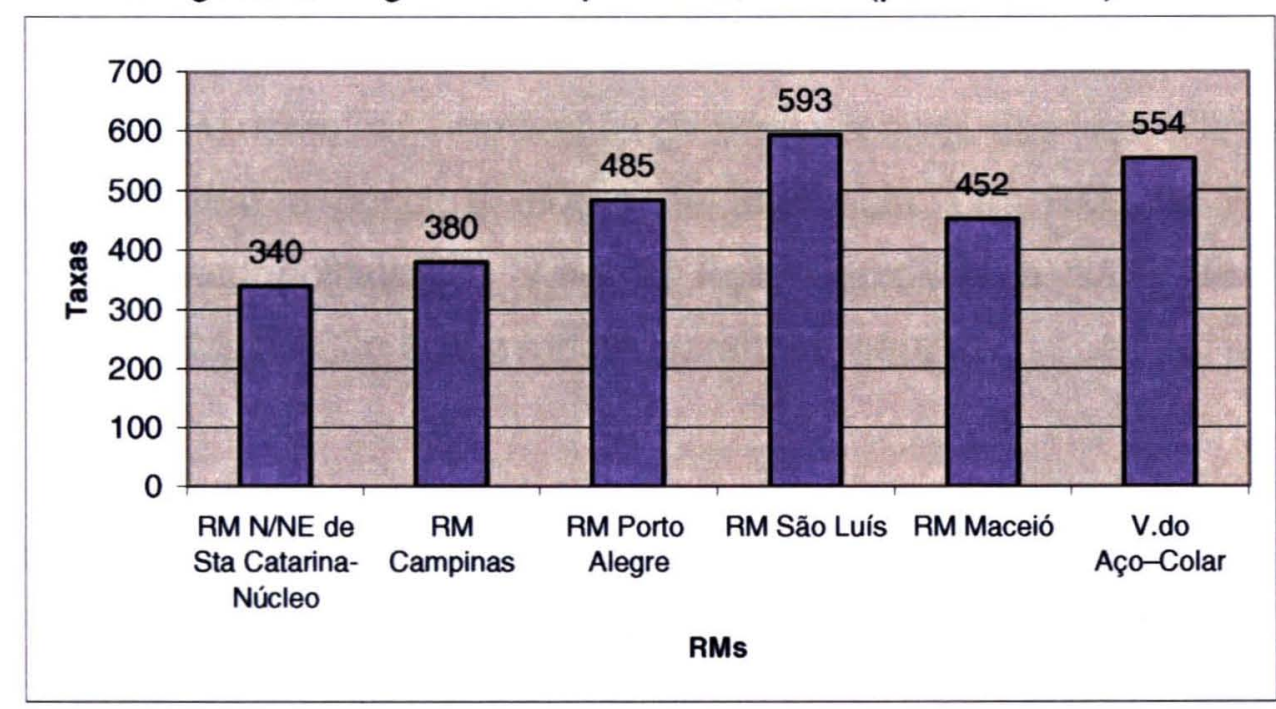

Fonte: MS/SAS/DATASUS, 2002.

Para os habitantes do grupo etário de 15 a 49 , os Transtornos da vesícula biliar, das vias biliares e do pâncreas foram a principal causa de internação nas RMs de Porto Alegre, Campinas e N/NE de Sta Catarina. As Hérnias aparecem nas RMs de São Luis e Maceió, já na RM do Colar Metropolitano do Vale do Aço foram as Doenças do esôfago, do estômago e do duodeno.

As diferenças das taxas foram significativamente maiores para os homens nas RMs do N/NE de Santa Catarina, Campinas, Colar Metropolitano do Vale do Aço e Porto Alegre. Na RM de Maceió não encontramos diferença significativa entre os sexos e, na RM de São Luis, as taxas femininas foram significativamente superiores às masculinas (Tabela 32). 
As maiores taxas masculinas foram na RM do Colar Metropolitano do Vale do Aço e na RM de São Luis. Para as mulheres as maiores taxas foram na RM de São Luis, seguida pelo Colar Metropolitano do Vale do Aço (Tabela 32).

As Hérnias foram a principal causa de internação masculina nas RMs de São Luis, Maceió, Porto Alegre, N/NE de Sta Catarina e Campinas. $\mathrm{Na}$ RM do Colar Metropolitano do Vale do Aço foram as Doenças do esôfago, do estômago e do duodeno.

Para as mulheres, os Transtornos da vesícula biliar, das vias biliares e do pâncreas foram o principal motivo de internação nas RMs de Porto Alegre, Colar Metropolitano do Vale do Aço, Campinas e N/NE de Sta Catarina. Nas RMs de São Luis e Maceió foram as Hérnias.

\section{Doenças do Aparelho Geniturinário}

Para as Doenças do Sistema Geniturinário, as regiões com menor $\mathrm{IDH}$ foram as que apresentaram as maiores taxas (Gráfico 20)

Gráfico 20: Taxa de internação do grupo etário de 15 a 49 anos, por Doenças do Sistema Geniturinário. Regiões Metropolitanas, 2002.

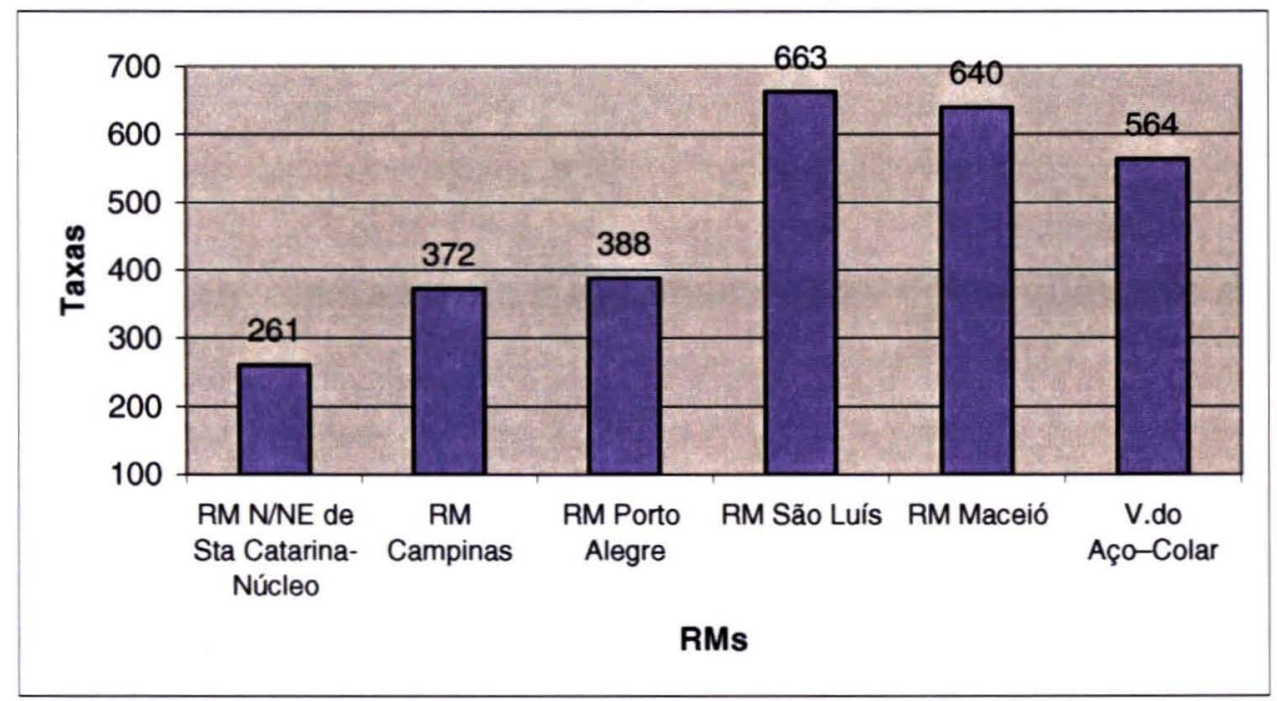

Fonte: MS/SAS/DATASUS, 2002. 
Os principais grupos de enfermidades encontradas foram as Doenças renais túbulo-intersticiais, nas RMs do Colar Metropolitano do Vale do Aço, Porto Alegre e N/NE de Sta Catarina, enquanto que nas RMs de Maceió, São Luis e Campinas foram os Transtornos não-inflamatórios do trato genital feminino.

Em todas as RMs, as taxas de internação feminina foram significativamente superiores às masculinas (Tabela 32 ).

Para os homens a RM com maior taxa de internação foi o Colar Metropolitano do Vale do Aço, seguida por São Luis, Porto Alegre, Maceió, Campinas e N/NE de Sta Catarina (tabela 32).

Por outro lado, para as mulheres das RMs de Maceió, São Luis e Colar Metropolitano do Vale do Aço foram encontradas as maiores taxas e diferenças entre os dois sexos (Tabela 32).

Calculose renal foi a principal causa de internação masculina nas RMs do Colar Metropolitano do Vale do Aço, Campinas e N/NE de Santa Catarina. Na RM de São Luis, foram Outras Doenças do aparelho urinário. Na RM de Porto Alegre foram as Doenças renais túbulo-intersticiais; e, na RM de Maceió, Insuficiência Renal.

Para as mulheres, os Transtornos não-inflamatórios do trato genital feminino foram a principal causa de internação nas RMs de Maceió, São Luis, Colar Metropolitano do Vale do Aço e Campinas. As Doenças renais túbulo-intersticiais aparecem nas RMs de Porto Alegre e N/NE de Sta Catarina.

\section{Lesöes, envenenamento e algumas outras conseqüências de causas externas}

$\mathrm{Na}$ análise das causas externas de morbidade, nos deparamos com uma particularidade do banco da $\mathrm{AlH}$ : o registro do motivo principal da internação ocorre pela natureza da lesão. No diagnostico principal, variável 
que empregamos para o cálculo das taxas de morbidade, está registrado o tipo da lesão e não a sua origem. Frente a essa dificuldade, optamos por utilizar o capítulo XIX (Lesões, Envenenamentos e algumas outras conseqüências de Causas Externas) para o diagnóstico principal das internações e o capítulo XX (Causas Externas de morbidade e mortalidade) para o diagnóstico secundário, na tentativa de alcançar uma aproximação das taxas de internação pela origem da lesão, apesar de problemas relatados com o baixo preenchimento desse campo, pois não se trata de um campo de preenchimento obrigatório.

A RM de São Luis foi a que apresentou a maior taxa de internação por Lesões e Envenenamentos (XIX), seguida pela RM do Colar Metropolitano do Vale do Aço, Porto Alegre, Campinas, Maceió e N/NE de Santa Catarina (Gráfico 21).

Gráfico 21: Taxas de internação para o grupo etário de 15 a 49 anos, por lesões e envenenamentos e algumas outras conseqüências de causas externas. Regiões Metropolitanas, 2002 (100000 habitantes)

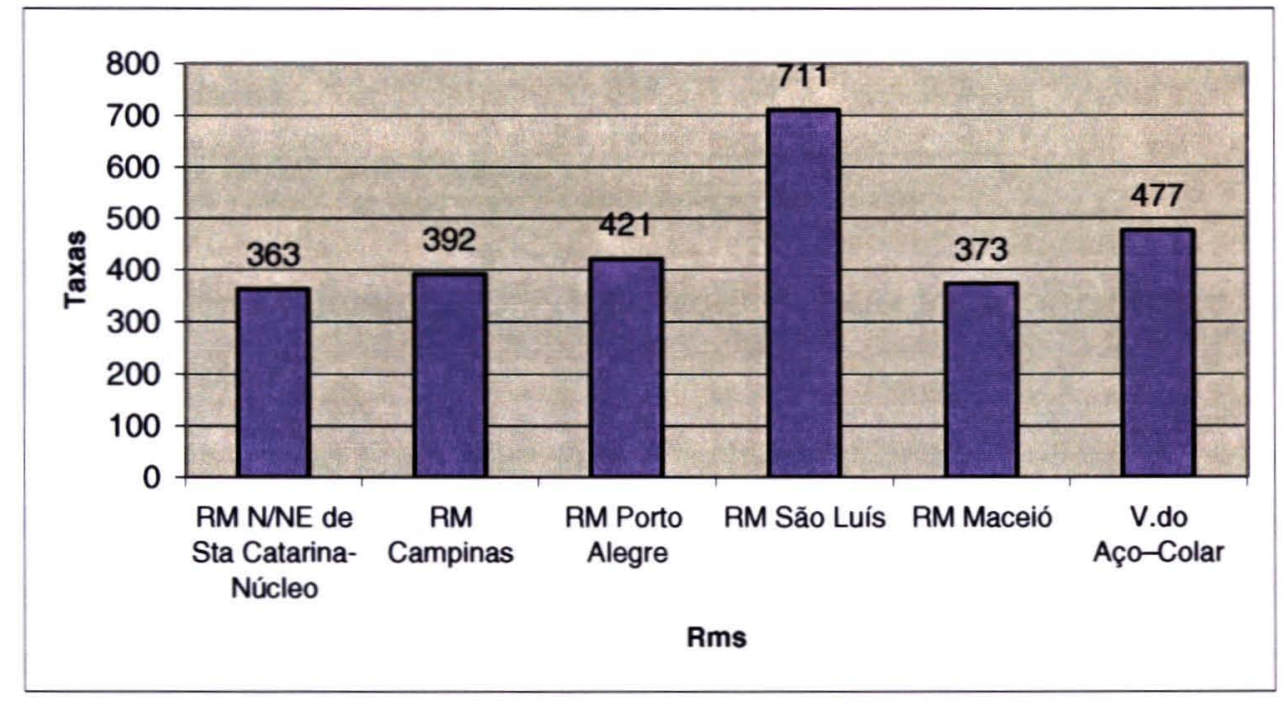

Fonte: MS/SAS/DATASUS, 2002.

Exceto pela RM de São Luis, na qual o principal grupo de morbidade foi o Traumatismo do ombro e do braço, nas demais RMs Traumatismo da cabeça o principal grupo de lesões registradas na $\mathrm{AlH}$.

A taxa de internação geral para o grupo de 15 a 49 anos, na verdade, oculta a diferença existente entre os dois sexos. Em todas as RMs 
estudadas, as taxas masculinas de internação foram significativamente superiores às femininas. Tanto para os homens, quanto para as mulheres, as maiores taxas de internação foram encontradas na RM de São Luis (Tabela 32).

Traumatismo da cabeça foi o principal grupo de lesões, para homens e mulheres no N/NE de Santa Catarina, Campinas, Porto Alegre, Maceió e Colar Metropolitano do Vale do Aço. Na RM de São Luis, o principal grupo para os homens foi o traumatismo de ombro e braço, enquanto que para as mulheres foram as Complicaçōes, cuidados médicos e cirúrgicos NCOP.

Para a variável diagnóstico secundário, na tabela 36 , verificamos que as taxas de internação masculinas por Causas Externas de Morbidade (XX), são superiores à femininas em todas as RMs.

Tabela 36: Taxa de Internação por Causas Externas $(X X)^{*}$ para o grupo etário de 15 a 49 anos

\begin{tabular}{lccc}
\hline RM & masc & fem & Total \\
\hline RM N/NE de Sta Catarina- Núcleo & 562 & 167 & 365 \\
RM Campinas & 618 & 194 & 404 \\
RM Porto Alegre & 690 & 182 & 430 \\
RM Săo Luis & 1199 & 297 & 713 \\
RM Maceió & 618 & 165 & 378 \\
V.do Aço-Colar & 748 & 212 & 483 \\
\hline Fonte: MS/SAS/DATASUS, 2002. & \multicolumn{2}{c}{} \\
Para o cálculo das taxas usamos a varível diagnóstico secundário.
\end{tabular}

Os acidentes foram o principal registro encontrado, superando as agressões (Anexo 7).

As taxas masculinas de lesões autoprovocadas intencionalmente foram superiores às femininas em quase todas as RMs, exceto em Campinas na qual o valor das taxas foi igual, para ambos sexos. Chamou nossa atenção o fato de que na RM de São Luis não encontramos nenhum registro por essa causa (Anexo7)

As taxas masculinas foram superiores em quase todos os grupos de causa, exceto para as Complicaçōes de assistência médica e cirúrgica, em que as mulheres de 15 a 49 anos, da RM do Colar Metropolitano do Vale do Aço, apresentaram taxas de 10 por 100 mil mulheres, enquanto entre os 
homens a taxa foi de 5 por 100 mil. Na RM de São Luis não aparece registro para nenhum dos sexos, para esse tipo de diagnóstico. 


\section{Capitulo VI Discussão}

Estudar a morbidade hospitalar desde uma perspectiva de gênero, implica reconhecer que enquanto as diferenças biológicas se relacionam ao sexo, a categoria gênero pode ser entendida como uma construção social. Portanto, devemos compreendê-la dentro de um contexto sócio-cultural, em um determinado momento histórico. As desigualdades estruturais de homens e mulheres, com papéis e responsabilidades distintas na sociedade, refletem-se em acesso diferenciado à informação, à saúde, à educação e ao poder dentro de uma relação. Neste trabalho, buscamos comparar a morbidade hospitalar masculina e feminina em seis regiōes metropolitanas, usando a variável sexo como uma aproximação da categoria gênero e o IDH das condiçōes socioeconômicas.

O baixo valor do IDH para as regióes metropolitanas selecionadas talvez năo reflita áreas de maior miséria, pois os valores estăo na faixa de 0,500 a 0,799 , considerados de médio desenvolvimento, porém representam 6 realidades distintas. Essa diversidade em parte ocorre pelas diferenças regionais de nosso pais, porém também refletem a falta de critérios claros na definiçăo e criação de uma região metropolitana, prevalecendo muito mais interesses políticos e económicos dos governos.

Apesar de realidades diversas, observamos em todas as regiōes uma reduçăo da fecundidade e da mortalidade, porém em momentos distintos e de forma mais regular nas RMs de Campinas, no Núcleo do N/NE de Santa Catarina e na RM de Porto Alegre e menos nas demais RMs. Entender esse fenômeno como resultado da transiçăo demográfica esbarra em outros dados levantados na pesquisa. A teoria explicativa analisa a relação entre a redução da mortalidade e da fecundidade como resultado de um pensamento racional da sociedade urbano-industrial, porém é criticada por generalizar processos que ocorreram de forma distintas (Oliveira, 1980). No caso das RM estudadas, Maceió, por exemplo, tem a maior Taxa de Fecundidade Geral, mas apresenta um dos maiores graus de urbanização $(96,4 \%)$. 
Quanto à estrutura por sexo, as RM de São Luis e Maceió foram as que apresentaram a relação mais desfavorável entre homens e mulheres para a população de 15 a 49 anos, com uma razão de masculinidade de $857 / 1000$ mulheres e $889 / 1000$ mulheres, respectivamente. Essa desproporção, por uma possivel sobre-mortalidade ou emigração masculina, gera um desequilíbrio demográfico e social, com efeito perverso para a mulher que, nessas situações de ausência masculina, acaba arcando sozinha com o sustento da familia. (Laurenti et al 1998)

Ainda em relação à estrutura da população, observamos que aquelas com pior IDH, Colar Metropolitano do Vale do Aço, RM de Maceió e São Luis, foram as que apresentaram a maior desproporção em relaçăo à população dependente e à população economicamente ativa. Valores altos representam, principalmente nas regiões mais pobres, uma desvantagem econômica que pode ter como conseqüência a exploração do trabalho infantil ou a saída tardia do mercado de trabalho da população idosa.

Uma outra desvantagem feminina encontrada foi em relação à taxa de alfabetização. As RMs do Colar Metropolitano da RM do Vale do Aço, de São Luis e de Maceió apresentam as taxas mais altas de analfabetismo, e esta desvantagem feminina está presente em todas as regiões.

Para analisar a demanda da atenção hospitalar, foi necessário conhecer a oferta desses serviços nas regiōes selecionadas e constatamos que, no ano de 2002, existia uma maior oferta de estabelecimentos com internaçăo nas RMs com IDH mais baixo, exceto no Colar Metropolitano do Vale do Aço. Por outro lado, a oferta de estabelecimentos de Apoio à Diagnose e Terapia foi superior nas RMs com IDH mais alto.

Sabemos que a oferta dos serviços e equipamentos de saúde não garantem o acesso, porém nas regiões estudadas a maior oferta de leitos SUS encontramos nas RMs de São Luis e Maceió. Nessas RMs e no Colar Metropolitano do Vale do Aço, verificamos as maiores taxas de internação financiadas pelos SUS. Por outro lado, nas RMs de Campinas, Porto Alegre e Núcleo da RM do N/NE de Sta Catarina, encontramos as maiores 
porcentagens da populaçăo com cobertura da saúde suplementar. Tais constatações indicam que nas RMs com IDH mais baixo o SUS tenta cobrir minimamente a demanda por serviços de saúde, ou seja, tenta proporcionar uma eqüidade em saúde. Quanto à diferença por sexo, não foi possivel fazer uma comparação, pois dados coletados no site do DATASUS, para internação e consulta médica, não são discriminados por sexo. Pinheiro et al. (2002), usando como fonte a PNAD de 1998, observaram que as mulheres relataram com mais freqüência o uso regular de serviços de saúde, consultas médicas e serviços odontológicos. Enquanto as mesmas procuram mais os serviços para exames de rotina ou cuidados preventivos, os homens buscam os serviços para cuidados curativos.

Na experiência com o SIH constatamos algumas dificuldades, que nos foram alertadas nas leituras sobre esta fonte de dados. A principal dificuldade ocorre devido à própria essência do banco, pois o mesmo não foi idealizado para fornecer dados epidemiológicos, uma vez que, foi criado com - objetivo de controlar o financiamento da rede de atençăo hospitalar, primeiro pela Previdência, depois pelo atual responsável, o Ministério da Saúde.

Em alguns momentos, dados epidemiológicos foram inseridos, mas tendo como foco a criaçăo de algum tipo de controle sobre o pagamento. Um exemplo disto é a vinculação dos procedimentos ao campo de diagnóstico principal, para que a AlH não seja rejeitada. Uma outra situação encontrada é a inserção e coleta de dado epidemiológico novo, em virtude de um interesse técnico momentâneo, que pode ocorrer pela implantação de um programa ou um novo técnico/gestor, são campos que foram inseridos em determinado momento, e com a saída do técnico ou o fim do programa, esse dado deixa de ser coletado, comprometendo uma avaliaçăo da série histórica, por exemplo.

Para exemplificar o que foi dito anteriormente, durante o trabalho exploratório com o banco no campo procedimentos obstétricos, que inclui parto normal e cesárea, curetagens pós-aborto e outras intervençőes 
obstétricas, encontramos um elevadíssimo número de curetagens pósaborto. Pensávamos que com esse dado fosse possível uma aproximaçăo mais exata dos números de abortos realizados no País; porém, em conversa com uma funcionária da auditoria da Secretaria de Estado da Saúde de São Paulo, foi-nos esclarecido que esse número na verdade registra dois tipos de eventos, a curetagem pós-aborto e a curetagem pós-parto. É que, devido às críticas levantadas pelo Programa de Saúde da Mulher, o Ministério da Saúde não paga a curetagem pós parto, pois o pagamento de tal procedimento reforçaria a atenção inadequada ao parto, e por isto os hospitais registram esse procedimento de forma irregular para receberem o pagamento.

As dificuldades alertadas por outros autores e constatadas durante 0 trabalho com o banco, ocorrem em grande parte, devido à falta de uma política clara para a informação em saúde no Brasil.

Enquanto trabalhávamos com os dados, uma outra questão que nos preocupou, e que deve ser levada em consideração na análise das internações, não está relacionada com as características do banco, mas com aspectos sócio-culturais de cada região que interferem na percepção do estar doente dentro de cada grupo.

No levantamento dos dados, usamos sempre o local de residência dos pacientes, porém os resultados aqui obtidos, não representam um perfil epidemiológico da regiâo, pois existe uma demanda reprimida do SUS, que não chega ao serviço hospitalar.

Em um estudo exploratório com o banco, observamos que, em geral, as RMs são referência para outros municipios da própria RM ou de fora dela. A única exceção foi o Colar Metropolitano do Vale do Aço que tem como referência os serviços hospitalares da RM do Vale do Aço.

Com os primeiros resultados foi possível constatar que a principal demanda dos serviços hospitalares financiados pelos SUS em todas as regiōes foram os partos. Naquelas com pior IDH e mais altas taxas de fecundidade, foi onde encontramos as maiores taxas de internação da 
população feminina, de 15 a 49 anos, por motivo de Gravidez, parto e puerpério (cap XV-CID10).

Além das AlHs com diagnóstico de gravidez, também retiramos de nosso trabalho as AHls de tipo 5, pois a abertura de uma AlH deste tipo ocorre depois de ultrapassado o prazo de 107 dias da AlH de tipo1. Em todas as RMs, as internações masculinas, com esse tipo de registro, foram superiores às femininas. Em sua grande maioria, são geradas para cobrir internaçōes psiquiátricas, diagnósticos em que predominam pacientes do sexo masculino.

Retiradas as AlHs citadas anteriormente, verificamos que as maiores taxas de internação foram encontradas nas RMs com pior IDH, não podemos concluir que as pessoas dessas regióes se enfermam mais, pois estão fora de nossa análise as internaçōes da saúde suplementar ou particulares, porém, não podemos deixar de reconhecer que as condições socioeconômicas desfavoráveis, refletem-se em desigualdades na saúde de pessoas ou grupos.

O passo seguinte, foi identificar as principais causas de internação de homens e mulheres. Na tabela 37, apresentamos os diagnósticos por região metropolitana, identificando se as taxas de internação foram estatisticamente significantes para homens ou mulheres. 
Tabela 37: Diagnóstico de internaçăo segundo Região Metropolitana. 2002.

\begin{tabular}{|c|c|c|c|c|c|c|}
\hline Diagnóstico CID10 & $\begin{array}{l}\text { NNE de } \\
\text { Sta Cat }\end{array}$ & Campinas & P Alegre & S Luis & Maceíb & $\begin{array}{l}\text { Vale do } \\
\text { Aço-Colar }\end{array}$ \\
\hline $\begin{array}{l}\text { 1. Algumas doenças } \\
\text { infecciosas e parasitárias }\end{array}$ & $T$ & $M$ & $\bar{M}$ & $M$ & $M$ & $F$ \\
\hline II. Neoplasias (tumores) & $F$ & $\mathbf{F}$ & $F$ & $F$ & $F$ & $\mathbf{F}$ \\
\hline $\begin{array}{l}\text { V. Transtornos mentais e } \\
\text { comportamentais }\end{array}$ & $M$ & $M$ & M & $M$ & $\mathbf{M}$ & $M$ \\
\hline $\begin{array}{l}\text { IX. Doenças do Sistema } \\
\text { Circulatónio }\end{array}$ & $\mathbf{F}$ & 1 & $F$ & $\mathbf{F}$ & 1 & 1 \\
\hline $\begin{array}{l}X \text { Doenças do aparelho } \\
\text { respiratorio }\end{array}$ & M & $\mathbf{M}$ & $\mathbf{M}$ & $\mathbf{M}$ & $\mathbf{M}$ & 1 \\
\hline $\begin{array}{l}\text { XI. Doenças do Sistema } \\
\text { Digestivo }\end{array}$ & $\mathbf{M}$ & $\mathbf{M}$ & $M$ & $\mathbf{F}$ & 1 & $M$ \\
\hline $\begin{array}{l}\text { XIV. Doenças do Sistema } \\
\text { Geniturinário }\end{array}$ & $F$ & $F$ & $\mathbf{F}$ & $F$ & $F$ & $\mathbf{F}$ \\
\hline $\begin{array}{l}\mathrm{XIX} \text {. Lesbes enven e alg out } \\
\text { conseq causas extemas }\end{array}$ & $\mathbf{M}$ & $M$ & $M$ & $\mathbf{M}$ & $M$ & $M$ \\
\hline Total* & $T$ & $M$ & 1 & $F$ & $\bar{F}$ & $T$ \\
\hline
\end{tabular}

Se as diferenças de gênero na saúde podem ser abordadas partindo de um enfoque biomédico que procura identificar as diferenças em termos genéticos, hormonais, anatômicos, por outro lado, esse modelo é confrontado com uma abordagem que busca os riscos e diferenciais que sejam fruto de processos sociais, económicos e culturais, que interferem no processo saúde/doença de homens e mulheres (Kawachi et al. 1999). Uma outra caracteristica do conceito de gênero refere-se a sua transversalidade, pois ele perpassa por outras categorias de análise como raça, etnia e classe social que, segundo Sem (2005), pouco foram explorados no campo da saúde enquanto construções sociais.

Segundo Kawachi (1999), em sociedades desiguais as situações de saúde são desfavoráveis tanto para as mulheres, quanto para os homens. Em nosso trabalho, nas RMs com pior IDH, as internações femininas foram superiores às masculinas. Cooper (2002), em trabalho sobre a morbidade auto-referida de homens e mulheres, considerou que nível socioeconômico e etnia săo elementos que interferem na morbidade. Usando com fonte 0 Health Survey for England, no periodo de 1993-1996, constatou a baixa morbidade de adultos brancos, contrastada com a alta morbidade referida 
por mulheres de minorias étnicas, ou mesmo comparada com homens do mesmo grupo. A alta morbidade de adultos de grupos étnicos em piores condiçőes socioeconômicas muito inferiores aparece na análise de regressão feita pelo autor, que também constatou que as desvantagens são maiores para as mulheres desses grupos.

Sen et al. (2005) lembram que o problema da falta de eqüidade no campo da saúde entre ricos e pobres foi reconhecida desde o século $X I X$, năo ocorrendo o mesmo com as desigualdades de gênero, que somente a partir da década de 70 do século $X X$ passou a ser reconhecido como um fator social de interferência. As desigualdades de gênero no âmbito da saúde podem se revelar de distintas formas. Sen et al. (2005) alertam para o problema da falta de uma perspectiva de gênero nas investigações clínicas e no teste de novos medicamentos. Segundo as autoras, os problemas de saúde que afetam as mulheres sempre receberam menor atenção e menos recursos do que aqueles que afetam os homens.

As mulheres são excluídas na maioria dos estudos de medicamentos, sob o argumento de que o ciclo menstrual introduz variáveis de confusăo, porém quando esse medicamento passa a ser comercializado, elas também săo consumidoras. Pesquisas no campo da epidemiologia cardiovascular mostraram que os modelos de diagnóstico para esse tipo de enfermidade são feitos, na maioria das vezes, baseados em homens. Porém, os sintomas diferem entre os sexos. Portanto no momento de realizar o diagnóstico, o profissional médico, tarda mais em reconhecer os sintomas em uma mulher (Sen et al 2005).

As desigualdades de gênero na saúde não se restringem somente aos aspectos relatados anteriormente. As vulnerabilidades também são distintas. Em nosso trabalho, enquanto as Neoplasias e as Doenças do Aparelho Geniturinário foram significativamente superiores para as mulheres, para os homens predominaram as lesőes e os transtornos mentais. 
Rea e colaboradores (Berquó e Cunha, 2000) relatam que a prevalência de internação feminina doenças do aparelho geniturinário é fato conhecido, e a causa estaria relacionada à "formação anatômica e ausência de noções de higiene" (p.175). Nesse sentido, sublinhariamos como "noçōes de higiene " as condições de higiene e de precariedade sócioeconômica , como demonstram a existência de taxas muito maiores para as mulheres nas regiōes de menor IDH. Acrescentariamos a isso também como indagação se o fato da reprodução e da anatomia sexual também vulnerabilizarem mais as mulheres nesse grupo de causas, inclusive também por serem mais significativos nas regiōes de maior taxa de fecundidade.

Laurenti et al. (1998), identificam diferenças em causas específicas de morbidade: enquanto as neoplasias predominam em pacientes do sexo feminino, as causas externas tendem a ter um peso maior para os homens. Outra diferença relatada refere-se ao predomínio masculino em problemas resultantes do uso e abuso do álcool, enquanto que para as mulheres são as doenças do aparelho geniturinário (Berquó e Cunha 2000; Connell 2000).

Para as doenças infecciosas, na maioria das regiőes, as taxas de internação masculina foram superiores à feminina, porém quando desagregamos em grupos, observamos que para os homens nas RMs de Porto Alegre, Campinas, N/NE de Sta Catarina-Núcleo e Maceió as doenças por HIV foram a principal causa de internação. Na RM de São Luis aparecem as doenças bacterianas $e$, dentre elas a hanseniase, com taxa masculina bem superior à feminina. Aliás, exceto pela RM de Porto Alegre, a taxa masculina supera a feminina. A tuberculose também aparece como uma das principais causas de internação masculina, sendo bem superior à feminina.

Chamou nossa atenção que, para as mulheres, as infecções de transmissão predominantemente sexual foram a principal causa de internação feminina nas RMs de Porto Alegre, N/NE de Sta Catarina-Núcleo, 
Colar do Vale do Aço e São Luis, sendo que na RM de Campinas foram as doenças por HIV.

Del Rio (1997, p.15) explica a vulnerabilidade feminina por doenças de transmissão sexual. Primeiro a vulnerabilidade biológica, pois no ato sexual uma grande superficie da mucosa vaginal se expõe ao sêmen, que contêm uma maior concentração de vírus que o fluido vaginal. Vulnerabilidade epidemiológica, pois as mulheres são mais vulneráveis epidemiologicamente. Em geral, casam-se com homens mais velhos que já tiveram mais parceiras sexuais, portanto com maior chance de contrair alguma enfermidade. Além disso, principalmente por motivos obstétricos, recebem mais transfusōes de sangue que os homens. E a vulnerabilidade social, pois a construção social de gênero define que a mulher deve ser submissa, virgem, fiel, enquanto ao homem é permitido ter relações extraconjugais, não negociar o uso do preservativo, já que tem o poder de decisão em uma relação. A vulnerabilidade social da mulher não se limita ao sexual, mas também às condições de desvantagem nos campos educativo, econômico e legal.

Se, por um lado, a construção social de gênero, coloca a mulher em desvantagem nas doenças de transmissão sexual, pelo lado masculino a vulnerabilidade aparece nos transtornos mentais e nas lesões. Em nosso trabalho, verificamos que nas RMs de Campinas, N/NE de Sta Catarina e Porto Alegre as maiores taxas foram pelos transtornos provocados por substâncias psicoativas, principalmente o álcool, e nas demais regiōes, apesar de aparecerem como segunda principal causa de internação, apresentam taxas superiores às anteriores. Na análise das causas externas de morbidade, utilizando o campo diagnóstico secundário, observamos que os acidentes foram o principal registro encontrado, superando as agressões. As taxas masculinas de lesões auto-provocadas intencionalmente foram superiores às femininas em quase todas as RMs, exceto em Campinas na qual o valor das taxas foi igual, para ambos sexos. 
Segundo Connel (2000) existem diversas masculinidades, havendo entre elas diferentes relações de hierarquia: algumas dominam, enquanto outras se submetem a essa ou são marginalizadas. A forma hegemônica ${ }^{7}$ não será necessariamente a mais comum, mas é a referência para as demais, e é também mais valorizada. Elas săo definidas socialmente e sustentadas pelas instituições. A masculinidade tradicional reflete-se em diferenças desvantajosas para os homens nos casos de acidentes, incluídos os de transporte e de trabalho, nas altas taxas de suicídio, 0 abuso de álcool e demais drogas. Segundo esse autor, as diferenças ocorrem porque nas sociedades modernas as estruturas de gênero determinam a divisão do trabalho, o poder, as práticas sexuais e diferenças de identidades que se refletem em comportamentos e riscos distintos. Quando um jovem bebe e dirige perigosamente, não está seguindo seus hormônios, mas sim as regras de masculinidade, pois o consumo de álcool, cigarro e outras drogas relaciona-se a uma imagem masculina de virilidade.

A sobre-mortalidade prematura masculina, deu espaço para um tipo de pensamento que considerava o homem mais vulnerável que a mulher mas, na verdade, trata-se de um paradoxo de gênero, pois se eles morrem mais, por outro lado, são as mulheres quem mais adoecem. Esse paradoxo, segundo Sen et al. (2005), pode ser mais complexo do que se supõe e năo pode ser generalizado para todo tipo de sociedade. No caso da nossa pesquisa, ele se confirma somente para as regiöes com pior IDH, pois conforme se pode observar na tabela (38) apresentada, os homens das RM de Maceió, São Luis e Colar Metropolitano do Vale do Aço, apresentam taxas de mortalidade superiores às das mulheres, enquanto que as mesmas, apresentam maior taxa de morbidade hospitalar. Já nas RMs com melhor IDH, esse paradoxo não se confirma, pois as taxas de internação feminina e masculina foram praticamente iguais, enquanto que na RM de Campinas a internação masculina foi superior.

\footnotetext{
${ }^{7}$ Citamos o raciocinio de Connel (2000) pois este autor faz referéncia direta entre saúde e masculinidade. Tal citaçáo năo implica porém concordância com o conceito de masculinidade hegemónica referida pelo autor. Nesse caso podemos pensar também na existéncia de diversas masculinidades em funçăo de contextos históricos culturais específicos, como a masculinidade mediterrânea ( Almeida, 2000) .
} 
Tabela 38: Taxa de mortalidade por sexo. Regiőes Metropolitanas, 2002.

\begin{tabular}{|c|c|c|c|}
\hline \multirow{2}{*}{$\begin{array}{l}\text { Regiazo Metropolitana } \\
\text { Núcleo da RM do N/NE de Sta }\end{array}$} & \multicolumn{2}{|c|}{ Masculino Feminino } & Total \\
\hline & 248 & 111 & 180 \\
\hline RM de Campinas & 364 & 105 & 234 \\
\hline RM de Porto Alegre & 361 & 141 & 248 \\
\hline RM de São Luís & 269 & 113 & 185 \\
\hline RM de Maceió & 426 & 130 & 270 \\
\hline V.do Aço - colar metrop & 252 & 108 & 181 \\
\hline
\end{tabular}

Fonte: SIM/DATASUS.

Esse fato também pode encontrar eco nos estudos feitos por Cooper (2002) que concluem que em condiçōes sócio-econômicas mais favoráveis as diferenças na magnitude da morbidade entre homens e mulheres tendem a ser menores.

Cabe também levantar que o reflexo das causas externas, nas quais se evidencia uma das grandes diferenças de mortalidade entre homens e mulheres (Laurenti 1998, Connel 2000), vai aparecer na morbidade hospitalar fundamentalmente através dos acidentes, com taxas mais ou menos semelhantes nas regiōes investigadas, excetuando-se a RM de São Luis e a RM Colar Metropolitano do Vale do Aço. No caso da primeira, o coeficiente de internação por acidente equivale a quase 0 dobro do registrado nas outras regiōes e no Vale do Aço se apresenta com acréscimo superior $20 \%$. Por outro lado, o peso das agressões que poderiam se relacionar como causa dos homicídios nos dados de morbidade, apresentam uma taxa muito baixa em todas as regiōes, talvez devido ao grande índice de fatalidade que possa ocorrer antes da intervenção hospitalar ou e também ao possivel sub registro em função das implicações legais. 


\section{CONSIDERAÇÕES FINAIS}

Iniciamos esse trabalho buscando analisar a morbidade hospitalar partindo de um enfoque de gênero. Para isso, utilizamos o principal sistema existente no País: o Sistema de Informação Hospitalar-SIH.

Durante nosso percurso de trabalho, constatamos que apesar de existirem grandes bancos de dados de morbidade no pais, eles carecem de variáveis que permitam uma análise de gênero, enquanto categoria transversal que passa também pelas condições socioeconômicas, étnicas e raciais. No caso do Sistema de Informação Ambulatorial, não é possível nem mesmo uma desagregação por sexo. Um Sistema de Informação, em uma sociedade que busca a equidade em saúde, deve ser reconhecer que existem diferenças e buscar captá-las.

$\mathrm{Na}$ exploração bibliográfica destaca-se que poucos estudos têm demonstrado essa preocupaçăo, e daí também a dificuldade em trabalhar com o tema. Com esse trabalho foi possivel também constatar a necessidade de estudo qualitativos, que possibilitem aprofundar nas diferenças de gênero que reflitam em desigualdades na saúde.

O campo de estudos que vem se denominando também como estudos de gênero, mais recentemente, vem registrando o estudo das masculinidades. Se entendermos gênero como uma categoria relacional, consideramos que observar a atenção a saúde e sua relação com os homens, também significa compreender os problemas de saúde das mulheres.

Com este trabalho, foi possivel constatar a dificuldade de transpor os limites da variável sexo e seu uso como indicador para articular a discussão com a categoria gênero, fizemos isso com o apoio da literatura existente e ainda destacamos a necessidade de aprofundar, esbarrando na limitaçăo dos bancos de dados e na necessidade de estudos mais contextuais $e$ discriminativos. 
Podem existir sociedades em que as condiçőes socioeconômicas desiguais reflitam em menores desvantagens para as mulheres, porém em nosso estudo consideramos que a vulnerabilidade feminina é ainda maior nesse contexto.

Finalmente, encontramos diferenças nos perfis de morbidade com a utilização da variável sexo, entretanto observamos que estas se acentuam ou ganham contornos quando relacionadas com as condições de vida e o nível socioeconómico,.como, apesar dos problemas que apontamos na delimitação das RMs no Brasil, constatamos com esse trabalho. 


\section{Referências}

Adorno RCF, Betini G. Relatório de pesquisa: saúde sexual e reprodutiva dos adolescentes e jovens do sexo masculino. São Paulo: OPAS/ Faculdade de Saúde Pública; 2000.

Almeida MV. Senhores de si: uma interpretação antropológica da masculinidade. Lisboa: Fim de Século; 2000. Adão e Eva revisitados: o gênero antes do feminismo; p.71-127.

Almeida MF. Algumas considerações sobre os sistemas de informação em saúde da França e Brasil. Inf Epidemiol SUS 1996; (4): 7-12.

Alvarez SE. A "globalização" dos feminismos latino-americanos: tendências dos anos 90 e desafios para o novo milênio. In: Alvarez SE, Dagnino E, Escobar A, organizadores. Cultura e política nos movimentos latino- americanos. Belo Horizonte: UFMG; 2000. p.385-426.

Aquino EML, Menezes GMS, Amoedo MB. Gênero e saúde no Brasil: considerações a partir da pesquisa nacional por amostra de domicílios. Rev Saúde Pública 1992; 26 (3): 195-202.

Aquino EML, Araujo TVB de, Marinho LFB. Padrões e tendências em saúde reprodutiva no Brasil: bases para uma análise epidemiológica. In Giffin K, Costa $\mathrm{SH}$, organizadores. Questões de saúde reprodutiva. Rio de Janeiro: Fiocruz; 1999. p.19-39.

Augusto MHO. Políticas públicas, políticas de saúde e políticas de saúde: algumas questões para reflexão e debate. Tempo Soc Rev Sociol USP 1989; 1 (2): $105-19$.

Ávila MB. Modernidade e cidadania reprodutiva. Estud Fem 1993; 1 (2): 382-93.

Ávila MB, Corrêa S. O movimento de saúde e direitos reprodutivos no Brasil: revisitando percursos. In: Galvão L, Díaz J, organizadores. Saúde sexual e reprodutiva no Brasil. São Paulo: Hucitec/ Population council; 1999. 
Ávila MB, Gouveia T. Notas sobre direitos reprodutivos e direitos sexuais. In: Parker R, Barbosa RM, organizadores. Sexualidades brasileiras. Rio de Janeiro: Relume Dumará; 1996. p. 160-72

Azerêdo S. Teorizando sobre gênero e relações raciais. Estud Fem 1994; $\left(n^{\circ}\right.$ esp.): 203-16.

Bairros L. Nossos feminismos revisitados. Estud Fem 1995; 3 (2): 458-78.

Baitello Junior NB. A sociedade da informação. São Paulo Perspec 1994; 8 (4): 19-21.

Baldijão MFA. Sistemas de informação em saúde. São Paulo Perspec 1992; 6 (4): 21-8.

Barata RB, Almeida MF de, Montero CV, Silva ZP da. Desigualdades em saúde segundo gênero entre jovens e adultos, Brasil, 1998. (in press).

Barata RB, Almeida MF de, Montero CV, Silva ZP da. Desigualdades em saúde segundo etnia em indivíduos de 15 a 64 anos de idade, Brasil, 1998. (in press).

Barbieri T. Sobre la categoria género: una introducción teorico-metodológico. In: Azerêdo $S$, Stolcke V, organizadores. Direitos reprodutivos. São Paulo: Fundação Carlos Chagas; 1991. p.25-45.

Barreto AA. A questão da informação. São Paulo Perspec 1994; 8 (4): 3-8.

Batista LE. Alguns aspectos das politicas de saúde da mulher no Brasil- o PAISM: um estudo de caso. In: Sacvone L, Batista LE, organizadores. Pesquisas de gênero: entre o público e privado. Araraquara:Cultura Acadêmica; 2000. p.4967.

Berquó ES. Fatores estáticos e dinâmicos (mortalidade e fecundidade). In: Santos JLF, Levy MSF, Szmrecsanyi T, organizadores. Dinâmica da população: teoria, métodos e técnicas de análise. São Paulo: T. A. Queiroz; 1980. p.2185. 
Berquó E. O Brasil e as recomendações do plano de ação do Cairo. In: Bilac ED, Baltar MIB, organizadores. Saúde reprodutiva na América latina e no Caribe: temas e problemas. Campinas: PROLAP/ ABEP/ NEPO/ UNICAMP/ Ed 34; 1998. p. 23-35.

Berquó ES, Cunha EMGP, organizadores. Morbimortalidade feminina no Brasil (1979-1995). Campinas: UNICAMP; 2000.

Bronfaman $M$. et al. SIDA, enfermedades de transmisión sexual y salud reproductiva. México: El Colegio de México; 1995.

Carvalho DM. Grandes sistemas nacionais de informação em saúde: revisão e discusão da situação atual. Inf Epidemiol SUS 1997; (4):7-47.

Carvalho MP. Gênero e trabalho docente: em busca de um referencial teórico. In: Bruschini C, Hollanda HB de, organizadores. Horizontes plurais: novos estudos de gênero no Brasil. São Paulo: Fundação Carlos Chagas/ Ed. 34; 1998 . p.381409.

Connel RW. The men and the boys. Cambridge (UK): Polity Press; 2000. Debates about men, new research on masculinities; p.3-195

Copper H. Investigating socio-economic explanations for gender and ethnic inequalities in health. Soc Sci Med 2002; 54: 693-706.

Correa S. "Salud reproductiva", género y sexualidad: legitimación y nuevos interrogantes. [Apresentado ao Seminário do Programa Salud reproductiva y Sociedad; 1996 nov.; México, (DF)].

Costa AM. Desenvolvimento e implementação do PAISM no Brasil. In: Giffin K, Costa $\mathrm{SH}$, organizadores. Questões de saúde reprodutiva. Rio de Janeiro: Fiocruz; 1999. p.19-39.

Del Rio Chiroboga C. Introducción. Mujer y SIDA: Conceptos sobre el tema. In RICO, B. et al. Situación de las mujeres y el VIH/SIDA en América Latina. México: Instituto Nacional de Salud Pública; 1997.

Demo P. Política social, educação e cidadania. Campinas: Papirus; 1994. 
Dora DD. Direitos sexuais, direitos reprodutivos e direitos humanos: conceitos em movimento. In: Arilha M, Citelli MT, organizadores. Políticas, mercado, ètica: demandas e desafios no campo da saúde reprodutiva no Brasil. São Paulo: Ed 34/ Comissão de Cidadania e Reprodução; 1998. p.71-80.

Duncan BB, Schmidt MI, Polanczyk CA, Homrich CS, Rosa RS, Achutti AC. Fatores de risco para doenças não-transmissiveis em área metropolitana na região sul do Brasil: prevalência e simultaneidade. Rev Saúde Pública 1993; 27 (1): 43-8.

Dunnell $\mathrm{K}$, Fitzpatrick J, Bunting J. Making use of official statistics in research on gender and helth status: recent data. Soc Sci Med 1999; 48: 117-27.

Eco H. Como se faz uma tese. São Paulo: Perspectiva; 1989.

Emslie C, Hunt K, WattG. Invisible women? The importance of gender in lay beliefs about herat problems. Sociol health IIIn 2001; 23 (2): 203-33.

Emslie C, Fuhrer R, Hunt K, Macintrye S, Shipley M, Stansfeld S. Gender differences in mental helth: evidence from three organizations. Soc Sci Med 2002; 54: $621-4$.

Ferrando MG. Socioestadistica: introducción a la estadistica em la sociologia. $3^{\text {a }}$ ed. Madrid: Alianza editorial; 1989.

França SB. A hegemonia do SUS e a relação público/privado na assistência hospitalar. Brasília: ENAP; 2002.

Fuhrer R, Stansfeld SA. How gender affects patterns of social relations and their impact on health: a comparison oh one or multiple sources of support from "close persons". Soc Sci Med 2002; 54: 811-25.

Fundação IBGE. Pesquisa de assistência médico sanitária: 2002. Disponivel em <URL: http://www datasus.gov. br> [2004 jul. 29]

Galvão L. Saúde sexual e reprodutiva, saúde da mulher e saúde materna: a evolução dos conceitos no mundo e no Brasil. In: Galvão L, Diaz J, 
organizadores. Saúde sexual e reprodutiva no Brasil. São Paulo: Hucited Population council; 1999.

Giddens A. As conseqüências da modernidade. $2^{\mathrm{a}}$ ed. São Paulo: UNESP; 1991.

Giddens A. A transformação da intimidade. São Paulo: UNESP; 1993.

Giddens A. Para além da esquerda e da direita: o futuro da política radical. São Paulo: UNESP; 1996.

Gómez-Gómez E. Discriminación por sexo y sobre mortalidad femenina en la niñez. In: OPAS. Genero, mujer y salud: en las Americas. Estados Unidos: OPAS; 1993. p. 27-45.

Gouvea CS, Travassos C, Fernández C. Produção de serviços e qualidade da assistência hospitalar no estado do Rio de Janeiro, Brasil- 1992 a $1995 . \quad$ Rev Saúde Pública 1997; 31 (6): 601-17.

Gove WR, Hughes M. Possible caused on the apparent sex differences in physical health: an empirical investigation. Am Sociol Rev 1979; 44: 126-46.

Greig A, Kimmel M, Lang J. Men, masculinities e development: broadening our work towards gender equality. 2000. (monograph series- 10- Gender in Development Programme)

Guimarães NA. Regiōes metropolitanas: aspectos jurídicos. Disponivel em: <URL: http:// www.jus.com. br/doutrina/texto. asp?id=5050> [2004 ago. 18].

Heilborn ML. Gênero, sexualidade e saúde. In: Silva DPM, organizador. Saúde, sexualidade e reprodução: compartilhando responsabilidades. Rio de Janeiro: UERJ; 1996. p.101-11.

Heilborn ML, Sorj B. Estudos de gênero no Brasil. In: Miceli S, organizador. que ler na Ciência Social brasileira: (1970-1995). São Paulo: Sumaré; ANPOCS/ Brasília: CAPES; 1999. p.183-235.

Hotz EF. A organização metropolitana pós-constituição de 1988. São Paulo Perspec 2000; 14 (4): 91-8. 
Hunt K, Annandale E. Relocating gender and morbidity: examining men's and women's health in contemporary western societies. Introduction to special issue on gender and health. Soc Sci Med 1999; 48: 1-5.

Informe Epidemiológico SUS. FUNASA CENEPI. Brasilia (DF) 1995; 4.

Informe Epidemiológico SUS. CENEPI. Brasília (DF) 2000; 9 (2).

Jacobi $P$. Participação e gerência dos serviços de saúde: desafios e limites no município de São Paulo. Rev. Adm. Pública 1992; 26 (2): 32-43.

Kawachi I, Kennedy BP, Gupta V, Prothrow-Stith D. Women's status and health of women and men: a view form states. Soc Sci Med 1999; 48: 21-32.

Langford RA, Ritchie J, Ritiche J. Suicidal behavior in a bicultural society: a review of gender an cultural differences in adolescents and young persons of Aotearoa/ New Zealand. Suicide life threat behav 1998; 28 (1):94-106.

Laurenti R, Mello Jorge MHP de, Lebrão ML, Gotlieb SLD. Estatísticas de saúde. São Paulo: EPU; 1987

Laurenti R, Buchalla CM, Mello Jorge MHP de, Lebrão ML, Gotlieb SLD. Perfil epidemiológico da saúde masculina na região das Américas: uma contribuição para o enfoque de gênero. São Paulo: FSP/ USP; 1998.

Lebrão ML. Determinantes da morbidade hospitalar em região do estado de São Paulo (Brasil). Rev Saúde Pública 1999; 33 (1): 55-63.

Leigh JP, Fries JF. Education, gender, and the compression of morbidity. Int $\mathbf{J}$ Aging Hum Dev 1994; 39 (3): 233-46.

Lopes EFT. A produção de procedimentos de alta complexidade nos setores público e privado: um estudo baseado em internações hospitalares na cldade de São Paulo em 1998. São Paulo; 2001. [Dissertação- MestradoFaculdade de Medicina da USP].

Louro GL. Gênero, história e educação: construção e desconstrução. Educ Real 1995; 20 (2): 101-32. 
Louro GL. Nas redes do conceito de gênero. In: LOPES MJM, Meyer DE, Waldow VR, organizadores. Gênero e saúde. Porto Alegre: Artes Médicas; 1996.

Macintyre S, Ford G, Hunt K. Do women 'over-report' morbidity? Men's and women's responses to structured prompting on a standard question on long standing illness. Soc Sci Med 1999; 48: 89-98

Marin-León L, Barros MBA. Mortes por suicídio: diferenças de gênero e nível socioeconômico. Rev Saúde Pública 2003; 37 (3): 357-63.

Martins $M$, Travassos $C$. Assessing the availability of casmis information in hospital database systems in Rio de Janeiro, Brazil. Int J Qual Health care 1998; 10 (2): 125-33.

Martins M, Travassos C, Noronha JC. Sistema de informações hospitalares como ajuste de risco em índices de desempenho. Rev Saúde Pública 2001; 35 (2): 185-92.

Mason KO. Gender and demographic change: what do we know? Liege: International Union for the scientific Study of Population; 1995.

Mathias TAF, Soboll MLMS. Confiabilidade de diagnósticos nos formulários de autorização de internação hospitalar. Rev Saúde Pública 1998; 32 (6): 526-32.

Mejía MC. Cairo + 5 El consenso de el Cairo en Riesgo? Conciencia Latinoam 1999; 11 (2): 1-5.

Mendes ACG, Silva Junior JB, Medeiros KR, Lyra TM, Melo Filho DA de, Sá DA de. Avaliação do sistema de informações hospitalares-SIH/SUS como fonte complementar na vigilância e monitoramento de doenças de notificação compulsória. Inf Epidemiol SUS 2000; 9 (2):67-87.

Meneghel SN, Abbeg C, Bastos R. "Os vivos são sempre cada vez mais governados pelos mortos": um estudo exploratório sobre a desigualdade no morrer. Hist Ciênc Saúde 2003; 10 (2): 683-702.

Meyer DEE. Gênero e saúde: indagações a partir do pós-estruturalismo e dos estudos culturais. Rev Cienc Saúde 1998; 17 (1): 13-33. 
Minayo MCS. Pesquisa social. 3 ed. Petrópolis: Vozes; 1994.

Ministério da Saúde. Fundação Nacional de Saúde. Centro Nacional de epidemiologia. Sistema de Informações em Saúde. Inf Epidemiol SUS 1995; 6 (4): $85-95$

Ministério da Saúde. Movimento de autorização de internação hospitalar2002. [CD-ROM] SAS/DATASUS. Brasilia.

Ministério da Saúde. Orientações técnicas sobre o Sistema de Informações Ambulatoriais (SIA) e Sistema de Informações Hospitalares (SIH). Brasília: Departamento Nacional de Auditoria do SUS; 2002. (série A: Normas e Manuais Técnicos)

Ministério da Saúde. Secretária Executiva. Tab para windows. [programa de computador]. Brasilia: Datasus/ Departamento de Informática do SUS.

Moraes IHS. Informações em saúde: da prática fragmentada ao exercício da cidadania. Rio de Janeiro: ABRASCO/ São Paulo: HUCITEC; 1994.

Moraes IHS, Santos SRFR dos. Informações para a gestão do SUS: necessidades e perspectivas. Inf Epidemiol SUS 2001; 10 (1): 49-56.

Mostafa SP. As ciências da informação. São Paulo Perspec 1994; 8 (4): 22-7.

Moura R, Delgado $P$, Deschamps $M$, Cardoso NA. A realidade das áreas metropolitanas e seus desafios na federação brasileira: diagnóstico socioeconômico e da estrutura de gestão [Trabalho apresentado ao Seminário Internacional "Desafio da Gestão das Regiões Metropolitanas em Países Federados"; 2004 mar. 30-31; Brasilia, (BR)]. Brasília: Ministério das Cidades, Câmara dos Deputados, Fórum das Federações; 2004. p.1-30

Murphy E et al. Eliminó El Cairo a la población de las políticas poblacionales? Rev Estud Demogr Urbanos s.d.; 12 (1/2): 349-66.

Offe C, Lenhardt G. Teoria do estado e politica social. In: Offe C, Traitag B. Problemas estruturais do estado capitalista. Rio de Janeiro: Tempo Brasileiro; 1984. 
Oliveira JPM. Informação, informática e sociedade. São Paulo Perspec 1994; 8 (4): 34-9.

Oliveira MCFA, Szmrecsãnyi MI de QF. Fecundidade In: Santos JLF, Levy MSF, Szmrecsanyi T, organizadores. Dinâmica da população: teoria, métodos e técnicas de análise. São Paulo: T. A. Queiroz; 1980. p.185-208.

Osis MJMD. PAISM: um marco na abordagem da saúde reprodutiva no Brasil. Cad Saúde Pública 1998; 14 (supl1): 25-32.

Pinheiro RS, Viacava F, Travassos C, Santos-Brito A dos. Gênero, morbidade, acesso e utilização de serviços de saúde no Brasil. Ciênc Saúde Colet 2002; 7 (4):687-707.

Pitanguy J. O Movimento nacional e internacional de saúde e direitos reprodutivos. In: Giffin K, Costa SH, organizadores. Questões de saúde reprodutiva. Rio de Janeiro: Fiocruz; 1999. p.19-39.

Portela MC, Schramm JMA, Pepe VLE, Noronha MF, Pinto CAM, Cianelli MP. Algoritmo para a composição de dados por internação a partir do sistema de informações hospitalares do Sistema Único de Saúde (SIH/SUS)- Composição de dados por internação a partir do SIHISUS. Cad Saúde Pública 1997; 13 (4): 771 4.

Rea MF, coordenador. Morbimortalidade feminina no Brasil (1979-1995): São Paulo. In: Berquó ES, Cunha EMGP da, organizadores. Morbimortalidade feminina no Brasil (1979-1995). Campinas: Unicamp; 2000. cap.6.

Rede Interagencial de Informações para a Saúde. Indicadores básicos de saúde no Brasil: conceitos e aplicações. Brasilia: OPAS; 2002.

Rodrigues JA. Políticas públicas e políticas sociais. São Paulo Perspec 1991; 5 (1): 11-8.

Rodrigues AD. A experiência cultural na era da informação. Margem 1994; (3): 75-84. 
Sabo, D. Comprender la salud de los hombres. USA: OPAS/Harvard Center for population and Development Studies; 2000. (Publicacion Ocasional $n^{\circ} 4$ ). Disponivel em <URL: http//www.paho.org> [2005 fev.19]

Saffioti HIB. Rearticulando gênero e classe social. In: Costa AO, Bruschini C. Uma questão de gênero. Rio de Janeiro: Rosa dos Tempos/ São Paulo: Fundação Carlos Chagas; 1992. p.183-215.

Saffioti HIB. Posfácio: conceituando gênero. In: Saffioti HIB, Muñoz-Vargas M. Mulher brasileira é assim. Rio de Janeiro: Rosa dos tempos; 1994. p.271-83.

Scatena JHG, Tanaka OY. Utilização do sistema de informações hospitalares (SIH-SUS) e do sistema de informações ambulatoriais (SIA-SUS) na análise da saúde em Mato Grosso. Inf Epidemiol SUS 2001; 10 (1): 19-30.

Scavone L, organizador. Género y salud reproductiva en América Latina. Cartago: Libro Universitario Regional; 1999. Anticoncepción, aborto y tecnologias conceptivas: entre la salud, la ética y los derechos; p.21-56.

Schramm JMA, Szwarcwald CL. Diferenciais nas taxas de mortalidade neonatal e natimortalidade hospitalares no Brasil: um estudo com base no Sistema de Informaçōes Hospitalares do Sistema Único de Saúde (SIH/SUS). Cad Saúde Pública 2000; 16 (4): $1031-40$.

Scott JW. Igualdade versus diferença: os usos da teoria pós-estruturalista. Debate Fem 1988; 14 (1): 203-23.

Scott J. Gênero: uma categoria útil de análise histórica. Educ Real 1995; 20 (2):71-99

Sen G, George A, Ostlin P. Incorporar la perspectiva de género en la equidad en salud: un análisis de la investigación y las políticas. USA: OPAS/OMS/Harvard Center for population and Development Studies; 2005. (Publicación Ocasional $n^{\circ} 14$ ). Disponivel em <URL: http//www.paho.org> [2005 fev. 19]

Senra NC. Por uma disseminação democrática de informações. São Paulo Perspec 1994; 8 (4): 40-6. 
Silva JV. Informação e ação política democrática. São Paulo Perspec 1994; 8 (4): 57-67.

Simões O. Qualificação dos dados do SIH-SUS como fonte para estudos epidemiológicos de demanda por serviços de saúde. São Paulo; 2000. [Dissertação- Mestrado- Faculdade de Medicina da USP].

Simões CCS. Perfis de saúde e mortalidade no Brasil: uma análise de seus condicionantes em grupos populacionais específicos. Brasília: OPAS; 2002.

Stabile C. Pós-modernismo, feminismo e Marx: notas do abismo. In: Wood EM, Foster JB. Em defesa da história: marxismo e pós-modernismo. Rio de Janeiro: Jorge Zahar Editor; 1999. p.145-60.

UNESCO/ PNUD. Atlas do Desenvolvimento Humano no Brasil- 2003: entenda o cálculo do Índice do Desenvolvimento Humano Municipal (IDH-M) e saiba quais os indicativos usados. Disponível em: <URL: http:/l Whw. pnud org br>.

Universidade de São Paulo. Faculdade de Saúde Pública. Biblioteca/CIR. Guia de apresentação de tese. São Paulo: USP-Biblioteca- FSP; 1998.

Vieira EM. Políticas públicas e contracepção no Brasil. In: Berquó E., organizador. Sexo e vida: panorama de saúde reprodutiva no Brasil. p.151-96 World Health Organization. Gender and health: technical paper. Geneva: WHO/ FRH/WHD; 1998.

\section{WWW datasus gov.br}




\section{Anexos}

\section{Anexo 1 Descrição dos Registros da AlH} Os campos 22 a 33, a seguir, estão em Reais.

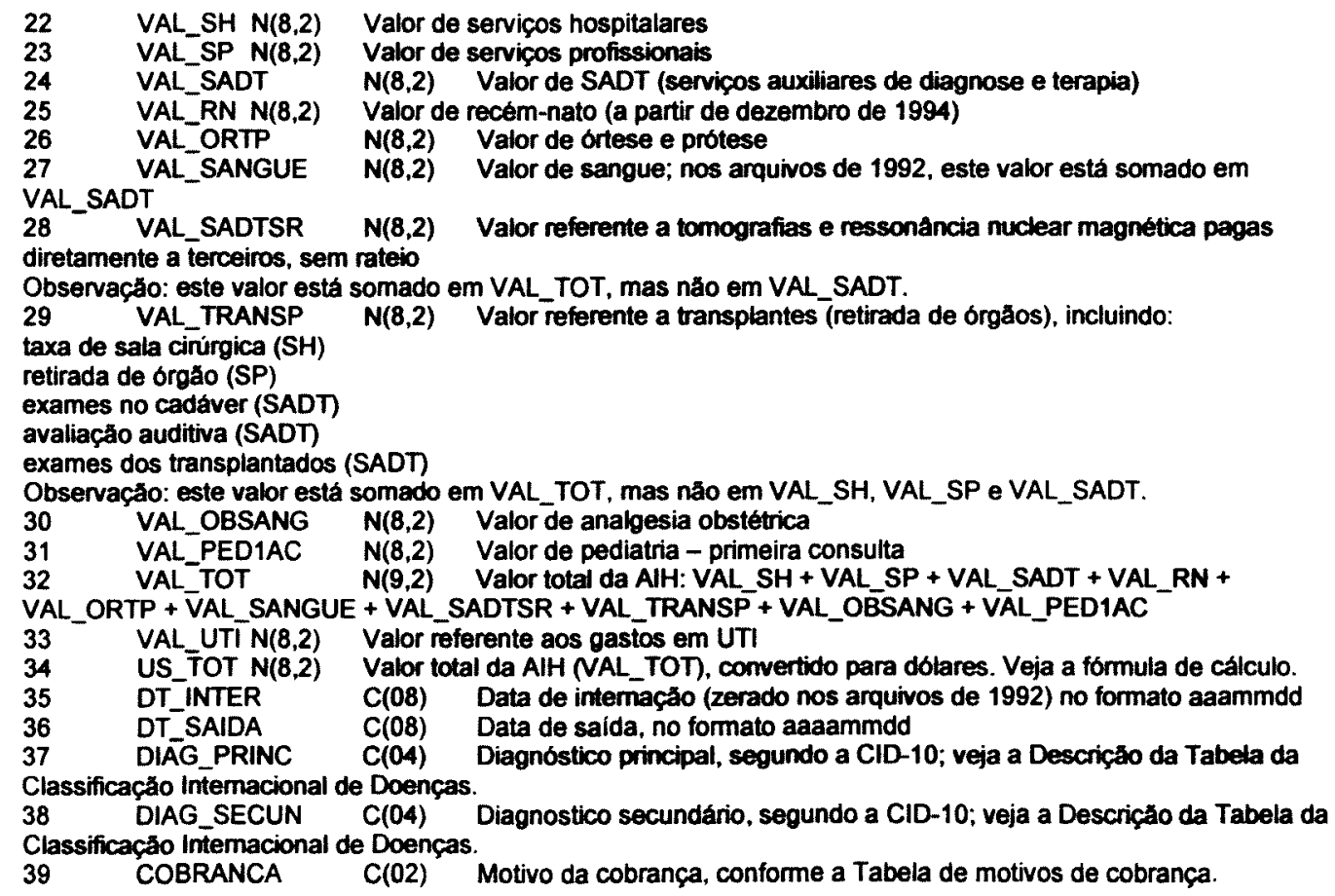




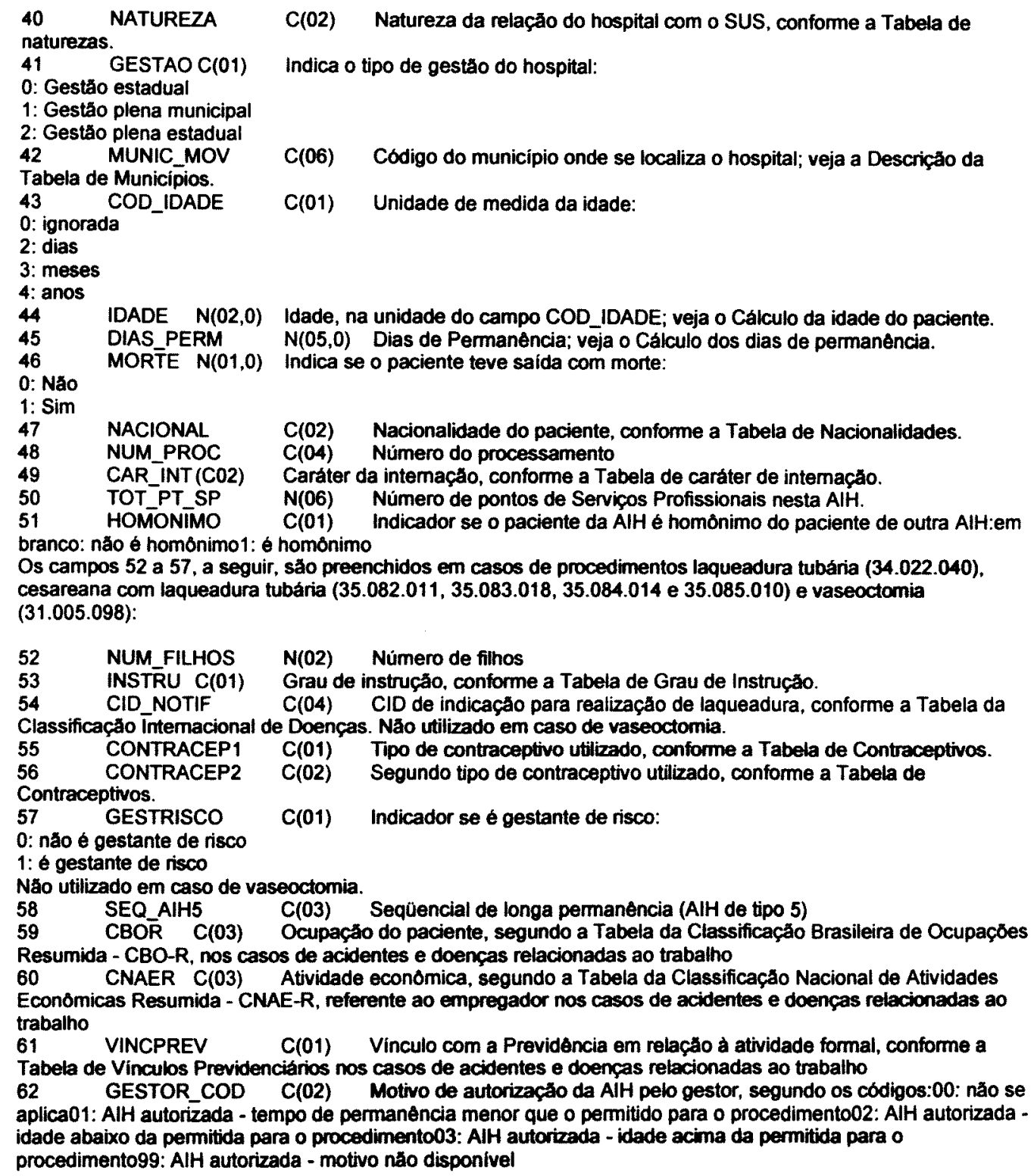

- DATASUS 2003 


\section{Anexo 2 Composição das RMs}

\section{Composição das Regiōes Metropolitanas em 20/02/2002}

\begin{tabular}{|c|c|c|c|c|c|}
\hline CODIGO & NOME_DA_RM & CODIGO & NOME_DO_MUINICIPIO & LEGISLACAAO & DATA_DA_LE \\
\hline 016 & Grande Săo Luis & 2111300 & SAO LUIS & lei complementar 038 & 12.01 .1998 \\
\hline 016 & & 2111201 & SAO JOSE DE RIBAMAR & lei complementar 038 & 12.01 .1998 \\
\hline 016 & & 2107506 & PACO DO LUMIAR & Lei complementar 038 & 12.01 .1998 \\
\hline 016 & & 2109452 & RAPOSA & Lei complementar 038 & 12.01 .1998 \\
\hline 019 & Maceio & 2700508 & $\begin{array}{l}\text { BARRA DE SANTO } \\
\text { ANTONIO }\end{array}$ & lei complementar 018 & 19.11.1998 \\
\hline 019 & & 2700607 & BARRA DE SAOO MIGUEL & lei complementar 018 & 19.11 .1998 \\
\hline 019 & & 2702207 & COQUEIRO SECO & Lei complementar 018 & 19.11 .1998 \\
\hline 019 & & 2704302 & MACEIO & lei complementar 018 & 19.11 .1998 \\
\hline 019 & & 2704708 & MARECHAL DEODORO & lei complementar 018 & 19.11 .1998 \\
\hline 019 & & 2705200 & MESSIAS & lei complementar 018 & 19.11.1998 \\
\hline 019 & & 2706448 & PARIPUEIRA & lei complementar 018 & 19.11 .1998 \\
\hline 019 & & 2706901 & PILAR & lei complementar 018 & 19.11 .1998 \\
\hline 019 & & 2707701 & RIO LARGO & Lei complementar 018 & 19.11 .1998 \\
\hline 019 & & 2707909 & SANTA LUZIA DO NORTE & lei complementar 018 & 19.11 .1998 \\
\hline 019 & & 2708907 & SATUBA & lei complementar 018 & 19.11 .1998 \\
\hline 020 & $\begin{array}{l}\text { Colar Metropolitano } \\
\text { da RM Vale do Aco }\end{array}$ & 3100500 & ACUCENA & lei complementar 051 & 30.12 .1998 \\
\hline 020 & & 3103009 & ANTONIO DIAS & Lei complementar 051 & 30.12 .1998 \\
\hline 020 & & 3106309 & BELO ORIENTE & lei complementar 051 & 30.12 .1998 \\
\hline 020 & & 3108800 & BRAÚNAS & lei complementar 051 & 30.12 .1998 \\
\hline 020 & & 3109253 & BUGRE & lei complementar 051 & 30.12 .1998 \\
\hline 020 & & 3120003 & CORREGO NOVO & lei complementar 051 & 30.12 .1998 \\
\hline 020 & & 3121803 & DIONISIO & lei complementar 051 & 30.12 .1998 \\
\hline 020 & & 3122504 & DOM CAVATI & lei complementar 051 & 30.12 .1998 \\
\hline 020 & & 3123858 & ENTRE FOLHAS & lei complementar 051 & 30.12 .1998 \\
\hline 020 & & 3129301 & IAPU & Lei complementar 051 & 30.12 .1998 \\
\hline 020 & & 3131158 & IPABA & lei complementar 051 & 30.12 .1998 \\
\hline 020 & & 3135001 & JAGUARACQU & lei complementar 051 & 30.12 .1998 \\
\hline 020 & & 3136108 & JOANESIA & Lei complementar 051 & 30.12 .1998 \\
\hline 020 & & 3140308 & MARLIERIA & lei complementar 051 & 30.12 .1998 \\
\hline 020 & & 3141702 & MESQUTTA & lei complementar 051 & 30.12 .1998 \\
\hline 020 & & 3144359 & NAQUE & lei complementar 051 & 30.12 .1998 \\
\hline 020 & & 3149952 & PERIQUITO & lei complementar 051 & 30.12 .1998 \\
\hline 020 & & 3150539 & PINGO D'AGUA & lei complementar 051 & 30.12 .1998 \\
\hline 020 & & 3162609 & SAO JOAO DO ORIENTE & Lei complementar 051 & 30.12 .1998 \\
\hline 020 & & 3163409 & SAO JOSE DO GOLABAL & tei complementar 051 & 30.12 .1998 \\
\hline 020 & & 3167707 & SOBRALIA & lei complementar 051 & 30.12 .1998 \\
\hline 020 & & 3170578 & VARGEM ALEGRE & lei complementar 051 & 30.12 .1998 \\
\hline 022 & Campinas & 3501608 & AMERICANA & lei complementar 870 & 19.06 .2000 \\
\hline 022 & & 3503802 & ARTUR NOGUEIRA & lei complementar 870 & 19.06 .2000 \\
\hline 022 & & 3509502 & CAMPINAS & Lei complementar 870 & 19.06 .2000 \\
\hline
\end{tabular}




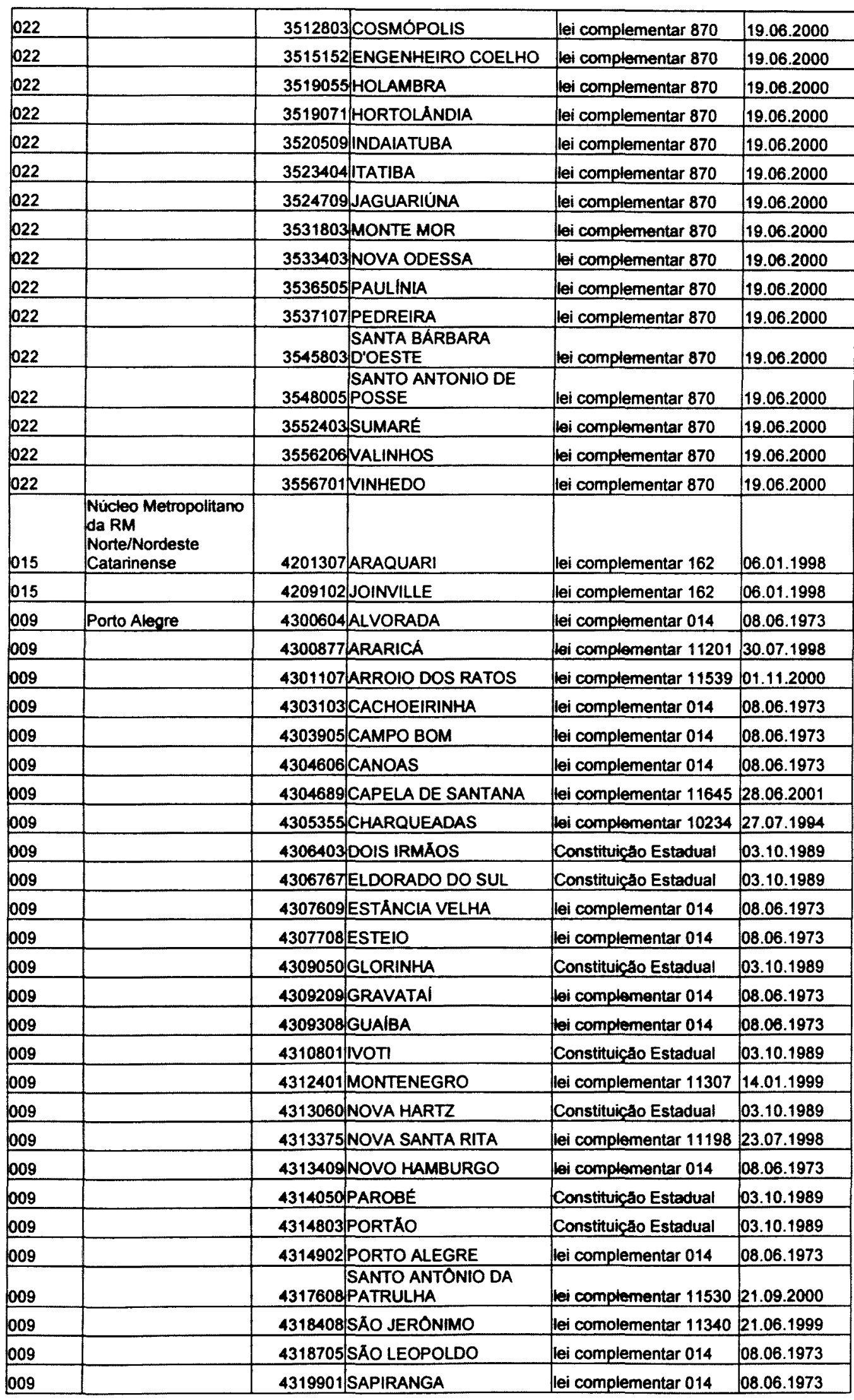




\begin{tabular}{|c|c|c|c|c|}
\hline 009 & 4320008 & SAPUCALA DO SUL & lei complementar 014 & 08.06 .1973 \\
\hline 009 & 432120 & TAQUARA & lei complementar 11318 & 26.03 .1999 \\
\hline 009 & 432200 & TRIUNFO & Constituiçao Estadual & 03.10 .1989 \\
\hline 009 & 432300 & 2VIAMÃO & lei complementar 014 & 08.06 .1973 \\
\hline
\end{tabular}




\section{Anexo 30 cálculo do IDH}

\section{Entenda o cálculo do IDH Municipal (IDH-M) e saiba quais os indicadores usados}

O Indice de Desenvolvimento Humano foi criado originalmente para medir o nivel de desenvolvimento humano dos paises a partir de indicadores de educaçăo (alfabetizaçăo e taxa de matrícula), longevidade (esperança de vida ao nascer) e renda (PIB per capita). $O$ índice varia de 0 (nenhum desenvolvimento humano) a 1 (desenvolvimento humano total). Paises com IDH até 0,499 tém desenvolvimento humano considerado baixo; os paises com indices entre 0,500 e 0,799 săo considerados de médio desenvolvimento humano; países com IDH maior que 0,800 têm desenvolvimento humano considerado alto.

Para aferir o nível de desenvolvimento humano de municípios as dimensóes são as mesmas - educaçăo, longevidade e renda -, mas alguns dos indicadores usados săo diferentes. Embora meçam os mesmos fenómenos, os indicadores levados em conta no IDH municipal (IDHM) são mais adequados para avaliar as condiçōes de núcleos sociais menores.

Para a avaliaçăo da dimensão educação, o cálculo do IDH municipal considera dois indicadores, com pesos diferentes: taxa de alfabetização de pessoas acima de 15 anos de idade (com peso dois) e a taxa bruta de freqüência à escola (com peso um). $O$ primeiro indicador é o percentual de pessoas com mais de 15 anos capaz de ler e escrever um bilhete simples (ou seja, adultos alfabetizados). O calendário do Ministério da Educaçăo indica que se a criança năo se atrasar na escola ela completará esse ciclo aos 14 anos de idade, dai a mediçảo do analfabetismo se dar a partir dos 15 anos. O segundo indicador é resultado de uma conta simples: o somatório de pessoas (independentemente da idade) que frequentam os cursos fundamental, secundário e superior é dividido pela populaçăo na faixa etária de 7 a 22 anos da localidade. Estăo tambem incluidos na conta os alunos de cursos supletivos de primeiro e de segundo graus, de classes de aceleraçăo e de pósgraduaçảo universitária. Apenas classes especiais de alfabetizaçăo săo descartadas para efeito do cálculo.

Para a avaliaçăo da dimensăo longevidade, o IDH municipal considera o mesmo indicador do IDH de paises: a esperança de vida ao nascer. Esse indicador mostra o número médio de anos que uma pessoa nascida naquela localidade no ano de referência (no caso, 2000) deve viver. $O$ indicador de longevidade sintetiza as condiçőes de saúde e salubridade daquele local, uma vez que quanto mais mortes houver nas faixas etárias mais precoces, menor será a expectativa de vida observada no local.

Para a avaliaçăo da dimensăo renda, o critério usado é a renda municipal per capita, ou seja, a renda média de cada residente no municipio. Para se chegar a esse valor soma-se a renda de todos os residentes e divide-se o resultado pelo número de pessoas que moram no municipio (inclusive crianças ou pessoas com renda igual a zero). No caso brasileiro, 0 cálculo da renda municipal per capita é feito a partir das respostas ao questionário expandido do Censo - um questionário mais detalhado do que o universal e que é aplicado a uma amostra dos domicilios visitados pelos recenseadores. Os dados colhidos pelo Instituto Brasileiro de Geografia e Estatística (IBGE) através dessa amostra do Censo săo expandidos para o total da populaçăo municipal $e$, entăo, usados para o cáculo da dimensăo renda do IDH-M.

Uma vez escolhidos os indicadores, sảo calculados os índices especificos de cada uma das tres dimensōes analisadas: IDHM-E, para educação; IDHM-L, para saúde (ou longevidade); IDHM-R, para renda. Para tanto, sảo determinados os valores de referéncia mínimo e máximo de cada categoria, que seráo equivalentes a 0 e 1, respectivamente, no calculo do indice. Os sub-índices de cada municipio serăo valores proporcionais dentro dessa escala: quanto melhor o desempenho municipal naquela dimensăo, mais próximo o seu índice estará de 1. O IDHM de cada município é fruto da média aritmética simples desses trés sub-indices: somam-se os valores e divide-se o resultado por trés (IDHM-E + IDHM-L + IDHM-R / 3). 


\section{DIMENSÅO EDUCAÇÃO}

Para medir o acesso à educaçăo da populaçăo de uma localidade, o IDH municipal considera dois indicadores: a porcentagem de pessoas alfabetizadas entre os moradores com mais de 15 anos de idade daquele lugar (com peso dois no cálculo final) e a taxa de freqüéncia bruta a salas de aula (peso um).

Para medir o acesso à educaçåo em grandes sociedades, como um país, a taxa de matrícula nos diversos niveis do sistema educacional é um indicador suficientemente preciso. Quando o foco está em núcleos sociais menores, como municípios, esse indicador é menos eficaz, pois os estudantes podem morar em uma cidade e estudar em outra, distorcendo as taxas de matrícula. Daí a opção pelo indicador de frequéncia à sala de aula, que é baseado em dados censitários. O que se pretende aferir é a parcela da populaçăo daquela cidade que vai à escola em comparação à populaçåo municipal em idade escolar.

Pelo calendário do Ministério da Educaçăo, aos 7 anos uma criança deve iniciar o primeiro ciclo do ensino fundamental. Aos 15 anos, o jovem deve ingressar na primeira série do ensino médio, e, aos 22 anos, concluir o ensino superior. Esse calendário indica que a maioria da populaçăo deveria estar envolvida no processo de aprendizado entre as idades de 7 e 22 anos. Por isso, ao se avaliar o acesso das pessoas ao conhecimento, divide-se 0 total de alunos nos três niveis de ensino pela população total dessa faixa etária. A esse indicador se dá o nome de taxa bruta de frequência escolar.

O outro critério para a avaliaçăo da educaçăo de uma populaçăo é o percentual de alfabetizados maiores de 15 anos. Ele se baseia no direito constitucional de todos os brasileiros de terem acesso aos oito séries do ensino fundamental. Ao final desse período, que, pelo calendário normal se encerraria aos 14 anos de idade, espera-se que o individuo seja capaz de ler e escrever um bilhete simples. Dai a opçåo por se medir essa capacidade na populaçăo com 15 anos de idade ou mais. A taxa de alfabetizaçăo é obtida pela divisăo do total de alfabetizados maiores de 15 anos pela população total de mais de 15 anos de idade do município pesquisado.

Se considerarmos que as taxas de alfabetizaçăo e de frequếncia já variam entre 0 e 1 (0\% a $100 \%)$, toma-se desnecessário "converte-las" em um indice, como nas dimensóes saúde e renda. É preciso apenas aplicar os pesos de cada indicador para se chegar a uma média.

Se o municipio em questăo tem uma taxa bruta de frequéncia à escola igual a $85 \%$ e uma taxa de alfabetizaçáo de $91 \%$, o cálculo será assim:

$[0,85+(2 \times 0,91)] / 3 \Rightarrow(0,85+1,82) / 3=2,67 / 3=0,89$.

Logo, o IDHM-E do municlpio será 0,89 .

\section{DIMENSÃO LONGEVIDADE}

Para avaliar o desenvolvimento humano no que diz respeito à longevidade o IDH nacional e - IDH municipal usam a esperança de vida ao nascer. Esse indicador mostra qual a média de anos que a população nascida naquela localidade no ano de referéncia (2000) deve viver - desde que as condiçס̋es de mortalidade existentes se mantenham constantes. Quanto menor for a mortalidade registrada em um municipio, maior será a esperança de vida ao nascer. $O$ indicador é uma boa forma de avaliar as condiçóes sociais, de saúde e de salubridade por considerar as taxas de mortalidade das diferentes faixas etárias daquela localidade. Todas as causas de morte sảo contempladas para chegar ao indicador, tanto as ocorridas em funçăo de doenças quanto as provocadas por causas extemas (violéncias e acidentes).

O Censo 2000 é a base de cálculo de todo o IDH municipal. Para se chegar ao número médio de anos que uma pessoa vive a partir de seu nascimento săo utilizados os dados do questionário expandido do Censo. O resultado dessa amostra é expandido para o restante da populaçăo daquele município.

O cálculo da esperança de vida ao nascer é complexo e envolve várias fases. No caso da esperança de vida por municipio, as estatisticas do registro civil são inadequadas. Por isso, para o cálculo do IDH municipal optou-se por técnicas indiretas para se chegar às estimativas de mortalidade. A base são as perguntas do Censo sobre o número de filhos 
nascidos vivos e o número de filhos ainda vivos na data em que o Censo foi feito. A partir daí såo calculadas proporções de óbitos. Aplica-se, entăo, uma equaçăo que transforma essas proporçőes em probabilidade de morte. A próxima etapa é transformar essas probabilidades em tábuas de vida, de onde é extraída a esperança de vida ao nascer.

Para transformar esse número de anos em um índice, usa-se como parámetro máximo de longevidade, 85 anos, e, como parâmetro mínimo, 25 anos. Assim, se o municipio em queståo tem uma esperança de vida ao nascer de 70 anos, seu IDHM-L será:

$(70-25) /(85-25)=>45 / 60 \Rightarrow$ IDHM-L $=0,750$.

Logo, o IDHM-L do município será 0,750 .

\section{DIMENSÃO RENDA}

O Produto Interno Bruto (PIB) de um pais é o valor agregado na produção de todos os bens e serviços ao longo de um ano dentro de suas fronteiras. O PIB per capita é a divisăo desse valor pela população do país. Trata-se de um indicador eficaz para a avaliação da renda de um universo amplo, como países e unidades da Federaçăo. Esse é o critério usado pelo Pnud mundialmente para o cálculo do IDH-R dos paises e dos Estados.

$\mathrm{Na}$ avaliaçåo da renda dos habitantes de um municipio, o uso do PIB per capita torna-se inadequado. Por exemplo: nem toda a renda produzida dentro da área do município é apropriada pela população residente. A alternativa adotada é o cálculo da renda municipal per capita. Ela permite, por exemplo, uma desagregaçăo por cor ou gênero da populaçăo, o que seria inviável de outra maneira.

A renda média municipal per capita indica a renda média dos individuos residentes no municipio expressa em reais, pela cotação do dia 1 agosto de 2000 . Os valores são extraídos do questionário da amostra do Censo. A partir da pesquisa do IBGE soma-se todo tipo de renda obtida pelos moradores daquele município (inclusive salários, pensőes, aposentadorias e transferências governamentais, entre outros). E a somatória é divida pelo número total de habitantes do municipio. O resultado é a renda municipal per capita.

Para transformar a renda municipal per capita em um índice é feito uma série de cálculos. Primeiro convertem-se os valores anuais máximo e mínimo expressos em dólar PPC (Paridade do Poder de Compra), adotados nos relatórios internacionais do Pnud (US\$ PPC $40.000,00$ e US\$ PPC 100,00, respectivamente), em valores mensais expressos em reais: R\$ $1.560,17$ e R\$ 3,90 .

Em seguida, são calculados os logaritmos da renda média municipal per capita e dos limites máximo e mínimo de referência. O logaritmo é usado porque ele expressa melhor o fato de que um acréscimo de renda para os mais pobres é proporcionalmente mais relevante do que para os mais ricos. Ou seja: R\$ 10,00 a mais por mès para quem ganha $R \$ 100,00$ proporciona um maior retomo em bem-estar do que R\$10,00 para quem ganha $R \$$ $10.000,00$

Finalmente, para se chegar ao indice de renda municipal (IDHM-R) aplica-se a fórmula a seguir: IDH-R = (log de renda média municipal per capita - log do valor de referéncia minimo) / (log do valor de referência máximo - log do valor de referência mínimo). Para um município com renda municipal per capita de R\$ 827,35, o cálculo ficaria assim:

IDHM-R = $(\log R \$ 827,35-\log R \$ 3,90) /(\log R \$ 1.560,17-\log R \$ 3,90) \Rightarrow \operatorname{lDHM}-\mathrm{R}=$ 0,894 .

Fonte: UNESCO/PNUD, 2003 


\section{Anexo 4 IDH}

Indice de Desenvolvimento Humano segundo Regiōes Metropolitanas

\begin{tabular}{|c|c|c|c|c|c|c|}
\hline Requáo Metropolitana & IDHM 91 & Rank 91 & IDHM 00 & Rank 00 & Cres. Relativo & Posicbes \\
\hline \begin{tabular}{|l}
$\begin{array}{l}\text { Núcleo Metropolitano da } \\
\text { Florianopolis }\end{array}$ \\
\end{tabular} & 0,801 & 2 & 0,859 & 1 & $7,2 \%$ & 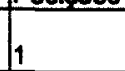 \\
\hline \begin{tabular}{|l|l} 
Núcleo Metropolitano da & RM \\
Norte/Nordeste Catarinense
\end{tabular} & 0.776 & 7 & 0,853 & 2 & $9,9 \%$ & 5 \\
\hline $\begin{array}{l}\text { Núcleo Metropolitano da RM Vale } \\
\text { do Itajai }\end{array}$ & 0,802 & 1 & 0,850 & 3 & $6,0 \%$ & -2 \\
\hline Campinas & 0,788 & 4 & 0,835 & 4 & $6,0 \%$ & 0 \\
\hline \begin{tabular}{|l}
$\begin{array}{l}\text { Núcleo Metropolitano da } \\
\text { Tubaráo }\end{array}$ \\
\end{tabular} & 0,778 & 6 & 0,835 & 5 & $7,3 \%$ & 1 \\
\hline Porto Alegre & 0,782 & 5 & 0,833 & 6 & $6,6 \%$ & -1 \\
\hline Saso Paulo & 0,792 & 3 & 0,828 & 7 & $4,5 \%$ & -4 \\
\hline $\begin{array}{l}\text { Area de Expansáo Metroplitana da } \\
\text { RM Vale do Itajal }\end{array}$ & 0,758 & 11 & 0,826 & 8 & $8,9 \%$ & 3 \\
\hline $\begin{array}{l}\text { Area de Expansåo Metropolitana } \\
\text { da RM Carbonifera } \\
\end{array}$ & 0,737 & 20 & 0,824 & 9 & $11,7 \%$ & 11 \\
\hline Curitiba & 0,763 & 10 & 0,824 & 10 & $8.0 \%$ & 0 \\
\hline $\begin{array}{l}\text { Area de Expansăo Metropolitana } \\
\text { da RM Foz do Rio Itajai }\end{array}$ & 0,719 & 26 & 0,820 & 11 & $14,0 \%$ & 15 \\
\hline Maringá & 0,738 & 19 & 0,817 & 12 & $10,7 \%$ & 7 \\
\hline Baixada Santista & 0.773 & 8 & 0,817 & 13 & $5,7 \%$ & -5 \\
\hline $\begin{array}{l}\text { Area de Expansáo Metropolitana } \\
\text { da } \quad \text { RM N Norte/Nordeste } \\
\text { Catarinense }\end{array}$ & 0,749 & 17 & 0,816 & 14 & $9.0 \%$ & 3 \\
\hline Rio de Janeiro & 0,764 & 9 & 0,816 & 15 & $6,8 \%$ & -6 \\
\hline Londrina & 0,747 & 18 & 0,813 & 16 & $8,8 \%$ & 2 \\
\hline $\begin{array}{l}\begin{array}{l}\text { Núcleo Metropolitano da RM } \\
\text { Carbonifera }\end{array} \\
\end{array}$ & 0,753 & 15 & 0,813 & 17 & $7,9 \%$ & -2 \\
\hline Goiania & 0,754 & 14 & 0,812 & 18 & $7,7 \%$ & -4 \\
\hline $\begin{array}{l}\text { Núcleo Metropolitano da RM Foz } \\
\text { do Rio ltajai }\end{array}$ & 0,751 & 16 & 0,812 & 19 & $8,2 \%$ & -3 \\
\hline Belo Horizonte & 0,757 & 12 & 0,811 & 20 & $7,1 \%$ & -8 \\
\hline $\begin{array}{l}\text { Area de Expansáo Metropolitana } \\
\text { da RM Tubarao }\end{array}$ & 0,729 & 24 & 0.806 & 21 & $10,6 \%$ & 3 \\
\hline Vale do Aco & 0,733 & 22 & 0,803 & 22 & $9,5 \%$ & 0 \\
\hline $\begin{array}{l}\text { Area de Expansáo Metropolitana } \\
\text { da RM Florianópolis }\end{array}$ & 0,719 & 27 & 0,802 & 23 & $11,5 \%$ & 4 \\
\hline Grande Vitória & 0,730 & 23 & 0,798 & 24 & $9,4 \%$ & -1 \\
\hline Belém & 0,755 & 13 & 0,797 & 25 & $5,5 \%$ & -12 \\
\hline Salvador & 0,735 & 21 & 0,794 & 26 & $7,9 \%$ & -5 \\
\hline $\begin{array}{l}\begin{array}{l}\text { Colar Metropolitano da RM Belo } \\
\text { Horizonte }\end{array} \\
\end{array}$ & 0,724 & 25 & 0,792 & 27 & $9,4 \%$ & -2 \\
\hline Recife & 0,715 & 28 & 0,780 & 28 & $9,0 \%$ & 0 \\
\hline Fortaleza & 0,688 & 31 & 0,767 & 29 & $11,5 \%$ & 2 \\
\hline Grande Săo Luis & 0,707 & 29 & 0,766 & 30 & $8,4 \%$ & -1 \\
\hline Natal & 0,689 & 30 & 0,762 & 31 & $10,6 \%$ & -1 \\
\hline Maceio & 0,660 & 32 & 0,724 & 32 & $9,7 \%$ & 0 \\
\hline $\begin{array}{l}\text { Colar Metropolitano da RM Vale do } \\
\text { Aço }\end{array}$ & 0,601 & 33 & 0,687 & 33 & $14,3 \%$ & 10 \\
\hline
\end{tabular}

Fonte: UNESCO/PNUD 


\section{Anexo 5 AlH}

Tabela 1: Número de internações da população e grupo de 15 a 49 anos por Região Metropolitana. 2002.

\begin{tabular}{lrr}
\hline Regióes Motropolitanas & Total & $\mathbf{1 5 - 4 9}$ \\
\hline N/NE de Santa Catarina & 24269 & 13761 \\
Campinas & 137367 & 75315 \\
Porto Alegre & 268966 & 133415 \\
Sảo Luis & 85633 & 54467 \\
Maceió & 83510 & 44256 \\
Colar Metropolitano do Vale do Aço & 11982 & 5904 \\
\hline
\end{tabular}

Fonte: MS/SAS/DATASUS, 2002. 


\section{Anexo 6 Diagnóstico}

Tabela 2: AlHs de tipo 1 segundo sexo, diagnóstico e Regióes Metropolitanas. 2002

continua

\begin{tabular}{|c|c|c|c|c|c|c|c|c|c|}
\hline \multirow{3}{*}{ Diag CID10 } & \multicolumn{3}{|c|}{ RM Campinas } & \multicolumn{3}{|c|}{ Colar V. Aço } & \multicolumn{3}{|c|}{ RM Maceió } \\
\hline & \multicolumn{2}{|c|}{ Taxa /100.000 } & \multirow{2}{*}{ Valor-p } & \multicolumn{2}{|c|}{ Taxa $/ 100.000$} & \multirow{2}{*}{ Valor-p } & \multicolumn{2}{|c|}{ Taxa $/ 100.000$} & \multirow{2}{*}{ Valor-p } \\
\hline & Masc. & Fem. & & Masc. & Fem. & & Masc. & Fem. & \\
\hline - Algumas doenças infecciosas e parasitárias & 313 & 236 & 0,000 & 203 & 303 & 0.004 & 221 & 112 & 0,000 \\
\hline II. Neoplasias (tumores) & 162 & 314 & 0,000 & 106 & 344 & 0,000 & 161 & 618 & 0,000 \\
\hline III. Doenças sangue órgåos hemat e transt imunitár & 33 & 33 & 0,859 & 35 & 60 & 0.100 & 10 & 16 & 0,052 \\
\hline IV. Doenças endócrinas nutricionais e metabólicas & 51 & 84 & 0,000 & 172 & 224 & 0,092 & 52 & 64 & 0,070 \\
\hline V. Transtornos mentais e comportamentais & 485 & 208 & 0,000 & 179 & 92 & 0.001 & 930 & 347 & 0,000 \\
\hline VI. Doenças do sistema nervoso & 70 & 54 & 0,000 & 137 & 106 & 0,199 & 40 & 34 & 0,231 \\
\hline VII. Doenças do olho e anexos & 11 & 6 & 0,001 & 12 & 7 & 0,497 & 26 & 30 & 0,361 \\
\hline Vill.Doenças do ouvido e da apófise mastoide & 11 & 13 & 0,500 & 5 & 2 & 0,575 & 1 & 2 & 0,199 \\
\hline IX. Doenças do aparelho circulatório & 232 & 223 & 0,233 & 347 & 410 & 0,090 & 228 & 218 & 0,422 \\
\hline X. Doenças do aparelho respiratório & 222 & 164 & 0,000 & 318 & 325 & 0,863 & 177 & 124 & 0,000 \\
\hline XI. Doenças do aparelho digestivo & 416 & 345 & 0,000 & 613 & 494 & 0,020 & 449 & 454 & 0,811 \\
\hline XII. Doenças da pele e do tecido subcutâneo & 68 & 42 & 0,000 & 73 & 43 & 0,074 & 27 & 29 & 0,610 \\
\hline XIII.Doenças sist osteomuscular e tec conjuntivo & 159 & 96 & 0,000 & 255 & 166 & 0,005 & 134 & 95 & 0,000 \\
\hline XIV. Doenças do aparelho geniturinário & 144 & 597 & 0,000 & 285 & 848 & 0,000 & 133 & 1092 & 0,000 \\
\hline XVI. Algumas afec originadas no periodo perinatal & 0 & 1 & 0,020 & 0 & 0 & & 0 & 9 & 0,000 \\
\hline XVII.Malf cong deformid e anomalias cromossômicas & 18 & 18 & 0,853 & 14 & 14 & 0,971 & 12 & 35 & 0,000 \\
\hline XVIII.Sint sinais e achad anorm ex clin e laborat & 101 & 166 & 0,000 & 78 & 70 & 0,670 & 21 & 40 & 0,000 \\
\hline XIX. Lesőes enven e alg out conseq causas externas & 602 & 186 & 0.000 & 741 & 207 & 0,000 & 608 & 164 & 0,000 \\
\hline XX. Causas externas de morbidade e mortalidade & 30 & 8 & 0.000 & $\theta$ & 10 & 0,976 & 6 & 3 & 0,137 \\
\hline XXI. Contatos com serviços de saúde & 71 & 192 & 0,000 & 42 & 17 & 0,031 & 19 & 13 & 0,089 \\
\hline Total & 3196 & 2982 & 0,000 & 3625 & 3752 & 0,328 & 3254 & 3497 & 0,000 \\
\hline
\end{tabular}


Tabela 2: AlHs de tipo 1 segundo sexo, diagnóstico e Regiōes Metropolitanas. 2002

\begin{tabular}{|c|c|c|c|c|c|c|c|c|c|}
\hline \multirow{3}{*}{ Diag CID10 } & \multicolumn{3}{|c|}{ RMP Alegre } & \multicolumn{3}{|c|}{ RM S Luis } & \multicolumn{3}{|c|}{ NINE Sta Cat-núcleo } \\
\hline & \multicolumn{2}{|c|}{ Taxa /100.000 } & \multirow{2}{*}{ Valor-p } & \multicolumn{2}{|c|}{ Taxa $/ 100.000$} & \multirow{2}{*}{ Valor-p } & \multicolumn{2}{|c|}{ Taxa $/ 100.000$} & \multirow{2}{*}{ Valor-p } \\
\hline & Masc. & Fem. & & Masc. & Fem. & & Masc. & Fem. & \\
\hline Algumas doenças infecciosas e parasitárias & 371 & 346 & 0,002 & 221 & 196 & 0,026 & 207 & 187 & 0,243 \\
\hline II. Neoplasias (tumores) & 200 & 489 & 0,000 & 294 & 720 & 0,000 & 237 & 491 & 0,000 \\
\hline III. Doenças sangue órgăos hemat e transt imunitár & 22 & 36 & 0,000 & 34 & 50 & 0,002 & 14 & 26 & 0.022 \\
\hline IV. Doenças endócrinas nutricionais e metabólicas & 75 & 116 & 0,000 & 58 & 61 & 0,712 & 32 & 181 & 0,000 \\
\hline V. Transtomos mentais e comportamentais & 272 & 181 & 0.000 & 568 & 225 & 0,000 & 294 & 137 & 0,000 \\
\hline VI. Doenças do sistema nervoso & 105 & 86 & 0,000 & 101 & B2 & 0,000 & 113 & 70 & 0,000 \\
\hline VII. Doenças do olho e anexos & 6 & 4 & 0,057 & 6 & 3 & 0,136 & 12 & 8 & 0,335 \\
\hline VIII.Doenças do ouvido e da apófise mastóide & 10 & 10 & 0,582 & 2 & 2 & 0,963 & 1 & 4 & 0,157 \\
\hline IX. Doenças do aparelho circulatório & 317 & 341 & 0,002 & 216 & 534 & 0,000 & 162 & 362 & 0,000 \\
\hline X. Doenças do aparelho respiratório & 380 & 310 & 0.000 & 155 & 128 & 0,004 & 202 & 136 & 0,000 \\
\hline XI. Doenças do aparelho digestivo & 500 & 470 & 0.002 & 538 & 641 & 0,000 & 386 & 293 & 0,000 \\
\hline XII. Doenças da pele e do tecido subcutâneo & 73 & 56 & 0,000 & 128 & 68 & 0,000 & 36 & 27 & 0,162 \\
\hline XIII.Doenças sist osteomuscular e tec conjuntivo & 174 & 103 & 0,000 & 230 & 104 & 0,000 & 278 & 124 & 0,000 \\
\hline XIV. Doenças do aparelho geniturinário & 166 & 601 & 0,000 & 196 & 1063 & 0,000 & 121 & 401 & 0,000 \\
\hline XVI. Algumas afec originadas no periodo perinatal & 0 & 1 & 0,148 & 1 & 0 & 0.149 & 1 & 0 & 0,317 \\
\hline XVII.Malf cong deformid e anomalias cromossomicas & 13 & 17 & 0,017 & 42 & 163 & 0,000 & 25 & 32 & 0,259 \\
\hline XVIII.Sint sinais e achad anorm ex clin e laborat & 68 & 93 & 0,000 & 131 & 194 & 0,000 & 17 & 44 & 0.000 \\
\hline XIX. Lesర̄es enven e alg out conseq causas externas & 677 & 178 & 0,000 & 1196 & 295 & 0,000 & 560 & 168 & 0,000 \\
\hline XX. Causas externas de morbidade e mortalidade & 92 & 22 & 0,000 & 74 & 23 & 0,000 & 1 & 0 & 0,317 \\
\hline XXI. Contatos com serviços de saúde & 82 & 136 & 0,000 & 159 & 74 & 0,000 & 52 & 68 & 0,074 \\
\hline Total & 3603 & 3596 & 0,783 & 4350 & 4607 & 0,000 & 2751 & 2760 & 0,884 \\
\hline
\end{tabular}

Fonte: MS/SAS/DATASUS, 2002

- Foram excluidos: Gravidez, Parto e Puerpério (XV), Algumas Afeccőes originadas no periodo perinatal (XVI) e Malformaçøes congenitas, deformidades e anomalias cromossomicas (XVII). 
Anexo 7 Causas Externas

Tabela 3: Principais Causas Externas de internaçăo* por sexo. Regišo Metropolitana, 2002. (por 100.000)

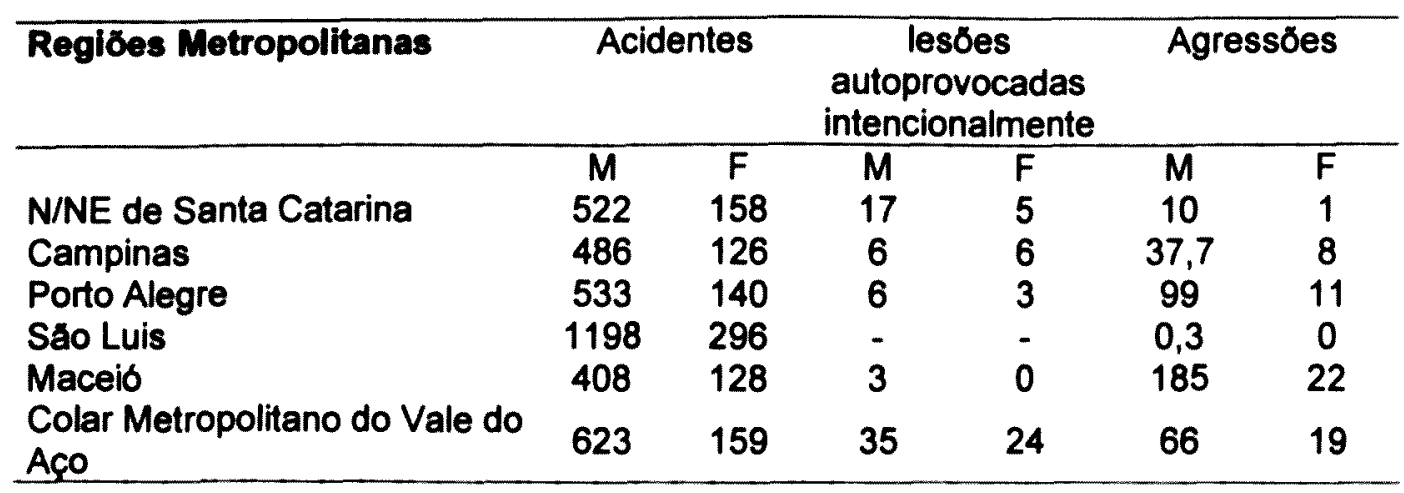

Fonte: MSISASIDATASUS, 2002

-Para o cálculo desta laxa usamos a variável "diagnóstico secundário". 